Universidade de Brasília

Instituto de Biologia

Departamento de Biologia Celular

Programa de Pós-Graduação em Biologia Molecular

\title{
Produção de hemicelulases recombinantes e aplicação na hidrólise do bagaço de cana-de-açúcar
}

Lorena Cardoso Cintra

Orientador: Cirano José Ulhoa

Coorientadora: Fabrícia Paula de Faria

Brasília, DF 


\title{
Produção de hemicelulases recombinantes e aplicação na hidrólise do bagaço de cana-de-açúcar
}

\author{
Lorena Cardoso Cintra \\ Orientador: Cirano José Ulhoa \\ Coorientadora: Fabrícia Paula de Faria
}

Tese apresentada ao Programa de PósGraduação em Biologia Molecular da Universidade de Brasília como requisito parcial para obtenção do título de Doutora em Biologia Molecular.

Brasília, DF 
Tese de Doutorado apresentada por Lorena Cardoso Cintra, documento parcial requerido para obtenção do título de Doutor em Biologia Molecular. Este trabalho foi desenvolvido no Laboratório de Biotecnologia de Fungos e Laboratório de Enzimologia da Universidade Federal de Goiás em parceria com o Departamento de Biologia Celular da Universidade de Brasília, sendo intitulado por Produção de hemicelulases recombinantes e aplicação na hidrólise do bagaço de cana-de-açúcar, sob orientação do Prof. Dr. Cirano José Ulhoa e coorientação da Profa. Dra. Fabrícia Paula de Faria

\section{BANCA EXAMINADORA}

1. Prof. Dr. Edivaldo Ximenes F. Filho - Departamento de Biologia Celular/ Universidade de Brasília - Membro Titular (Interno).

2. Profa. Dra. Nádia Skorupa Parachin - Departamento de Biologia Celular/ Universidade de Brasília - Membro Titular (Interno).

3. Prof. Dr. Aldo José Pinheiro Dillon - Instituto de Biotecnologia/ Universidade de Caxias do Sul - Membro Titular (Externo).

4. Prof. Dr. João Ricardo M. de Almeida - Embrapa Agroenergia - Membro Titular (Externo).

5. Prof. Dr. Saulo José Linhares Siqueira - Universidade Estadual de Goiás - Membro Suplente (Externo). 
Dedico àqueles que outrora dedicaram mais a mim do que quatro anos de pesquisa: ao meu companheiro (no sentido amplo da palavra), Renato. Aos meus amados pais e a todos aqueles que acreditam na Pátria Educadora! 


\section{AGRADECIMENTOS}

\section{I've got life \\ I've got lives \\ I've got headaches, and toothaches, And bad times too like you" Ain't Got No / I Got Life (Nina Simone).}

Começo os agradecimentos com um trecho de uma música da maravilhosa Nina Simone, para dizer que aqui reside um humano e que, para além das regras de escrita científica, onde o infinitivo impera, sente a necessidade de dizer EU, NÓS e VÓS! Vamos agradecer, em primeira pessoa, as terceiras pessoas que nos ajudaram. Afinal, isso é fruto de um trabalho coletivo onde, uma palavra de incentivo na hora certa ou mesmo um puxão de orelha, um shaker ou um poço de gel cedido, fizeram toda a diferença. Já expressei os genes, agora às palavras de agradecimento àqueles que foram essenciais para essa realização.

Para começar, eu gostaria de agradecer aos meus orientadores: Profa. Dra. Fabrícia Paula de Faria e Prof. Dr. Cirano José Ulhoa. Há quem diga que ter dois orientadores é azar. Eu digo que foi sorte! A Fabrícia, que me ensinou mais sobre mim, do que EU sonhava em saber. Obrigada pelos ensinamentos e pela oportunidade concedida. Saio com a certeza que aprendi muito com e por você. MUITO OBRIGADA, de coração! Cirano, obrigada pela objetividade na hora certa, pela paciência e por confiar em mim. Você é um exemplo. Obrigada também a todos do laboratório de enzimologia da UFG, em especial, a Aline, Cristine, Amanda Rafaella e a Marcela.

À minha eterna orientadora de longa data, Rosália. Já se foram 11 anos desde a iniciação e você me acompanhou até aqui. Esse doutorado chegou a final graças a você. Obrigada por tudo! Aos meus ilustríssimos amigos do Laboratório de Biotecnologia de Fungos da UFG, que dividiram comigo grande parte do meu dia (ou noite). Amanda, minha companheira de estrada BSB-GYN/GYN-BSB e de discussões científicas ou nem tanto. Atenda o seu telefone e responda o whatsapp, é uma súplica! Também gostaria de agradecer os meus queridos Léo, Douglas, Alexander e Isabele: vocês são meu orgulho, mestres mesmo que ainda na iniciação científica, a prova de que esse Bréésil tem futuro.

Ao Saulo, espero um dia poder chegar um "tiquim" perto do que você é como pessoa e profissional. Como pode caber tanto conhecimento e humildade em uma pessoa só? Obrigada por tudo, viu! Francieli, quero muito te agradecer, mas primeiro agradeço ao Paulo, por ter nascido nesse Goiás véi sem porteira e ter te trazido para cá. Afinal, se 
não fosse assim, qual seria o motivo de trocar Chopinzinho por Goiânia? Você chegou na hora certa. Muito obrigada! Syd, já disse que o amor e o ódio andam lado a lado, rs, mas o amor sempre prevalece. Ilítia, minha querida, sempre pronta para ajudar e para ser ajudada, obrigada! Agora você já pode voar, já que conhece o caminho p zoropas.

Iza, tenho muito a te agradecer por 4 anos de help tecnológico, e, principalmente, pelo help nessa reta final. As palavras não serão suficientes para dizer esse obrigada, então: OBRIGADA, sem mais! Carol, minha querida amiga, ACABOUU! É TETRAAA! Obrigada pela parceria profissional e pessoal. Valeu!

Obrigada a todos do Laboratório de Engenharia Genética da UFG. Aos Professores Luiz Arthur, Ivan e Guilherme, além das queridas Aline e Juliana.

Ao meu chefe/amigo - amigo/chefe: Luiz Augusto. Tenho muita certeza que não teria conseguido sem você. Foi o melhor conselheiro/psicólogo que poderia ter. Obrigada por ter compartilhado da sua experiência de vida comigo (coisa de quem já viveu muito, rs) e me ajudado a superar esse desafio. Trabalhar e ser doutoranda só foi possível por você e com você. Obrigada por ter me respeitado desde o início quando cheguei com esse little problem para ser resolvido. Não é atoa que você é boss.

À minha querida Veridiana, OBRIGADA maiúsculo. Obrigada pelo apoio em forma de incentivo ou puxão de orelha. Você é um exemplo de profissional que deve ser copiado. Obrigada pela paciência, sabemos como é difícil para você, rs. E por fim, obrigada pela amizade, a parte mais valiosa de todas. Rogério, obrigada por todos os galhos quebrados e pela amizade.

Às minhas queridas Ana Paula, Regiane e Moema, gostaria de estender os agradecimentos que fiz ao Prof. Luiz e à Veri a vocês três. Obrigada pela amizade e compreensão enorme da minha dificuldade em estar $100 \%$ na patologia. Eric, Estela, Paula e Mariana, meus amigos que estiveram sempre próximos a mim, ouvindo o clássico: "Porque quando eu terminar o doutorado eu vou....". Espero agora poder ir...de fato! Um obrigada GRANDE corado por Tricômio de Masson para vocês. Gostaria de agradecer também ao Prof. Café e ao Adilson, Prof. Eugênio, Danilo, Rafael e a todos do Setor de Patologia (EVZ/UFG). Obrigada por me fazerem amar esse trabalho a cada dia que passa. Compartilho a felicidade desse título com vocês.

Obrigada à bonitinha Alice e ao Jota, meus amigos amados, pelas sopas e cafés com carinho e por cuidar do Renato também. Obrigada aos meus amigos que tiveram que ouvir muito "Não posso": Rodolfo, meu irmão escolhido, Jacque e Rosa, Nayara, Carol, Fred, Lorena, Bruno, Marina. Aos amigos do \#dominGOT Regiane, Pablo, Jordana, 
Celso, Pedro, Paulo. Obrigada em especial à minha amiga Amanda Araújo, afinal, foram quatro anos de estrada e auxílios com tudo de burocrático que envolveu a UnB, além daquele ouvido sempre pronto para discutir um protocolo ou uma lamentação.

Obrigada à Ana, nossa querida secretária da pós-graduação, por ser sempre muito prestativa e simpática comigo. A FAPDF e a pós-graduação (BioMol UnB) pela concessão de apoio financeiro, sempre que necessário, para participação de cursos e congressos. À Petrobrás pelo apoio financeiro para execução do projeto e à UFG pela bolsa concedida (Pró-qualificar).

Conceição, OBRIGADA, OBRIGADA, OBRIGADA por cuidar da gente. Você foi uma mãe para mim, e melhor, ainda é!

Um obrigada mais que especial à minha família (irmão, cunhados e cunhadas, sobrinhos e sobrinhas, vóvs e sogrinha...). Aos meus amados pais, aquele super obrigada! Afinal, vocês me permitiram escolher lááá atrás o estudo em primeiro lugar. Vocês são a minha Pátria Educadora.

Ao meu marido/amigo/companheiro/namorado/bridgeovertroubledwater: Renato. Segurando as pontas desde 2000... Agora provou que não tá de brinks, néh noum? OBRIGADA! Você foi meu braço direito e esquerdo, olhos e ouvidos, boca e sentidos (acho que copiei ou fiz uma música sem querer). Eu não poderia te agradecer sem usar de Clarice, a Lispector: "Escuta, eu te deixo ser, deixa-me ser então". E você deixou e deixa. Eu tenho sorte de ter você. Finalizo o meu agradecimento a você, por intermédio de Simone de Beauvoir: "Todas as vitórias ocultam uma abdicação”.

E por fim, eu acredito que é possível mudar um país por meio da educação. Eu acredito na educação como transformadora de realidades. Eu acredito em uma Pátria Educadora e espero estar contribuindo um pouquinho - que seja - para a ciência feita em nosso país. 


\section{ÍNDICE}

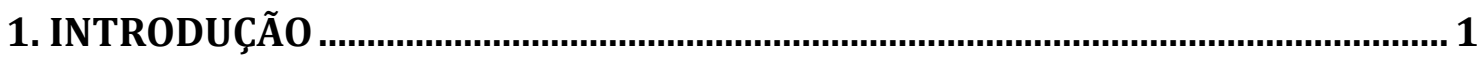

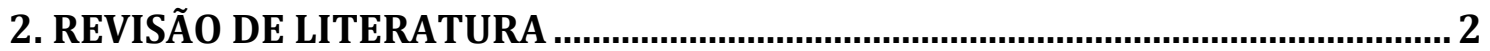

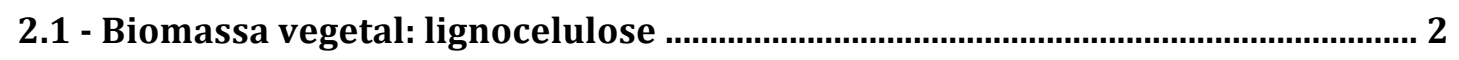

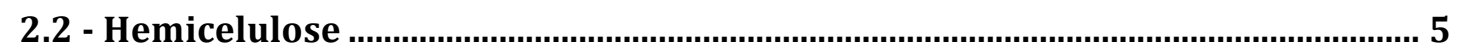

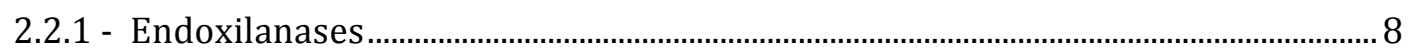

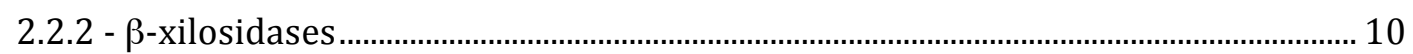

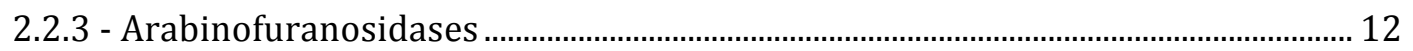

2.3 - Produção de hemicelulases em Pichia pastoris........................................................ 14

2.4 - Fungos filamentosos produtores de hemicelulases ................................................ 19

2.4.1 - Humicola grisea var. thermoidea …………….......................................................... 20

2.4 .2 - Penicillium purpurogenum …………………............................................................. 22

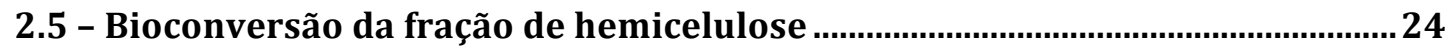

3. OBJETIVOS

4. MATERIAL

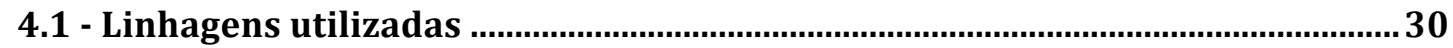

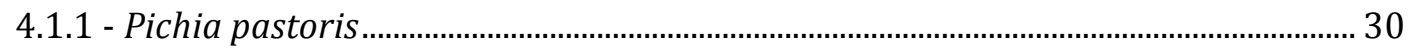

4.1.2 - Humicola grisea ………………………………................................................... 30

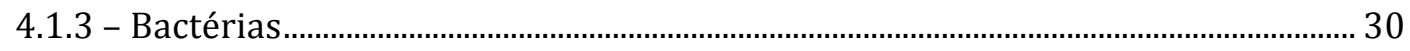

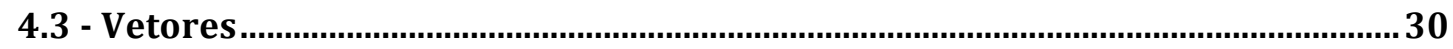

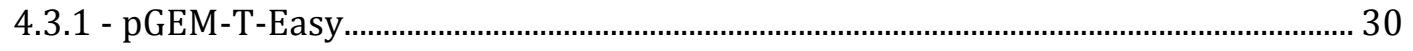

4.3.2 - pHIL-D2 e pPIC9 …………..................................................................................... 31

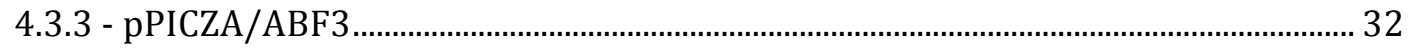

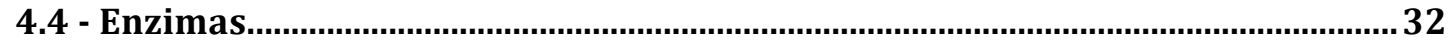

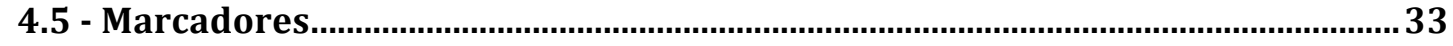

4.6 - Kits de Uso Específico em Biologia Molecular …...................................................... 33

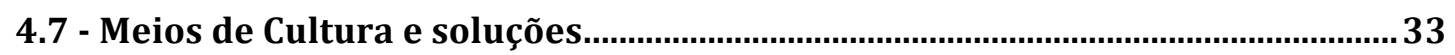

4.7.1 - Meios para Cultivo de Bactérias ...................................................................................... 33

4.7.2 - Meios para Cultivo da Levedura P. pastoris e Soluções Estoque ............................ 34

4.7.3 - Meios para Cultivo do Fungo H. grisea ………………………………….................... 36

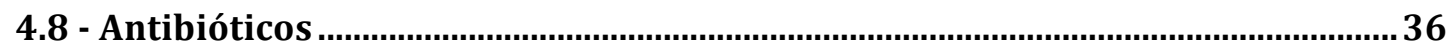

4.9 - Determinação da Atividade Celulolítica e Xilanolítica ………………………….......36

4.10 - Soluções para eletroforese em gel de agarose

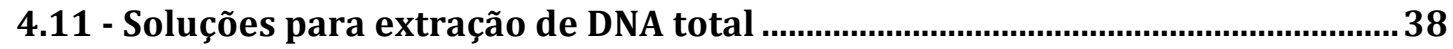


4.12 - Soluções para análise de proteínas em gel de Poliacrilamida Desnaturante

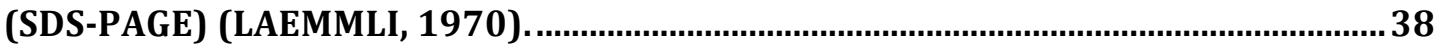

Revelação das proteínas por coloração do gel com Azul de Comassie......................... 40

4.13 - Substratos empregados como fonte de carbono ……..........................................40

4.14 - Preparo da medula da cana-de-açúcar..................................................................... 41

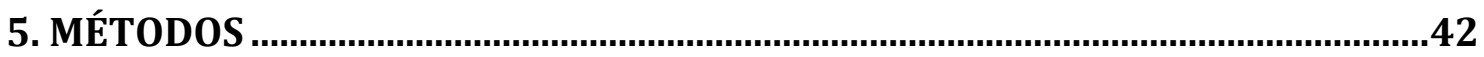

5.1 - Cultivo e manutenção de micro-organismos .......................................................... 42

5.2- Produção de $\alpha$-L-arabinofuranosidase e $\beta$-xilosidases por $H$. grisea $\ldots$................. 42

5.3 - Dosagem da atividade xilanolítica pelo Método de DNS ......................................... 42

5.4 - Dosagem da atividade de Arabinofuranosidase e $\beta$-xilosidase ............................ 43

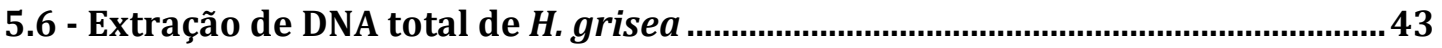

5.7 - Extração de RNA total de H. grisea …..................................................................44

5.8 - Eletroforese de ácidos nucléicos em gel de agarose ...........................................44

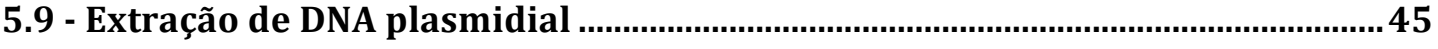

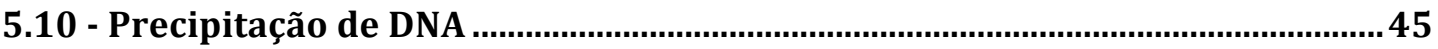

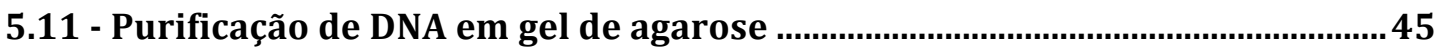

5.12 - Preparação de células bacterianas eletrocompetentes..................................... 45

5.13 - Transformação de E. coli por eletroporação ………….........................................46

5.14 - Desenho dos oligonucleotídeos para amplificação dos genes de $\alpha$-L-

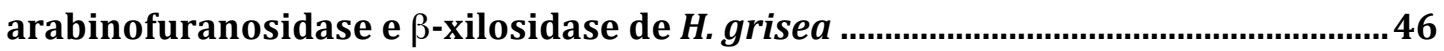

5.15 - Obtenção da primeira fita de cDNA ….............................................................. 47

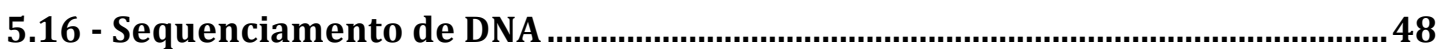

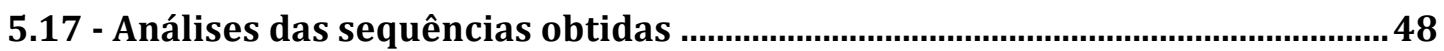

5.18 - Produção de $\alpha$-L-arabinofuranosidase (ABF3) de $P$. purpurogenum por $P$. pastoris.

5.19 - Estratégia para transformação das $\beta$-xilosidases de H. grisea em P. pastoris

5.19.1 - Construção dos vetores 49

5.20 - Preparo de células competentes de P. pastoris

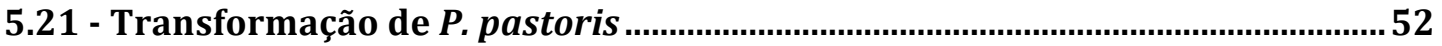

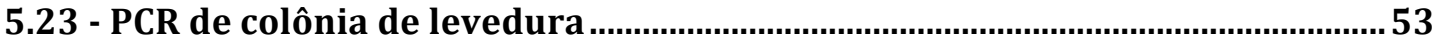

5.23.1 - Extração do DNA da levedura ……………………..................................................... 53

5.23.2 - Reação de PCR …………………………………….................................................... 53

5.24 - Produção das enzimas recombinantes em frasco (adaptado do Manual do Kit de Expressão em P. pastoris). 
5.25 - Otimização da produção de HXYLA por P. pastoris em frasco por meio de planejamento fatorial $2^{3}$.

5.25 - Análise de proteína em gel de poliacrilamida desnaturante (SDS-PAGE).... 56

5.25.1 - Preparo da amostra de sobrenadante de cultura ...................................................... 56

5.25.2 -Condições da eletroforese em gel de poliacrilamida ……………………………..... 56

5.25.3 - Coloração com Coomassie Blue ..................................................................................... 56

5.26 - Zimograma para $\beta$-xilosidase

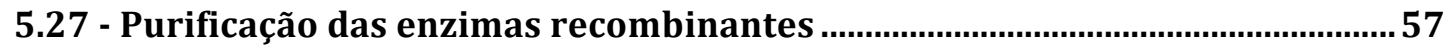

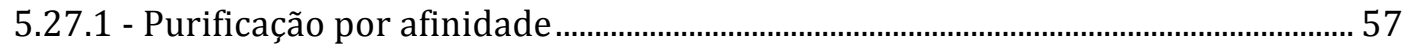

5.27.2 - Purificação por cromatografia por exclusão de tamanho....................................... 57

5.28 - Caracterização bioquímica da enzima recombinante (HXYLA) …………...............5

5.29 - Hidrólise de xilanas comerciais, medula de cana-de-açúcar e BCA pré-

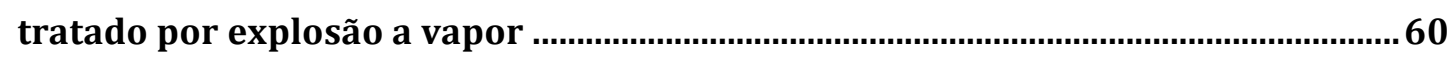

5.29.1 - Hidrólise de xilanas purificadas comerciais e medula de cana-de-açúcar ..... 60

5.29.2 - Hidrólise enzimática do BCA pré-tratado por explosão a vapor para o reaproveitamento da fração de hemicelulose .

5.29.3 - Avaliação da suplementação de celulases comerciais com as hemicelulases recombinantes para hidrólise enzimática do BCA ……………………….............................. 64

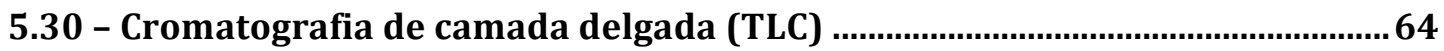

6. RESULTADOS E DISCUSSÃO

6.1 - Produção da endoxilanase 2 (HXYN2) de H. grisea por P. pastoris .................... 66 6.2 - Produção de uma $\alpha$-L-arabinofuranosidase (ABF3) de P. purpurogenum por

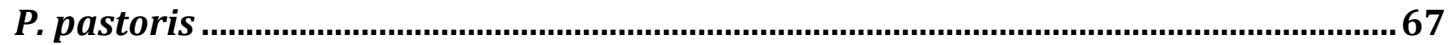

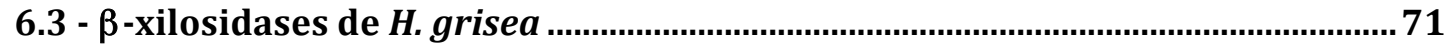

6.3.1 - Análise da produção de $\beta$-xilosidases e $\alpha$-L-arabinofuranosidases por $H$. grisea cultivado em diferentes substratos lignocelulósicos. ............................................................ 71

6.2.2 - Clonagem dos genes de duas $\beta$-xilosidases de H. grisea .......................................... 74

6.2.3 - Expressão dos genes HxylA e HxylB por P. pastoris.................................................... 83

6.2.3.5 - Otimização da produção de HXYLA por P. pastoris por meio de planejamento

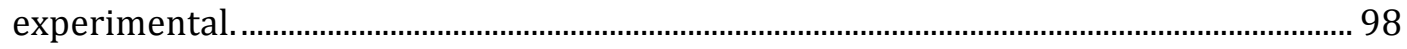

6.2.3.6 - Purificação da enzima recombinante (HXYLA) e Zimograma............................105

6.2.3.7 -Caracterização enzimática da enzima recombinante HXYLA.............................107

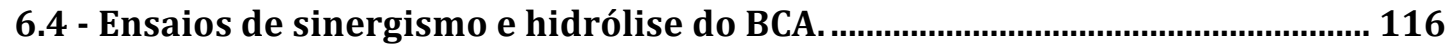

6.4.1 - Avaliação do sinergismo entre HXYN2 e HXYLA na hidrólise da xilana e medula da cana-de-açúcar . 
6.4.2 - Avaliação do sinergismo entre HXYN2 e ABF3 na hidrólise da xilana

6.4.3 - Hidrólise Enzimática do BCA Pré-tratado por explosão a vapor com as hemicelulases recombinantes: ABF3, HXYN2 e HXYLA.

6.4.3 - Avaliação da suplementação do preparado comercial Accellerase®1500

(DuPont) com hemicelulases para hidrólise do BCA.

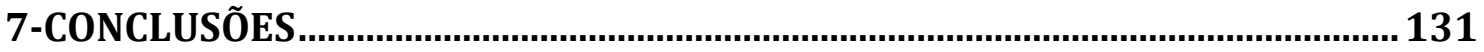

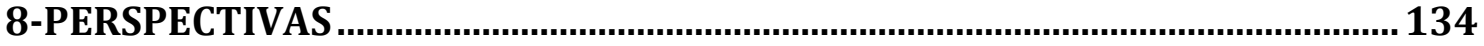

9. REFERÊNCIAS BIBLIOGRÁFICAS 


\section{LISTA DE FIGURAS}

Figura 1 - estrutura da parede celular do bagaço de cana-de-açúcar ou outros resíduos agroindustriais.

Figura 2 - Esquema da composição da xilana e enzimas envolvidas envolvidas na degradação da xilana

Figura 3 - Mecanismos de integração do cassete de expressão no genoma de $P$. pastoris utilizados no presente trabalho.

Figura 4 - Representação esquemática do mapa físico do vetor para clonagem de produto de PCR pGEM-T-Easy (Promega).

Figura 5 - Representação esquemática dos vetores de expressão para $P$. pastoris. 32

Figura 6 - Representação esquemática do mapa físico do vetor pPICZA para expressão em $P$. pastoris e sítio de clonagem para $\mathrm{ABF} 3$ de $P$. purpurogenum.

Figura 7 - Análise do perfil de proteínas secretadas pelo transformante produtor de HXYN2 e da purificação da proteína recombinante.

Figura 8 - Análise em gel de agarose $0,8 \%$ dos produtos da amplificação por PCR de colônia de leveduras dos transformantes $\mathrm{pP} / \mathrm{ABF} / \mathrm{GS}$ e $\mathrm{pP} / \mathrm{ABF} / \mathrm{SM}$.

Figura 9 - Cinética da produção da enzima ABF3 de P. purpurogenum por $P$. pastoris pelos transformantes $\mathrm{pP} / \mathrm{ABF} / \mathrm{GS}$ e $\mathrm{pP} / \mathrm{ABF} / \mathrm{SM}$.

Figura 10 - Perfil eletroforético em gel SDSPAGE 13\% de proteínas secretadas por P. pastoris (pP/ABF/GS).

Figura 11 - Cinética da produção de $\beta$-xilosidases e $\alpha$-L-arabinofuranosidases por $H$. grisea cultivado na presença de BCA e FT..

Figura 12 - Análise eletroforética dos produtos de amplificação dos genes $h x y l A$ e $h x y l B$ de $H$.

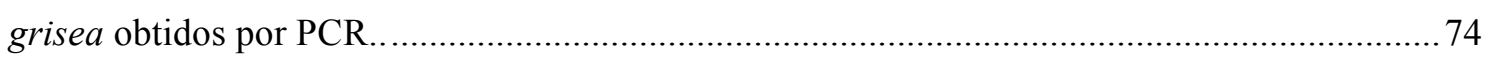

Figura 13 - Estratégia para clonagem dos genes $h x y l A$ e $h x y l B$ no vetor pGEM-T-Easy............75

Figura 14 - Dendograma gerado a partir da sequência de HXYLA de H. grisea e de sequências obtidas por alinhamento pelo BLASTP e construída pelo método de neighbor-joining. . .78 Figura 15 - Dendograma gerado a partir da sequência de HXYLB de H. grisea e de sequências obtidas por alinhamento pelo BLASTP e construída pelo método de neighbor-joining. 79 Figura 16 - Alinhamento entre sequências de aminoácidos de HXYLA de H. grisea com algumas das sequências de enzimas da família GH43 obtidas por busca pelo algorítimo BlastP.

Figura 17 - Alinhamento entre sequências de aminoácidos de HXYLB de H. grisea com algumas das sequências de enzimas da família GH43 obtidas por busca pelo algorítimo BlastP. 
Figura 19 - Análise eletroforética em gel de agarose $0,8 \%$, corado com brometo de etídio, da PCR de colônia dos transformantes obtidos..

Figura 20 - Análise eletroforética em gel de agarose $0,8 \%$, corado com brometo de etídio, do produto da digestão dos vetores pHXYLA, pHXYLB, pPXYLA e pPXYLB.

Figura 21 - Esquema para demonstração das estratégias utilizadas para linearizar os vetores para transformação de $P$. pastoris.

Figura 22 - Representação do vetor pHXYLA e sítios de restrição para linearização para liberação dos cassetes de expressão introduzidos na levedura $P$. pastoris.. . .88 Figura 23 - Representação dos vetores, pPXYLA e pPXYLB, e sítios de restrição para linearização para liberação dos cassetes de expressão introduzidos na levedura P. pastoris...... 88 Figura 24 - Esquema para demonstração dos transformantes Mut+ e MutS para serem analisados em placa do tipo Deep Well.

Figura 25 - Análise eletroforética em gel de agarose $0,8 \%$, corado com brometo de etídio, dos produtos da amplificação obtidos por PCR de colônia de leveduras dos transformantes pPXYLA/SM+/40 e pPXYLB/SM+/15.

Figura 26 - Cinética da produção de HXYLA e HXYLB por P. pastoris por 144 h de indução na presença de $1 \%$ de metanol.

Figura 27 - Análise do perfil de proteínas secretadas pelos transformantes pPXYLA e pPXYLB em SDS-PAGE 13\% corado por Azul de Comassie.

Figura 28 - Perfil de proteínas secretadas pelo transformante pPXYLA/SM+/40 e pPXYLB/SM+/15. .94

Figura 29 - Atividade enzimática de $\beta$-xilosidase obtida pelos transformantes produtores de HXYLA.

Figura 30 - Cinética de produção de HXYLA por $96 \mathrm{~h}$ de cultivo pelos transformantes T1, T28, T38, T53 e T92, além do controle negativo (CN-pHIL-D2/SM+).

Figura 31 - Análise do perfil de proteínas secretadas pelo transformante T92 em gel de poliacrilamida $13 \%$ corado por Azul de comassie.

Figura 32 - Gráfico de Pareto mostrando o efeito da composição do meio de cultura sobre a produção da HXYLA por $P$. pastoris.

Figura 33 - Gráfico de superfície de resposta para a atividade de enzima HXYLA, em termos dos efeitos: (A) Concentração de metanol e Fonte de nitrogênio, (B) Fonte de nitrogênio e OD inicial, (C) Concentração de metanol e OD inicial.

Figura 34 - Efeito do pH inicial do meio de cultura na produção de HXYLA por P. pastoris. 103 Figura 35 - Cinética da produção de HXYLA por P. pastoris por $192 \mathrm{~h}$ de cultivo na presença de $2 \%$ de metanol e $\mathrm{pH}$ inicial de 7,0 .

Figura 36 - Cinética da produção de HXYLA por P. pastoris 192 horas na presença de 2\% de metanol e pH inicial de 7,0. 
Figura 37 - SDS-PAGE corado por azul de comassie (13\%) e zimograma da proteína recombinante HXYLA purificada. 106

Figura 38 - Efeito da temperatura e do $\mathrm{pH}$ sobre as propriedades enzimáticas da HXYLA recombinante.

Figura 39 -Gráfico do duplo recíproco correlacionando o inverso da concentração do substrato com o inverso da velocidade da reação para a enzima HXYLA.

Figura 40 - Efeito da concentração de xilose sobre a atividade da HXYLA recombinante.. ...114 Figura 41 - Gráfico do duplo recíproco para determinar os valores de Km e Vmax da HXYLA na presença de $500 \mathrm{mM}$ de inibidor.

Figura 42 - Cromatografia de camada delgada feita com o hidrolisado obtido a partir de reações com HXYN2 e HXYLA.

Figura 43 - Gráfico de Pareto para o efeito combinação das enzimas HXYN2, ABF3 e HXYLA para hidrólise do BCA.

Figura 44 - Gráfico de superfície tendo como fator resposta para liberação de açúcares redutores $(\mathrm{mg} / \mathrm{mL})$ em relação às variáveis independentes: (A) ABF3 e HXYLA; (B) ABF3 e HXYN2; (C) HXYN2 e HXYLA.

Figura 45 - Efeito da suplementação de Accelerase ${ }^{\circledR}$ (ACR) com as hemicelulases recombinantes (HXYN2 - $600 \mathrm{U} / \mathrm{mL}$; ABF3 - 0,32 U/mL; HXYLA - 11,5 U/mL) durante a hidrólise de BCA pré-tratado por explosão a vapor. 128 Figura 46 - Efeito da adição prévia com o coquetel de hemicelulases recombinantes (HXYN2 600U/mL; ABF3 - 0,32 U/mL; HXYLA - 11,5 U/mL) antes da adição da Accelerase ${ }^{\circledR}$ (ACR) durante a hidrólise de BCA pré-tratado por explosão a vapor. 130 


\section{LISTA DE TABELAS}

Tabela 1 - Composição aproximada de celulose, hemicelulose e lignina de alguns resíduos agroindustriais

Tabela 2 - Exemplos de hemicelulases fúngicas produzidas por P. pastoris (linhagens e promotor)

Tabela 3 - Linhagens de P. pastoris utilizadas e seus respectivos genótipos ................................30

Tabela 4 - Linhagens de E. coli utilizadas e seus respectivos genótipos .......................................30

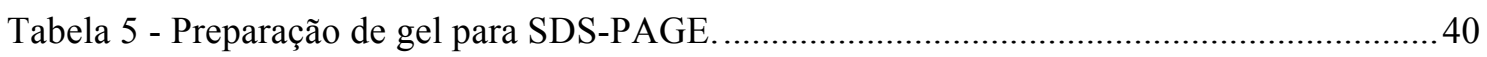

Tabela 6 - Lista de oligonucleotídeos utilizados para ABF de H. grisea.......................................46

Tabela 7 - Lista de oligonucleotídeos utilizados para primeira tentativa de amplificação de genes de $\beta$-xilosidase de $\mathrm{H}$. grisea

Tabela 8 - Demais oligonucleotídeos utilizados. Em negrito os sítios de restrição e sublinhado a sequência Histag.

Tabela 9 - Variáveis independentes, níveis e valores reais utilizados para composição do DCCR.

Tabela 10 -DCCR da otimização do meio de indução da produção de HXYLA por P. pastoris.

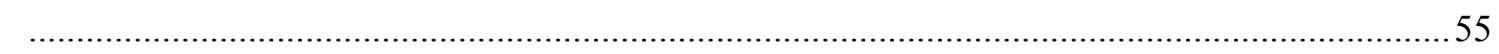

Tabela 11 - Preparo para obtenção de $20 \mathrm{~mL}$ de tampão Mcllvaine. 58

Tabela 12 - Variáveis independentes, níveis e valores reais utilizados para a composição do DCCR para análise da interação entre as três enzimas na hidrólise do BCA

Tabela 13 - DCCR para análise da interação entre as enzimas HXYN2, HXYLA e ABF3 na hidrólise do BCA pré-tratado por explosão a vapor.

Tabela 14 - Reações sequenciais e simultâneas com as enzimas HXYN2, HXYLA e ABF3....63 Tabela 15 - Valores de atividade enzimática para XYLs e ABFs obtidos pelo cultivo de $\mathrm{H}$. grisea na presença dos substratos, BCA e FT, como fonte de carbono. Os valores são referentes ao pico de produção das enzimas em cada substrato.

Tabela 16 - Sequências de $\beta$-xilosidases similares à HXYLA e HXYLB de H. grisea. Dados de identidade, similaridade e E-value obtidos por alinhamento local pelo programa BlastP. . .77 Tabela 17 -Efeito da composição do meio de cultura para a produção de HXYLA por P. pastoris.

Tabela 18 - Análise de variância (ANOVA) para atividade enzimática da HXYLA (U/mL)...100

Tabela 19 - Resumo do processo de purificação da HXYLA produzida por P. pastoris............106

Tabela 20 - Propriedades das enzimas fúngicas da família GH43

Tabela 21 - Efeito dos íons metálicos e reagentes químicos (5mM) na atividade da HXYLA. 111

Tabela 22 - Capacidade da enzima HXYLA purificada hidrolisar diferentes substratos. 
Tabela 23 - Resultado da hidrólise de xilana por HXYN2 e HXYLA em reações simultâneas e sequenciais

Tabela 24 - Hidrólise de xilanas comerciais por HXYN2 e ABF3 em reações simultâneas e sequenciais.

Tabela 25 - Efeito da composição da mistura enzimática composta por HXYN2, ABF3 e HXYLA para a hidrólise do BCA pré-tratado por explosão a vapor.

Tabela 26 - Análise de variância (ANOVA) para composição da mistura enzimática composta por HXYN2, ABF3 e HXYLA para a hidrólise do BCA pré-tratado por explosão a vapor. ....124 Tabela 27 - Efeito da suplementação sequencial e simultânea das enzimas HXYN2, ABF3 e HXYLA na hidrólise do BCA pré-tratado por explosão a vapor. 126

Tabela 28 - Características bioquímicas das enzimas recombinantes HXYN2, ABF3 e HXYLA.

Tabela 29 - Resultado da hidrólise do bagaço de cana-de-açúcar com as hemicelulases recombinantes e Accelerase ${ }^{\circledR}(\mathrm{ACR})$ em reações simultâneas e sequenciais. 


\section{LISTA DE ABREVIATURAS E SÍMBOLOS}

${ }^{\circ} \mathrm{C}$

AOX 1 e 2

$\mathrm{Kb}$

cDNA

dNTP

DO

EDTA

BCA

$g$

$\mathrm{h}$

HIS 4

FT

$\mathrm{Kb}$

$\mathrm{L}$

M

$\mathrm{mg}$

$\mathrm{Mb}$

$\min$

$\mathrm{mM}$

MM

$\%$

ng

ORF

$\mathrm{p} / \mathrm{v}$

$\mathrm{v} / \mathrm{v}$

$\mathrm{pb}$

YNB

PCR

$\mathrm{pH}$

SDS
Graus Celsius

Genes da álcool oxidase 1 e 2

Kilobase

Ácido Desoxirribonucléico Complementar

Deoxirribonucleotídeo

Densidade óptica

Ácido etilenodiaminotetracético

Bagaço de cana-de-açúcar

Velocidade de sedimentação em unidade gravitacional

Hora

Gene histidinol desidrogenase

Farelo de trigo

Kilobases

Litro

Molar

Miligrama

Mega base

Minutos

Milimolar

Massa molecular

porcentagem

Nanograma

Open Read Frame

Peso por volume

volume por volume

Pares de base

Yeast Nitrogen Base

Reação de polimerização em cadeia

Potencial hidrogeniônico

Dodecil Sulfato de Sódio 
q.s.p.

$\mathrm{ABF}$

XYL

XYN

rpm

TEMED

$\mathrm{Tm}$

Tris

$\mathrm{U}$

$\mu \mathrm{g}$
Quantidade suficiente para

Arabinofuranosidase

$\beta$-xilosidase

Endo-xilanase

Rotações por minuto

$\mathrm{N}, \mathrm{N}, \mathrm{N}^{\prime}, \mathrm{N}^{\prime}$-tetrametil etilenodiamina

Temperatura de desnaturação

Tris (hidroximetil) aminometano

Unidade de atividade enzimática

Micrograma 


\section{RESUMO}

A lignocelulose é o principal componente da biomassa vegetal, sendo constituída por celulose, hemicelulose e lignina. A xilana é o principal componente da hemicelulose e para a sua completa degradação é necessário a ação cooperativa de um sistema composto por várias enzimas, incluindo endo-xilanases (XYN), $\beta$-xilosidases (XYL) e $\alpha$-L-arabinofuranosidases (ABF). No presente trabalho, foi realizada a produção de hemicelulases recombinantes e a aplicação na hidrólise do bagaço de cana-de-açúcar (BCA) pré-tratado por explosão a vapor. As primeiras enzimas produzidas foram duas XYLs do fungo Humicola grisea var. Thermoidea, sendo esse o primeiro trabalho a reportar a caracterização de genes de XYLs de $H$. grisea, bem como, a sua expressão heteróloga e caracterização bioquímica. Os dois genes, hxylA e $h x y l B$, foram identificados a partir do genoma de H. grisea, um com 984 pb e outro com 1617 pb, respectivamente. Nenhum íntron e peptídio sinal foi encontrado e o domínio catalítico de GH43 estava presente em ambas. Os cDNAs correspondente as duas enzimas foram utilizados para a transformar duas linhagens de Pichia pastoris, GS115 e SMD1168. Uma otimização da produção da enzima denominada HXYLA foi realizada por meio de planejamento experimental $2^{3}$. A influência da densidade celular inicial, concentração de metanol e fonte de nitrogênio foi avaliada e o parâmetro mais significativo para a produção foi a concentração de metanol. A enzima HXYLA purificada foi utilizada para a realização da caracterização enzimática quanto ao $\mathrm{pH}$ e temperatura ótimos (7,0 e 50 ${ }^{\circ} \mathrm{C}$ ), efeito de íons e reagentes químicos na atividade de HXYLA, substrato específico e parâmetros cinéticos. A enzima HXYLA apresentou atividade de $\beta$-xilosidase e $\alpha$-Larabinofuranosidase, sendo uma enzima bifuncional e altamente tolerante a xilose, com elevado valor de $\mathrm{K}_{\mathrm{i}}(350 \mathrm{mM})$. Além das $\beta$-xilosidases, foi produzida e purificada uma endo-xilanase (HXYN2) recombinante de $H$. grisea a partir de um clone de P.pastoris obtido pelo grupo de pesquisa do laboratório de Biotecnologia de Fungos (UFG). Além dessas hemicelulases, uma $\alpha$-L-arabinofuranosidase (ABF3) de Penicillium purpurogenum teve seu cDNA introduzido em $P$. pastoris e a enzima foi produzida com sucesso. Após a produção hetoróloga das enzimas, foi utilizado um planejamento experimental $2^{3}$ para avaliar a melhor formulação contendo as três hemicelulases recombinantes (HXYN2, ABF3 e HXYLA) para a hidrólise do BCA pré-tratado por explosão a vapor, sendo possível estabelecer uma mistura capaz de realizar a conversão da fração residual de xilana em xilose, sendo a bioconversão eficiente da fração de xilana do BCA uma etapa imprescindível para o aproveitamento da xilose. A melhor formulação contendo as três hemicelulases recombinantes foi obtido com a menor concentração de $\mathrm{ABF} 3$, sendo que essa enzima foi a que exerceu efeito mais significativo durante a hidrólise do BCA. Além disso, o coquetel contendo as hemicelulases recombinantes foi utilizado para suplementar uma mistura de celulases comerciais aumentando significativamente a liberação de glicose a partir do BCA, o que mostrou a capacidade das hemicelulases de melhorar a digestibilidade de celulose e tornar o processo de hidrólise mais eficiente. Nossos resultados mostram o potencial de atividades acessórias para aumentar a hidrólise enzimática, tais como XYNs, ABFs e XYLs, que estão ausentes ou presentes em pequenas proporções nas celulases comerciais. 


\begin{abstract}
Lignocellulose is the main component of plant biomass, which consists of cellulose, hemicellulose and lignin. Xylan is the main component of hemicellulose and for its complete degradation is required cooperative action of a system consisting of several enzymes including endo-xylanases (XYN), $\beta$-xylosidases (XYL) and $\alpha$-Larabinofuranosidases $(\mathrm{ABF})$. In the present work, the production of recombinant hemicellulases and its application in the hydrolysis of sugarcane bagasse (SCB) pretreated by steam explosion was performed. The first enzymes produced were two XYLs from Humicola grisea var thermoidea and this was the first study to report the genes characterization of XYLs from $H$. grisea, as well its heterologous expression and biochemical characterization. The two genes, $h x y l A$ and $h x y l B$, were identified from the H. grisea genome, with $984 \mathrm{bp}$ and $1617 \mathrm{bp}$, respectively. No intron and signal peptide were found and the GH43 catalytic domain was present in both. The cDNAs of both enzymes were used to transform two strains of Pichia pastoris, GS115 and SMD1168. A production optimization of enzyme denominated HXYLA was performed by a $2^{3}$ factorial design. The influence of the initial cell density, methanol concentration and nitrogen source was assessed and the most significant parameter for the HXYLA production was methanol concentration. The purified enzyme was used to carry out the enzymatic characterization as optimal $\mathrm{pH}$ and temperature $\left(7.0\right.$ and $\left.50{ }^{\circ} \mathrm{C}\right)$, effect of ions and chemical reagents in HXYLA activity, substrate specific and kinetic parameters. HXYLA is a bifunctional enzyme, displaying $\beta$-xylosidases and $\alpha$-Larabinofuranosidases activity, also that enzyme was highly tolerant xylose with high $\mathrm{K} i$ value $(350 \mathrm{mM})$. In addition to $\beta$-xylosidases, a recombinant endo-xylanase (HXYN2) from $H$. grisea was produced and purifield from a $P$. pastoris clone obtained by the research group from Fungal Biotechnology Laboratory (LBF/UFG). It was also produced one $\alpha$-L-arabinofuranosidases (ABF3) from Penicillium purpurogenum which had its cDNA introduced in $P$. pastoris and the enzyme has been successfully produced. After the production of these enzymes, a $2^{3}$ factorial design was used to evaluate the best formulation containing the three recombinant hemicellulases (HXYN2, ABF3 and HXYLA) for the SCB pretreated by steam explosion hydrolysis. It was possible to formulate a mixture capable to performing the conversion of the xylan fraction in the xylose, being efficient bioconversion of SCB xylan fraction an essential step for the utilization of xylose. The best formulation containing these three recombinant hemicellulases was obtained with the lowest concentration of ABF3, and it had most significant effect exerted during SCB hydrolysis. Also, the cocktail containing recombinant hemicellulases was used to supplement a mixture of commercial cellulase and it showed significantly increasing the release of glucose from the SCB hydrolysis, which showed the ability of hemicellulases to improve the digestibility of cellulose and make the hydrolysis process more efficient. Our results showed the potential for auxiliary activities to increase the enzymatic hydrolysis, such as XYNs, ABFs and XYLs who are absent or present in small amounts in comercial cellulases.
\end{abstract}


Tntroduçãa 


\section{INTRODUÇÃO}

A conversão da biomassa vegetal em açúcares fermentescíveis por hidrólise enzimática representa uma alternativa para a utilização de resíduos agroindustriais, tais como, bagaço de cana-de-açúcar (BCA), farelo de trigo (FT), sabugo de milho (SM), palha de arroz (PA), dentre outros. A biomassa vegetal é composta, principalmente, por materiais lignocelulósicos formados por celulose, hemicelulose e lignina.

A celulose e hemicelulose são polissacarídeos que podem ser convertidos por uma etapa denominada de sacarificação, onde essas frações são hidrolisadas por enzimas à açúcares monoméricos. Para facilitar o acesso das enzimas, esses polissacarídeos podem ser submetidos à uma etapa de pré-tratamento que pode remover a lignina e a hemicelulose ou apenas aumentar a porosidade das fibras de celulose e a

A remoção da fração de hemicelulose dos materais lignocelulósicos durante a etapa de pré-tratamento aliada a sua baixa capacidade de fermentação de seus monômeros pelas linhagens de leveduras industriais mais comuns, faz com que a hemicelulose seja, normalmente, desperdiçada durante os processos de reaproveitamento da biomassa vegetal. A conversão da fração de hemicelulose é essencial para aumentar o rendimento da produção de açúcares fermentáveis a partir desses resíduos lignocelulósicos.

As hemicelulases são enzimas que são requeridas no processo de hidrólise dos polissacarídeos a monômeros de açúcares. Um dos desafios para a produção de açúcares a partir da biomassa vegetal, seja para produção de bioetanol ou para outros fins, consiste na produção de enzimas lignocelulolíticas em larga escala e de baixo custo. Algumas estratégias têm sido propostas para alcançar este objetivo como, por exemplo, a prospecção de micro-organismos produtores de celulases e hemicelulases, obtenção de micro-organismos superprodutores de enzimas por meio de melhoramento dos processos fermentativos ou programas de melhoramento genético e ainda a obtenção de enzimas recombinantes que possam complementar o complexo enzimático produzido por micro-organismos com atividades específicas.

A ação sinérgica entre as hemicelulases e celulases forma a base da degradação da lignocelulose na natureza e pode ser empregada para o desenvolvimento de sistemas enzimáticos lignocelulolíticos eficientes para aplicação biotecnológica. A partir do reaproveitamento da fração de hemicelulose, podem ser obtidos vários produtos de valor agregado, como a xilose e o xilitol (edulcorantes); os xilooligosacarídeos de 
cadeia curta ( 2 a 7) que são utilizados na indústria farmacêutica e alimentícia e para produção de bioetanol por micro-organismos que fermentam C5. Com base no exposto, este trabalho propõe utilizar algumas hemicelulases-chave (endo-xilanases, arabinofuranosidases e $\beta$-xilosidases) para utilização na hidrólise da fração de hemicelulose do bagaço de cana-de-açúcar.

\section{REVISÃO DE LITERATURA}

$\mathrm{Na}$ revisão de literatura serão apresentados os principais constituintes da biomassa vegetal, com o foco na hemicelulose. Serão descritos o modo de ação, importância e aplicação de algumas hemicelulases-chave no processo de hidrólise enzimática (endo-xilanases, $\beta$-xilosidases e arabinofuranosidases). Além disso, será descrito a importância da utilização da levedura Pichia pastoris para produção de enzimas lignocelulolíticas e como exemplo de fungos produtores de hemicelulases, serão apresentados os fungos Humicola grisea var thermoidea e Penicillium pupurogenum e, por fim, uma breve revisão sobre o sinergismo das enzimas xilanolíticas na hidrólise da biomassa vegetal.

\section{1 - Biomassa vegetal: lignocelulose}

A biomassa vegetal representa a fonte renovável mais abundante encontrada na natureza, abrangendo os materiais agroindustriais, os resíduos urbanos e as madeiras de angiospermas e gimnospermas. A lignocelulose é constituída de carboidratos como, celulose e hemicelulose, lignina, pectina, proteínas e minerais. A celulose e hemicelulose são macromoléculas constituídas por diferentes açúcares; e a lignina é uma macromolécula aromática sintetizada a partir de precursores fenilpropanóides. Estes polímeros encontram-se conectados por ligações covalentes e não covalentes, formando uma malha entrelaçada na parede das células vegetais (SÁNCHEZ, 2009) (Figura 1). 


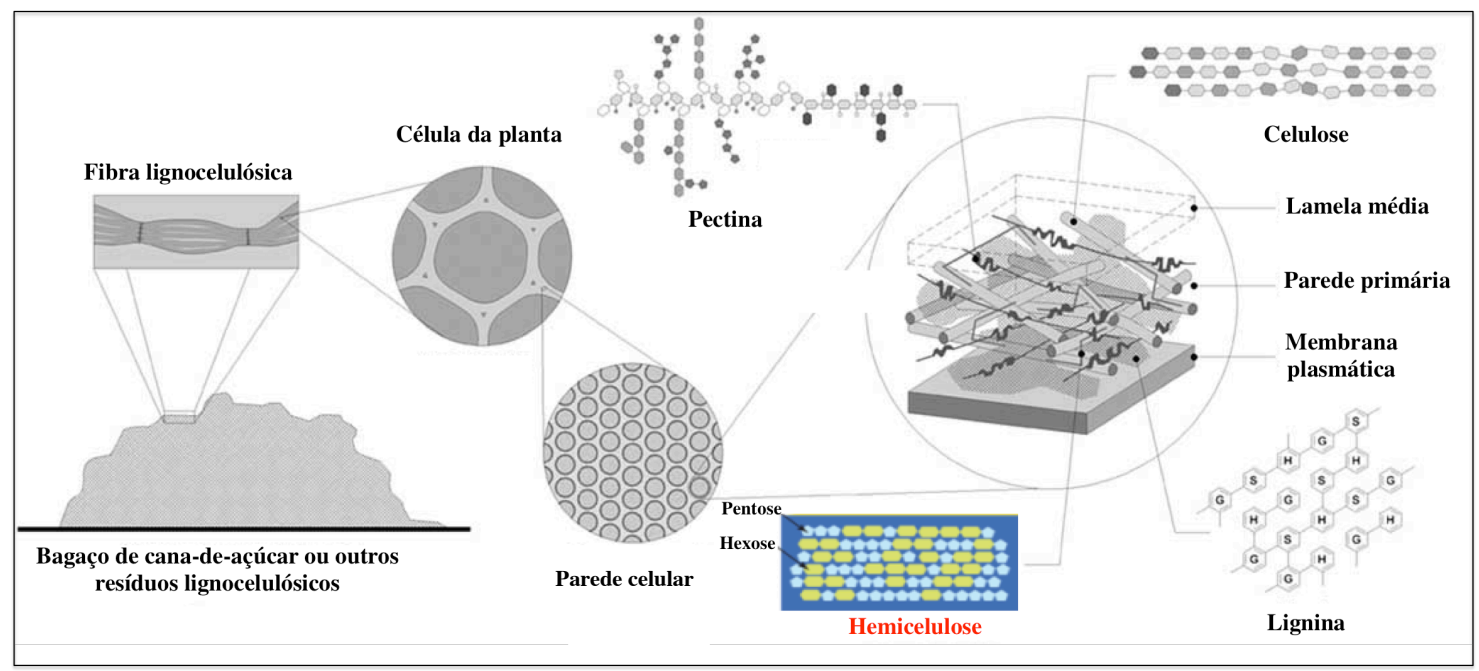

Figura 1 - Estrutura da parede celular do bagaço de cana-de-açúcar ou outros resíduos agroindustriais (adaptado de SIQUEIRA, F. G.; FILHO, E. X. F., 2010).

A composição de vários materiais lignocelulósicos tem sido reportada na literatura e pode variar dependendo da espécie, do tecido vegetal, da fase de crescimento, idade, dentre outros. O bagaço de cana de açúcar (BCA) e o Farelo de Trigo (FT), bem como os demais resíduos lignocelulósicos, apresentam teor de celulose, hemicelulose e lignina que pode se diferenciar dependendo das variedades, como mostrado na Tabela 1 .

Tabela 1 - Composição aproximada de celulose, hemicelulose e lignina de alguns resíduos agroindustriais.

\begin{tabular}{ccccc}
\hline Biomassa & Celulose & Hemicelulose & Lignina & Referência \\
\hline $\begin{array}{c}\text { Bagaço de cana } \\
\text { de açúcar (BCA) }\end{array}$ & $35-42,2 \%$ & $25-27,6 \%$ & $22 \%$ & $\begin{array}{c}\text { (REZENDE et al., 2011; } \\
\text { ROCHA et al., 2015) }\end{array}$ \\
$\begin{array}{c}\text { Palha de trigo } \\
\text { (PT) }\end{array}$ & $35-46 \%$ & $23-27 \%$ & $19-21 \%$ & $\begin{array}{c}\text { (CHEN et al., 2015; } \\
\text { ZHONG et al., 2015) }\end{array}$ \\
$\begin{array}{c}\text { Palha de arroz } \\
\text { (PA) }\end{array}$ & $32-41 \%$ & $21-24 \%$ & $09-18 \%$ & $\begin{array}{c}\text { (VAN DYK; } \\
\text { (PLETHKE, 2012) }\end{array}$ \\
$\begin{array}{c}\text { Sabugo de milho } \\
\text { (SM) }\end{array}$ & $45 \%$ & $35 \%$ & $15 \%$ & (HOWARD et al., 2004) \\
$\begin{array}{c}\text { Farelo de trigo } \\
\text { (FT) }\end{array}$ & $11 \%$ & $39 \%$ & $5 \%$ & (CRIPWELL et al., 2015) \\
\hline
\end{tabular}


$\mathrm{Na}$ natureza, a biodegradação da biomassa vegetal acontece como um processo lento, principalmente, em função da presença da lignina que restringe o acesso das enzimas hidrolíticas aos componentes dos polissacarídeos (BERLIN et al., 2007).

A lignina é uma macromolécula complexa que apresenta uma estrutura tridimensional altamente irregular em sua constituição sendo composta por unidades de fenil propano, composta por 9 unidades de carbono, derivadas do álcool cinamil substituído, que são cumaril, coniferil e álcool siringil. As ligninas são altamente ramificadas, não cristalinas, com estrutura e composição química variando de acordo com a fonte de origem. A lignina do tipo G-S-H (Guaiacila-Siringila- $\rho$-Hidroxifenila) normalmente é encontrada em gramíneas (FELDMAN, 1985). Há estudos mostrando que o ácido fórmico e as unidades precursoras de lignina inibem enzimas como celulases (PANAGIOTOU; OLSSON, 2007). Além disso, a hidrofobicidade da lignina pode promover a adsorção das celulases e hemicelulases (JØRGENSEN; OLSSON, 2006).

Várias pesquisas tem focado na investigação das vias de regulação dos genes que produzem componentes da lignina e formas para reorganizar a composição da lignina, alterando a proporção relativa das suas subunidades visando a hidrólise mais eficiente da biomassa vegetal (SIMMONS; LOQUÉ; RALPH, 2010). Tem sido reportado a influência da proporção siringila $(\mathrm{S}) / \mathrm{Guaiacila}(\mathrm{G})$ nas propriedades físicas e químicas da parede celular (CHEN; DIXON, 2007; PAPA et al., 2012; STUDER et al., 2011; RUBINELLI et al., 2013), além de estudos que mostram que modificação das ligações químicas dentro e entre estes componentes da lignina podem facilitar a desconstrução da biomassa vegetal, o que leva à maior liberação de açúcares monoméricos durante o processo de hidrólise (FURTADO et al., 2014).

A pectina é um dos principais componentes da parede celular das plantas e o principal componente da lamela média. É um heteropolissacarídeo complexo composto por ligações axiais de unidades de ácido $\alpha$-1,4-D-galacturônico composto por ramose, arabinose e galactose. As principais enzimas envolvidas na hidrólise da pectina são pectina liases (EC 4.2.2.10), pectato liases (EC 4.2.2.2) e poligalacturonase (EC 3.2.1.15 e EC 3.2.1.67) (DE VRIES; VISSER, 2001).

A celulose é um homopolímero linear formada por monômeros de glicose unidos por ligações glicosídicas do tipo $\beta-1,4$. As cadeias de celulose se conectam por ligações de hidrogênio formando fibras de celulose com regiões altamente ordenadas 
(região cristalina) e regiões onde as fibras estão menos organizadas (região amorfa). Cada resíduo de glicose tem uma orientação de $180^{\circ}$ em relação ao resíduo adjacente, formando uma unidade repetitiva de dois resíduos que se denomina celobiose. A extremidade da cadeia de celulose em que se encontra um carbono anomérico livre é chamada de extremidade redutora, e a extremidade em que o carbono anomérico não está disponível é chamada de não redutora (LYND et al., 2002).

As celulases constituem um complexo de enzimas envolvidas na conversão da celulose a glicose. As enzimas do sistema celulolítico foram classificadas com base no modo de catálise sobre a fibra de celulose e em fungos há três classes principais de enzimas hidrolíticas: endo-glucanases, exo-glucanases e $\beta$-glicosidases (JUTURU; WU, 2014).

As endo-glucanases (EGLs - EC 3.2.1.4) clivam ligações internas nas microfibrilas que se encontram nas regiões amorfas da fibra de celulose, diminuindo o comprimento das mesmas e, consequentemente, gerando novas extremidades livres; as exoglucanases ou celobiohidrolases (CBHs - EC 3.2.1.91) agem de maneira progressiva nas extremidades redutoras (CBHI) ou não-redutoras (CBHII) da celulose, com maior afinidade por celulose insolúvel ou microcristalina, liberando glicose e principalmente moléculas de celobiose como produtos; as $\beta$-glicosidases (BGLs - EC 3.2.1.21) atuam nos celooligossacarídeos e celobiose liberados e os hidrolisam a glicose (LYND et al., 2002; SHARMA et al., 2016a). As BGLs são muito importantes para a degradação de celulose, pois elas impedem a ação inibitória da celobiose sobre as celulases (SREEDHARAN et al., 2016)

As endo-glucanases, exo-glucanases e $\beta$-glicosidases atuam de forma sinergística sobre o substrato (HU et al., 2015). Além disso, as celulases são amplamente utilizadas em interação com as hemicelulases a fim de melhorar o rendimento na hidrólise da celulose (HU et al., 2013).

\section{2 - Hemicelulose}

Ao contrário da celulose, a hemicelulose não é quimicamente homogênea. Por serem polímeros heterogêneos, as hemiceluloses podem conter pentoses ( $\beta$-D-xilose, $\alpha$ L-arabinose), hexoses ( $\beta$-D-manose, $\beta$-D-glicose, $\alpha$-D-galactose), ácidos urônicos $(\alpha$ D-glucorônico, $\alpha$-D-4-O-metilgalacturonico e $\alpha$-D-ácidos galacturônico) sendo geralmente formadas por 2 a 6 açúcares diferentes unidos por ligações do tipo $\beta-1,4$ e, às vezes, por ligações do tipo $\beta$-1,3-glicosídicas (SÁNCHEZ, 2009). 
As hemiceluloses são classificadas, de acordo com a identidade dos principais açúcares presentes, como glucanas, xilanas, mananas, galactanas e galacturanas. Outros açúcares, como a $\alpha$-L-ramnose e $\alpha$-L-fucose podem também estar presentes em pequenas quantidades e os grupos hidroxilas dos açúcares podem ser parcialmente substituídos por grupos acetil (GÍRIO et al., 2010).

A xilana constitui o principal componente da hemicelulose e é o segundo polissacarídeo constituinte da biomassa vegetal mais abundante na natureza após a celulose. A celulose, a hemicelulose e a lignina interagem através de ligações covalentes e não covalentes, sendo a xilana o polissacarídeo encontrado na interface entre a lignina e a celulose. Acredita-se que sua importância está na coesão da fibra e na integridade da parede celular das plantas (COLLINS; GERDAY; FELLER, 2005).

A xilana é um heteropolissacarídeo formado por uma cadeia principal de resíduos de D-xilopiranose unidos por ligações do tipo $\beta-1,4$ podendo conter cadeias laterais nas posições 2 e 3 de resíduos $\alpha$-L-arabinofuranose, ácido D-glucurônico ou grupamento acetil (ASPINALL, G. O., 1959). Além disso, os resíduos de Larabinofuranosil nas cadeias laterais podem ser esterificados com ácido ferúlico e ácido pcumárico (COUGHLAN; HAZLEWOOD, 1993) (Fig.2).

Considerando o tipo de ramificação presente na cadeia central, as xilanas podem ser denominadas de arabinoxilanas, glucuronoxilanas, arabinoglucuronoxilanas e glucuronoarabinoxilana (DEKKER, R. F. H., 1989). A xilana é ligada quimicamente à lignina pela ligação do tipo ester entre o C-5 do resíduo de $\alpha$-L-arabinofuranose e o ácido ferúlico (KROON et al., 1999). A arabinoxilana é um dos principais componentes de matérias-primas que são atualmente estudadas como uma fonte para os biocombustíveis (LAGAERT et al., 2014). O grau de substituição e a natureza dos substituintes da cadeia lateral dependem da fonte e da espécie a partir da qual a xilana foi isolada (GÍRIO et al., 2010).

Algumas xilanas são comercializadas purificadas como, por exemplo, a xilana de madeira de faia (beechwood) (Sigma®) que apresenta 83,7\% de xilose, 9,4\% de ácido glucurônico e 6,9\% de outros açúcares em sua composição. A arabinoxilana de trigo (wheat arabinoxylan) distribuída pela Megazyme, apresenta em sua constituição $36 \%$ de arabinose, $51 \%$ de xilose, $6,5 \%$ de glicose, $4,4 \%$ de manose e $1,6 \%$ de galactose. A xilana de aveia (oat spelt) apresenta $81,4 \%$ de xilose, 9,7\% de arabinose, 1,1\% de galactose e 3,4\% de ácido glucurônico (Sigma®) (KORMELINK; VORAGEN, 1993). 
A conversão da xilana em unidades de xilose requer a ação sinérgica de um complexo de enzimas denominado sistema xilanolítico (Fig. 2). As endoxilanases (EC 3.2.1.8) hidrolisam as ligações glicosídicas do tipo $\beta-1,4$ dentro da cadeia da xilana produzindo xilo-oligossacarídeos, os quais são convertidos em xilose pela $\beta$-xilosidase (EC 3.2.1.37) (KIRIKYALI; CONNERTON, 2015).

A conversão da xilana requer ainda a ação de enzimas acessórias como: arabinofuranosidases (EC 3.2.1.55) que clivam a ligação entre o resíduo lateral de arabinofuranose e a xilose da cadeia central; glucuronidases (EC 3.2.1.139) que clivam as ligações glicosídicas do tipo $\alpha-1,2$ entre o ácido glucurônico lateral e a xilose da cadeia central; acetil xilana esterase (EC 3.1.1.72), que clivam as ligações entre o ácido acético e os C-2 e C-3 dos resíduos de xilose; ácido cumárico esterase e ácido fenólico esterase que clivam as ligações do tipo éster entre ácido cumárico e ácido fenólico e os resíduos de arabinofuranose. Todas estas enzimas atuam sinergisticamente para converter a xilana em unidades de xilose (GÍRIO et al., 2010; POLIZELI et al., 2005;

SÁNCHEZ, 2009).

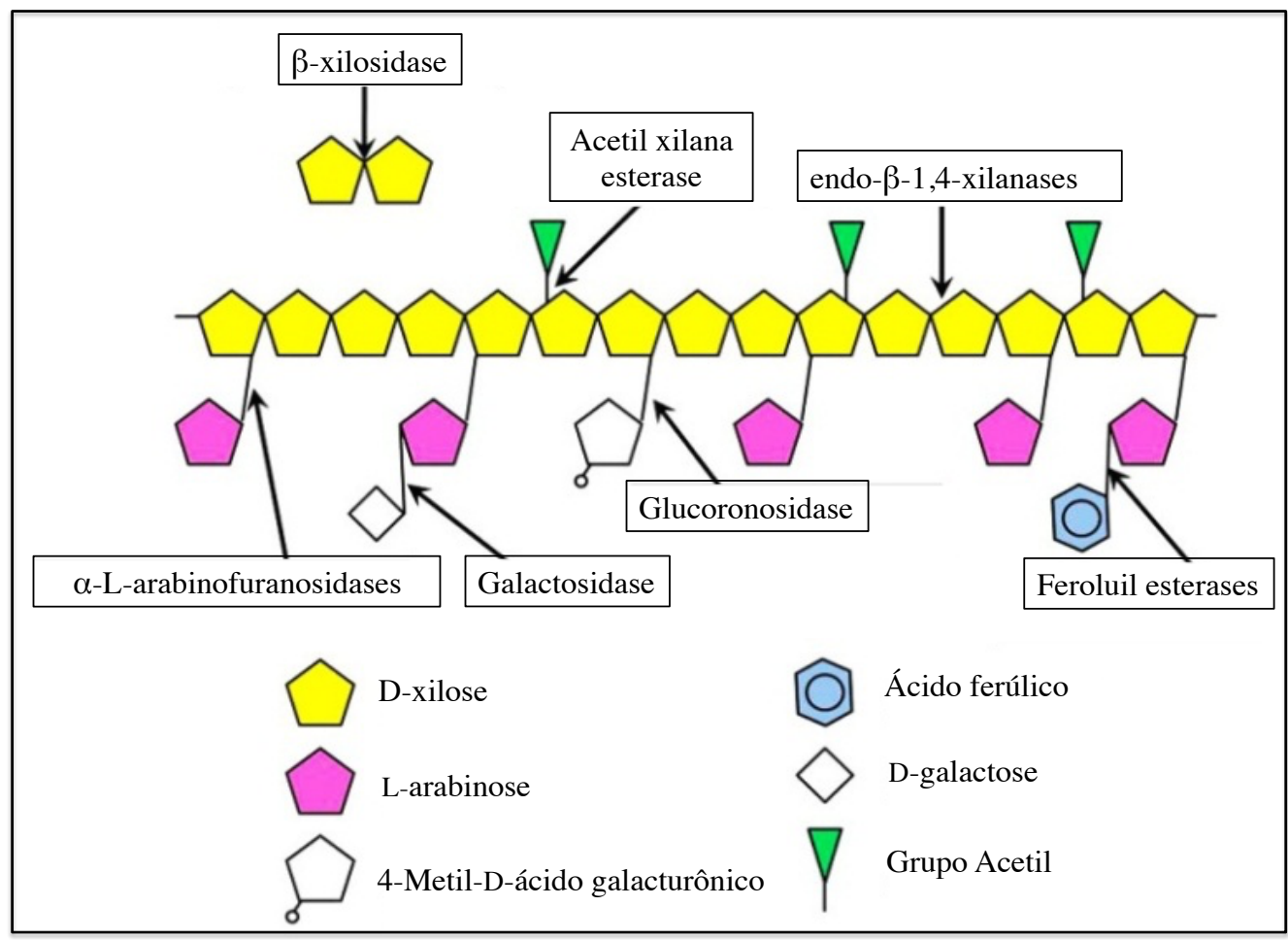

Figura 2 - Esquema da composição da xilana e enzimas envolvidas envolvidas na degradação da xilana (Adaptado de RATANAKHANOKCHAI et al., 2013). 
Várias enzimas xilanolíticas têm sido empregadas em diversas aplicações biotecnológicas como, por exemplo, na melhora da digestibilidade na alimentação animal, produção de adoçantes, produtos farmacêuticos, produção de biocombustíveis e fabricação de papel. As xilanases também são empregadas na etapa de hidrólise enzimática para a produção de bioetanol, onde são incluídas nas formulações de celulases para melhorar o rendimento da hidrólise da fração de celulose de resíduos lignocelulósicos por aumentar o acesso de celulases à fibra de celulose (GONÇALVES et al., 2015; HU et al., 2013; LAOTHANACHAREON et al., 2015).

Algumas enzimas agem sobre as ligações entre um resíduo da cadeia principal e um substituinte, ao passo que outras clivam ligações internas ou terminais da cadeias laterais. As enzimas acessórias, são enzimas que atuam sobre os substituintes das cadeias laterais (DE VRIES; VISSER, 2001). Dentre as enzimas que atuam na cadeia principal da xilana, pode-se citar as endo-xilanases e as $\beta$-xilosidases e um exemplo de enzima acessória, também conhecidas como desramificadoras, são as $\alpha$-Larabinofuranosidases. A seguir, são descritas as funções e mecanismos de ação dessas três enzimas.

\subsection{1 - Endoxilanases}

As endo- $\beta-1,4-x i l a n a s e s$ (XYN - EC 3.2.1.8) são as principais enzimas envolvidas na hidrólise da xilana e clivam as ligações glicosídicas do tipo $\beta$-1,4 entre os resíduos de xilose da cadeia central liberando xilooligossacarídeos (XOs) (COLLINS; GERDAY; FELLER, 2005). Os XOs, exibem várias atividades biológicas, como atividade antioxidante, antibacteriana e também podem atuar como anti-tumorigênico e prebióticos, sendo utilizados, principalmente, pela indústria cosmética e farmacêutica (AACHARY; PRAPULLA, 2011; REDDY; KRISHNAN, 2015).

As endoxilanases são enzimas complexas que podem ter diferentes propriedades físico-químicas, estruturais e atividades específicas. Essas enzimas formam o maior grupo de enzimas hidrolíticas envolvidas na degradação da xilana (KUMAR; SHUKLA, 2016).

As enzimas que degradam biomassa vegetal, que são enzimas ativas em carboidratos (CAZy - http://www.cazy.org/) são agrupadas em diferentes famílias com base nas sequências de aminoácidos. As glicosil hidrolases (EC 3.2.1.-) são um grupo de enzimas que são capazes de hidrolisar a ligação glicosídica entre dois ou mais carboidratos ou entre um carboidrato e uma porção não-carbohidrato (HENRISSAT; 
DAVIES, 1997). Esta classificação é útil para estudar relação evolutiva, dar informações sobre mecanismo de ação e características estruturais dessas enzimas.

As XYNs são classificadas nas famílias 5, 8, 10, 11 e 43 das glicosil hidrolases (CANTAREL et al., 2009), entretanto, estão em sua maioria nas famílias 10 (GH10) (41\%) e 11 (GH11) (55\%). As XYNs pertencentes a essas duas famílias diferem entre si de acordo com suas propriedades físico-químicas (massa molecular e ponto isoelétrico), bem como na sua ação sobre os polissacarídeos e XOs (ÁLVAREZCERVANTES et al., 2016).

As xilanases GH 10, geralmente, apresentam alta massa molecular e baixo ponto isoelétrico comparado com as XYNs da família GH 11 que apresentam uma massa molecular média de cerca de $40 \mathrm{kDa}$. Além disso, as XYNs GH 10 têm um domínio catalítico que exibe um enovelamento do tipo barril $(\beta / \alpha)_{8}$, ao passo que as XYNs GH 11, têm uma estrutura do tipo $\beta$-jelly roll (COLLINS; GERDAY; FELLER, 2005; KUMAR; SHUKLA, 2016).

Ambas as famílias utilizam o mesmo mecanismo catalítico de duplo deslocamento com retenção da configuração anomérica, que envolvem dois resíduos de glutamato altamente conservadas dentro do sítio ativo, um deles atuando como doador de prótons e o outro como um nucleófilo (JUTURU; WU, 2012).

A ação das endo-xilanases nos materiais lignocelulósicos é limitada pelo número de substituições de unidades xilopiranosil. Membros da GH 10 são capazes de clivar as ligações glicosídicas na cadeia principal da xilana, próximas dos substituintes, de ácido4-O-metil-glucurônico, $\alpha$-L-arabinofuranose e grupamento acetil. As endoxilanases da família GH 10 exibem maior afinidade por produtos de hidrólise mais curtos que os membros da família GH11 (BIELY et al., 1997).

XYNs recombinantes de Nonomuraea flexuosa (GH11 - Xyn11A) e de Thermoascus aurantiacus (GH10 - Xyn10A) foram purificadas e apresentaram termoestabilidade. A enzima Xyn10A exibiu maior eficiência hidrolítica que Xyn11A sobre diversos substratos lignocelulósicos, liberando mais açúcares redutores. Devido à elevada atividade catalítica e termoestabilidade, a Xyn10A demonstrou um grande potencial para hidrólise de materiais lignocelulósicos, enquanto que a Xyn11A apresentou maior potencial para a produção de XOs (ZHANG et al., 2011a).

Em contrapartida, um estudo comparando duas XYNs termoestáveis de Thermobacillus xylanilyticus na hidrólise do farelo de trigo indicaram que a 
endoxilanase da família GH11 foi mais eficiente que da família GH10 na conversão do farelo de trigo em oligossacarídeos solúveis (BEAUGRAND et al., 2004).

Os fungos são conhecidos por secretarem múltiplas xilanases das várias famílias importantes para completa degradação das formas altamente variadas da hetoxilana de diversas fontes vegetais (LIAO et al., 2015). O fungo Aspergillus ochraceus produz pelo menos três xilanases (MICHELIN et al., 2014), Trichoderma reesei produz seis xilanases (BIELY et al., 2014) e o fungo Penicillium oxalicum GZ-2 produz pelo menos 6 xilanases com várias propriedades bioquímicas e funções diferentes (LIAO et al., 2015).

As endoxilanases, bem como outras enzimas do sitema xilanolítico, apresentam potencial biotecnológico para atuarem em vários processos industriais como, por exemplo, o biobranqueamento da polpa de celulose para remoção da hemicelulose, a utilização da biomassa hemicelulósica para produção de biocombustíveis, alimentação humana e animal, panificação e produção de xilitol (KUMAR; SHUKLA, 2016).

\subsection{2 - $\beta$-xilosidases}

As $\beta$-xilosidases (XYL) são enzimas-chave no sistema xilanolítico e podem ser utilizadas em muitos processos biotecnológicos como, por exemplo, em sinergismo com celulases e outras hemicelulases para degradação da biomassa que será utilizada na produção de bioetanol ou na produção de XOs utilizados como prebióticos em indústrias de alimentos (REDDY; KRISHNAN, 2015). Além disso, podem ser utilizadas em combinação com endoxilanases em vários processos para melhorar o cozimento da massa de pão, melhorar a digestibilidade de alimentos para animais e na produção de xilose para a formação de xilitol (KNOB; TERRASAN; CARMONA, 2010).

As XYLs atacam as extremidades não redutoras dos XOs para liberar xilose, xilobiose ou outros oligossacarídeos. As funções das XYLs incluem não somente a degradação de XOs, mas também desempenham um papel importante na degradação da xilana, removendo o produto final (xilooligômeros e xilobiose) que inibe as XYNs e que pode limitar a hidrólise da xilana (POLIZELI et al., 2005).

As XYLs, podem ser secretadas ou, na maioria dos casos, se encontram aderidas às células e isso pode variar dependendo das condições de cultivo ou do microorganismo. A temperatura de crescimento e a fonte de carbono podem inteferir na secreção de XYL (LENARTOVICZ et al., 2003). No caso dos fungos filamentosos, as XYLs podem permanecer associadas ao micélio durante os estágios iniciais de 
crescimento e podem ser liberadas no meio mais tarde, quer por secreção ou como um resultado da lise celular. No caso de bactérias e leveduras, as XYLs estão associadas às células e, quando isso ocorre, é necessário que os XOs entrem na célula antes da hidrólise (PECIAROVÁ; BIELY, 1982).

Com base nas sequencias de aminoácidos, as $\beta$-xilosidases têm sido classificadas nas famílias 3, 28, 30, 39, 43, 52 e 54 das glicosil hidrolases (GH) (http://www.cazy.org/ Glycoside-Hydrolases.html) (HENRISSAT; DAVIES, 1997). Por serem membros da família das glicosil hidrolases, essas enzimas hidrolisam a ligação glicosídica por retenção (GH 3, 28, 30, 39, 52 e 54) ou a inversão (GH43) da configuração do carbono anomérico. Uma característica estrutural comum entre as enzimas GH43 é a presença de cinco lâminas de $\beta$-hélice (JORDAN et al., 2007).

Muitas XYLs de bactérias e fungos foram purificadas e características bioquímicas analisadas (BHATTACHARYYA et al., 1997; KNOB; TERRASAN; CARMONA, 2010; PAN; YAO; LI, 2001; TENG et al., 2011; YAN et al., 2008). Para os fungos filamentosos, a maioria das XYLs descritas estão agrupadas na família GH3 (HENRISSAT; DAVIES, 1997) enquanto apenas algumas XYLs descritas são pertencentes à família GH 43 (TENG et al., 2011; SUZUKI et al., 2010; RAVANAL et al., 2013; YANG et al., 2014). A maioria dos membros da família GH43 descritos até o momento são produzidas por bactérias (KOUSAR; MUSTAFA; JAMIL, 2013).

Várias XYLs fúngicas e bactérianas têm sido relatadas como enzimas bifuncionais, apresentando atividade de $\beta$-xilosidase e $\alpha$-L-arabinofuranosidase (HUY et al., 2013b; RAVANAL et al., 2013; SAKKA et al., 1993; UTT et al., 1991; VIBORG et al., 2013). As atividades bifuncionais de $\beta$-xilosidases ocorrem devido às semelhanças espaciais entre D-xilopiranose and L-arabinofuranose, em particular as suas ligações glicosídicas e grupos hidroxilas (HUY et al., 2013b).

As XYLs são capazes de mediar reações de transxilosilação, que é a capacidade de formar novas ligações glicosídicas, originando mais cadeias de oligossacarídeos (transglicosilação) (DROUET; ZHANG; LEGOY, 1994). Vários estudos relataram $\beta$ xilosidases fúngicas com capacidade de transxilosilação (BENASSI et al., 2013; DILOKPIMOL et al., 2011; NIETO-DOMÍNGUEZ et al., 2015; PAN; YAO; LI, 2001; XIA et al., 2015). As XYLs da família GH43 não apresentam transxilosilação, mesmo em concentrações elevadas de substrato (JORDAN et al., 2007).

Assim como as endo-xilanases podem ser inibidas por xilobiose e xilooligosacarídeos curtos, as XYLs podem ser inibidas pela xilose. Nesse sentido, há 
grande interesse pela busca de XYLs que sejam tolerantes a xilose (MUSTAFA et al., 2016).

Muitas XYLs podem catalisar a transferência de resíduos de xilopiranosil para diversos receptores como, por exemplo, monossacarídeos, dissacarídeos , álcoois (metanol, etanol, isopropanol, butanol e glicerol), componentes fenólicos e hidroquinonas (KNOB; TERRASAN; CARMONA, 2010).

As XYLs são, normalmente, isoladas e purificadas por diferentes técnicas cromatográficas tais como, troca-iônica e cromatografia de exclusão de peso molecular. De maneira geral, as $\beta$-xilosidase isoladas e purificadas a partir de fungos ganharam muita atenção em comparação com bactérias, visto que a maioria das $\beta$-xilosidases fúngicas caracterizadas são extracelulares (KNOB; TERRASAN; CARMONA, 2010).

As XYLs caracterizadas até o momento, apresentam uma ampla faixa de $\mathrm{pH}$ ótimo que pode variar entre 2,0 a 9,0 . A temperatura ótima varia de $30^{\circ} \mathrm{C}$ a $80^{\circ} \mathrm{C}$, mas a maioria das XYLs apresentam melhores resultados à $60^{\circ} \mathrm{C}$ (KOUSAR; MUSTAFA; JAMIL, 2013). A termoestabilidade é altamente variável e depende do organismo. Muitas enzimas produzidas por fungos mesófilos não são termoestáveis, o que pode limitar a sua aplicação industrial. As enzimas termoestáveis são interessantes porque a elevação da temperatura de reação (até a um determinado limite), em geral, reduz o risco de contaminação microbiana e pode aumentar a taxa de reação (KNOB; TERRASAN; CARMONA, 2010; KUMAR; SHUKLA, 2016).

Dado o exposto e devido a sua importância biotecnológica, vários trabalhos têm sido realizados para isolamento, produção, purificação e caracterização de $\beta$ xilosidases.

\subsection{3 - Arabinofuranosidases}

As $\alpha$-L-arabinofuranosidases (ABFs - EC 3.2.1.55) são enzimas acessórias que clivam as ligações $\alpha$-L-arabinofuranosidicas entre os resíduos de arabinofuranose e xilose da cadeia central da xilana. As ABFs atuam sinergisticamente com outras hemicelulases e pectinases para a completa hidrólise da fração de hemicelulose e pectina (NUMAN; BHOSLE, 2006). Essas enzimas já foram purificadas de bactérias, fungos e plantas (FRITZ et al., 2008; LEE et al., 2003; RAWEESRI; RIANGRUNGROJANA; PINPHANICHAKARN, 2008; YAN et al., 2012).

Diferente das XYLs que, normalmente, se encontram aderidas a célula, as ABFs são enzimas extracelulares (LAURUENGTANA; PINPHANICHAKARN， 2006; 
MARTÍNEZ et al., 2006; SAHA; BOTHAST, 1998). As ABFs produzidas por diferentes micro-organismos apresentam grande variação em relação ao $\mathrm{pH}$ e temperatura ótimos, sendo estes verificados entre $\mathrm{pH} 3,0$ e 7,0 e temperaturas de 25 a $75^{\circ} \mathrm{C}$ (LAGAERT et al., 2014). A produção de ABFs é influenciada pela fonte de carbono e composição do meio de cultura, sendo que várias dessas fontes, incluindo açúcares monoméricos e polissacarídeos complexos, como resíduos agroindustriais, têm sido avaliadas para a produção e indução dessas enzimas (LAURUENGTANA; PINPHANICHAKARN, 2006; SAHA; BOTHAST, 1998)

As $\mathrm{ABFs}$ podem catalisar a hidrólise do terminal não redutor dos resíduos $\alpha$-L1,2, $\alpha$-L-1,3 e $\alpha$-L-1,5-arabinofuranosil de diferentes polissacarídeos e oligossacarídeos (SAHA, 2000). As ABFs tem sido classificadas, com base na sua sequência de aminoácidos, em seis famílias das glicosil hidrolases (3, 43, 51, 54, 62 e 93) (http://www.cazy.org/ Glycoside-Hydrolases.html) (HENRISSAT; DAVIES, 1997). Algumas ABFs tem sido relatadas como sendo enzimas bifuncionais, apresentando atividades de XYLs e ABF, sendo encontradas, principalmente, em membros da família GH43 (LEE et al., 2003; RAVANAL; CALLEGARI; EYZAGUIRRE, 2010; WAN et al., 2007). Assim como outras glicosil hidrolases, as ABFs podem mediar a clivagem da ligação glicosídica através da catálise ácido/base por meio de dois principais mecanismos, por retenção total ou inversão da configuração anomérica (LAGAERT et al., 2014).

Dependendo da especificidade do substrato, as ABFs podem ser classificadas em três tipos: Tipo A é ativa sobre arabinooligossacarídeos e sobre o substrato sintético de $\rho$-nitrofenilo ( $\rho \mathrm{NP}$ ) (não ativa em todos os polímeros), o tipo B catalisa a hidrólise de arabinooligossacarídeos, $\rho \mathrm{NP}$ e polímeros ramificados (todos os polímeros) e tipo $\mathrm{C}$ só é ativa em arabinoxilana, não ativa no $\rho N P$ (BELDMAN et al., 1997).

As ABFs podem ainda ser divididas em três subclasses: Subclasse (1) que inclui enzimas que são capazes de liberar arabinose ligados à xilose da cadeia central por simples e dupla substituição e são capazes de hidrolizar o substrato sintético $\rho N P$. Subclasse (2) inclui enzimas que hidrolisam resíduos de arabinose a partir do carbono C2 ou C3 ligadas a um único resíduo de xilose e não hidrolisam pNP e Subclasse (3) que inclui enzimas que são capazes de liberar apenas os resíduos de arabinose do carbono C3 de duplas substituições, mas não hidrolisam pNP. As arabinoxilanas contêm simples e duplos resíduos de xilose substituídos (NUMAN; BHOSLE, 2006). 
As substituições de L-arabinofuranosidio sobre a xilana podem inibir a ação das enzimas que degradam a xilana, impedindo assim a completa hidrólise da hemicelulose em unidades de xilose (RAHMAN et al., 2003). Logo, estudos com ABFs são justificados pois essas enzimas representam um potencial limitante da velocidade da degradação da lignocelulose a partir de resíduos agrícolas (WILKENS et al., 2016). A adição sequencial de uma ABF (GH43) seguido por uma endo-xilanase (GH11), ambas de Humicola insolens, aumentou a eficiência de hidrólise da xilana de bétula (birchwood) e da xilana de madeira de faia (beechwood), onde o grau de sinergia foi de 1,21 (YANG et al., 2015).

As ABFs têm atraído o interesse de pesquisas devido às suas potenciais aplicações industriais, sendo empregadas sinergicamente com outras hemicelulases em vários processos. Dentre as aplicações biotecnológicas das ABFs, destaca-se a produção de compostos medicinais importantes, melhoria dos sabores do vinho, da qualidade do pão, na indústria de polpa celulósica, aumento da digestibilidade de ração animal, clarificação de suco de fruta, produção de bioetanol e a síntese de oligossacarídeos (LEE et al., 2003)

\section{3 - Produção de hemicelulases em Pichia pastoris}

Os fungos têm sido utilizados por anos para a produção de enzimas industrialmente importantes (KIRIKYALI; CONNERTON, 2015). Ocorre que o isolamento dessas enzimas a partir do secretoma do fungo pode requerer muitos passos e aumentar os custos da produção (KRACHER et al., 2014). Logo, a produção de enzimas recombinantes que são industrialmente importantes representa uma alternativa para seleção de características úteis em escala comercial. Com esse objetivo, muitos genes de XYNs, XYLs e ABFs de diferentes micro-organismos foram clonados e expressos em diversos hospedeiros, incluindo $P$. pastoris, com vistas à produção, caracterização e à aplicação em diferentes áreas (KUMAR; SHUKLA, 2016; LAGAERT et al., 2014; MUSTAFA et al., 2016).

A levedura metilotrófica $P$. pastoris tem emergido como um dos sistemas mais comuns e eficazes para a produção de proteínas recombinantes (AHMAD et al., 2014). O sistema de expressão heteróloga de $P$. pastoris apresenta muitas vantagens para a produção de proteínas recombinantes eucariotas, bem como uma ferramenta poderosa para a fermentação em escala industrial (SPOHNER et al., 2015).

Algumas dessas propriedas favoráveis incluem: altos níveis de expressão sob o 
controle do promotor $A O X 1$ que permite a transcrição dos produtos gênicos a ele fusionados sob regulação de metanol; integração do cassete de expressão no genoma da levedura de forma estável; elevados níveis de produtividade em meio quase livre de proteínas; facilidade de manipulação genética e a capacidade para manipular proteínas secretadas que podem ser purificadas a partir de meio de crescimento sem a colheita das células de levedura. Além disso, ela possui o status "GRAS" (Generally Regarded As Safe) reconhecido pela FDA (American Food and Drug Administration) (CEREGHINO; CREGG, 2000).

Outras vantagens de $P$. pastoris incluem crescimento rápido em temperaturas que podem variar de $15^{\circ} \mathrm{C}$ a $30^{\circ} \mathrm{C}$ e uma ampla tolerância a pHs que variam de $3,0-7,0$ (YU et al., 2014). Dados esses motivos, essa levedura se torna uma escolha interessante para expressão de enzimas lignocelulolíticas e outras proteínas eucarióticas que requerem modificações pós-traducionais para atingir a conformação correta, estabilidade e atividade (MUSTAFA et al., 2016).

Além disso, já é descrito na literatura que $P$. pastoris pode ser utilizada para secretar enzimas lignocelulolíticas em grandes quantidades (LI et al., 2015; WONGWISANSRI et al., 2013; XIA et al., 2015), podendo ser dispensada a etapa de purificação das proteínas recombinantes, o que pode contribuir para redução de etapas e custos durante a produção de enzimas lignocelulolíticas, particularmente para aplicação em escala industrial.

Existem diversas linhagens de $P$. pastoris, o que permite escolher um fenótipo adequado para cada aplicação. Muitas vezes, é necessário verificar qual linhagem é a mais adequada para a enzima que se deseja produzir. As linhagens SMD1168, KM71 e GS115 são deficientes na produção de histidina pelo fato do gene HIS4 (codifica a enzima histidinol desidrogenase: uma das enzimas da via biossintética de histidina) apresentar uma mutação que inativa a enzima HIS4, gerando o fenótipo His-, a sua utilização permite que os transformantes sejam selecionados com base em sua capacidade de crescer em meio de cultura sem histidina, o que propicia o uso de vetores contendo este gene para transformação e seleção de clones por complementação auxotrófica em meio sem histidina (CEREGHINO; CREGG, 2000).

A linhagem SMD1168 é deficiente para produção da enzima vacúolo peptidase A (pep4). Esta enzima é responsável pela ativação da carboxipeptidase Y e protease B1 e, portanto, a SMD1168 também é deficiente na produção dessas proteases. Estas 
características são particularmente importantes, pois proteases são responsáveis, em alguns casos, pela degradação das proteínas heterólogas (YU et al., 2014).

A levedura $P$. pastoris foi reclassificada dentro de um novo gênero denominado de Komagataella. Este gênero foi acrescido de três espécies, K. pastoris, K. phaffii e $K$. pseudopastoris. As linhagens GS115 e X33 passaram a ser conhecidas como K. phaffii, enquanto as linhagens da série SMD são classificadas dentro da espécie $K$. pastoris (KURTZMAN, 2009).

Nas leveduras metilotróficas, o metanol é inicialmente oxidado nos peroxissomas pela ação das enzimas álcool oxidase (AO), catalase e dihidroxiacetona sintase. Durante o crescimento de P. pastoris em metanol, a enzima AO constitui a proteína mais abundante da célula chegando a representar $30 \%$ das proteínas celulares totais (CREGG et al., 2000).

A expressão da $\mathrm{AO}$ é induzida na presença de metanol e reprimida na presença de glicerol ou glicose. A enzima AO é codificada por dois genes distintos: AOX1 $(95 \%$ da atividade de AO) e $A O X 2$ (5\% da atividade de AO). Em células expostas ao metanol como única fonte de carbono, o início da transcrição a partir do promotor de $A O X 1$ é altamente eficiente e comparável aos promotores dos genes expressos da via glicolítica. O promotor de $A O X 1$ é controlado pela fonte de carbono adicionada ao meio de cultura, a indução da expressão de proteínas heterólogas em P.pastoris é facilmente obtida em todas as escalas, desde frascos até grandes fermentadores (CEREGHINO; CREGG, 2000)

Os mecanismos pelos quais ocorrem a transformação e a integração em $P$. pastoris são por adição ou por substituição gênica (Cregg et al., 1993). A forma com a qual o cassete de expressão se integra no genoma de $P$. pastoris possibilita caracterizar três fenótipos diferentes, que se relacionam com a habilidade da levedura em metabolizar metanol. Tais fenótipos são: Mut+ (Methanol Utilization Plus), nos quais as linhagens hospedeiras apresentam os genes $A O X 1$ e $A O X 2$ funcionais no seu genoma e possuem crescimento que se aproxima daquele apresentado pela levedura selvagem, o fenótipo $\mathrm{Mut}^{\mathrm{S}}$ (Methanol Utilization Slow), dependente da fraca transcrição do gene $A O X 2$ uma vez que possui o gene $A O X 1$ não funcional, e por fim o fenótipo Mut(Methanol Utilization Minus) que possui os dois genes $A O X$ inativos impossibilitando a metabolização de metanol, e, não crescendo na ausência de outras fontes de carbono.

Quando o cassete de expressão se integra no lócus do gene $A O X 1$, o gene é subtituído pelo cassete de expressão e o transformante apresenta crescimento lento 
quando cultivado em meio com metanol como única fonte de carbono (fenótipo $\mathrm{Mut}^{\mathrm{s}}$ Methanol Utilization Slow) (Fig. 3 A) . No caso da integração ocorrer por adição no lócus de AOX1, os genes AOX1 e AOX2 são mantidos no genoma e o transformante apresenta crescimento normal em meio com metanol (fenótipo $\mathrm{Mut}^{+}$- Methanol Utilization Plus) (Fig. 3 B). Algumas linhagens, como SMD1165, SMD1168 e GS115, apresentam a capacidade de utilizar metanol como a linhagem selvagem X-33, fenótipo este chamado de $\mathrm{Mut}^{+}$.

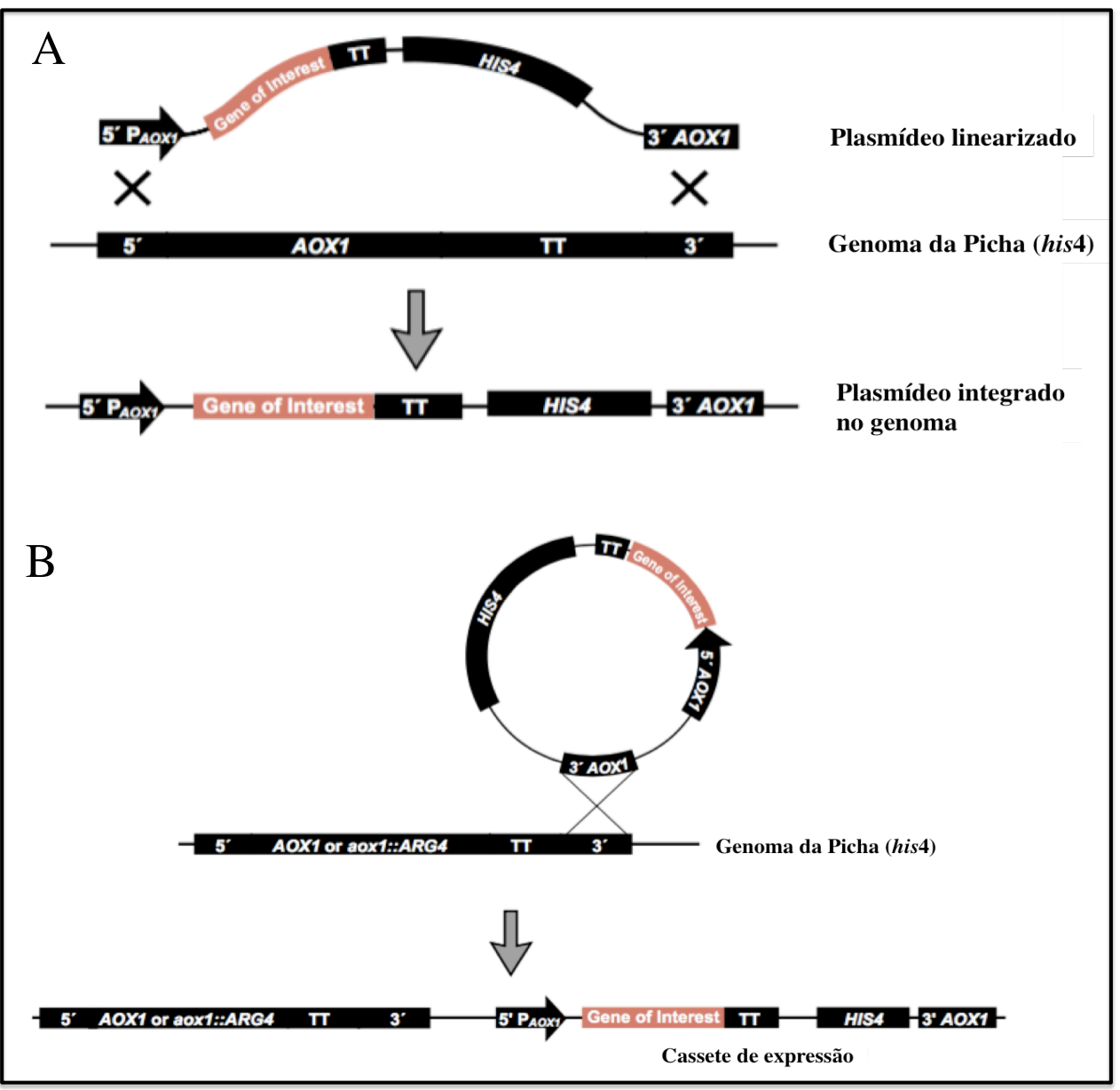

Figura 3 - Mecanismos de integração do cassete de expressão no genoma de $P$. pastoris utilizados no presente trabalho. A - Substituição do gene AOX1 e B - Adição em AOX1. Adaptado do manual "Pichia expression Kit K1710-01 - Invitrogen".

Para a otimização da expressão é importante se considerar o fenótipo Mut. Para a secreção de proteínas, qualquer um dos fenótipos, $\mathrm{Mut}^{+}$ou $\mathrm{Mut}^{\mathrm{S}}$ podem ser usados, sendo que o ideal é testar a expressão em ambas as linhagens e fenótipos (AHMAD et al., 2014). Uma vantagem do fenótipo $\mathrm{Mut}^{\mathrm{s}}$ é que a cultura não é tão sensível ao 
metanol residual no meio de cultura em relação ao fenótipo $\mathrm{Mut}^{+}$, e portanto, o processo de aumento de escala pode ser mais fácil (COS et al., 2005).

O rendimento da produção de uma proteína heteróloga em $P$. pastoris depende das condições de crescimento e dos parâmetros do processo de cultivo, bem como, de fatores que influenciam a expressão do gene (e secreção da proteína) e a fisiologia da linhagem hospedeira (LOOSER et al., 2015). Além disso, a concepção de um sistema ótimo de produção depende das características da proteína que se deseja produzir como, por exemplo, a toxicidade celular, a estabilidade e a sensibilidade a ação de proteases (MACAULEY-PATRICK et al., 2005).

Como já mencionado, a levedura $P$. pastoris tem demonstrado capacidade de produzir enzimas lignocelulósicas em quantidades que são requeridas para aplicações industriais. Além disso, as enzimas produzidas por ela apresentam características de melhor estabilidade, devido à modificações pós-traducionais como a glicosilação. De maneira geral, as enzimas glicosiladas por P. pastoris exibem melhor estabilidade térmica do que enzimas não glicosiladas (ERGÜN; ÇALIK, 2016).

Todos os aspectos abordados, característicos dessa levedura, podem contribuir para o seu potencial em reduzir custos durante a produção de enzimas lignocelulolíticas. Além disso, os altos níveis de produção comparados com as mesmas enzimas expressas em outros hospedeiros, fazem essa levedura ser uma boa escolha para à expressão heteróloga de enzimas lignocelulolíticas.

A Tabela 2 mostra algumas hemicelulases (XYNs, XYLs e ABFs) fúngicas produzidas por P. pastoris, indicando as linhagens utilizadas, promotor e redimento da produção. 
Tabela 2 - Exemplos de hemicelulases fúngicas produzidas por $\boldsymbol{P}$. pastoris (linhagens e promotor).

\begin{tabular}{|c|c|c|c|c|c|}
\hline & Doador & Linhagem & Promotor & Produção & Referência \\
\hline \multirow{4}{*}{ 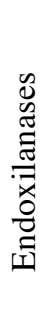 } & $\begin{array}{c}\text { Aspergillus } \\
\text { usamii }\end{array}$ & X33 & $\mathrm{AOX}$ & $33500 \mathrm{U} / \mathrm{mL}$ & (WANG; LI; LIU, 2016) \\
\hline & $\begin{array}{l}\text { Trichoderma } \\
\text { reesei }\end{array}$ & X33 & $\mathrm{AOX}$ & $9,88 \mathrm{~g} / \mathrm{L}$ & (LI et al., 2015) \\
\hline & H.insolens & GS115 & $\mathrm{AOX}$ & $382 \mathrm{U} / \mathrm{mg}$ & (SHI et al., 2015) \\
\hline & Bispora antennata & GS115 & $\mathrm{AOX}$ & $248,2 \mathrm{U} / \mathrm{mg}$ & (LIU et al., 2015) \\
\hline \multirow{4}{*}{ 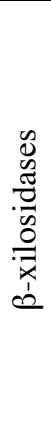 } & H.insolens & GS115 & $\mathrm{AOX}$ & $\begin{array}{c}100 \mathrm{mg} / \mathrm{L} \\
(11,6 \mathrm{U} / \mathrm{mg})\end{array}$ & (XIA et al., 2015) \\
\hline & $\begin{array}{c}\text { Aspergillus } \\
\text { niger ASKU28 }\end{array}$ & Y11430 & $\mathrm{AOX}$ & $5,7 \mathrm{~g} / \mathrm{L}$ & (CHOENGPANYA et al., 2015) \\
\hline & $\begin{array}{c}\text { Thermomyces } \\
\text { lanuginosus SSBP }\end{array}$ & SMD1 168 & GAP & $60 \mathrm{U} / \mathrm{mL}$ & (GRAMANY et al., 2015) \\
\hline & $\begin{array}{l}\text { Paecilomyces } \\
\text { thermophila }\end{array}$ & KM71 & $\mathrm{AOX}$ & $0,22 \mathrm{mg} / \mathrm{L}$ & (JUTURU; WU, 2013) \\
\hline \multirow{4}{*}{ 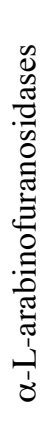 } & H.insolens & GS115 & $\mathrm{AOX}$ & $0,62 \mathrm{U} / \mathrm{mL}$ & (YANG et al., 2015) \\
\hline & $\begin{array}{c}\text { Aspergillus } \\
\text { nidulans FGSC } \\
\text { A4 }\end{array}$ & X33 & $\mathrm{AOX}$ & $1,66 \mathrm{U} / \mathrm{mg}$ & (WILKENS et al., 2016) \\
\hline & $\begin{array}{l}\text { Aspergillus } \\
\text { fumigatus }\end{array}$ & GS115 & $\mathrm{AOX}$ & $\begin{array}{c}\mathrm{ABF} 1-7,7 \\
\mathrm{U} / \mathrm{mL} \\
\mathrm{ABF} 2-22 \\
\mathrm{U} / \mathrm{mL}\end{array}$ & $\begin{array}{c}\text { (PÉREZ; EYZAGUIRRE, } \\
\text { 2016) }\end{array}$ \\
\hline & $\begin{array}{l}\text { Pleurotus } \\
\text { ostreatus }\end{array}$ & X33 & $\mathrm{AOX}$ & $180 \mathrm{mg} / \mathrm{L}$ & (AMORE et al., 2012) \\
\hline
\end{tabular}

\section{4 - Fungos filamentosos produtores de hemicelulases}

Várias pesquisas tem sido realizadas no sentido de prospectar micro-organismos produtores de hemicelulases de diversos hábitats como adubo, madeira em decomposição, resíduos lignocelulósicos e agrícolas (SHARMA; VAID; BAJAJ, 2015). Novos micro-organismos produtores dessas enzimas podem ser isolados a partir de diversas amostras ambientais usando, por exemplo, a abordagem da metagenômica, que é uma área que tem emergido dentro da biotecnologia (NAZIR, 2016).

Os fungos filamentosos são grandes produtores de enzimas extracelulares e, geralmente, apresentam fácil cultivo. Entre os fungos filamentosos, o gênero Aspergillus e Trichoderma são amplamente utilizados para a produção de enzimas hidrolíticas e, normalmente, são utilizados como fonte de enzimas comerciais (KUMAR; SHUKLA, 2016). Entre os fungos produtores de enzimas, o gênero Humicola tem sido reportado como produtor de celulases e hemicelulases 
termoestáveis. Alguns genes de celulases e hemicelulases de H. insolens e H. grisea foram sequenciados e caracterizados, sendo verificado que estas espécies apresentam genes de celulase e xilanases homólogos (SOUZA et al., 2014).

\subsection{1 - Humicola grisea var. Thermoidea}

O fungo $H$. grisea var. thermoidea foi isolado de compostagem na Universidade Federal de Viçosa (CHAVES, 1982). É caracterizado como um fungo aeróbico que sobrevive em temperaturas que variam de 20 a $50{ }^{\circ} \mathrm{C}$, apresentando crescimento ótimo entre 40 e $42{ }^{\circ} \mathrm{C}$. Trata-se de um fungo termofílico, que tem demonstrado a capacidade de secretar várias enzimas termoestáveis como celulases (DE AZEVEDO et al., 1990; OLIVEIRA et al., 2013), $\beta$ - glicosidases (FERREIRA FILHO, 1996; PERALTA et al., 1997), xilanases (DÜSTERHÖFT et al., 1997; LUCENANETO; FERREIRA-FILHO, 2004), $\beta$-xilosidases (IEMBO et al., 2006) e feroluil esterases (MANDALARI et al., 2008).

O grupo de pesquisa do laboratório de biotecnologia de fungos da Universidade Federal de Goiás (UFG) tem focado na caracterização de enzimas produzidas por $H$. grisea, bem como, na caracterização de genes com vistas a produção de enzimas com interesse biotecnológico. Algumas dessas enzimas já foram empregadas com sucesso na bioconversão de materiais lignocelulósicos (DE-PAULA; RAMOS; DE OLIVEIRA AZEVEDO, 1999). O fungo também pode ser utilizado como um doador do genes heterólogos para a produção de enzimas industriais e para complementar coquetéis enzimáticos (BENOLIEL et al., 2010).

O fungo H. grisea é capaz de secretar celulases e hemicelulases quando cultivado na presença de substratos lignocelulósicos como, por exemplo, bagaço de cana-de-açúcar (BCA), sabugo de milho (SM), farelo de trigo (FT), palha de cereal (PC) e palha de arroz (PA) (CARVALHO, W. R., 2008; RAMOS, G. P., 2010).

Quando cultivado em palha de cereal moída (Ball-Milled Straw-BMS) e BCA , o fungo $H$. grisea foi capaz de secretar várias enzimas hidrolíticas, dentre elas destacase a produção de uma proteína com cerca de 49,6 kDa que corresponde a uma celobiohidrolase (CBH1.2) (DE PAULA; POÇAS-FONSECA; DE OLIVEIRA AZEVEDO, 2003). De acordo com a fonte de carbono no meio de cultura, genes de $H$. grisea que codificam celobiohidrolases são diferencialmente expressos, como os genes cbh1.1 e cbh1.2 (POÇAS-FONSECA et al., 2000). O gene da CBH1.2 de H. grisea foi expresso na levedura metilotrófica $P$. pastoris e a enzima secretada apresentou massa 
molecular estimada de $47 \mathrm{kDa}$, temperatura ótima de $60^{\circ} \mathrm{C}, \mathrm{pH}$ ótimo de 8,5 e atividade exo e endoglucanase, sendo ativa contra papel de filtro Whatman $\mathrm{n}^{\circ} 1$, carboximetilcelulose (CMC) e avicel (Sigma) (OLIVEIRA et al., 2013).

$\mathrm{Na}$ presença de farelo de trigo (FT) como fonte de carbono, o fungo $H$. grisea é capaz de secretar xilanases, destacando-se uma endoxilanase de $23 \mathrm{kDa}$, que foi caracterizada e purificada apresentando temperatura ótima de $65^{\circ} \mathrm{C}, \mathrm{pH}$ ótimo de $5,5 \mathrm{e}$ pI de 6,5 (CARVALHO, W.R., 2003). O gene (hxyn2) que codifica essa endoxilanase de $23 \mathrm{kDa}$ foi isolado e expresso no fungo Trichoderma reesei, sendo ativa contra xilana "oat spelt" (DE FARIA et al., 2002). Esse gene também foi expresso em $P$. pastoris com o objetivo de realizar a purificação e caracterização enzimática. A enzima denominada de HXYN2 foi purificada e apresentou pH ótimo de 6,5, temperatura ótima de $60{ }^{\circ} \mathrm{C}$, alta estabilidade na faixa de $\mathrm{pH}$ entre $5,5-7,5$, meia-vida de 20 min a $60^{\circ} \mathrm{C}$ e valores de 7,9 mg/mL e 235,4 $\mu \mathrm{mol} /(\min . \mathrm{mL})$ para $\mathrm{k}_{\mathrm{m}}$ e Vmáx (CARVALHO, W. R., 2008).

Para o estudo da endoxilanase HXYN2, um modelo foi construído por homologia com a sequência de outras endoxilanases e mostrou que essa enzima pertence à família 11 das glicosil hidrolases e esse modelo mostrou que a estabilidade térmica da proteína HXYN2, em comparação com xilanases mesófilas, pode ser explicado por uma rede eletrostática adicional e resíduos aromáticos expostos (DE FREITAS et al., 2003).

A enzima recombinante HXYN2 foi utilizada em um mix enzimático e foi aplicada no processo de hidrólise enzimática da fração de hemicelulose de BCA e palha de cana-de-açúcar (PCA) e SM. O sobrenadante de cultura do fungo H. grisea cultivado em BCA foi suplementado com a endoxilanase HXYN2 e observou-se uma taxa de conversão da fração de hemicelulose de $42,8 \%$ para o SM, de 9,6 \% para BCA e $20 \%$ para PCA (CARVALHO, W. R., 2008). A enzima HXYN2 se mostrou eficiente no processo de biobranqueamento de polpa de celulose (MORIYA; GONÇALVES; FARIA, 2005) e em ensaios de panificação (BASTOS, F. M., 2008).

Além das enzimas HXYN2 e CBH1.2, outras enzimas de $H$. grisea foram expressas de forma heteróloga como BGLs (BENOLIEL et al., 2010; TAKASHIMA et al., 1999a), EGLs (EGL2, EGL3 e EGL4) (TAKASHIMA et al., 1996, 1999b), e uma CBH (CBH 1) (TAKASHIMA et al., 1996). 
RAMOS (2010) analisou a produção de celulases e xilanases pelo fungo $H$. grisea cultivado em BCA, FT, SM e PA. Os resultados demonstraram que o BCA foi o melhor indutor da produção de celulases enquanto que o FT o melhor indutor da produção de xilanases. Em ensaios de zimograma analisou-se o perfil de celulases e xilanases secretadas e os resultados demonstraram que o fungo secretou diferentes tipos de celulases e xilanases quando cultivado com esses substratos. Quando cultivado na presença de bagaço de malte e FT, o fungo $H$. grisea secretou, além de xilanases, feroliul esterases com 0,47 U/mL e 0,33 U/mL, respectivamente (MANDALARI et al., 2008).

Além de xilanases e celulases, o $H$. grisea é capaz de produzir duas $\beta$ xilosidases quando crescido com xilana oat spelt como única fonte de carbono, uma periplasmática e outra associada ao micélio. A primeira, localizada no periplasma, se apresentou sob forma monomérica com $43 \mathrm{kDa}$. $\mathrm{O} \mathrm{pH}$ ótimo e temperatura foram de 6,0 e $50{ }^{\circ} \mathrm{C}$, respectivamente (DE ALMEIDA et al., 1995). A segunda, associada ao micélio, apresentou massa molecular de $50 \mathrm{kDa}$, foi purificada e caracterizada, apresentando $\mathrm{pH}$ e temperatura ótima de 6,5 e $50{ }^{\circ} \mathrm{C}$, respectivamente (IEMBO et al., 2006).

O sobrenadante de cultura de $H$. grisea quando cultivado na presença de FT e BCA foi utilizado em ensaios de hidrólise da fração de xilana do BCA pré-tratado por explosão a vapor. Para melhorar a hidrólise, os sobrenadantes de cultura foram suplementados com as enzimas recombinantes: HXYN2, CBH1.2 e com uma $\beta$ xilosidase recombinante (XYNB2) da bactéria Caulobacter crescentus (GRACIANO et al., 2012). Foi demonstrando que as enzimas recombinantes agiram em conjunto aumentando a eficiência de conversão da xilana a xilose (Dados ainda não publicados). Entretanto, os experimentos de planejamento fatorial demonstraram que o uso da maior concentração da $\beta$-xilosidase pode aumentar a conversão de xilana a xilose (QING; WYMAN, 2011).

\subsection{2 - Penicillium purpurogenum}

A maioria dos estudos com fungo filamentoso P. purpurogenum são focados na produção de colorantes naturais utilizados na indústria de alimentos, cosméticos e farmacêutica (TORRES et al., 2016). Entretanto, tem sido demonstrado a importância desse fungo para produção de enzimas lignocelulolíticas com interesse biotecnológico e que podem ser aplicadas para outros fins. 
O fungo $P$. purpurogenum, que é conhecido como fungo da podridão-mole, também é capaz de crescer sobre diferentes resíduos lignocelulósicos como única fonte de carbono, sendo capaz de secretar no meio de cultura várias enzimas lignocelulolíticas com potencial biotecnológico (NAVARRETE; CALLEGARI; EYZAGUIRRE, 2012).

P. purpurogenum secreta várias isoformas de enzimas xilanolíticas, incluindo quatro arabinofuranosidases (ABF1, $\mathrm{ABF} 2, \mathrm{ABF} 3$ e $\mathrm{ABF} 4)$. Essas enzimas foram purificadas, caracterizadas e sequenciadas. A ABF1 pertence a família 54 das glicosil hidrolases, a ABF2 a família 51, a ABF3 a família 43 e a ABF4 a família 54 (CARVALLO et al., 2003; FRITZ et al., 2008; RAVANAL; CALLEGARI; EYZAGUIRRE, 2010; RAVANAL; EYZAGUIRRE, 2015). P. purpurogenum é o primeiro fungo com quatro $\mathrm{ABFs}$ descritas e caracterizadas.

A ABF3 é uma enzima bifuncional que apresenta atividade de $\alpha$-Larabinofuranosidase e $\beta$-xilosidase, apresenta $\mathrm{pH}$ ótimo de 5,0 e temperatura ótima de $50{ }^{\circ} \mathrm{C}$. O gene ABF3 foi clonado e expresso em P. pastoris e a enzima heteróloga apresentou as mesmas características bioquímicas que a enzima nativa. Além disso, a enzima recombinante ABF3 foi aplicada com sucesso na melhoria da qualidade do sabor do vinho. Essa enzima mostrou ser capaz de tolerar o $\mathrm{pH}$ ácido e altas concentrações de etanol durante a produção de vinhos (RAVANAL et al., 2013).

Além das ABFs, $P$. purpurogenum produz uma XYL pertencente a família GH43 que já teve o seu gene expresso em P. pastoris e apresentou atividade sobre arabinoxilana de trigo e xilooligosacarídeos (RAVANAL et al., 2013, p. 43). Duas endo-xilanases, XynA e XynB, também já foram purificadas, caracterizadas e sequenciadas, sendo uma pertencente a família GH10 e outra a GH11 (CHÁVEZ et al., 2002).

Além de secretar enzimas que degradam hemicelulose, foi reportado que $P$. purpurogenum produz uma pectina liase, que foi produzida por P. pastoris e caracterizada (PÉREZ-FUENTES; RAVANAL; EYZAGUIRRE, 2014). Em um estudo do secretoma do fungo, foram identificados complexos multi-enzimáticos que são compostos por arabinofuranosidases, acetil-xilana esterases, feruloil-esterases, $\beta$ glicosidases e xilanases. A expressão e a montagem destes complexos enzimáticos dependem da fonte de carbono utilizada (GONZALEZ-VOGEL et al., 2011). 


\section{5 - Bioconversão da fração de hemicelulose}

A hidrólise da fração de hemicelulose é importante para alcançar rendimentos desejados de açúcares fermentescíveis. A hemicelulose é mais facilmente hidrolisada em comparação com celulose devido a sua estabilidade térmica e química que é, normalmente, inferior a da celulose devido à baixa cristalinidade e menor grau de polimerização. Os açúcares dominantes nas hemiceluloses são manose em madeiras macias (softwoods) e xilose em madeiras duras (hardwoods) e resíduos agrícolas (GÍRIO et al., 2010).

O processo de pré-tratamento é requerido com o objetivo de solubilização e separação de um ou mais componentes da biomassa vegetal. Podem ser utilizadas as seguintes técnicas: físicas (trituração e hidrotermólise), químicas (ácida, alcalina, solventes, ozônio), físico-químicas (explosão a vapor, explosão com amônia) e biológicas, entre outras. Em cada opção a biomassa é reduzida em tamanho e sua estrutura física é desestruturada (KHOO, 2015; MOSIER et al., 2005).

O objetivo final, de qualquer tecnologia de pré-tratamento para produção de etanol, é conseguir um equilíbrio entre as taxas de produção de etanol e o custo de produção (TAO et al., 2011). Para isso, as condições ideais de pré-tratamento devem ser analisadas visando recuperação máxima de açúcares solúveis, sendo necessário verificar seus impactos sobre as matérias-primas, vantagens e desvantagens, bem como os rendimentos de fermentação (AGBOR et al., 2011).

Dependendo do tipo do pré-tratamento empregado, algumas das hemiceluloses, principalmente a xilana de resíduos agrícolas e de madeira, permanecem associadas com a fração insolúvel da celulose. Em função disso, a hemicelulose solúvel podem inibir a atividade das celulases. $\mathrm{O}$ acesso limitado pelas celulases na celulose é um fator que exige a utilização de doses relativamente elevadas de enzimas para atingir a hidrólise da celulose eficaz (ARANTES; SADDLER, 2011).

A adição de xilana birchwood reduz a hidrólise enzimática realizada pelas celulases (endoglucanases e celobiohidrolases) de palha de trigo e avicel, diminuindo drasticamente a formação de celobiose (ZHANG; TANG; VIIKARI, 2012). Um dos principais efeitos benéficos da suplementação de xilanases durante a sacarificação de biomassa é a acessibilidade melhorada à celulose como resultado da solubilização da xilana (HU; ARANTES; SADDLER, 2011).

Durante a hidrólise da lignocelulose, muitas enzimas com diferentes atividades são requeridas para garantir a hidrólise eficiente das frações de celulose e 
hemicelulose. Estes estudos incluem a utilização de misturas com diferentes celulases, com atividades de endo e exoglucanases, (FANG; XIA, 2015), $\beta$-glicosidases (DOTSENKO et al., 2015), endo-xilanases (GONÇALVES et al., 2015), feroluil esterases (ZHANG et al., 2015), expansinas (BUNTERNGSOOK et al., 2015) e enzimas oxidativas (SUN et al., 2015).

$\mathrm{O}$ sinergismo entre hemicelulases (arabinofuranosidase (ABF - GH62), endo1,4-beta-xilanase (XYN- GH10) e uma pectina esterase (PEC- CE8)) de Aspergillus aculeatus produzidas em $P$. pastoris jutamente com celulases comerciais de T. reesei (Accellerase ${ }^{\circledR} 1500$-ACR) foi avaliado durante a hidrólise de palha de arroz pré tratada, em que foi realizado um planejamento experimental para avaliar a ação das enzimas. A ação cooperativa da ABF, XYN e PEC conduziu a um aumento de 47,3\% do rendimento de glicose liberada comparada com a hidrólise com apenas as celulases comerciais (ACR) (LAOTHANACHAREON et al., 2015).

Proteínas acessórias também podem melhorar a eficiência da hidrólise. Um exemplo disso são as expansinas, que são proteínas de parede celular vegetal que clivam as ligações de hidrogênio, afrouxando a fibra e aumentando a acessibilidade de outras enzimas aos polissacarídeos (COSGROVE et al., 2002). Proteínas relacionadas a expansina já foram identificadas em bactérias e fungos, e ao que parece elas colaboram com a invasão microbiana no corpo da planta. O efeito da suplementação com expansinas bacterianas em coquetéis enzimáticos, contendo celuloses e hemiceluloses durante a hidrólise mostrou ser eficiente, apresentando o maior efeito em arabinoxilana com até 12,2 vezes mais açúcares redutores do que a reação com as enzimas sozinhas (BUNTERNGSOOK et al., 2015).

O sinergismo entre enzimas que atuam na cadeia principal e enzimas acessórias desramificadoras também é necessário para a completa desconstrução da xilana. Dentre as enzimas acessórias que removem ramificações da xilana estão as $\alpha$-glicuronidases, $\alpha$-L-arabinofuranosidase, feruloil e p-cumaroil esterases e acetil xilana esterases (SUN et al., 2015).

O sinergismo entre enzimas é observado quando a quantidade de produtos liberados por duas ou mais enzimas que atuam em conjunto seja superior à soma dos produtos liberados pela ação das enzimas isoladamente. Van Dyk \& Pletschke (2012) revisaram os três tipos de sinergismo que já foram identificados: homosinergismo, heterosinergismo e antisinergia. A homosinergia ocorre entre enzimas que clivam a 
cadeia principal, enquanto heterosinergia ocorre entre enzimas que clivam a cadeia principal e enzimas desramificadoras. A antisinergia é o termo usado quando uma enzima inibe a ação de uma outra enzima.

O grau de sinergia é uma medida para determinar se uma enzima está contribuindo para a capacidade de outra enzima atuar sobre o substrato. Um grau de sinergia de 1 ou menos é uma indicação de não houve sinergia entre enzimas, ou que as enzimas poderiam estar competindo pelo substrato. Valores acima de 1, podem indicar que as enzimas trabalham em sinergismo. A medida do grau de sinergia pode ser baseada na formação de produto, taxa de reação ou conversão do substrato. Algumas informações podem ser obtidas a partir dos valores gerados pela medida do grau de sinergismo, como informações sobre a estrutura e mecanismos de degradação de um substrato e sobre o mecanismo de ação das enzimas (VAN DYK; PLETSCHKE, 2012)

Os efeitos sinérgicos entre duas enzimas podem variar quando elas são utilizadas simultaneamente ou sequencialmente para hidrolisar um substrato. Vários trabalhos mostram que as enzimas que atuam na cadeia principal apresentam a sua atividade melhorada após a remoção dos substituintes pelas enzimas desrramificadoras (HU; ARANTES; SADDLER, 2011; RAWEESRI; RIANGRUNGROJANA; PINPHANICHAKARN, 2008; WILKENS et al., 2016; YANG et al., 2015). Para isso, é comum utilizar as enzimas desramificadoras como um tipo de pré-tratamento antes da adição da enzima para clivagem da cadeia principal em uma etapa sequencial, o que pode alterar a liberação de açúcares redutores e consequentemente a sinergia.

O maior grau de sinergia foi obtido nas reações sequenciais quando foi realizada uma reação prévia utilizando as enzimas desramificadoras (ABFs) seguida das que hidrolisam a cadeia principal (xilanase//-xilosidase) (RAHMAN et al., 2003; RAWEESRI; RIANGRUNGROJANA; PINPHANICHAKARN, 2008).

A adição de pequenas quantidades de endoxilanase, feruloil esterase e uma acetil xilana esterase aumentou significativamente (13-84\%) a hidrólise da celulose de palha de milho pela CBH I (Cel7A) de T. reesei (SELIG et al., 2008). A adição de endoxilanase em um mix de celulases comerciais melhorou significativamente a conversão de bagaço de sorgo em glicose, bem como uma redução do tempo de conversão, demonstrando ser promissor para a indústria por reduzir custos e tempo de hidrólise (PENGILLY et al., 2015) .

A utilização de enzimas termoestáveis durante o processo de hidrólise enzimática apresenta várias vantagens. As temperaturas elevadas reduzem o risco de 
contaminação por micro-organismos mesófilos além de melhorar desempenho de hidrólise devido à termoestabilidade das enzimas a altas temperaturas, além de serem mais resistentes ao $\mathrm{pH}$ e reagentes químicos em meios de reação (ARORA; BEHERA; KUMAR, 2015).

A suplementação de uma mistura contendo xilanase, $\beta$-xilosidase e acetil xilana esterase com uma arabinofuranosidase de Streptomyces sp. PC22 apresentou efeito sinérgico significativo na degradação da xilana oat spelt, SM e casca de milho com um aumento de 1,25, 1,32 e 1,21 vezes na quantidade de açúcares redutores liberados, respectivamente (RAWEESRI; RIANGRUNGROJANA; PINPHANICHAKARN, 2008).

O sinergismo entre duas $\beta$-xilosidases e um endoxilanase de $H$. insolens foi demonstrado sobre a degradação de xilana beechwood, birchwood e wheat arabinoxylan, apresentando um grau de sinergismo de 1,29 com as duas enzimas (YANG et al., 2014). Uma $\beta$-xilosidase termo-tolerante de Aspergillus sp. BCC125 produzida em $P$. pastoris KM71 demonstrou sinergia com uma xilanase, também de Aspergillus sp. BCC125, durante a hidrólise da xilana birchwood, bem como durante a sacarificação e fermentação simultâneas (SSF) in vivo com Pichia stipitis (WONGWISANSRI et al., 2013).

Misturas enzimáticas contendo uma endoxilanase, $\beta$-xilosidase e uma $\alpha$-Larabinofuranosidase recombinantes de Fusarium graminearum produzidas na bactéria E. coli foram testadas na hidrólise da xilana obtida de aveia. Os melhores resultados foram obtidos com a mistura enzimática contendo as três enzimas, promovendo um aumento de 14 a 60 vezes na concentração de xilose, quando comparado com a utilização das enzimas isoladamente, demonstrando assim a importância da utilização das misturas reacionais com diferentes atividades enzimáticas (CARAPITO et al., 2009).

A adição de uma arabinofuranosidase de Pleurotus ostreatus aumentou a hidrólise enzimática de vários substratos lignocelulósicos por coquetéis comerciais. A recuperação de xilose foi de até $56,4 \%$ quando a mistura foi suplementada com uma arabinofuranosidase (MARCOLONGO et al., 2014).

Uma endoxilanase de A. nidulans e uma $\alpha$-L-arabinofuranosidase de A. niger foram aplicadas em um coquetel de enzimas comerciais para hidrólise enzimática de palha de trigo pré-tratadas por explosão a vapor. Ambas enzimas trabalham 
sinergicamente e sua suplementação resultou em maior liberação de açúcar (ALVIRA; NEGRO; BALLESTEROS, 2011).

Para estudos de hidrólise, nem sempre são utilizadas enzimas nativas ou recombinantes purificadas. Muitas vezes, fungos ou bactérias crescidos em meio indutor secretam enzimas hidrolíticas e seu sobrenadante de cultura pode ser utilizado no processo de hidrólise enzimática. Três fungos (Trametes multicolor, Sclerotium rolfsii e Neurospora crassa) foram cultivados em diferentes substratos e a produção de várias enzimas hidrolíticas e oxidativas extracelulares envolvidas na degradação da pectina, hemicelulose e celulose foram monitoradas. Posteriormente, a capacidade dos sobrenadantes de cultura para hidrolisar polpa de beterrada pré-tratada foi avaliada. Verificou-se que a combinação de várias atividades (pectinolítica, hemicelulolítica e celulolítica) atuou sinergisticamente na hidrólise de polpa de beterraba, liberando um teor maior de açúcares redutores (KRACHER et al., 2014).

As aplicações comerciais das enzimas do complexo xilanolítico requerem enzimas que sejam capazes de trabalhar em ampla faixa de $\mathrm{pH}$, que apresentem estabilidade térmica e especificidade de substrato. Portanto, é necessário encontrar enzimas que possam hidrolisar a biomassa sob condições extremas do processamento industrial. Além disso, o grande desafio dos estudos com hidrólise de biomassa, é determinar o mínimo de enzima necessária para hidrólise máxima do substrato.

Métodos para promover a degradação da xilana presente nos materiais lignocelulósicos de forma mais eficiente são requeridos a fim de se recuperar a fração de hemicelulose, a qual é abundante na natureza e é, normalmente, desperdiçada. Visando, não somente, a produção de bioetanol, mas também os demais produtos de valor agregado que podem ser obtidos a partir desse polissacarídeo. 


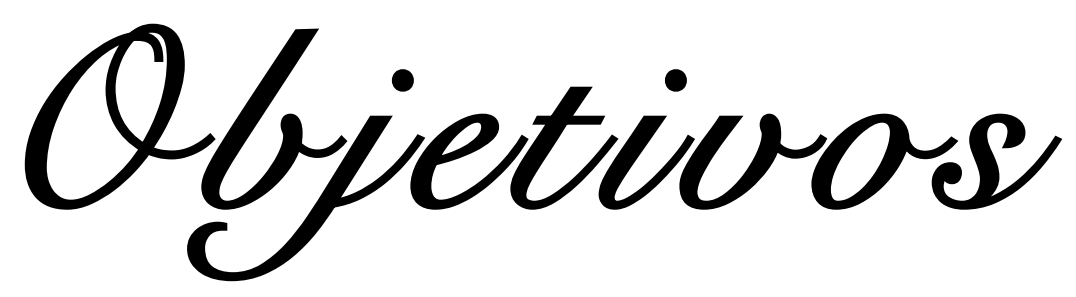




\section{OBJETIVOS}

\section{Objetivo geral:}

Realizar a produção de hemicelulases fúngicas recombinantes (endoxilanase, $\alpha$ L-arabinofuranosidase e $\beta$-xilosidase) e aplicação na hidrólise do bagaço de cana-deaçúcar.

\section{Objetivos específicos:}

- Produzir e purificar a enzima recombinante HXYN2 de H. grisea expressa em P.pastoris

- Produzir a enzima recombinate ABF3 de $P$. purpurogenum expressa em $P$. pastoris.

- Isolar o cDNA de duas $\beta$-xilosidases de H. grisea, HXYLA e HXYLB, e produzi-las em $P$. pastoris.

- Realizar a otimização da produção da enzima HXYLA por P. pastoris por meio de planejamento experimental.

- Purificar e caracterizar a enzima recombinante HXYLA

- Avaliar o sinergismo entre HXYN2, ABF3 e HXYLA na hidrólise de xilanas purificadas

- Realizar a hidrólise do BCA pré-tratado por explosão a vapor com as enzimas HXYN2, ABF3 e HXYLA.

- Avaliar o efeito da suplementação de celulases comerciais com as hemicelulases recombinantes produzidas por $P$. pastoris durante a hidrólise do BCA. 
Material e

Métodos 


\section{MATERIAL}

\section{1 - Linhagens utilizadas}

\subsection{1 - Pichia pastoris}

Foram utilizadas as linhagens da levedura P. pastoris GS115 e SMD1168 (Invitrogen) (Tabela 3). Estoques das culturas selvagem e transformadas foram acondicionados a $-80{ }^{\circ} \mathrm{C}$ em meio YPD contendo $25 \%$ de glicerol estéril.

Tabela 3 - Linhagens de $\boldsymbol{P}$. pastoris utilizadas e seus respectivos genótipos

\begin{tabular}{ccc}
\hline Linhagem & Genótipo & Fenótipo \\
\hline GS115 & his4 & His $^{-}$, Mut $^{+}$ \\
SMD1168 & Dpep4::URA3 $\Delta$ kex1: :SUC2 his4 ura3 & His $^{-}$, Mut $^{+}$
\end{tabular}

\subsection{2 - Humicola grisea}

A amostra do fungo $H$. grisea var. thermoidea utilizada no presente trabalho foi isolada de compostagem na Universidade Federal de Viçosa (MG) por Chaves (1982).

\subsection{3 - Bactérias}

As linhagens bacterianas utilizadas para manipulação de DNA foram DH5- $\alpha$ e TOP10 (Tabela 4). Tanto as células selvagens quanto as transformadas foram cultivadas em meio LB (ver seção de meios de cultura) estocadas a $-80{ }^{\circ} \mathrm{C}$ em glicerol $25 \%$ estéril.

Tabela 4 - Linhagens de $E$. coli utilizadas e seus respectivos genótipos

\begin{tabular}{|c|c|c|}
\hline Linhagem & Genótipo & Referência - fornecedor \\
\hline DH5- $\alpha$ & $\begin{array}{c}\text { end } \mathrm{A} 1 \text { recA1 hsd } \mathrm{R} 17 \text { supE44 gyrA96 thi-1 relA1 } \\
\Delta \text { lac } \mathrm{U} 169(\phi 80 \mathrm{lacZ} \Delta \mathrm{M} 15) \text { Tetr } \Delta(\mathrm{mcrA}) 183 \\
\Delta(\text { mcrCB-hsdSMR-mrr }) 173\end{array}$ & $\begin{array}{c}\text { (Sambrook e } \\
\text { Russel , 2001) }\end{array}$ \\
\hline TOP10 & 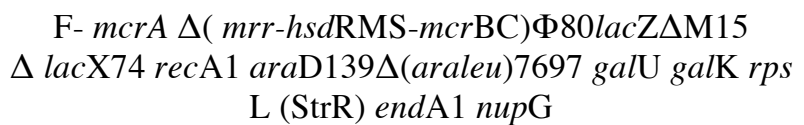 & Thermo Scientific \\
\hline
\end{tabular}

\section{3 - Vetores}

\subsection{1 - pGEM-T-Easy}

O pGEM-T-Easy é utilizado nas clonagens de fragmentos de DNA amplificados por PCR. O plasmídeo possui uma timina ligada a cada uma das extremidades 3', o que impede a recircularização do plasmídeo e melhora a eficiência de ligação de produtos de 
PCR, pois algumas polimerases termoestáveis como a Taq DNA polimerase, adicionam uma adenina nas extremidades 3' do fragmento amplificado (Promega Biotech ${ }^{\circledR}$ ). A seleção dos recombinantes é feita pela ausência da atividade de $\beta$-lactamase na presença de X-gal IPTG.

Esse vetor possui 3,0 kb e apresenta o gene de resistência a ampicilina (Amp) como marca de seleção, origem de replicação do fago F1 (ori), parte do gene lacZ que codifica o fragmento amino terminal da enzima $\beta$-lactamase, sítio múltiplo de clonagem e os promotores T7 e SP6 flanqueando a região de clonagem (Fig. 4).

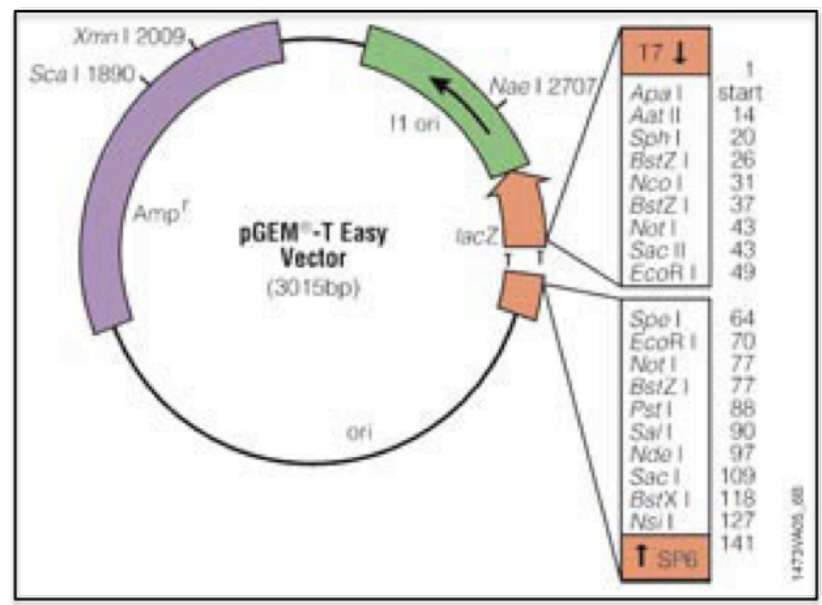

Figura 4 - Representação esquemática do mapa físico do vetor para clonagem de produto de PCR pGEM-T-Easy (Promega).

\subsection{2 - pHIL-D2 e pPIC9}

Foram utilizados os vetores de expressão para P. pastoris pHIL-D2 e pPIC9. O vetor pHIL-D2 possui 8209 nucleotídeos, apresenta o gene de resistência a ampicilina, uma origem de replicação de E. coli, a região promotora e terminadora do gene $A O X 1$ flanqueando o cassete de expressão e o gene HIS4 inativo (His-) e sequência para anelamento dos oligonucleotídeos 5' AOX1 e 3' AOX1 (Fig. 5)

O vetor pPIC9 possui $8,0 \mathrm{~kb}$, o promotor $A O X 1$ regulável por metanol, o terminador de transcrição do gene $A O X 1$ (TT), a sequência codificadora do peptídeo sinal (sinal de secreção) do gene do fator $\alpha$ de $S$. cerevisae flanqueando o sítio de policlonagem, a origem de replicação e o gene de resistência a ampicilina funcionais em E. coli, os sítios para integração no genoma de P. pastoris em HIS4 ou AOX1, numa região de múltiplos sítios de clonagem, marca de seleção auxotrófica para leveduras (HIS4) e sequência para anelamento dos oligonucleotídeos 5' AOX1 e 3' AOX1 (Fig. 5). 


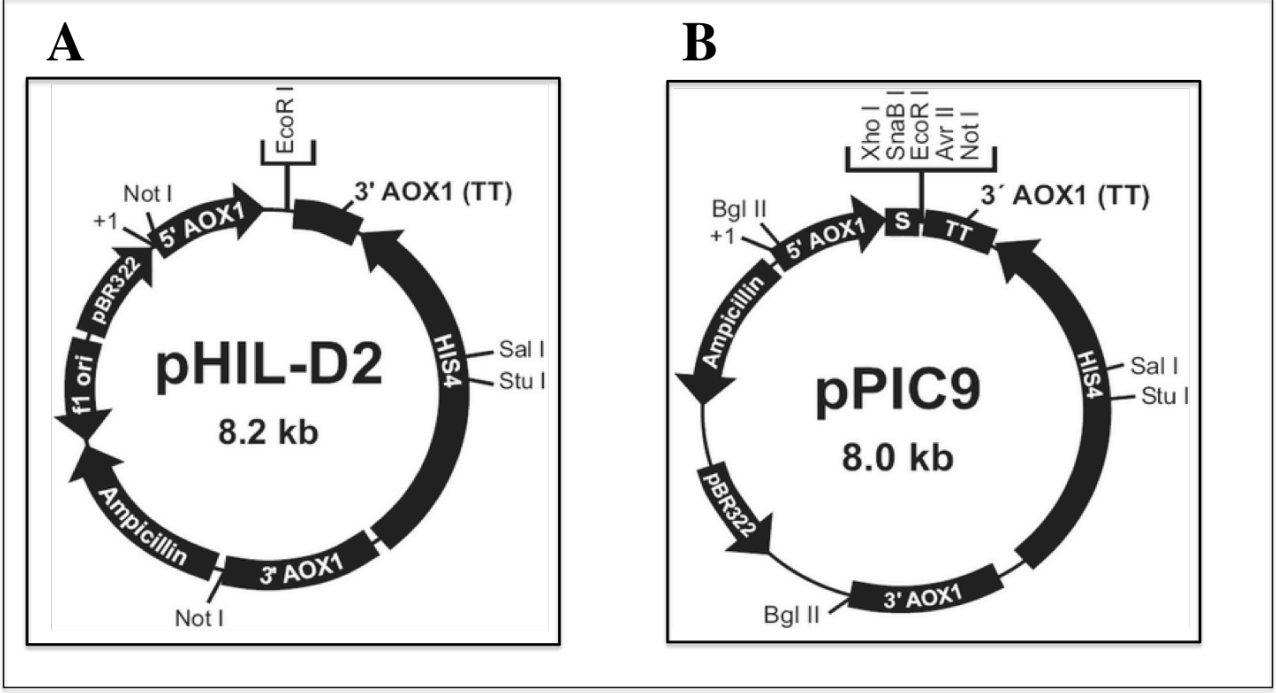

Figura 5 - Representação esquemática dos vetores de expressão para $P$. pastoris. (A) pHIL-D2 e (B) pPIC9.

\subsection{3 - pPICZA/ABF3}

$\mathrm{O}$ cDNA do gene da $\alpha$-L-arabinofuranosidase (ABF3) de $P$. purpurogenum foi cedido pelo Dr. Jaime Eyzaguirre (Facultad de Ciencias Biológicas, Universidad Andrés Bello, Santiago, Chile) e estava clonado no vetor de expressão pPICZA (Invitrogen) (Fig. 6).

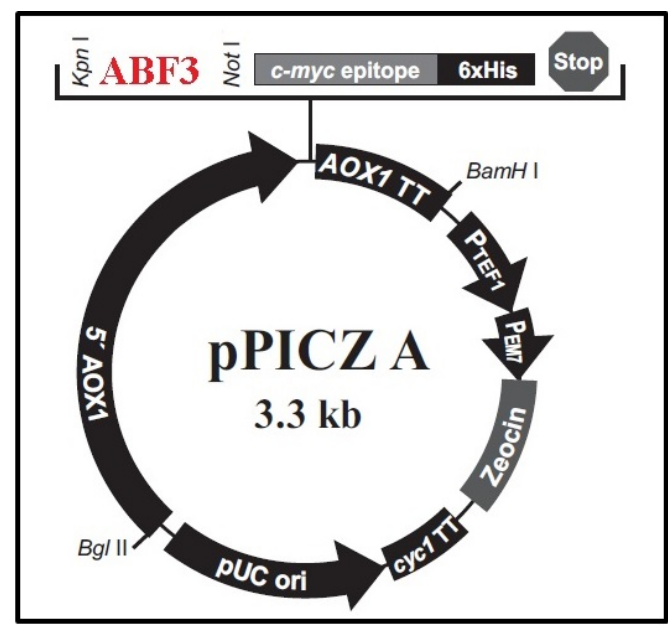

Figura 6 - Representação esquemática do mapa físico do vetor pPICZA para expressão em $P$. pastoris e sítio de clonagem para ABF3 de $P$. purpurogenum.

\section{4 - Enzimas}

- Endonucleases de restrição: EcoRI, XhoI, NotI, SacI, BglII, PmeI e Taq DNA polimerase (Thermo Scientific e Invitrogen)

- Enzima T4 DNA ligase (GIBCO®) e RNAse A (QIAGEN). 


\section{5 - Marcadores}

Marcadores de DNA: GeneRuler ${ }^{\mathrm{TM}} 1 \mathrm{~Kb}$ bp Plus DNA Ladder (Thermo Scientific número de catálogo: SM1331).

Marcadores de Proteína: Pierce ${ }^{\mathrm{TM}}$ Unstained Protein Molecular Weight Marker (14.4 kDa a 116 kDa). (Thermo Scientific - número do catálogo: 26610).

\section{6 - Kits de Uso Específico em Biologia Molecular}

Eluição do DNA do gel de agarose: Wizard® SV Gel and PCR Clean-Up System (Promega Corporation@, número de catálogo: A9381).

Extração de DNA plasmidial: Wizard® Plus SV Minipreps DNA Purification System

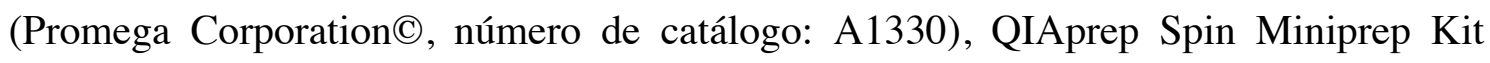
(QIAGEN, número de catálogo: 27106) e QIAGEN Plasmid Plus Midi Kit (QIAGEN, número de catálogo: 12963).

\section{7 - Meios de Cultura e soluções}

Os meios de cultura e soluções utilizados para cultivo de micro-organismos foram esterilizados em autoclave a $120^{\circ} \mathrm{C}$ por 20 minutos (SAMBROOK; RUSSELL; RUSSELL, 2006).

\subsection{1 - Meios para Cultivo de Bactérias}

\section{Meio Luria-Bertani - LB}

Peptona de caseína

Extrato de levedura

$\mathrm{NaCl}$

$\mathrm{O}$ pH foi ajustado para 7,2.

\section{Meio LB ágar}

Foi adicionado ágar bacteriológico 1,2\% (pv) ao meio LB .

\section{Meio SOB}

Bacto-Triptona

Extrato de Levedura

$20,0 \mathrm{~g} / \mathrm{L}$

$\mathrm{NaCl}$

$\mathrm{KCl}$ $5,0 \mathrm{~g} / \mathrm{L}$

$0,6 \mathrm{~g} / \mathrm{L}$

$0,5 \mathrm{~g} / \mathrm{L}$

pH ajustado para 7,2. 


\section{Meio SOC}

SOB

$100 \mathrm{~mL}$

Glicose

$20,0 \mathrm{mM}$

$\mathrm{MgCl}_{2}$

$5,0 \mathrm{mM}$

$\mathrm{MgSO}_{4}$

$5,0 \mathrm{mM}$

As soluções de glicose, $\mathrm{MgCl}_{2}$ e $\mathrm{MgSO}_{4}$ foram esterilizadas por filtração em membrana milipore $0,22 \mu \mathrm{m}$.

\subsection{2 - Meios para Cultivo da Levedura P. pastoris e Soluções Estoque}

\section{Meio YPD (Yeast Extract Peptone Dextrose)}

Extrato de Levedura

$1,0 \%(\mathrm{p} / \mathrm{v})$

Peptona de caseína $2,0 \%(\mathrm{p} / \mathrm{v})$

Glicose

$$
2,0 \%(\mathrm{p} / \mathrm{v})
$$

A glicose foi esterilizada por filtração em membrana milipore 0,22 $\mu \mathrm{m}$.

\section{Meio YPDS (Yeast Extract Peptone Dextrose Sorbitol)}
Extrato de Levedura
$1,0 \%(\mathrm{p} / \mathrm{v})$
Peptona de caseína
$2,0 \%(\mathrm{p} / \mathrm{v})$
Glicose
$2,0 \%(\mathrm{p} / \mathrm{v})$
Sorbitol
$1 \mathrm{M}(\mathrm{v} / \mathrm{v})$

A glicose foi esterilizada por filtração em membrana milipore $0,22 \mu \mathrm{m}$.

\section{Meio YPD-Ágar}

Meio YPD acrescido de ágar bacteriológico a 1,2\% (p/v).

\section{Meio de crescimento - Meio BMGY-U (Buffered Glycerol Complex Medium)}

Uréia

$$
1,34 \%(\mathrm{v} / \mathrm{v})
$$

Extrato de levedura

$1 \%(\mathrm{p} / \mathrm{v})$

Peptona

$2 \%(\mathrm{p} / \mathrm{v})$

Fosfato de potássio $\mathrm{pH} 6,0$

$$
100 \mathrm{mM}
$$

Biotina

$4 \times 10^{-5}(\mathrm{v} / \mathrm{v})$

Ampicilina

$50 \mu \mathrm{g} / \mathrm{mL}$

Glicerol

$1 \%$ 


\section{Meio de indução - Meio BMMY-U (Buffered Methanol Complex Medium)}

Uréia $1,34 \%(\mathrm{v} / \mathrm{v})$

Extrato de levedura

$1 \%(\mathrm{p} / \mathrm{v})$

Peptona

$2 \%(\mathrm{p} / \mathrm{v})$

Fosfato de potássio $\mathrm{pH} 5,0$

$100 \mathrm{mM}$

Biotina

$4 \times 10^{-5}(\mathrm{v} / \mathrm{v})$

Ampicilina

$50 \mu \mathrm{g} / \mathrm{mL}$

Metanol

$1 \%$

Para preparo dos meios BMGY-U e BMMY-U, uma solução contendo extrato de levedura, peptona e uréia foi autoclavada separadamente e depois foram adicionados os demais reagentes previamente esterilizados por filtração (Biotina, Metanol, Ampicilina e glicerol) ou por autoclavagem (Tampão Fosfato de Potássio), adicionando água estéril para completar o volume.

\section{Meio MD (Minimal Dextrose)}

YNB

Dextrose

Biotina

Ágar bacteriológico

$$
1,34 \%(\mathrm{p} / \mathrm{v})
$$$$
2 \%(\mathrm{p} / \mathrm{v})
$$$$
4 \times 10^{-5}(\mathrm{v} / \mathrm{v})
$$$$
1,4 \%(\mathrm{p} / \mathrm{v})
$$

YNB (Yeast Nitrogen Base) - Solução estoque de 10X

YNB* (Yeast Nitrogen Base Without Amino acids) (Difco)

$3,4 \%(\mathrm{p} / \mathrm{v})$

Sulfato de amônio $\left(\mathrm{NH}_{4} \mathrm{SO}_{4}\right)$ $10 \%(\mathrm{p} / \mathrm{v})$

Esterelizada por filtração em membrana microbiológica com poros de $0,22 \mu \mathrm{m}$ (Millipore $\left.^{\mathrm{TM}}\right)$ e estocada a $4^{\circ} \mathrm{C} . *(\mathrm{~s} /$ aminoácidos e s/ sulfato de amônio).

\section{Tampão Fosfato de Potássio 1 M, pH 6,0}

$\begin{array}{ll}\mathrm{K}_{2} \mathrm{HPO}_{4} & 132 \mathrm{mM} \\ \mathrm{KH}_{2} \mathrm{PO}_{4} & 686 \mathrm{mM}\end{array}$

Esterilizada em autoclave por 20 minutos e estocada a temperatura ambiente.

\section{Biotina - Solução estoque 500X}

Biotina

$$
0,02 \%(\mathrm{p} / \mathrm{v})
$$

Esterelizada por filtração em membrana microbiológica com poros de $0,22 \mu \mathrm{m}$ (Millipore $^{\mathrm{TM}}$ ) e estocada a $4{ }^{\circ} \mathrm{C}$. 
Glicerol - Solução estoque

Glicerol

$50 \%(\mathrm{v} / \mathrm{v})$

\section{Sorbitol 1 M}

Sorbitol

$18,21 \mathrm{~g}$

Água destilada (q.s.p)

$100 \mathrm{~mL}$

\subsection{3 - Meios para Cultivo do Fungo H. grisea}

Meio Ágar Aveia - AA

Farinha de aveia infantil (Quaker) 4,0\% (p/v)

Ágar $1,5 \%(\mathrm{p} / \mathrm{v})$

Água destilada (q.s.p) $100 \mathrm{~mL}$

Meio Mínimo - MM (Pontecorvo et al., 1953)

$\begin{array}{ll}\mathrm{NaNO} 3 & 0,6 \%(\mathrm{p} / \mathrm{v}) \\ \mathrm{KCl} & 0,05 \%(\mathrm{p} / \mathrm{v}) \\ \mathrm{KH} 2 \mathrm{PO} 4 & 0,15 \%(\mathrm{p} / \mathrm{v}) \\ \mathrm{ZnSO} 4 & 0,001 \%(\mathrm{p} / \mathrm{v}) \\ \mathrm{FeSO} 4 & 0,001 \%(\mathrm{p} / \mathrm{v})\end{array}$

Aferir o $\mathrm{pH}$ para 6,8 e adicionar:

(NH4)2SO4

$0,25 \%(\mathrm{p} / \mathrm{v})$

Extrato de Levedura

$0,25 \%(\mathrm{p} / \mathrm{v})$

\section{8 - Antibióticos}

- Ampicilina (100 $\mu \mathrm{g} / \mathrm{mL}$ para E. coli) (Sigma Aldrich) - $100 \mathrm{mg} / \mathrm{mL}$. Esterilizada por filtração.

- Zeocina $(25 \mu \mathrm{g} / \mathrm{mL}$ para E. coli e $100 \mu \mathrm{g} / \mathrm{mL}$ para P. pastoris) (Invitrogen) $100 \mathrm{mg} / \mathrm{mL}$.

\section{9 - Determinação da Atividade Celulolítica e Xilanolítica}

Tampão citrato de sódio $50 \mathrm{mM}$ - pH 4,8

Ácido cítrico $0,1 \mathrm{M}$

$23 \mathrm{~mL}$

Solução de citrato de sódio $0,1 \mathrm{M}$

$27 \mathrm{~mL}$

Água destilada

$50 \mathrm{~mL}$ 


\section{Solução de Carboximetilcelulose CMC 4\%}

Carboximetilcelulose (CMC low viscosity - Sigma) $4 \mathrm{~g}(\mathrm{p} / \mathrm{v})$

Tampão citrato de sódio 50 mM, pH 4,8 (q.s.p) $100 \mathrm{~mL}$

A solução foi dissolvida em micro-ondas até a solubilização complete do soluto.

\section{Solução de Xilana $1 \%$}

Xilana Oat Spelt ou Xilana Beechwood (Sigma) $1 \mathrm{~g}(\mathrm{p} / \mathrm{v})$

Tampão citrato de sódio 50 mM, pH 4,8 (q.s.p) 100 mL

A xilana Oat Spelt foi dissolvida em tampão citrato de sódio 0,05 M pH4,8 após aquecimento em micro-ondas por $1 \mathrm{~min}$, agitação manual, repouso por $1 \mathrm{~min}$. Esse procedimento foi repetido 3 vezes. Em seguida foi estocado a $-20^{\circ} \mathrm{C}$. A xilana beechwood também foi dissolvida em tampão citrato de sódio 0,05 $\mathrm{M} \mathrm{pH4,8} \mathrm{e,}$ posteriomente, submetida a agitação constante por 10 min até a completa solubilização.

\section{DNS (ácido dinitrosalicílico)}

Ácido 3,5-dinitrosalicílico

$0,75 \%$

$\mathrm{NaOH}$

$1,4 \%$

Tartarato de sódio e potássio

Fenol

$0,54 \%$

Metabissulfito de sódio

$0,58 \%$

Água destilada (q.s.p.)

Inicialmente, o DNS e o $\mathrm{NaOH}$ foram dissolvidos em água destilada. Posteriormente adicionou-se o tartarato de sódio e potássio, fenol e o metabissulfito de sódio. A solução foi deixada sob agitação até ser observada a completa dissolução dos reagentes quando o volume de água foi completado para $1000 \mathrm{~mL}$. A solução final foi titulada com HCL 0,1 M, utilizando fenolftaleína como indicador (MILLER, 1959).

\subsection{0 - Soluções para eletroforese em gel de agarose}

Solução de brometo de etídeo $1 \%(p / v)$

Brometo de etídeo $1,0 \mathrm{~g}$

Água destilada $100 \mathrm{~mL}$ 
Tampão de corrida para eletroforese em gel de agarose - TEB (10X)

Triz base

Ácido bórico

EDTA
$0,89 \mathrm{M}$

$0,89 \mathrm{M}$

$0,08 \mathrm{M}$

Tampão de amostra para DNA (10X)

TEB (20X)

Glicerol

Azul de bromofenol

Xilenocianol

$$
\begin{aligned}
& 50 \%(\mathrm{v} / \mathrm{v}) \\
& 30 \%(\mathrm{v} / \mathrm{v}) \\
& 0,25 \%(\mathrm{p} / \mathrm{v}) \\
& 0,25 \%(\mathrm{p} / \mathrm{v})
\end{aligned}
$$

\subsection{1 - Soluções para extração de DNA total}

Tampão TE (10X)

Tris- $\mathrm{HCl} \mathrm{pH} 8,0$

EDTA pH 8,0

$0,1 \mathrm{M}$

Tampão STE pH 8.0

Tris $\mathrm{HCl}(\mathrm{pH} 8,0)$

$0,2 \mathrm{M}$

EDTA $(\mathrm{pH} 8,0)$

$0,01 \mathrm{M}$

$\mathrm{NaCl}$

$0,5 \mathrm{M}$

SDS

$0,1 \%$

4.12 - Soluções para análise de proteínas em gel de Poliacrilamida Desnaturante (SDS-PAGE) (LAEMMLI, 1970).

\section{Ácido tricloroacético (TCA)}

Um volume de $1 \mathrm{~mL}$ de água destilada foi adicionado a $50 \mathrm{~g}$ de ácido tricloroacético. Após todo o ácido ser dissolvido, adicionou-se água destilada suficiente para um volume final de $50 \mathrm{~mL}$ e a solução obtida foi estocada a $4{ }^{\circ} \mathrm{C}$.

Persulfato de amônio (P.A.) $10 \%$ (P/V)
P.A.
$1 \mathrm{~g}$
Água destilada (q.s.p.)
$10 \mathrm{~mL}$ 
Dodecil sulfato de sódio (SDS) - $20 \%$

SDS

$20,0 \mathrm{~g}$

Água destilada

$100 \mathrm{~mL}$

Tampão de amostra para proteína (2x)

Tris-HCl 1 M pH 6,8

$200 \mathrm{mM}$

SDS

$4,0 \%(\mathrm{p} / \mathrm{v})$

$\beta$-Mercaptoetanol

$4,0 \%(\mathrm{v} / \mathrm{v})$

Glicerol

$20,0 \%(\mathrm{v} / \mathrm{v})$

Azul de bromofenol

$0,1 \%(\mathrm{p} / \mathrm{v})$

Acrilamida: Bis-acrilamida (39:1)

Acrilamida $39 \%(\mathrm{p} / \mathrm{v})$

Bis-acrilamida

$1 \%(\mathrm{p} / \mathrm{v})$

A solução foi filtrada em papel de filtro e estocada ao abrigo da luz a $4{ }^{\circ} \mathrm{C}$.

Tampão de corrida - Tris-glicina 5X (estoque)

Trizma Base

$15,1 \mathrm{~g}$

Glicina

$72,0 \mathrm{~g}$

SDS

$5,0 \mathrm{~g}$

Água destilada (q.s.p) $1 \mathrm{~L}$

Tris-HCI 1,5 M - pH 6,8

Trizma Base

$12,1 \mathrm{~g}$

Água destilada (q.s.p)

$100 \mathrm{~mL}$

$\mathrm{O} \mathrm{pH}$ foi ajustado com $\mathrm{HCl}$ fumegante.

\section{Tris-HCl 1 M - pH 8,8}

Trizma Base

$18,2 \mathrm{~g}$

Àgua destilada

$100 \mathrm{~mL}$

$\mathrm{O} \mathrm{pH}$ foi ajustado com $\mathrm{HCl}$ fumegante.

\section{Preparo dos géis}

Os géis foram preparados conforme descrito na tabela a seguir: 
Tabela 5 - Preparação de gel para SDS-PAGE.

\begin{tabular}{lcc}
\hline Soluções & Concentrador $\mathbf{4 \%}$ & Separador 13\% \\
\hline Acrilamida:Bis-acrilamida (39:1) & $500 \mu \mathrm{L}$ & $4,1 \mathrm{~mL}$ \\
Tampão Tris-HCl pH 8,8 & - & $3,1 \mathrm{~mL}$ \\
Tampão Tris-HCl pH 6,8 & $630 \mu \mathrm{L}$ & - \\
Água destilada & $3,80 \mathrm{~mL}$ & $5,150 \mathrm{~mL}$ \\
SDS 10 \% & $50 \mu \mathrm{L}$ & $125 \mu \mathrm{L}$ \\
Persulfato de amônia 10 \% & $50 \mu \mathrm{L}$ & $125 \mu \mathrm{L}$ \\
TEMED & $5 \mu \mathrm{L}$ & $5 \mu \mathrm{L}$
\end{tabular}

Revelação das proteínas por coloração do gel com Azul de Comassie

Solução corante

Comassie blue R-250

$0,2 \%(\mathrm{p} / \mathrm{v})$

Etanol

$40 \%(\mathrm{v} / \mathrm{v})$

Ácido Acético Glacial

$10 \%(\mathrm{v} / \mathrm{v})$

Água destilada (q.s.p.)

$1000 \mathrm{~mL}$

\section{Solução descorante para gel corado com Azul de Comassie}

Metanol $(99,8 \%)$

$30 \mathrm{~mL}$

Ácido Acético Glacial $(99,7 \%)$

$7 \mathrm{~mL}$

Água destilada (q.s.p)

$100 \mathrm{~mL}$

\subsection{3 - Substratos empregados como fonte de carbono}

Foram utilizados os seguintes substratos: Bagaço de cana-de-açúcar lavado e moído (BCA), Carboximetilcelulose - celulose microcristalina (CMC, SigmaAldrich(C), Farelo de sabugo de milho lavado e moído (SM), Farelo de trigo lavado e moído (FT), Farinha de aveia (FA - QUAKER ®), Farelo de palha de arroz lavada e moída (PA), Xilana beechwood (Sigma-Aldrich), Celulose semi- cristalina Avicel (Sigmacell - Sigma-Aldrich ${ }^{\circledR}$ ).

O BCA, FT, SM e PA foram preparados para sua utilização, sendo submerso em água por $24 \mathrm{~min}$, lavado em água corrente destilada por pelo menos 5 vezes ou até a água não liberar mais açúcares redutores, mensurado pelo método do DNS (MILLER, 
1959), e em seguida seco a temperatura ambiente por 24 h. Foram moídos em moinho utilizando-se uma peneira de 20 mesh.

\subsection{4 - Preparo da medula da cana-de-açúcar}

O preparo da medula da cana-de-açúcar foi realizado de acordo com COSTA e colaboradores (2013), com modificações. Inicialmente foi retirada a região da epiderme (cerca de $2 \mathrm{~mm}$ ) e a região dos nós do caule da cana-de-açúcar, utilizando apenas a região dos internós, as amostras foram moídas para remoção do caldo e segmentados em pedaços de 2,5 cm. Em seguida, as amostras de medula passaram por ciclos de lavagens em água destilada $\left(1 \mathrm{~h}, 30^{\circ} \mathrm{C}, 120 \mathrm{rpm}\right)$ até a eliminação da glicose. Após as lavagens, a amostra (fração insolúvel) foi homogeneizada em solução de ácido abscórbico $(5 \mathrm{~g} / \mathrm{L})$ por $1 \mathrm{~h}, 30{ }^{\circ} \mathrm{C}, 120 \mathrm{rpm}$, filtrada e seca a temperatura ambiente. Por fim, a amostra foi triturada em moinho de facas equipado com uma peneira de 20 mesh e estocada a $4{ }^{\circ} \mathrm{C}$. 


\section{MÉTODOS}

\section{1 - Cultivo e manutenção de micro-organismos}

As bactérias foram cultivadas a temperatura de $37^{\circ} \mathrm{C}$ em meio LB. As linhagens SMD1168 e GS115 da levedura P pastoris foram cultivadas em meio YPD ágar a 28 ${ }^{\circ} \mathrm{C}$ por 3 dias e estocadas a $4{ }^{\circ} \mathrm{C}$. O fungo $H$. grisea foi cultivado em meio Ágar Aveia (AA). Para a produção de esporos, o fungo foi semeado em meio AA, incubado por 3 dias a $42{ }^{\circ} \mathrm{C}$ e deixado à temperatura ambiente por mais 3 dias para a completa esporulação.

\section{2- Produção de $\alpha$-L-arabinofuranosidase e $\beta$-xilosidases por $H$. grisea}

Para a análise da produção das enzimas $\alpha$-L-arabinofuranosidase e $\beta$-xilosidases pelo fungo $H$. grisea, os esporos foram coletados em solução de $\mathrm{NaCl} 0,15 \mathrm{M}$ e quantificados em câmara de Newbauer. Uma suspensão de 3,5.107 esporos $/ \mathrm{mL}$ foram inoculados em $100 \mathrm{~mL}$ de meio mínimo (MM) contidos em frascos erlenmeyer de 250 mL. O fungo foi cultivado por fermentação submersa em MM contendo substratos utilizados como fonte de carbono: 1, 2 e 3\% de Bagaço de cana-de-açúcar (BCA), $1 \%$ sabugo de milho (SM), $1 \%$ de palha de arroz (PA), $1 \%$ de farinha de aveia (FA), $1 \%$ de xilana beechwood, 0,5\% de avicel (Sigma), 0,5\% de carboximetilcelulose (CMC) e 1, 2 e $3 \%$ de farelo de trigo (FT). O cultivo foi realizado a $42{ }^{\circ} \mathrm{C}$, sob agitação de $120 \mathrm{rpm}$. A cada 24 horas foram retiradas alíquotas de $1 \mathrm{~mL}$ e as amostras foram submetidas a centrifugação de $10.000 \mathrm{rpm}$ por 10 min e o sobrenadante coletado e analisado quanto à atividade enzimática conforme o item 6.4.

\section{3 - Dosagem da atividade xilanolítica pelo Método de DNS}

O ensaio foi realizado seguinto o método do DNS, descrito por (MILLER, 1959). Os ensaios foram realizados em microplaca de 96 poços. Para a reação, foram adicionados $10 \mu \mathrm{l}$ da amostra em $90 \mu \mathrm{l}$ do substrato (xilana oat spelt ou a xilana beechwood $1 \%$ ) seguindo-se a incubação a $50{ }^{\circ} \mathrm{C}$ por $5 \mathrm{~min}$. Em seguida, foi adicionado $150 \mu \mathrm{l}$ de DNS e a reação foi fervida por 5 min e mantida no gelo por mais 5 min. Posteriormente, foi feita a leitura no espectrofotometro a $550 \mathrm{~nm}$ no A leitura foi realizada por leitor automático de microplacas modelo ELx800 com 96 poços (Biotek, Winooski, EUA), por meio do programa GEN 5. 


\section{4 - Dosagem da atividade de Arabinofuranosidase e $\beta$-xilosidase}

As atividades de $\alpha$-L-arabinofuranosidase e $\beta$-xilosidase foram determinadas utilizando como substrato $\rho$-nitrofenil-L-arabinopiranosídio (pNPA, Sigma N3641) e o $\rho$-nitrofenil-D-xilopiranosídeo (pNPX, Sigma N2132), respectivamente, na concentração de $5 \mathrm{mM}$. Os ensaios foram realizados em tampão citrato de sódio $50 \mathrm{mM}$ pH 4,8. A mistura de reação, contendo $10 \mu \mathrm{L}$ de sobrenadante de cultura, $100 \mu \mathrm{L}$ de tampão e $40 \mu \mathrm{L}$ de uma solução $5 \mathrm{mmol} / \mathrm{L}$ de pNPA ou pNPX, foi incubada por 5 min a $40{ }^{\circ} \mathrm{C}$, a reação foi encerrada pelo resfriamento em banho de gelo e pela adição de 100 $\mu \mathrm{L}$ de uma solução de $\mathrm{Na}_{2} \mathrm{CO}_{3} 0,5 \mathrm{M}$, interrompendo a reação por deslocar o $\mathrm{pH}$ para o meio básico, onde as enzimas não apresentam mais atividade e por ser o $\mathrm{pH}$ onde o $p$ nitrofenol exibe coloração amarela.

Uma unidade (U) de atividade foi definida como a quantidade de enzima capaz de liberar 1 umol de 4-nitrophenol/min, medida pela absorbância a $405 \mathrm{~nm}$. A quantidade de $\rho$-nitrofenol (pNP) liberada foi determinada por leitura realizada por leitor automático de microplacas modelo ELx800 com 96 poços (Biotek, Winooski, EUA), por meio do programa GEN 5.

\section{5 - Dosagem de proteínas totais}

A concentração de proteínas foi determinada pelo método descrito por Bradford (1976), utilizando albumina de soro bovino (BSA-Sigma) como padrão. Um volume de $10 \mu \mathrm{L}$ da amostra de sobrenadante da cultura foi adicionado a $190 \mathrm{~mL}$ do reagente de Bradford. Após incubação por 15 minutos à temperatura ambiente e ao abrigo da luz, realizou-se a leitura de absorbância das amostras à $595 \mathrm{~nm}$.

\section{6 - Extração de DNA total de $H$.grisea}

Para extração de DNA total de $H$. grisea, o fungo foi cultivado em MM contendo BCA $2 \%$. O micélio foi coletado após 120 h de cultivo e em um microtubo de $2 \mu \mathrm{L}$ foram adicionados $100 \mu \mathrm{L}$ de tampão STE, $1 \mu \mathrm{L}$ de RNAse A (10 mg/mL), aproximadante $50 \mu \mathrm{L}$ de acid-washed glass beads (Sigma), $40 \mu \mathrm{L}$ de TE pH 8,0, 120 $\mu \mathrm{L}$ de fenol: clorofórmio (1:1) e em seguida essa mistura foi para o vortex por $1 \mathrm{~min}$. Posteriormente, procedeu-se a centrifugação a $12000 \mathrm{rpm}$ por 5 min à temperatura ambiente. A fase aquosa foi transferida para um novo microtubo onde foi adicionado 3 volumes de etanol absoluto e $10 \%$ do volume de acetato de sódio $(3 \mathrm{M}, \mathrm{pH} 5,2)$ e em 
seguida foi realizada a centrifugação a $12000 \mathrm{rpm}, 4^{\circ} \mathrm{C}$. O sobrenadante foi removido e o pellet foi lavado com etanol $70 \%$ gelado. Foi realizada nova centrifugação por 5 min a $12000 \mathrm{rpm}$ e o sobrenadante foi removido e o pellet secado a temperatura ambiente. Ao final do procedimento, o pellet foi ressuspendido em $50 \mu \mathrm{L}$ de TE.

\section{7 - Extração de RNA total de $H$. grisea}

Para a extração de RNA, o fungo $H$. grisea foi cultivado em MM contendo FT 2\% e BCA 2\% e amostras de micélio foram coletados após 12, 24, 36 (FT 2\%) e 144, 168 e 192 horas (BCA 2\%) de cultivo e utilizados para a extração de RNA com TRIzol®. A massa de micélio foi congelada em cadinho com $\mathrm{N}_{2}$ líquido, macerada até adquirir aspecto de pó e transferido para um tubo cônico de $50 \mathrm{~mL}$ contendo $1 \mathrm{~mL}$ de TRIzol ${ }^{\circledR}$ para cada $3 \mathrm{~g}$ de macerado e pérolas de vidro suficiente para cobrir o fundo do tubo. Em seguida, a mistura foi agitada em vortex durante 5 minutos e centrifugada a $2000 \times \mathrm{x} g$ por $10 \mathrm{~min}$. O sobrenadante foi transferido para um microtubo contendo 0,2 $\mathrm{mL}$ de clorofórmio por $\mathrm{mL}$ de TRIzol ${ }^{\circledR}$ inicial. A mistura no tubo foi homogeneizada e incubada por 3 minutos a temperatura ambiente antes de ser centrifugada a $12000 \mathrm{x} g$ por 15 min a $4{ }^{\circ} \mathrm{C}$. A fase aquosa foi transferida para um novo tubo de microcentrífuga adicionado de $0,5 \mathrm{~mL}$ de isopropanol por $\mathrm{mL}$ de TRIzol ${ }^{\circledR}$, misturada por inversão e incubada a temperatura ambiente por 10 minutos seguida de centrifugação nas mesmas condições anteriores. O sobrenadante foi descartado e o precipitado foi lavado com 1 $\mathrm{mL}$ de etanol $75 \%$ por $\mathrm{mL}$ de TRIzol ${ }^{\circledR}$ utilizado. A mistura foi homogeneizada em vortex e centrifugada a 7500 x $g$ por 5 min a $4{ }^{\circ} \mathrm{C}$. O sobrenadante foi novamente descartado, o precipitado contendo o RNA foi secado por 5 a 10 minutos e ressuspendido em $50 \mu \mathrm{L}$ de água MiliQ (RNAse free). O RNA total extraído, da indução em FT 2\% e BCA 2\%, foram aplicados em uma coluna contendo uma matriz de oligodT (Oligotex ${ }^{\circledR}$ Quiagen) que foi utilizada para purificação dos RNAs mensageiros e formação de uma mistura de RNAs. A purificação foi realizada conforme instruções do fabricante.

\section{8 - Eletroforese de ácidos nucléicos em gel de agarose}

A eletroforese em gel de agarose foi utilizada para análise e avaliação da qualidade, quantificação do DNA e análise de fragmentos de DNA. A agarose foi preparada em concentrações de 0,8 (p/v) em tampão de corrida TAE 1X e contendo 0,5 
$\mu \mathrm{g} / \mathrm{mL}$ de brometo de etídeo. As amostras eram aplicadas no gel e submetidas à eletroforese, como descrito por (SAMBROOK; RUSSEL, [s.d.]) Para visualização e fotodocumentação do DNA utilizou-se a incidência de luz ultravioleta em transiluminador Gel Doc ${ }^{\mathrm{TM}}$ EZ (BioRad).

\section{9 - Extração de DNA plasmidial}

As extrações de DNA plasmidial foram realizadas utilizando os kits Wizard® Plus SV Minipreps DNA Purification System ou QIAprep Spin Miniprep Kit para extrações em pequena escala e o QIAGEN Plasmid Plus Midi Kit para extrações em média escala. Os procedimentos foram realizados conforme instrução do fabricante.

\subsection{0 - Precipitação de DNA}

Para precipitação de DNA foram adicionados 1/10 do volume total de acetato de sódio $3 \mathrm{M}$ e 2,5 volumes de etanol $100 \%$ gelado, procedendo-se a incubação a $-20{ }^{\circ} \mathrm{C}$ por $30 \mathrm{~min}$ durante à noite. Posteriormente, as amostras foram submetidas à centrifugação a $12000 \mathrm{rpm}$, por $40 \mathrm{~min}$ a $4{ }^{\circ} \mathrm{C}$. O sobrenadante foi descartado e, em seguida, adicionou-se $1 \mathrm{~mL}$ de etanol $70 \%$ gelado para lavar o precipitado. Foi feita nova centrifugação a $12000 \mathrm{rpm}_{\text {s }}$ por $20 \mathrm{~min}$, sendo o sobrenadante novamente descartado. O precipitado foi seco a temperatura ambiente, ressuspendido no volume desejado em água MilliQ contendo RNAse e estocado no freezer a $-20{ }^{\circ} \mathrm{C}$.

\subsection{1 - Purificação de DNA em gel de agarose}

Os fragmentos de DNA foram excisados do gel de agarose $0,8 \%$ e purificados utilizando-se o kit Wizard® SV Gel and PCR Clean-Up System (Promega), conforme as especificações do fabricante.

\subsection{2 - Preparação de células bacterianas eletrocompetentes}

As células de E. coli da linhagem desejada foram crescidas em $10 \mathrm{~mL}$ de meio SOC em erlenmeyer de $125 \mathrm{~mL}$ e incubadas a $37{ }^{\circ} \mathrm{C}$ durante a noite e sob agitação a $200 \mathrm{rpm}$. Em seguida, $5 \mathrm{~mL}$ do pré-inóculo foram adicionados a $500 \mathrm{~mL}$ de meio SOC em erlenmeyer de $1 \mathrm{~L}$ e essa cultura foi incubada a $37{ }^{\circ} \mathrm{C}$ sob agitação (200 rpm) até atingir uma $\mathrm{OD}_{600}$ de 0,35 a 0,4 . As células foram resfriadas em gelo e em seguida coletadas por centrifugação a $3000 \mathrm{rpm}$ por $20 \mathrm{~min}$ a $4{ }^{\circ} \mathrm{C}$. Em seguida, as células foram ressuspensas em água ultrapura estéril gelada e centrifugada. Esse procedimento foi 
realizado por 2 vezes. Após isso, as células foram lavadas com glicerol $10 \%$ e centrifugadas $3000 \mathrm{rpm}$ por $20 \mathrm{~min}$ a $4{ }^{\circ} \mathrm{C}$. Posteriormente, ressuspendeu-se cuidadosamente as células em $2 \mathrm{~mL}$ de glicerol 10\%. Finalmente, as células foram aliquotadas em tubos eppendorf (40 a $80 \mu \mathrm{L}$ por tubo) e estocadas a $-80{ }^{\circ} \mathrm{C}$.

\subsection{3 - Transformação de $E$. coli por eletroporação}

Uma alíquota de célula competente previamente preparada foi utilizada para cada sistema de ligação. Foram adicionados de 1 a $5 \mu \mathrm{L}$ do sistema de ligação às células. Após este período, as células foram colocadas em uma cubeta de $0,1 \mathrm{~cm}$ (Biorad) previamente gelada e submetidas a eletroporação conforme instrução do fabricante (Gene Pulser Xcell - Biorad). Posteriormente, foram adicionados $1000 \mu \mathrm{L}$ de meio LB ao sistema e incubado por 1 hora a $37{ }^{\circ} \mathrm{C}$ sob agitação a $200 \mathrm{rpm}$. Em seguida as células foram centrifugadas por $10 \mathrm{~min}$ a $3500 \mathrm{rpm}$ e ressuspensas no volume desejado em placas contendo LB ágar com antibiótico. As placas foram incubadas a 37 ${ }^{\circ} \mathrm{C}$ durante a noite.

\subsection{4 - Desenho dos oligonucleotídeos para amplificação dos genes de $\alpha$-L- arabinofuranosidase e $\beta$-xilosidase de $H$. grisea}

Para tentativa de amplificação de genes de $\alpha$-L-arabinofuranosidase de $H$. grisea foram desenhados os oligonucleotídeos degenerados que foram obtidos com base na sequência de proteína de duas arabinofuranosidases de $H$. insolens (Sørensen et al., 2006). A sequencia dos oligonucleotídeos está apresentada na Tabela 6.

Tabela 6 - Lista de oligonucleotídeos utilizados para ABF de H. grisea

\begin{tabular}{cccc}
\hline Nome & Seqüência $\left(\mathbf{5}^{\prime}-\mathbf{3}\right.$ ') & Bases & Tm \\
\hline GH43-S & ATGCTCGGCCTCAAGGTCCTCTGCCTCTCS & 30 & 74,2 \\
GH43-AT & GATCATGTTCATCTTGAAGCCCTTGACC & 28 & 66,1 \\
GH51-S & ATGAAGTTCGTCTCSTCSCTCCTCGTCGCC & 30 & 72,8 \\
GH51-AT & GACGCGGAGCTCGAGGACGTTGACSGACCA & 30 & 75,6 \\
\hline
\end{tabular}

Para tentativa de amplificação de genes de $\beta$-xilosidase de $H$. grisea foram desenhados os oligonucleotídeos com base na sequência de nucleotídeos de duas $\beta$ xilosidases (GenBank: KC962400.1 e GenBank: KC962401.1) de H. insolens (Yang et. al, 2014). A sequência dos oligonucleotídeos está apresentada na Tabela 7. 
Tabela 7 - Lista de oligonucleotídeos utilizados para primeira tentativa de amplificação de genes de $\beta$-xilosidase de $H$.grisea

\begin{tabular}{ccccc}
\hline Nome & Seqüência (5'-3') & Bases & Tm & Amplicom \\
\hline AF & ATGGCGCCCCTCATCACCAA & 20 & 64,5 & 984 \\
AR & TTACTCAGGCTTCTCCGTCACGAT & 24 & 64,6 & 984 \\
BF & ATGCCCCAAGTCCGTAACCCT & 21 & 65,5 & 1617 \\
BR & TCAAATCTCATAGCGATCGCTCG & 23 & 62,8 & 1617 \\
\hline
\end{tabular}

Para a análise da integração do cassete de expressão no genoma da levedura $P$. pastoris foi utilizado os oligonucleotídeos AOX5 e AOX3 que se anelam no promotor e no terminador do gene AOX1 e que está presente nos vetores de expressão pHILD2 e pPIC9. Além disso, para realização da ligação nos vetores de expressão foram utilizados oligonucleotídeos contendo sítios de restrição (Tabela 8).

Tabela 8 - Demais oligonucleotídeos utilizados. Em negrito os sítios de restrição e sublinhado a sequência Histag.

\begin{tabular}{ccccc}
\hline Nome & Seqüência (5'-3') & Bases & Tm & Sítio \\
\hline AOX5 & GACTGGTTCCAATTGACAAGC & 21 & 74,2 & \\
AOX3 & GCAAATGGCATTCTGACATCC & 21 & 66,1 & \\
AFEco & GAATTCATGGCGCCCCTCATCACCAA & 26 & 67,7 & EcoRI \\
ARNot & GCGGCCGCTTACTCAGGCTTCTCCGTCAC & 29 & 74,5 & NotI \\
BFEco & GAATTCATGCCCCAAGTCCGTAACCCT & 27 & 67,6 & EcoRI \\
BRNot & GCGGCCGCTCAAATCTCATAGCGATCGC & 28 & 71,9 & NotI \\
ARHNot & GCGGCCGCTTAATGATGATGATGATGATGCT & 26 & 66,3 & NotI \\
& CAGGCTTCTCCGTCAC & & & \\
BRHNot & GCGGCCGCTCAATGATGATGATGATGATGA & 29 & 76,1 & NotI \\
& ATCTCATAGCGATCGC & & & \\
\hline
\end{tabular}

\subsection{5 - Obtenção da primeira fita de cDNA}

Para síntese da primeira fita do cDNA, foi utilizado o RNA total e o kit "First Strand cDNA Synthesis Kit” (Thermo Scientific ${ }^{\circledR}$ ), seguindo as recomendações do fabricante. Na reação de síntese foram utilizados aproximadamente $5 \mu \mathrm{g}$ de RNA total, previamente tratado com DNAse, e $1 \mu \mathrm{L}$ do "primer" oligo(dT) âncora $(10 \mu \mathrm{M})$ que foram incubados a $65{ }^{\circ} \mathrm{C}$ por $5 \mathrm{~min}$. Após esse período, a reção foi transferida para o gelo e foram adicionados $4 \mu \mathrm{L}$ do tampão de reação $5 \mathrm{x}, 1 \mu \mathrm{L}$ do inibidor de RNase (20 $\mathrm{U} / \mu \mathrm{L}), 2 \mu \mathrm{L}$ mix dNTP $(10 \mathrm{mM}), 1 \mu \mathrm{L}$ transcriptase reversa RevertAid M-MuLV (200 $\mathrm{U} / \mu \mathrm{L})$ e água deionizada para um volume final de $21 \mu \mathrm{L}$. A reação se processou por 60 
min a $37{ }^{\circ} \mathrm{C}$, e foi encerada aquecendo o tubo a $70{ }^{\circ} \mathrm{C}$ por $5 \mathrm{~min}$. A primeira fita do cDNA foi mantida em freezer $-80^{\circ} \mathrm{C}$.

\subsection{6 - Sequenciamento de DNA}

As amostras do gene e cDNA das $\beta$-xilosidases de $H$. grisea foram sequenciadas em um sequenciador automático de 96 capilares Megabace (Amersham Biosciences) na Universidade Católica de Brasília (UCB), Campus II, Asa Norte: SGAN 916-Módulo B. No sequenciamento foram utilizados $250 \mathrm{ng}$ de DNA plasmidial e 3,2 @mol dos oligonucleotídeos. Os eletroferogramas resultantes do sequenciamento foram visualizados no programa Bioedit e analisados no programa Eletropherogram quality analysis, por meio da ferramenta de bioinformática: CAP3, Cross-match e PHRED disponíveis na página http://asparagin.cenargen.embrapa.br/phph/. As sequências obtidas foram analisadas, avaliadas quanto a qualidade e foi feita a montagem dos contigs dos fragmentos. As sequências resultantes foram submetidas ao algorítimo BLAST para comparar com as sequências depositadas no banco de dados e analisar a orientação do inserto.

\subsection{7 - Análises das sequências obtidas}

Os contigs disponibilizados pelo CAP3 foram submetidos a comparação com sequências depositadas no GenBank utilizando a ferramenta de alinhamento BLASTn e BLASTp (basic local alignment tool) (http://www.ncbi.nlm.nih.gov/BLAST) para análise dos nucleotídeos e da sequência de aminoacidos, respectivamente. O Software online FGENESH (http://linux1.softberry.com/berry.phtml) foi utilizado para predição de sítios de introns e exons. SignalP4.0 server (http://www.cbs.dtu.dk/services/SignalP/) e NetNGlyc 1.0 Server (http://www.cbs.dtu.dk/services/NetNGlyc/) foram usados para predição de sequencias de peptídeo sinal e sitíos pontenciais para N-glicosilação, respectivamente. A ferramenta Secretome 2.0 foi utilizada para predição de secreção de proteínas por vias não clássicas (http://www.cbs.dtu.dk/services/SecretomeP/).

\subsection{8 - Produção de $\alpha$-L-arabinofuranosidase (ABF3) de $P$. purpurogenum por $P$. pastoris}

O cDNA do gene da ABF3 de P. purpurogenum, clonado no vetor de expressão pPICZA (pPICZA/abf3), foi cedido pelo Dr. Jaime Eyzaguirre (Facultad de Ciencias 
Biológicas, Universidad Andrés Bello, Santiago, Chile). O vetor pPICZA/abf3 foi introduzido em células de E. coli $\mathrm{DH} 5 \alpha$ e os clones obtidos foram selecionados por PCR de colônia utilizando os oligonucleotídeos AOX5 e AOX3 (Tabela 8) para confirmação da presença do inserto.

Posteriormente, um clone contendo o vetor pPICZA/abf foi crescido por 18 horas em meio LB líquido, contendo ampicilina, e submetido a extração de DNA plasmidial em larga escala. O DNA plasmidial (pPICZA/abf) extraído foi linearizado para formação do cassete de expressão e posterior integração no genoma da levedura. $\mathrm{O}$ vetor $\mathrm{pPICZA} / a b f$ foi linearizado com a enzima de restrição SacI e introduzido em células de P. pastoris das linhagens GS115 (his4) e SMD1168 (his4 pep4) por eletroporação. O cassete de expressão linarizado com SacI possuía nas laterais as regiões inciais e terminadoras do promotor AOX1 e assim espera-se que a inserção do cassete no genoma da levedura tenha ocorrido por adição no lócus gênico de $A O X 1$ da levedura, gerando transformantes com crescimento normal em metanol, o que caracteriza os transformantes com fenótipo $\mathrm{Mut}^{+}$.

\subsection{9 - Estratégia para transformação das $\beta$-xilosidases de $H$. grisea $\mathrm{em} P$. pastoris}

Para a transformação das $\beta$-xilosidases de $H$. grisea em $P$. pastoris foram utilizados dois vetores, pHILD2 e pPIC9 (Fig 5 A e B). O cDNA foi clonado após o promotor do gene $A O X 1$ para a construção com o vetor pHIL-D2. Para a construção com o vetor pPIC9, o cDNA foi clonado após o peptídeo sinal, o fator- $\alpha$ de $S$. cerevisiae, que permite a expressão extracelular da proteína recombinante.

\subsection{1 - Construção dos vetores}

\subsubsection{1 - Construção 1 - vetor pHILD2}

Os cDNAs correspondentes as $\beta$-xilosidases A e B $(h x y l A$ e $h x y l B)$ foram amplificados utilizando os oligonucleotídeos específicos descritos na Tabela 7. O produto amplificado foi analisado em gel de agarose 0,8\%, em tampão TEB $(0,5 \mathrm{X})$ e visualizado pela coloração com brometo de etídeo para a confirmação da amplificação. O produto da PCR foi purificado do gel de agarose usando o kit de purificação de DNA genômico Wizard $®$ (Promega Corporation, EUA) de acordo com as instruções do fabricante e utilizados para clonagem no vetor pGEM-T-Easy. A transformação foi confirmada por PCR de colônia utilizando os oligonucleotídeos específicos da Tabela 7. 
Após a confirmação, o DNA plasmidial foi extraído e submetido a digestão com a enzima EcoRI por $3 \mathrm{~h}$ a $37{ }^{\circ} \mathrm{C}$. Após $3 \mathrm{~h}$, o sistema de digestão foi submetido a inativação térmica a $70{ }^{\circ} \mathrm{C}$ por 5 min para a inativação da enzima. O produto da digestão foi analisado em gel de agarose $0,8 \%$ e, posteriormente, o inserto purificado do gel.

O inserto digerido e purificado foi utilizado foi ligado ao vetor de expressão pHIL-D2 na razão de 1:5, utilizando a enzima T4 DNA ligase e tampão desta enzima de acordo com orientações do fabricante (Thermo Scientific) por $2 \mathrm{~h}$ a $22^{\circ} \mathrm{C}$. Posteriormente, $3 \mu \mathrm{l}$ do sistema de ligação foram utilizados para transformação de células de E. coli TOP10, por eletroporação (método descrito anteriormente, item 6.13). Após a transformação, as células foram plaqueadas em placas contendo ampicilina (100 $\mu \mathrm{g} / \mathrm{mL})$. A presença do cDNA no vetor pHIL-D2 foi confirmada através de PCR de colônia com os oligonucleotídeos específicos e com os oligonucleotídeos AOX que se anelam em regiões promotora e terminadora AOX no vetor pHILD2 (Tabela 8). Foi realizada a extração de DNA plasmidial e o DNA extraído foi digerido com EcoRI e analisado com gel de agarose $0,8 \%$ para confirmação da presença do inserto.

Os cassetes de expressão foram submetidos a sequenciamento Universidade Católica de Brasília (UCB) para a análise da orientação correta do inserto (conforme o item 5.16).

\subsubsection{2 - Construção 2 - vetor pPIC9}

Para construção do cassete de expressão utilizando o vetor pPIC9, foi realizada a amplificação dos cDNAs, $h x y l A$ e $h x y l B$, utilizando os oligonucleotídeos específicos, com sequências flanqueadoras contendo os sítios de restrição para as enzimas EcoRI e Not I (Tabela 8). O produto amplificado foi analisado em gel de agarose 0,8\%, em tampão TEB $(0,5 \mathrm{X})$ e visualizado pela coloração com brometo de etídeo para a confirmação da amplificação. O produto da PCR foi purificado usando o kit de purificação de DNA genômico Wizard ${ }^{\circledR}$ (Promega Corporation, EUA) de acordo com as instruções do fabricante e em seguida foi inserido no vetor de clonagem pGEM-TEasy e transformado em E. coli DH5 $\alpha$. A transformação foi confirmada por PCR de colônia.

Alguns clones obtidos na transformação foram escolhidos e cultivados em $5 \mathrm{~mL}$ de meio LB a $37^{\circ} \mathrm{C}$ por $16 \mathrm{~h}$ a $180 \mathrm{rpm}$, posteriormente foi realizada extração de DNA plasmidial. $1 \mu \mathrm{g}$ do DNA plasmidial foi digerido com a enzima de restrição EcoRI e 
NotI a $37^{\circ} \mathrm{C}$ por $3 \mathrm{~h}$. O produto da digestão foi submetido à eletroforese em gel de agarose $0,8 \%$, e o inserto correspondente ao cDNA das $\beta$-xilosidases A e B foram eluídos do gel e utilizados para clonagem no vetor de expressão pPIC9.

O plasmídio pPIC9 $(1 \mu \mathrm{g})$ também foi digerido com as enzimas EcoRI e NotI a $37^{\circ} \mathrm{C}$ por $3 \mathrm{~h}$. O cDNA digerido e purificado foi ligado ao vetor de expressão pPIC9 na razão de 1:5, utilizando a enzima T4 DNA ligase e tampão desta enzima de acordo com orientações do fabricante (Thermo Scientific) por $2 \mathrm{~h}$ a $22{ }^{\circ} \mathrm{C}$. Posteriormente, $3 \mu \mathrm{do}$ sistema de ligação foram utilizados para transformação de células de E. coli TOP10, por eletroporação. Após a transformação, as células foram plaqueadas em placas contendo ampicilina $(100 \mu \mathrm{g} / \mathrm{mL})$. A presença do cDNA no vetor pPIC9 foi confirmada através de PCR de colônia com os oligonucleotídeos específicos e com os oligonucleotídeos AOX que se anelam em regiões promotora e terminadora AOX no vetor pPIC9 (Tabela 8). Foi realizada a extração de DNA plasmidial e o DNA extraído foi digerido com EcoRI e $N o t \mathrm{I}$ e analisado com gel de agarose $0,8 \%$ para confirmação da presença do inserto. Os cassetes de expressão foram submetidos a sequenciamento na Universidade Católica de Brasília (UCB) para a análise da sequência do inserto (conforme o item $5.16)$.

\subsection{0 - Preparo de células competentes de $\boldsymbol{P}$. pastoris}

As células de P. pastoris foram inoculadas em $5 \mathrm{~mL}$ de meio YPD em tubo cônico de $50 \mathrm{~mL}$ e incubadas a $30{ }^{\circ} \mathrm{C}$ por $18 \mathrm{~h}$ sob agitação de $200 \mathrm{rpm}$. Após este período, $100 \mu \mathrm{L}$ do pré-inóculo foi adicionado a $500 \mathrm{~mL}$ de meio YPD em erlenmeyer de $2 \mathrm{~L}$ e incubado sob as mesmas condições do pré-inóculo até atingir a $\mathrm{DO}_{600}$ entre 1.3 a 1.4. Posteriormente, as células foram coletadas por centrifugação a $1.500 \mathrm{~g}$ por $5 \mathrm{~min}$ a $4{ }^{\circ} \mathrm{C}$ e ressuspensas em $500 \mathrm{~mL}$ de água destilada estéril gelada. Em seguida, foram submetidas à centrifugação nas mesmas condições anteriores e ressuspensas em $250 \mathrm{~mL}$ de água destilada estéril gelada. Posteriomente, as células foram centrifugadas e ressuspensas em $20 \mathrm{~mL}$ de sorbitol $1 \mathrm{M}$ gelado, posteriormente foram centrifugadas e ressuspensas em $1 \mathrm{~mL}$ de sorbitol $1 \mathrm{M}$ gelado para um volume final de aproximadamente 1,5 mL. As células competentes foram utilizadas imediatamente na transformação, pois apesar das células poderem ser congeladas, sua eficiência diminui significativamente. 


\subsection{1 - Transformação de $P$. pastoris}

As linhagens de $P$. pastoris GS115 e SMD1168 foram utilizadas neste trabalho como células hospedeiras nos experimentos de transformação com o vetor de expressão pPICZA/Ppabf, pHILD2 e pPIC9 (Invitrogen). Os vetores foram introduzidos em células de $P$. pastoris utilizando o protocolo de eletroporação conforme o manual da Invitrogen (Original Pichia Expression Kit, número do catálogo: K1710-01), utilizando o aparelho GenePulser (Bio-Rad). Para a transformação, $80 \mu \mathrm{L}$ de células competentes foram homogeneizadas com $10 \mu \mathrm{g}$ de DNA plasmidial (previamente linearizado) em 10 $\mu \mathrm{L}$ de $\mathrm{H}_{2} \mathrm{O}$ MiliQ. A mistura foi transferida para uma cubeta de 0,2 $\mathrm{cm}$ gelada e incubada em gelo por $5 \mathrm{~min}$. As células foram submetidas à eletroporação de acordo com as instruções do fabricante para $P$. pastoris. Imediatamente após o choque, foi adicionado $1 \mathrm{~mL}$ de sorbitol $1 \mathrm{M}$ gelado, e o conteúdo da cubeta foi transferido para um tubo cônico de $15 \mathrm{~mL}$. Em seguida, foi incubada a $30{ }^{\circ} \mathrm{C}$, sem agitação, por $4 \mathrm{~h}$. Um volume de 10, 25, 50, 100 e $200 \mu \mathrm{L}$ foi semeado em placas de Petri contendo meio YPDS (1\% de extrato de levedura, $2 \%$ de peptona, $2 \%$ de glicose, $2 \%$ de ágar, $1 \mathrm{M}$ de sorbitol, $100 \mathrm{mg} / \mathrm{mL}$ de Zeocina) com zeocina para seleção dos transformantes contento do vetor pPICZA/Ppabf e os transformantes contendo os vetores pHILD2 e pPIC9 foram semeados em placas de Petri contendo meio MD, sem histidina, para seleção dos transformantes contendo a marca auxotrófica HIS4. O crescimento das colônias ocorreu a $28{ }^{\circ} \mathrm{C}$ por 3 a 4 dias. A zeocina é fotossensível, para evitar a degradação, as placas contendo foram cobertas por papel alumínio.

\subsection{2 - Seleção dos transformantes produtores das enzimas recombinantes em placa do tipo Deep Well}

As colônias de $P$. pastoris obtidas na transformação foram selecionadas inoculando as leveduras em meio líquido BMGY em placas do tipo Deep well (placa de 96 poços com fundo redondo e com capacidade de $2 \mathrm{~mL}$ ). Foram selecionados 95 transformantes de cada construção e um controle negativo. Em cada poço foram adicionados $1 \mathrm{~mL}$ de meio BMGY e uma colônia isolada. As placas foram vedadas com filme plástico, foi feita uma perfuração com agulha para uma melhor oxigenação das colônias e incubadas por $24 \mathrm{~h}$ a $28{ }^{\circ} \mathrm{C}$ a $200 \mathrm{rpm}$ para crescimento das células. Após este período as células foram centrifugadas por 15 min a $3000 \mathrm{~g}$, ressuspensas em água estéril gelada e posteriormente, centrifugadas por $15 \mathrm{~min}$ a $3000 \mathrm{~g}$ e finalmente ressuspensas em meio BMMY, sendo posteriormente incubadas por quatro dias a $28{ }^{\circ} \mathrm{C}$ 
para a indução da produção da enzima recombinante na presença de metanol, sendo que a cada 24 h foi acrescentado metanol para uma concentração final de 0,5\%. Após este período as células foram centrifugadas por $15 \mathrm{~min}$ a $3000 \mathrm{~g}$ e o sobrenadante coletado para análise de atividade enzimática conforme descrito no item 5.4. Os transformantes que obtiveram os maiores valores de atividade foram submetidos ao PCR de colônia de leveduras.

\subsection{3 - PCR de colônia de levedura}

A integração do cassete de expressão no genoma da levedura foi confirmada pela amplificação do lócus AOX1 por PCR de colônia de levedura.

\subsection{1 - Extração do DNA da levedura}

O procedimento foi realizado pelo tratamento prévio da levedura com SDS, sendo suficiente para a extração de DNA cromossômico de células de levedura. Para melhor eficiência da extração foi necessário trabalhar com células frescas. As células que permaneceram por muito tempo na geladeira não apresentaram boa extração por este método. Colônias de leveduras transformadas foram ressuspensas em um volume de $30 \mu \mathrm{L}$ de SDS 0,2 \% e submetidas a agitação intensa por aproximadamente 20 segundos. Em seguida, a mistura foi incubada por $4 \min$ a $90{ }^{\circ} \mathrm{C}$ e submetida à centrifugação por $1 \mathrm{~min}$ a $3000 \mathrm{~g}$. Posteriormente o sobrenadante foi transferido para um novo tubo e estocado a $-20{ }^{\circ} \mathrm{C}$.

\subsection{2 - Reação de PCR}

A PCR foi realizada em um termociclador (Bio-Rad T-100 Thermal Cycler). Foram utilizados oligonucleotídeos para amplificação do lócus AOX1. A reação foi feita para um volume final de $50 \mu$ l, incluindo, $1 \mu$ do DNA genômico extraído, $5 \mu l$ do tampão da enzima (10X), 1,5 $\mu \mathrm{l}$ de $\mathrm{MgCl}_{2}(50 \mathrm{mM}), 1 \mu \mathrm{l}$ da mistura de $10 \mathrm{mM}$ dNTPs (dCTP, dGTP, dATP, dCTP), 0,75 $\mu \mathrm{l}$ de cada oligonucleotídeo a $10 \mu \mathrm{m}$ e $0,2 \mu \mathrm{l}$ da enzima taq DNA polimerase (thermo scientific) e 0,25 $\mu$ l de Triton X-100 25\% para um concentração final de $0,05 \%$. Foi realizada uma curva para determinação da melhor concentração de Triton X-100 e SDS na reação. A adição de Triton X-100 permitiu a amplificação em concentrações elevadas de SDS. As amplificações foram realizadas nas seguintes condições: desnaturação inicial $\left(95{ }^{\circ} \mathrm{C}-5 \mathrm{~min}\right)$, desnaturação $\left(95{ }^{\circ} \mathrm{C}-1\right.$ min), anelamento $\left(55^{\circ} \mathrm{C}-1: 30 \mathrm{~min}\right)$, extensão $\left(72{ }^{\circ} \mathrm{C}-2: 30 \mathrm{~min}\right)$ e extensão final $(72$ $\left.{ }^{\circ} \mathrm{C}-10 \mathrm{~min}\right)$. 
5.24 - Produção das enzimas recombinantes em frasco (adaptado do Manual do Kit de Expressão em $P$. pastoris).

Os melhores produtores da enzima recombinante na seleção em placas deep well e que amplificaram no PCR de colônia de levedura foram selecionados e testados quanto à capacidade de produção enzimática em frascos erlenmeyer de $250 \mathrm{~mL}$, contendo $25 \mathrm{~mL}$ de meio BMGY-U para crescimento das células. As culturas foram incubadas a $28{ }^{\circ} \mathrm{C}$ com agitação constante de $200 \mathrm{rpm}$ até atingirem a $\mathrm{DO}_{600}$ de 5 . As células foram centrifugadas a $3000 \mathrm{~g}$ durante $15 \mathrm{~min}$, lavadas com água destilada estéril e ressuspensas no meio BMMY-U. As colônias foram incubadas a $28{ }^{\circ} \mathrm{C}$, sendo que a cada a cada $24 \mathrm{~h}$ foi acrescentado metanol para uma concentração final de $1 \%$ e retiradas alíquotas de $1 \mathrm{~mL}$ para análise da cinética de produção. As alíquotas foram submetidas à centrifugação a $10.000 \mathrm{~g}$ durante $10 \mathrm{~min}$ e o sobrenadante coletado para dosagem de atividade enzimática, conforme descrito no item 5.4 e análise do perfil proteíco.

\subsection{5 - Otimização da produção de HXYLA por $P$. pastoris em frasco por meio de} planejamento fatorial $2^{3}$.

Foi proposto realizar um planejamento experimental com um transformante produtor de HXYLA, seguindo delineamento central composto rotacional (DCCR) $2^{3}$ com seis repetições no ponto médio. Os seguintes fatores foram analisados: concentração de fonte de carbono (Metanol), concentração de fonte de nitrogênio (extrato de levedura:uréia) e $\mathrm{OD}_{600}$ inicial. Os limites dos níveis dos parâmetros analisados foram estabelecidos conforme dados da literatura para produção de enzimas lignocelulolíticas em $P$. pastoris. Os experimentos foram conduzidos em $25 \mathrm{~mL}$ de meio BMMY-U em erlenmeyer de $250 \mathrm{~mL}$ seguindo o protocolo descrito no item 5.24 obdecendo os valores dos níveis dos parâmetros e matriz do planejamento fatorial $2^{3}$ apresentados na tabela 9 e 10 . 
Tabela 9 - Variáveis independentes, níveis e valores reais utilizados para composição do DCCR.

\begin{tabular}{c|ccccc}
\cline { 2 - 6 } & \multicolumn{5}{|c}{ Níveis } \\
\hline Parâmetros & $\mathbf{- 1 , 6 8}$ & $\mathbf{- 1}$ & $\mathbf{0}$ & $\mathbf{+ 1}$ & $\mathbf{+ 1 , 6 8}$ \\
\hline Metanol & 0,23 & 0,60 & 1,15 & 1,70 & 2,07 \\
\hline Fonte de nitrogênio & 0,69 & 1,40 & 2,45 & 3,50 & 4,21 \\
\hline OD $_{\mathbf{6 0 0}}$ inicial & 1,13 & 3,00 & 5,75 & 8,50 & 10,37 \\
\hline
\end{tabular}

Tabela 10 -DCCR da otimização do meio de indução da produção de HXYLA por $P$. pastoris.

\begin{tabular}{cccc}
\hline Ensaios & Metanol & Fonte de nitrogênio & OD $_{\mathbf{6 0 0}}$ inicial \\
\hline 1 & + & + & + \\
2 & + & + & - \\
3 & + & - & + \\
4 & + & - & - \\
5 & - & + & + \\
6 & - & + & - \\
7 & - & - & + \\
8 & - & - & - \\
9 & $-1,68$ & 0 & 0 \\
10 & 1,68 & 0 & 0 \\
11 & 0 & $-1,68$ & 0 \\
12 & 0 & 1,68 & 0 \\
13 & 0 & 0 & $-1,68$ \\
14 & 0 & 0 & 1,68 \\
15 & 0 & 0 & 0 \\
16 & 0 & 0 & 0 \\
17 & 0 & 0 & 0 \\
18 & 0 & 0 & 0 \\
19 & 0 & 0 & 0 \\
20 & 0 & 0 & 0 \\
\hline & & &
\end{tabular}

A influência dos parâmetros foi avaliada pela análise dos efeitos principais e de interação entre os parâmetros e foram calculados utilizando o software Statgraphics ${ }^{\circledR}$. $\mathrm{O}$ teste de $t$ de Student foi utilizado para analisar o nível de significância. O ponto coletado para a análise foi o de 96 h. Foi considerado como variável resposta a atividade enzimática de $\beta$-xilosidase em $\mathrm{U} / \mathrm{mL}$. 
Além desses parâmetros, foi avaliado o efeito do $\mathrm{pH}$ inicial do meio de cultura na produção da enzima HXYLA por $P$. pastoris. Foi utilizado o tampão McIlvaine nos pHs 4,0 - 5,0 - 6,0 - 7,0 - 8,0, adicionados ao meio de cultura seguindo o protocolo do item 4.7.2. Também foi considerado como variável resposta a atividade enzimática de $\beta$-xilosidase em $\mathrm{U} / \mathrm{mL}$ e o ponto coletado para a análise foi o de $96 \mathrm{~h}$.

\subsection{5 - Análise de proteína em gel de poliacrilamida desnaturante (SDS-PAGE)}

\subsection{1 - Preparo da amostra de sobrenadante de cultura}

Um volume de $900 \mu \mathrm{L}$ das amostras protéicas foi precipitado na presença de 100 $\mu \mathrm{L}$ de TCA 100\%, homogeneizadas e incubadas em banho de gelo e água por $1 \mathrm{~h}$, em seguida foram submetidas à centrifugação a $8000 \mathrm{~g}$ a $4{ }^{\circ} \mathrm{C}$ durante $10 \mathrm{~min}$. $\mathrm{O}$ sedimento resultante da centrifugação foi lavado três vezes com $500 \mu \mathrm{L}$ de acetona gelada, sendo repetida a centrifugação nas mesmas condições citadas anteriormente. $\mathrm{O}$ sedimento resultante foi ressuspenso em $30 \mu \mathrm{L}$ de tampão de amostra e analisado imediatamente ou estocado a $-20^{\circ} \mathrm{C}$ até a análise em gel SDS-PAGE.

\subsection{2 -Condições da eletroforese em gel de poliacrilamida}

A eletroforese de proteínas foi conduzida em gel desnaturante de poliacrilamida, SDS-PAGE (LAEMMLI, 1970). As amostras do sobrenadante de cultura precipitadas por TCA foram ressuspendidas em tampão de amostra de proteína. Antes da aplicação no gel, as amostras foram fervidas durante $5 \mathrm{~min}$, para a desnaturação das proteínas, e logo em seguida colocadas no gelo. As amostras foram aplicadas em um sistema de gel separador de $13 \%$ e concentrador de $4 \%$. A eletroforese foi realizada por 40 min a 200 V. Como marcador de massa molecular para proteínas foi utilizado o Unstained Protein Molecular Weight Marker (Thermo Scientific).

\subsection{3 - Coloração com Coomassie Blue}

Ao término da corrida eletroforética, as bandas protéicas presentes no gel foram visualizadas após incubação deste por $20 \mathrm{~min}$, sob agitação, na solução corante preparada com Coomassie Blue, seguida pela descoloração incubando o gel por $30 \mathrm{~min}$, sob agitação, na solução descorante. 


\subsection{6 - Zimograma para $\beta$-xilosidase}

O zimograma foi realizado como descrito por YAN et al. (2008). Para realização do ensaio, à enzima purificada $(10 \mu \mathrm{L})$ foi adicionado $10 \mu \mathrm{L}$ do mesmo tampão usado para o SDS-PAGE e o gel foi preparado como descrito anteriormente. Após o término da eletroforese, o gel foi lavado três vezes (cada uma durante $10 \mathrm{~min}$ ) com uma solução de isopropanol (25\%) e quatro vezes (cada uma durante $5 \mathrm{~min}$ ) numa solução de tampão Mcllvaine $(\mathrm{pH} 7,0)$ para se livrar de SDS e permitir a renaturação de proteínas. Em seguida, o gel foi incubado com $40 \mu \mathrm{M}$ de 4-metilumbeliferil- $\beta$-D-xilopiranosido (MUX) preparado em tampão Mcllvaine (pH 7,0) durante 30 min a $50{ }^{\circ} \mathrm{C}$. Finalmente, a detecção da atividade de $\beta$-xilosidase foi examinada por fluorescência do 4metilumbeliferona, que é visualizado sob luz ultravioleta.

\subsection{7 - Purificação das enzimas recombinantes}

\subsection{1 - Purificação por afinidade}

Os sobrenadantes contendo a proteína de interesse, foram colocados em uma matriz de afinidade de íons $\mathrm{Ni}^{2+}$. Em seguida, cada conjunto foi colocado em uma coluna e o produto não ligado à matriz eluído através de lavagens da resina (aproximadamente 10 volumes de coluna) com o tampão, com concentrações crescentes de imidazol (50 mM tampão fosfato de sódio pH 8,0, $300 \mathrm{mM} \mathrm{NaCl}, 10 \%$ glicerol, 5, 10 e $15 \mathrm{mM}$ Imidazol e $6 \mathrm{mM} \beta$-mercaptoetanol). A eluição das proteínas ocorreu com um tampão contendo maior concentração de imidazol (tampão B: $50 \mathrm{mM}$ tampão fosfato de sódio $\mathrm{pH} 8,0,300 \mathrm{mM} \mathrm{NaCl}, 10 \%$ glicerol, $300 \mathrm{mM}$ Imidazol e $6 \mathrm{mM} \beta$ mercaptoetanol). Amostras desse processo foram guardadas para análise da atividade e por SDS-PAGE.

\subsection{2 - Purificação por cromatografia por exclusão de tamanho}

Foi utilizada uma coluna Superdex 75 (10/30) (Pharmacia Biotech). Inicialmente, a coluna foi pré-equilibrada com o tampão Tris-HCL 50 mM pH 7,0 e 100 mM NaCL e a eluição das proteínas ocorreu nesse mesmo tampão, com fluxo de 0,8 $\mathrm{mL} / \mathrm{min}$ e corrida com bombeamento isocrático de 1 volume e meio de coluna. As amostras obtidas foram analisadas em SDS-PAGE 13\%. Antes de aplicar a amostra na coluna foi realizada a concentração em uma membrana da Amicon (Amicon ${ }^{\circledR}$ Ultra-15 centrifugal filter devices with low-binding Ultracel® membranes, User Guide 
MILLIPORE modelo 10.000 MWCO) e coletados até $1 \mathrm{~mL}$ final.

\subsection{8 - Caracterização bioquímica da enzima recombinante (HXYLA)}

Para a caracterização bioquímica foi utilizado o tampão McIlvaine prepado como descrito no próximo item.

\subsection{1 - Preparo da solução tampão McIlvaine (fosfato citrato)}

A solução tampão de Mcllvaine é composta por duas soluções distintas, sendo uma de fosfato de sódio dibásico $(0,2 \mathrm{M})$ e outra de ácido cítrico $(0,1 \mathrm{M})$ (Tabela 11).

Tabela 11 - Preparo para obtenção de 20 mL de tampão McIlvaine

\begin{tabular}{ccc}
\hline $\mathrm{pH}$ & $0,2 \mathrm{M} \mathrm{Na}_{2} \mathrm{PO}_{4}(\mathrm{~mL})$ & $0,1 \mathrm{M}$ ácido cítrico $(\mathrm{mL})$ \\
\hline 3,0 & 04,11 & 15,89 \\
4,0 & 07,17 & 12,29 \\
5,0 & 10,30 & 09,28 \\
6,0 & 12,63 & 07,37 \\
7,0 & 16,47 & 03,53 \\
8,0 & 19,45 & 00,55 \\
\hline
\end{tabular}

\subsection{2 - Determinação do pH e temperatura ótimos}

A influência do pH na atividade da enzima HXYLA foi determinada incubando a enzima com o tampão Mcllvaine variando o pH de 3,0 a 8,0 e Tris-HCl de pH 8,0-9,0. A reação foi realizada seguindo o protocolo descrito no item 5.4. As reações para determinação da temperatura ótima foram realizadas, após a determinação do pH ótimo, através da medição da atividade enzimática variando as temperaturas de 30 a $80{ }^{\circ} \mathrm{C}$. Os resultados foram expressos como atividade relativa, onde o maior valor de atividade foi considerado $100 \%$. Os ensaios foram realizados em triplicata.

\subsection{3 - Determinação da estabilidade da enzima em diferentes temperaturas e pH}

Para estimar a estabilidade em pH, a enzima foi incubada em tampão McIlvaine 5,0, 6,0 e 7,0 a $40{ }^{\circ} \mathrm{C}$ por $48 \mathrm{~h}$. Alíquotas foram retiradas e utilizadas para detecção da atividade seguindo a condição padrão ( $\left.\mathrm{pH} 7,0,50{ }^{\circ} \mathrm{C}, 5 \mathrm{~min}\right)$.

A estabilidade térmica foi investigada por determinação de atividade enzimática residual após pré-incubação a 40,50 ou $60{ }^{\circ} \mathrm{C}$, sem substrato, durante 48 h. Os ensaios de atividade da enzima foram realizados sob as condições padrão $\left(\mathrm{pH} 7,0,50{ }^{\circ} \mathrm{C}, 5\right.$ min). Todos os ensaios foram realizados em triplicata. 


\subsection{4 - Efeito de íons e outros agentes químicos}

O efeito de diferentes íons metálicos e alguns agentes químicos sobre a atividade da enzima HXYLA purificada foi avaliada por pré-incubação da enzima na presença de $5 \mathrm{mM}$ do íon ou agente químico por $1 \mathrm{~h}$ a $40^{\circ} \mathrm{C}$ em tampão de McIlvaine (pH 7,0) e em seguida ensaiando a atividade enzimática residual sob condições padrão e comparado com o controle sem adição. Foram utilizados os cloretos dos íons (alumínio, amônia, bário, cálcio, cobre, lítio, magnésio, mercúrio, prata, sódio e potássio), os sulfetos (manganês, zinco e ferro) e $\beta$-mercaptoetanol, SDS e EDTA. A atividade da enzima sem incubação com o íon ou agente químico foi definida como 100\%. Os ensaios foram realizados em triplicata.

\subsection{5 - Determinação dos parâmetros cinéticos}

Para determinar os parâmetros cinéticos da enzima HXYLA purificada, foi realizado a dosagem da atividade em condições ótimas de temperatura e $\mathrm{pH}$, variando a concentração de substrato (pNPX) de 0,066 a 13,33 mM. Os valores de Km, Vmax foram calculados e representados graficamente de acordo com o método do duplo recíproco descrito por Lineweaver-Burk (LINEWEAVER; BURK, 1934).

O gráfico de Lineweaver-Burk correlaciona linearmente 1/V versus 1/[S], para a determinação dos parâmetros. Na curva de Lineweaver-Burk o ponto no qual a reta toca o eixo das ordenadas corresponde a $1 / \mathrm{V} \max$, já o ponto no qual a reta toca o eixo das abscissas equivale é $1 / \mathrm{Km}$.

\subsection{6 - Determinação da especificidade ao substrato}

As especificidades de substrato da enzima HXYLA foram investigadas utilizando diferentes substratos; incluindo $\rho$-nitrofenil- $\beta$-D-xilopiranosido (pNPX), $\rho$ nitrofenil- $\alpha$-L-arabinofuranósido (PNPA), $\rho$-nitrofenil- $\beta$-D-glucopiranósido (PNPG) (Sigma, St. Louis, MO, EUA) e a hidrólise foi realizada seguindo o realizado no ensaio pNPX. A atividade de celulase foi determinada utilizando papel de filtro Whatman no. 1, carboximetilcelulose (CMC) e celulose microcristalina (Avicel, Sigma). A formação de açúcares redutores foi analisada pelo método do DNS seguindo o protocolo estabelecido por CARVALHO (2008). Uma unidade (U) foi definida como a quantidade de enzima que pode libertar um $\mu$ mol de açúcares redutores por minuto nas condições do ensaio. 
Também foram utilizados a arabinoxilana de trigo, xilobiose, xilotriose, xilotetraose da Megazyme (Bray, Co. Wicklow, Irlanda) e xilana beechwood e xilana oat spelt (Sigma).

\subsection{7 - Efeito da xilose sobre a atividade da enzima recombinante HXYLA}

A influência de várias concentrações de xilose sobre a atividade HXYLA foi determinada pela adição de $100 \mu l$ de xilose com concentrações finais de 10-1000 mM. A solução de xilose foi preparada em tampão de Mcllvaine $(\mathrm{pH} 7,0)$ e após a adição da enzima a solução foi mantida a $40{ }^{\circ} \mathrm{C}$ durante $1 \mathrm{~h}$. Para determinar o tipo de inibição, as constantes cinéticas foram determinadas a partir de experimento utilizando a concentração de inibidor (xilose) de $500 \mathrm{mM}$ e a concentrações de substrato variando de 0,066 a 13,33 mM sob condições de ensaio padrão. Os valores de Km e Vmax foram calculados de acordo com Lineweaver-Burk. O valor de $\mathrm{K} i$ foi definido pela quantidade de xilose necessária para uma inibição de 50\% da atividade HXYLA. Os experimentos foram realizados em triplicata.

\subsection{9 - Hidrólise de xilanas comerciais, medula de cana-de-açúcar e BCA pré- tratado por explosão a vapor}

\subsection{1 - Hidrólise de xilanas purificadas comerciais e medula de cana-de-açúcar}

O sinergismo entre HXYLA e HXYN2 foi analisado durante a hidrólise da xilana oat spelt, beechwood e medula de cana-de-açúcar. O sinergismo entre a ABF3 e HXYN2 foi analisado no sinergismo xilana oat spelt e beechwood. As análises seguiram protocolo estabelecido por RAWEESRI; RIANGRUNGROJANA; PINPHANICHAKARN (2008), com algumas modificações. As enzimas foram adicionadas sequencialmente ou simultaneamente. As reações simultâneas foram constituídas de $10 \mathrm{mg}$ de cada substrato em tampão de Mcllvaine pH 7,0 para hidrólise com as enzimas HXYLA e HXYN2 e pH 5,0 para ABF3 e HXYN2 e 0,5 U/mL de cada uma das enzimas em um volume de reação de $1 \mathrm{~mL}$ final. As reações foram incubadas a $50{ }^{\circ} \mathrm{C}$ durante $12 \mathrm{~h}$ e a quantidade de açúcares redutores liberados foram medidos como equivalentes de xilose (MILLER, 1959). As reações sequenciais foram realizadas em duas etapas. A primeira reação continha uma das duas enzimas (HXYLA ou HXYN2 ABF3 ou HXYN2) $(0,5 \mathrm{U} / \mathrm{mL})$ e foi incubada a $50{ }^{\circ} \mathrm{C}$ durante $12 \mathrm{~h}$, em seguida foi realizada fervura por 15 min para inativação da primeira enzima. A segunda reação foi 
realizada por adição de outra enzima e incubou-se a $50{ }^{\circ} \mathrm{C}$ durante mais $12 \mathrm{~h}$. $\mathrm{O}$ grau de sinergia foi definido conforme estabelecido por VAN DYK \& PLETSCHKE (2012), sendo definida como a razão de equivalentes de xilose liberados quando as enzimas foram incubadas simultaneamente ou sequencialmente pela soma dos equivalentes de xilose liberados por cada enzima sozinha.

As leituras foram realizadas no espectrofotômetro a $550 \mathrm{~nm}$. A leitura foi realizada por leitor automático de microplacas modelo ELx800 com 96 poços (Biotek, Winooski, EUA), por meio do programa GEN 5. A quantificação do teor de açúcar redutor (AR) foi ensaiada pelo método do DNS. Para a determinação do teor de AR, primeiramente foi realizada uma curva padrão de xilose nas concentrações de 0,3 a 4,2 $\mathrm{mg} / \mathrm{mL}$ e de acordo com esta as absorbâncias foram convertidas em $\mathrm{mg} / \mathrm{mL}$ de $\mathrm{AR}$ liberados.

\subsection{2 - Hidrólise enzimática do BCA pré-tratado por explosão a vapor para o reaproveitamento da fração de hemicelulose}

As reações de hidrólise enzimática da fração de hemicelulose do BCA foram realizadas utilizando as enzimas ABF3, HXYN2 e HXYLA. Foi utilizado o sobrenadante de cultura de $P$. pastoris no tempo de 96 h de indução para produção de cada enzima. O BCA pré-tratado por explosão a vapor foi cedido pelo Prof. Dr. Luiz Pereira Ramos, da Universidade Federal do Paraná. As condições do pré-tratamento foram $180{ }^{\circ} \mathrm{C}$ por $5 \mathrm{~min}$.

As reações de hidrólise foram realizadas em erlenmeyer de $125 \mathrm{~mL}$ contendo $2 \%$ de BCA pré-tratado por explosão a vapor, as enzimas recombinantes, tampão e água para um volume final de $10 \mathrm{~mL}$. A reação foi mantida a $50{ }^{\circ} \mathrm{C}, \mathrm{pH} 5,0$ por $48 \mathrm{~h}$ sob constante agitação de $140 \mathrm{rpm}$. Após esse período, o sobrenadante da hidrólise foi analisado quanto a concentração de açúcares redutores.

A interação entre as três enzimas recombinantes durante a hidrólise do BCA foi realizada com diferentes concentrações das enzimas ABF3, HXYN2 e HXYLA utilizando do planejamento fatorial completo $2^{3}$, incluindo 6 pontos axiais e 6 repetições no ponto central, totalizando 20 ensaios de acordo com a tabela 13. Os valores das concentrações enzimáticas utilizadas para cada experimento podem ser observados na tabela 12. 
Tabela 12 - Variáveis independentes, níveis e valores reais utilizados para a composição do DCCR para análise da interação entre as três enzimas na hidrólise do BCA

\begin{tabular}{c|ccccc}
\cline { 2 - 6 } & \multicolumn{5}{|c}{ Níveis } \\
\hline Parâmetros & $\mathbf{- 1 , 6 8}$ & $\mathbf{- 1}$ & $\mathbf{0}$ & $\mathbf{+ 1}$ & $\mathbf{+ 1 , 6 8}$ \\
\hline HXYN2 & 96 & 300 & 600 & 900 & 1104 \\
\hline HXYLA & 2,26 & 6 & 11,5 & 17 & 20,74 \\
\hline ABF3 & 0,32 & 1 & 2 & 3 & 3,68 \\
\hline
\end{tabular}

Tabela 13 - DCCR para análise da interação entre as enzimas HXYN2, HXYLA e ABF3 na hidrólise do BCA pré-tratado por explosão a vapor.

\begin{tabular}{cccc}
\hline Ensaios & HXYN2 & HXYLA & ABF3 \\
\hline 1 & + & + & + \\
2 & + & + & - \\
3 & + & - & + \\
4 & + & - & - \\
5 & - & + & + \\
6 & - & + & - \\
7 & - & - & + \\
8 & - & - & - \\
9 & $-1,68$ & 0 & 0 \\
10 & 1,68 & 0 & 0 \\
11 & 0 & $-1,68$ & 0 \\
12 & 0 & 1,68 & 0 \\
13 & 0 & 0 & $-1,68$ \\
14 & 0 & 0 & 1,68 \\
15 & 0 & 0 & 0 \\
16 & 0 & 0 & 0 \\
17 & 0 & 0 & 0 \\
18 & 0 & 0 & 0 \\
19 & 0 & 0 & 0 \\
20 & 0 & 0 & 0 \\
\hline
\end{tabular}

A influência dos parâmetros foi avaliada pela análise dos efeitos principais e de interação entre os parâmetros e foram calculados utilizando o software Statgraphics. O teste de $t$ de Student foi utilizado para analisar o nível de significância. Foi considerado como variável resposta a quantificação de açúcares redutores por DNS dados em $\mathrm{mg} / \mathrm{mL}$. 
Após a análise dos resultados, o ensaio que apresentou maior liberação de açúcares redutores, foi utilizado como padrão para realização de um experimento para detecção da forma de ação das enzimas. Esse experimento ocorreu em uma etapa simultânea e uma sequencial. As análises foram realizadas realizadas em erlenmeyer de $125 \mathrm{~mL}$ contendo $2 \%$ de BCA pré-tratado por explosão a vapor, as enzimas recombinantes, tampão e água para um volume final de $10 \mathrm{~mL}$.

A primeira reação (simultânea) foi mantida a $50{ }^{\circ} \mathrm{C}, \mathrm{pH} 5,0$ por $48 \mathrm{~h}$ sob constante agitação de $140 \mathrm{rpm}$. Após esse período, o sobrenadante da hidrólise das reações simultâneas foram analisados quanto a concentração de açúcares redutores conforme mencionado anteriormente e as reações sequenciais foram submetidas a inativação das enzimas por fervura a $100{ }^{\circ} \mathrm{C}$ por 20 min e submetidas a uma segunda reação a $50{ }^{\circ} \mathrm{C}$, pH 5,0 por 48 h sob constante agitação de $140 \mathrm{rpm}$. Após esse período, o sobrenadante da hidrólise das reações sequenciais foram analisados quanto a concentração de açúcares redutores conforme mencionado anteriormente e seguindo o esquema apresentado na tabela 14.

Tabela 14 - Reações sequenciais e simultâneas com as enzimas HXYN2, HXYLA e ABF3.

\section{Enzimas}

\begin{tabular}{ccc}
\hline Ensaio & 1 $^{\text {a }}$ reação & $\mathbf{2}^{\text {a }}$ reação \\
\hline 1 & ABF3 & - \\
2 & HXYN2 & - \\
3 & HXYLA & - \\
4 & ABF3 + HXYN2 & - \\
5 & HXYN2 + HXYLA & - \\
6 & HXYLA + ABF3 & - \\
7 & HXYN2 + HXYLA + ABF3 & HXYN2 + HXYLA \\
8 & ABF3 & HXYLA \\
9 & ABF3 & ABF3 + HXYLA \\
10 & ABF3 & ABF3 \\
11 & HXYN2 & HXYN2 + ABF3 \\
12 & HXYN2 & ABF3 \\
13 & HXYN2 & HXYN2 \\
14 & HXYLA & HXYLA \\
15 & HXYLA & ABF3 \\
16 & HXYLA & HXYN2 \\
17 & ABF3 + HXYN2 & HXYN2 + HXYLA \\
18 & ABF3 + HXYLA & \\
19 & &
\end{tabular}




\subsection{3 - Avaliação da suplementação de celulases comerciais com as hemicelulases} recombinantes para hidrólise enzimática do $\mathrm{BCA}$

Visando analisar a suplementação de misturas comerciais contendo celulases, foram utilizados as três hemicelulases recombinantes juntamente com celulases de $T$. reesei (ACR -Accellerase ${ }^{\circledR}$ 1500, Dupont, Rochester, NY, EUA). Foi escolhida a concentração que apresentou maior liberação de açúcares redutores por meio do DCCR e os ensaios foram realizados seguindo as condições de $50{ }^{\circ} \mathrm{C}, \mathrm{pH} 5,0,120 \mathrm{rpm}$ por 48 h para ensaios sequenciais e simultâneos com as enzimas ABF3, HXYN2, HXYLA juntamente com a ACR. A concentração de ACR utilizada foi fixada em $5 \mathrm{FPU} / \mathrm{g}$ de substrato, conforme estabelecido por ALVIRA; NEGRO \& BALLESTEROS (2011). Para as reações sequenciais, foi realizada inativação da primeira enzima por fervura por 15 min, e posteriormente, foi adicionada a segunda enzima. Foi realizada nova inbubação por $48 \mathrm{~h}, 50{ }^{\circ} \mathrm{C}, 140 \mathrm{rpm}$. Após o fim da hidrólise, foi dosado açúcar redutor total e a concentração de glicose foi determinada utilizando o kit de glicose oxidase (DOLES Reagentes ${ }^{\circledR}$ ) seguindo as orientações do fabricante.

\subsection{0 - Cromatografia de camada delgada (TLC)}

Para verificar o produto de hidrólise, $5 \mu \mathrm{l}$ das reações de hidrólise foram colocados na placa de sílica-gel (DC-Fertigfolien ALUGRAM®Xtra SIL G/UV254). A fase móvel foi constituída de metanol: butanol: água na proporção de 4: 2: 1 . As bandas foram visualizadas por imersão em solução reveladora $(7,5 \mathrm{~mL}$ de ácido fosfórico, $1 \mathrm{ml}$ de anilina, $50 \mathrm{~mL}$ de acetona e $1 \mathrm{~g}$ de difenilamina) e posterior incubação a $110{ }^{\circ} \mathrm{C}$ por alguns minutos até o aparecimento das bandas. Como marcadores, foram utilizados $4 \mu \mathrm{l}$ de xilose, xilobiose, xilotriose e xilotetraose a $10 \mathrm{mM}$. 
Resultadose

Disscussãa 


\section{RESULTADOS E DISCUSSÃO}

$\beta$-xilosidases, $\alpha$-L-arabinofuranosidases e endo-xilanases apresentam ação sinérgica na degradação da xilana. As endoxilanases geram extremidades livres em que as $\beta$-xilosidases podem atuar, enquanto a atividade desramificadora das $\alpha$-Larabinofuranosidases removem a arabinose ligadas a cadeia central, o que facilita $\mathrm{o}$ progresso das endo-xilanases e $\beta$-xilosidases (SHARMA et al., 2016b).

Vários trabalhos tem descrito a ação heterosinérgica entre arabinofuranosidases e as enzimas $\beta$-xilosidases e endo-xilanases, que clivam a cadeia principal, melhorando a hidrólise dos substratos (KNOB; TERRASAN; CARMONA, 2010; RAWEESRI; RIANGRUNGROJANA; PINPHANICHAKARN，2008; XIMENES; DE PAULA SILVEIRA; F FILHO, 1996; YANG et al., 2015).

Com base no exposto, foi proposto a produção de hemicelulases recombinantes com atividades distintas para formulação de misturas enzimáticas capazes de hidrolisar a fração de hemicelulose do BCA pré-tratado por explosão a vapor. Para facilitar a compreensão, os resultados foram divididos da seguinte forma:

6.1 - Produção de uma endoxilanase de H. grisea por P. pastoris;

6.2 - Produção de uma arabinofuranosidase de $P$. purpurogenum por P. pastoris;

6.3 - $\beta$-xilosidases de H. grisea (Clonagem e expressão por P. pastoris e caracterização enzimática);

6.4 - Ensaios de sinergismo e hidrólise do BCA.

\section{1 - Produção da endoxilanase 2 (HXYN2) de H. grisea por $P$. pastoris}

O fungo $H$. grisea secreta um amplo espectro de enzimas lignocelulolítícas, incluindo uma endo-xilanase de $23 \mathrm{kDa}$. $\mathrm{O}$ gene que codifica essa endoxilanase de 23 kDa (hxyn2) foi expresso por P. pastoris durante o desenvolvimento da Tese de Doutorado de CARVALHO (2008). No presente trabalho, foi utilizado o clone produtor de HXYN2 cedido por CARVALHO, sendo realizada a produção da enzima recombinante HXYN2, seguindo as condições já estabelecidas.

A indução da produção da HXYN2 recombinante por $P$. pastoris foi realizada e o sobrenadante de cultura apresentou atividade de $270 \mathrm{U} / \mathrm{mL}$ após $96 \mathrm{~h}$ na presença de metanol $0,5 \%$. O sobrenadante de cultura foi submetido à cromatografia de exclusão molecular onde foi possível a separação das proteínas do sobrenadante e purificação da banda de $23 \mathrm{kDa}$ correspondente a HXYN2 em uma única etapa (Fig. 7). 


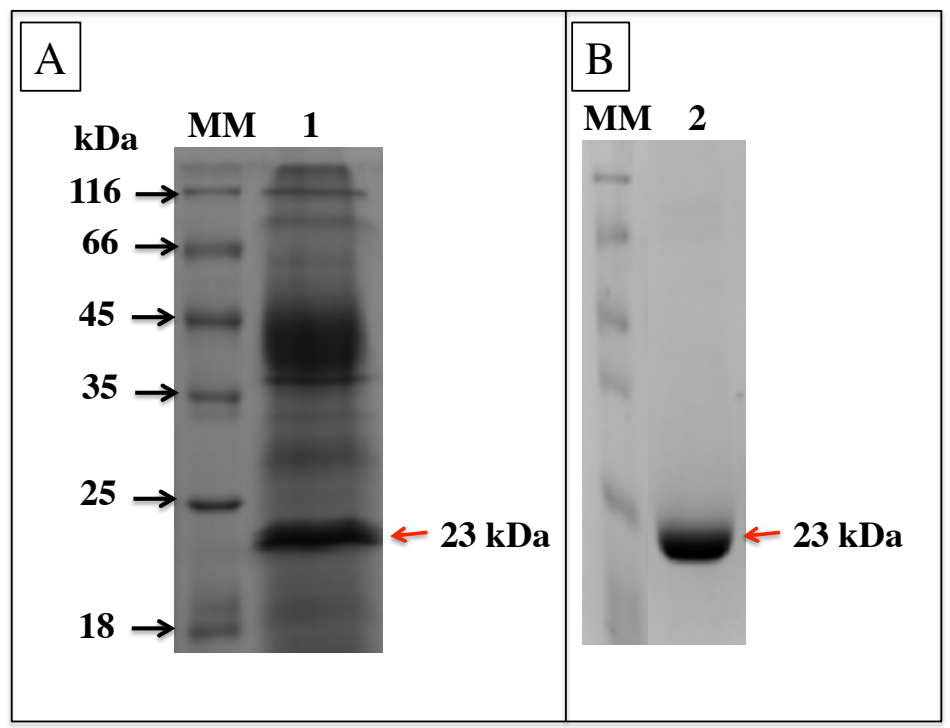

Figura 7 - Análise do perfil de proteínas secretadas pelo transformante produtor de HXYN2 e da purificação da proteína recombinante. A - Perfil de proteínas secretadas no sobrenadante de $P$. pastoris após indução com mentanol 0,5 \% por 96 h. B - Proteína HXYN2 purificada por cromotografia de exclusão molecular. MM - Marcador molecular.

A enzima caracterizada por CARVALHO (2008), apresentou $\mathrm{pH}$ e temperatura ótimos de 6,5 e $60{ }^{\circ} \mathrm{C}$, sendo termoestável a $50{ }^{\circ} \mathrm{C}$ no tempo analisado de $3 \mathrm{~h}$. A enzima purificada no presente trabalho bem como, o sobrenadante de cultura de $P$. pastoris contendo a enzima HXYN2 recombinante, foram utilizados posteriormente para ensaios de sinergismo e hidrólise do BCA.

\section{2 - Produção de uma $\alpha$-L-arabinofuranosidase (ABF3) de $P$. purpurogenum por $P$. pastoris}

A enzima $\mathrm{ABF} 3$, secretada pelo fungo P. purpurogenum, pertence a família GH43, teve o gene expresso por P. pastoris GS115 e foi caracterizada por RAVANAL, CALLEGARI E EYZAGUIRRE (2010). Após a caracterização, foi observado que a enzima apresentava atividades de arabinofuranosidase e $\beta$-xilosidase sendo, portanto, bifuncional.

O cDNA do gene da ABF3 de $P$. purpurogenum, se encontrava clonado no vetor de expressão pPICZA (pPabf3) e foi cedido pela Dra. Cristina Ravanal e Dr. Jaime Eyzaguirre (Facultad de Ciencias Biológicas, Universidad Andrés Bello, Santiago, Chile) para o Laboratório de Biotecnologia de Fungos (UFG) para que fosse possível a transformação de $P$. pastoris e consequentemente a produção da enzima.

A transformação de $P$. pastoris com o vetor de expressão pPabf3 foi realizada após a linearização do cassete de expressão com a enzima $S a c$ I e introduzido em células 
de $P$. pastoris das linhagens GS115 e SMD1168. Os transformantes obtidos foram selecionados quanto a capacidade de produzir e secretar à enzima ABF3 ativa. Essa seleção foi realizada em meio contendo $1 \%$ de metanol como fonte de carbono (BMMY-U), em placas do tipo Deep well. Os sobrenadantes de cultura foram coletados ao final da indução e analisados por dosagem da atividade enzimática (seguindo o item 5.4). Os transformantes que apresentaram atividade mais alta foram submetidos a PCR de colônia de levedura.

Por meio da PCR de colônia dos transformantes selecionados foi possível confirmar a presença do cDNA/abf3 no genoma da levedura. A partir do DNA dos transformantes denominados $\mathrm{pP} / \mathrm{ABF} / \mathrm{GS}$ e o $\mathrm{pP} / \mathrm{ABF} / \mathrm{SM}$ foi possível observar o produto da amplificação de 1705 pb que corresponde a amplificação do vetor pPICZA vazio (325 pb) mais o cDNA da ABF3 (1380 pb) (Fig. 8). Foi utilizado como controle positivo da reação o plasmídeo pPICZA/abf.

Para os transformantes que apresentam o fenótipo $\mathrm{Mut}^{+}$, é possível visualizar duas bandas, uma correspondendo ao tamanho do cassete de expressão e a outra ao gene AOX1 nativo (aproximadamente 2,2 kb). Para o transformante $\mathrm{pP} / \mathrm{ABF} / \mathrm{GS}$ foi possível observar a banda de 2,2 kb e o produto da amplificação do cassete de expressão, confirmando que se trata de um transformante com fenótipo Mut ${ }^{+}$.

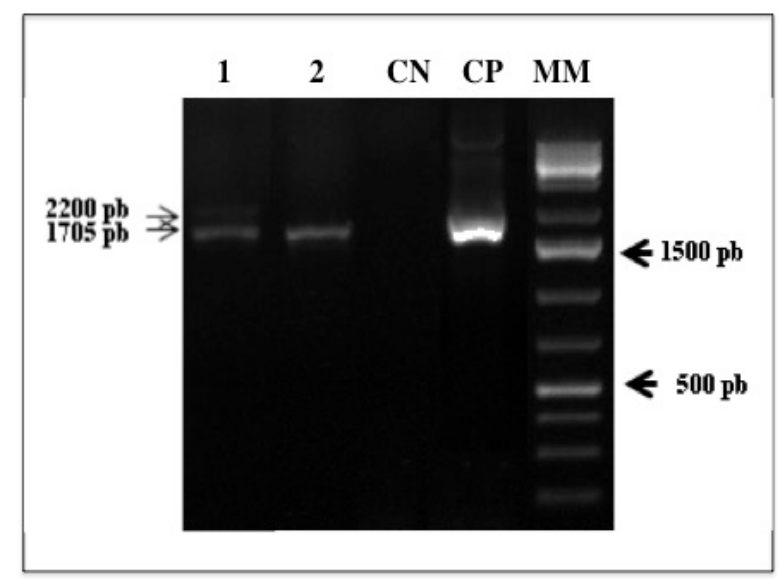

Figura 8 - Análise em gel de agarose $0,8 \%$ dos produtos da amplificação por PCR de colônia de leveduras dos transformantes pP/ABF/GS e pP/ABF/SM. 1: transformante $\mathrm{pP} / \mathrm{ABF} / \mathrm{GS}$; 2: transformante $\mathrm{pP} / \mathrm{ABF} / \mathrm{SM}$; $\mathrm{CN}$ : controle negativo (sem DNA); CP: controle positivo; MM: marcador molecular. Foram utilizado para as amplificações os oligonucleotídeos AOX.

Os transformantes $\mathrm{pP} / \mathrm{ABF} / \mathrm{GS}$ e $\mathrm{pP} / \mathrm{ABF} / \mathrm{SM}$ foram analisados quanto a produção de $\mathrm{ABF} 3$ em frasco (item 5.7.2). O pico de produção de ABF3 pela levedura foi após 
$156 \mathrm{~h}$ com $0,53 \mathrm{U} / \mathrm{mL} \pm 0,002$ para o $\mathrm{pP} / \mathrm{ABF} / \mathrm{GS}$ e de $0,24 \mathrm{U} / \mathrm{mL} \pm 0,01$ para o pP/ABF/SM (Fig. 9 A). As dosagens foram realizadas seguindo o protocolo descrito no item 5.4. O resultado apresentado pelo transformante da linhagem GS115 foi melhor que o apresentado por Ravanal e colaboradores (2012) que obtiveram dados de atividade do transformante produtor de $\mathrm{ABF} 3$ de $0,24 \mathrm{U} / \mathrm{mL}$ também com a linhagem GS115 de $P$. pastoris cultivado sob as mesmas condições de indução.

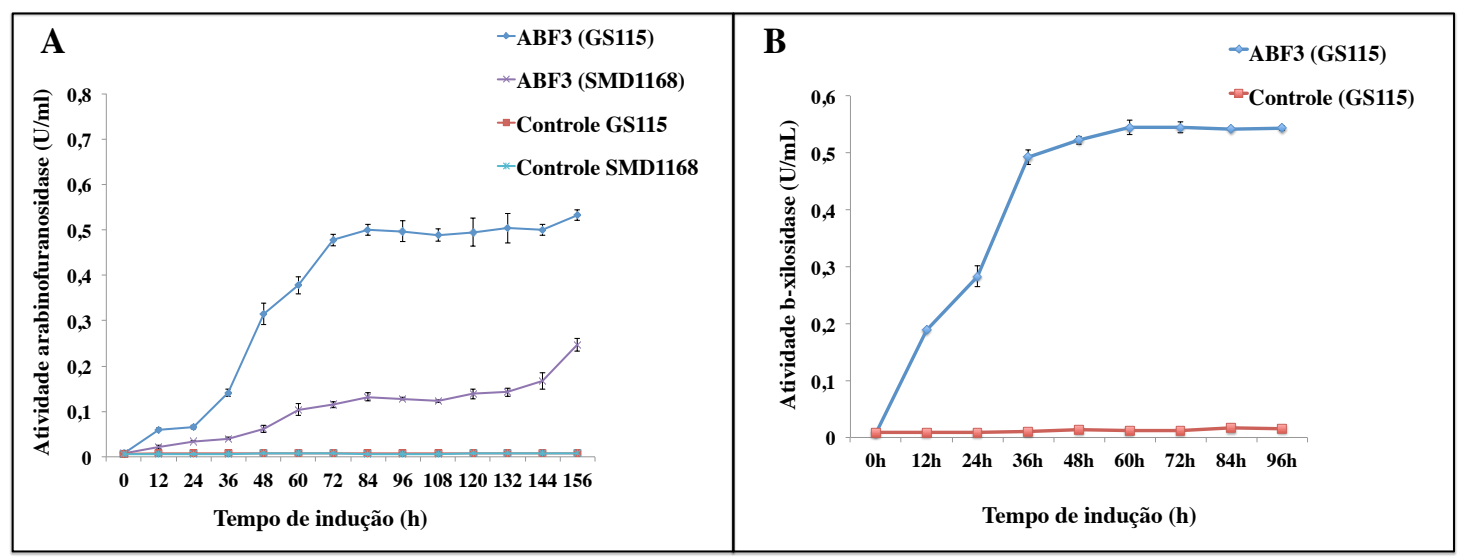

Figura 9 - Cinética da produção da enzima ABF3 de $P$. purpurogenum por $P$. pastoris pelos transformantes $\mathbf{p P / A B F / G S ~ e ~ p P / A B F / S M . ~ A ~ - ~ A n a ́ l i s e ~ d a ~ a t i v i d a d e ~ d e ~}$ arabinofuranosidase, utilizando o substrato pPNA. B- Análise da atividade de $\beta$-xilosidase, utilizando o substrato pPNX. Os controles utilizados são as linhagens GS115 e SMD1168 de $P$. pastoris transformadas com vetor pPICZA/SacI. A indução foi realizada a $28{ }^{\circ} \mathrm{C}, 200 \mathrm{rpm}$ e na presença de $1 \%$ de metanol por $156 \mathrm{~h}$.

Ravanal, Callegari e Eyzaguirre (2012) descreveram que a enzima ABF3 é bifuncional. Para confirmar, foi realizada dosagem de atividade enzimática utilizando o substrato pNPX (Fig. 9 B). Foi observada atividade de $0,54 \mathrm{U} / \mathrm{ml}$, ou seja, similar ao obtido para o substrato pNPA. No trabalho realizado por Ravanal, Callegari e Eyzaguirre (2012) também foi descrito que cinco transformantes analisados apresentaram atividades similares para ambos substratos pNPX e pNPA, corroborando com os resultados apresentados nesse trabalho.

Após a análise da atividade enzimática, o sobrenadante de cultura de $P$. pastoris foi precipitado (item 5.24.2) e submetido a análise do perfil de proteínas secretadas pelo transformante $\mathrm{pP} / \mathrm{ABF} / \mathrm{GS}$ por SDS-PAGE (Fig. 10). No presente trabalho, foi observada uma banda protéica de aproximadamente $60 \mathrm{kDa}$ que, provavelmente, corresponde a ABF3 recombinante. Experimentos para detecção da atividade da banda no gel (zimograma) ou western blotting se fazem necessários, porém não foi possível a realização desses experimentos por falta do substrato (4-metilumbeliferil- $\alpha$-L- 
arabinofuranoside (MUA)) e/ou do anticorpo. Não foi observada a banda no gel do sobrendante de cultura da levedura selvagem (P. pastoris GS115 transformada com o vetor $\mathrm{pPICZA/SacI)} \mathrm{(Fig.} \mathrm{10).}$

A enzima ABF3 nativa apresentou 47,3 $\mathrm{kDa}$, porém foram identificados cinco sítios de N-glicosilação em sua sequência. O trabalho de Ravanal, Callegari e Eyzaguirre (2012) mostrou que a enzima recombinante purificada apresentou massa molecular maior do que a enzima nativa $(\sim 60 \mathrm{kDa})$, e isto foi devido a glicosilação realizada por $P$. pastoris. Mesmo sofrendo modificações pós-traducionais a enzima ainda se manteve ativa e preservou as características bioquímicas da nativa.

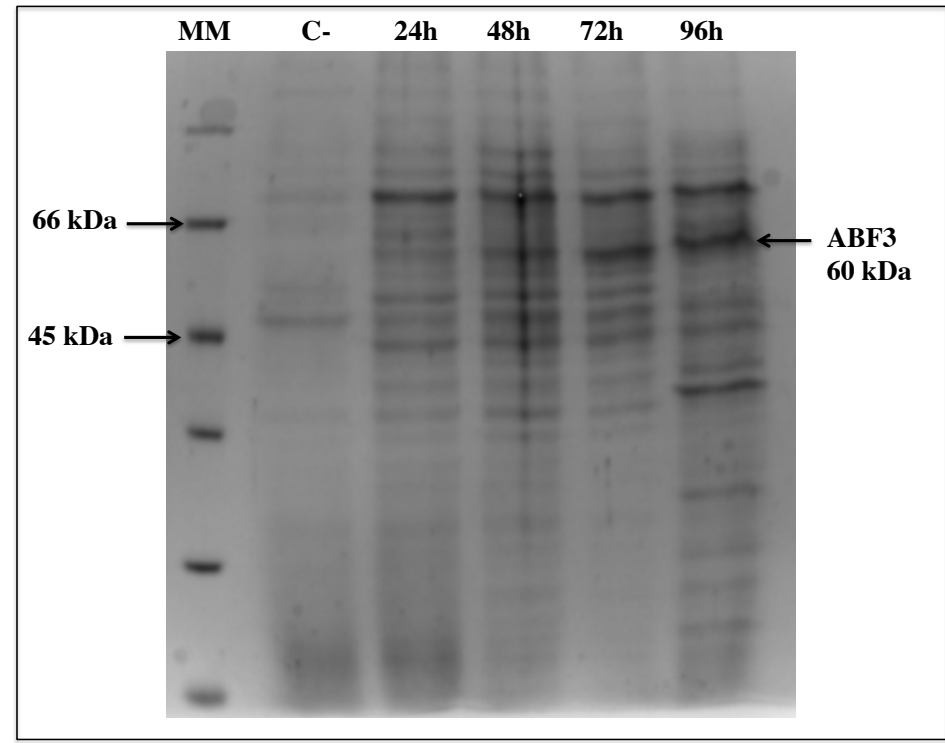

Figura 10 - Perfil eletroforético em gel SDSPAGE 13\% de proteínas secretadas por $P$. pastoris (pP/ABF/GS). MM: Marcador molecular; C-: $96 \mathrm{~h}$ Controle negativo (GS115 selvagem); Cinética da produção de 24 a $96 \mathrm{~h}$. As amostras foram precipitadas com TCA seguindo o protocolo descrito no item item 6.24.2.

Após a confirmação da produção de $\mathrm{ABF} 3$ pela levedura $P$. pastoris foram realizadas algumas tentativas para purificação da proteína utilizando cromatografia de afinidade, visto que a enzima ABF3 foi produzida fusionada a cauda de histidina (histag). Esse procedimento não foi eficiente para purificação. As tentativas de purificação por esse processo não funcionaram, provavelmente, devido ao processamento da enzima, podendo a cauda de histidina não ter ficado exposta para a purificação correta. No trabalho de Ravanal, Callegari e Eyzaguirre (2012) foram realizadas várias etapas para a purificação da ABF3 começando por cromatografia de exclusão de molecular e terminando em uma cromatografia de interação hidrofóbica e o que culminou em um 
baixo rendimento após a purificação $(0,5 \%)$ com $0,04 \mathrm{mg} / \mathrm{mL}$.

Como P. pastoris, normalmente, secreta poucas proteínas endógenas, vários trabalhos tem relatado a utilização do sobrenadante de cultura para diversos fins sem a purificação prévia. Além disso, como relatado anteriormente, a não realização da etapa de purificação das proteínas recombinantes pode contribuir para redução de etapas e custos durante a produção, principamente, as que serão utilizadas em escala industrial (MELLITZER et al., 2012; SPOHNER et al., 2015).

Com base no exposto, foi definido que para as formulações das misturas enzimáticas para hidrólise contendo ABF3 seria utilizado o sobrenadante de cultura de $P$. pastoris sem purificar, apenas concentrado por ultrafiltração em membrana de 10 $\mathrm{kDa}$.

\section{3 - $\beta$-xilosidases de $H$. grisea}

Até o presente momento, foi reportado na literatura a purificação e caracterização de duas $\beta$-xilosidases nativas de $H$. grisea que foram produzidas quando o fungo foi cultivado na presença de xilana oat spelt como única fonte de carbono. As enzimas apresentaram $43 \mathrm{kDa}$ e $50 \mathrm{kDa}$, sendo uma periplasmática e outra associada ao micélio, respectivamente (DE ALMEIDA et al., 1995; IEMBO et al., 2006).

A produção de enzimas do sistema xilanolítico por fungos filamentosos quando cultivados em diferentes resíduos lignocelulósicos tem sido descrita na literatura (DAMASO; ANDRADE; PEREIRA JR, 2000; SAHA; BOTHAST, 1998). Um exemplo disso, é o fungo $H$. grisea que secreta várias dessas enzimas na presença de substratos lignocelulósicos como BCA, FT, SM e PA (CARVALHO, W. R., 2008; DEPAULA; RAMOS; DE OLIVEIRA AZEVEDO, 1999; RAMOS, G. P., 2010). Nenhum trabalho até o momento, havia reportado a produção de ABFs por H. grisea. Dado o exposto, foi proposto a análise da produção tanto de $\beta$-xilosidases quanto de $\alpha$-Larabinofuranosidases pelo fungo $H$. grisea cultivado em diferentes substratos lignocelulósicos.

\subsection{1 - Análise da produção de $\beta$-xilosidases e $\alpha$-L-arabinofuranosidases por $H$. grisea cultivado em diferentes substratos lignocelulósicos.}

A hidrólise de polissacarídeos da parede vegetal é essencial para os fungos obterem energia e nutrientes para o crescimento (KIRIKYALI; CONNERTON, 2015). Como consequência fungos filamentosos tem evoluído de modo a secretar quantidades 
relativamente grandes de enzimas que degradam os carboidratos em açúcares fermentáveis (KRACHER et al., 2014).

Com o objetivo de analisar a produção de XYLs e ABFs pelo fungo H. grisea, os esporos do fungo foram inoculados em MM contendo BCA, FT, SM, PA, FA, xilana beechwood, avicel e CMC (item 5.2). Os melhores indutores da produção de XYLs e $\mathrm{ABF}$ foram o BCA e o FT, sendo que as atividades obtidas para os demais substratos foram baixas comparada com esses dois substratos.

Vários substratos, incluindo os resíduos lignocelulósicos podem ser usados para a produção de hemicelulases (SHARMA et al., 2016b). No presente trabalho, o melhor indutor da produção de XYLs foi o BCA a 3\% após $120 \mathrm{~h}$ de cultivo, com atividade total de $0,19 \mathrm{U} / \mathrm{mL} \pm 0,015$, seguido por FT a $3 \%$ após $72 \mathrm{~h}$ de cultivo, com atividade total de 0,047 $\mathrm{U} / \mathrm{mL} \pm 0,002$ (Fig. $11 \mathrm{~A}$ e $\mathrm{B}$, respectivamente). Esse resultado foi melhor que o apresentado pelo fungo Acremonium sp. que também foi capaz de secretar diversas enzimas do complexo xilanolítico incluindo XYLs $(0,01 \mathrm{U} / \mathrm{mL})$ quando cultivado na presença de BCA 4\% (DE ALMEIDA et al., 2011).

Para produção das ABFs, o melhor indutor foi o FT a 3\% com o pico da atividade em $24 \mathrm{~h}$ de cultivo e com atividade de $0,17 \mathrm{U} / \mathrm{mL} \pm 0,006$ seguido de BCA a 3\% com atividade de 0,05 U/mL $\pm 0,001$ (Fig. $11 \mathrm{C}$ e D, respectivamente). Esse resultado também foi melhor que o obtido por Acremonium $s p$ cultivado na presença de BCA a 4\% (0,02 U/mL) (DE ALMEIDA et al., 2011) ou Trichoderma reesei Rut C-30 quando cultivado na presença de polpa de beterraba (0,02 U/mL) (OLSSON et al., 2003).

Dados da literatura mostram que a fonte de carbono pode influenciar na produção de XYLs e ABFs por fungos e bactérias. Fontes de carbono complexas como, os resíduos lignocelulósicos, tem se mostrado melhores indutores da produção de enzimas do que açúcares solúveis como glicose, xilose e arabinose ou ainda, polissacarídeos purificados como a xilana. Ademais, esses resíduos agroindustriais são uma opção na redução de custos durante a produção dessas enzimas, além de trazer o benefício de sua utilização para o meio ambiente (WAEONUKUL et al., 2008).

Em trabalho realizado com o fungo Aspergillus fumigatus cultivado em diferentes fontes de carbono, foi possível detectar a produção de XYLs quando o fungo foi cultivado em BCA, FT, xilana oat spelt e, principalmente, na cultura com SM (LENARTOVICZ et al., 2003).

Os valores de atividade enzimática dos picos de produção de XYLs e ABFs por H. grisea estão apresentados na tabela 15 . 


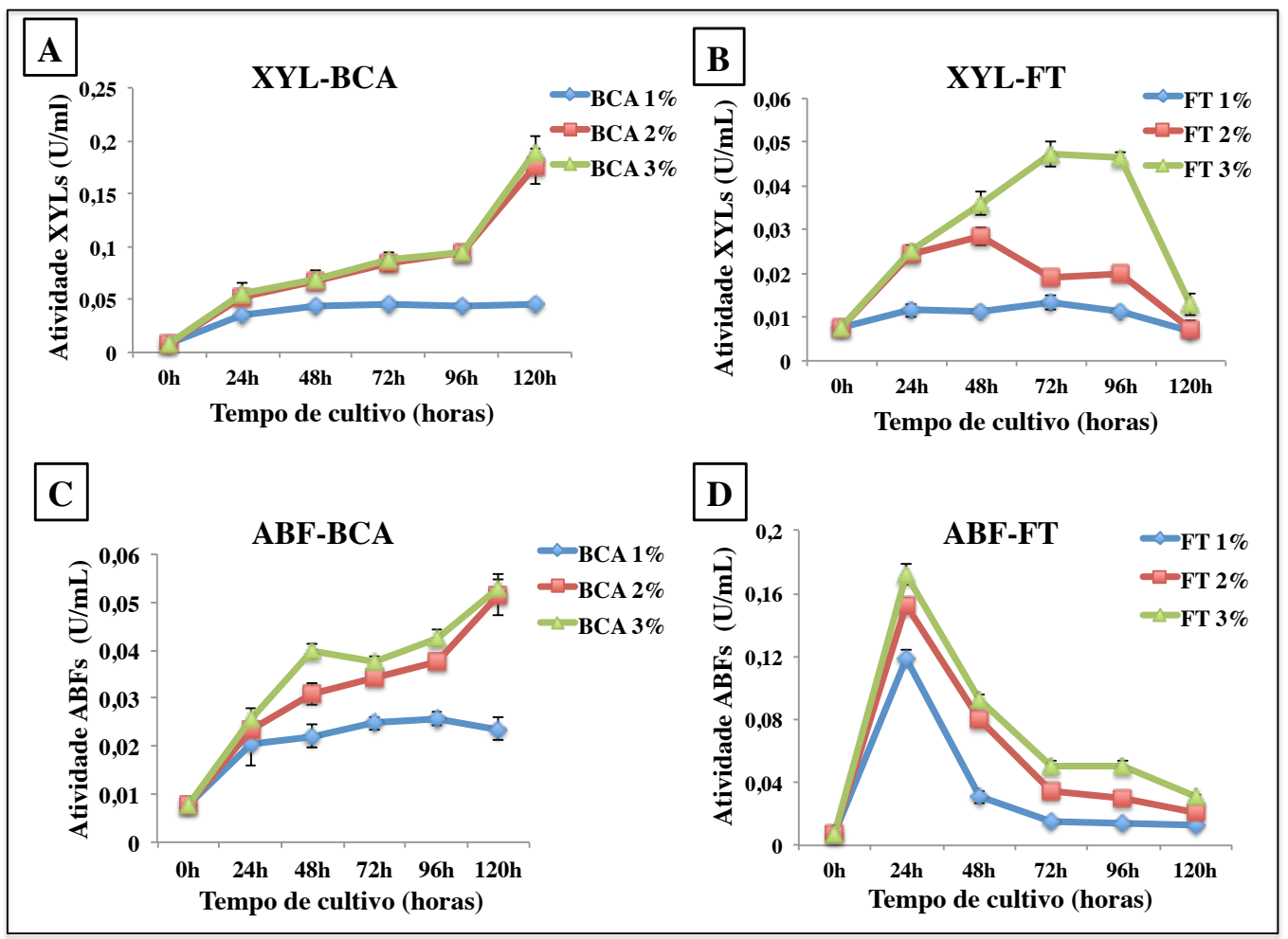

Figura 11 - Cinética da produção de $\beta$-xilosidases e $\alpha$-L-arabinofuranosidases por $\boldsymbol{H}$. grisea cultivado na presença de BCA e FT. A e B - Atividade de XYLs em 1, 2 e 3\% de BCA (A) e 1, 2 e $3 \%$ de FT (B). C e D- Atividade de ABFs em 1, 2 e 3\% de BCA (C) e 1, 2 e $3 \%$ de FT (D). As dosagens foram realizadas utilizando os substratos pNPX e pNPA. Os resultados representam a média e o desvio padrão de duplicatas biológicas dosadas em triplicata.

Tabela 15 - Valores de atividade enzimática para XYLs e ABFs obtidos pelo cultivo de $\boldsymbol{H}$. grisea na presença dos substratos, BCA e FT, como fonte de carbono. Os valores são referentes ao pico de produção das enzimas em cada substrato.

\begin{tabular}{|c|c|c|}
\hline Fonte de Carbono & $\begin{array}{l}\text { XYLs (Tempo de indução/ } \\
\text { U.mL }{ }^{-1} \text { / Desvio Padrão) }\end{array}$ & $\begin{array}{l}\text { ABFs (Tempo de indução/ } \\
\text { U.mL } / \text { / Desvio Padrão) }\end{array}$ \\
\hline BCA $1 \%$ & $120 \mathrm{~h}-0,046 \pm 0,001$ & $96 \mathrm{~h}-0,025 \pm 0,002$ \\
\hline BCA $2 \%$ & $120 \mathrm{~h}-0,17 \pm 0,006$ & $120 \mathrm{~h}-0,051 \pm 0,004$ \\
\hline BCA $3 \%$ & $120 \mathrm{~h}-0,18 \pm 0,005^{*}$ & $120 \mathrm{~h}-0,052 \pm 0,001$ \\
\hline FT $1 \%$ & $72 \mathrm{~h}-0,013 \pm 0,001$ & $24 \mathrm{~h}-0,11 \pm 0,005$ \\
\hline FT $2 \%$ & $48 \mathrm{~h}-0,028 \pm 0,002$ & $24 \mathrm{~h}-0,15 \pm 0,005$ \\
\hline FT $3 \%$ & $72 \mathrm{~h}-0,047 \pm 0,002$ & $24 \mathrm{~h}-0,17 \pm 0,003^{*}$ \\
\hline
\end{tabular}

*maior atividade obtida/tempo/U-mL

Após a análise da produção de XYLs e ABFs pelo $H$. grisea em diferentes fontes de carbono, foi possível determinar os pontos para realização da extração de DNA e RNA, visando a obtenção do cDNA de genes de $\beta$-xilosidases e arabinofuranosidases de $\mathrm{H}$. grisea . 
Com esse objetivo, foram desenhados oligonucleotídeos com base na sequência de ABFs e XYLs de H. insolens (Tabelas 6 e 7). Após análises das sequências de genes desses fungos, foi observado que existe uma alta identidade e similaridade entre as sequências de enzimas lignocelulolíticas produzidas por eles. Um exemplo disso, é a sequência de nucleotídeos de uma $\beta$-glicosidase de $H$. insolens que apresentou $100 \%$ de identidade com o gene que codifica uma $\beta$-glicosidase (BGL4) de $H$. grisea var. IFO 9854 (SOUZA et al., 2014).

Os oligonucleotídeos degenerados desenhados com base na sequência de proteínas de duas $\mathrm{ABFs}$ de $H$. insolens foram utilizados para tentativa de amplificação de genes de ABFs de H. grisea. Foram obtidos vários fragmentos que foram visualizados em gel de agarose, mas nenhum com o tamanho esperado para ABFs (Dados não mostrados). Dado o exposto e devido ao fato da obtenção de genes de $\beta$ xilosidases de $H$. grisea, optou-se por se trabalhar com esses genes ( $\beta$-xilosidases). A partir disso, foi iniciado o processo de clonagem dos genes de XYLs de H. grisea.

\subsection{2 - Clonagem dos genes de duas $\beta$-xilosidases de H. grisea}

Dois genes de XYLs do fungo $H$. grisea foram obtidos por PCR a partir do DNA total do fungo utilizando os oligonucleotídeos da Tabela 7. Foi amplificado um fragmento de aproximadamente $1000 \mathrm{pb}$ para o gene denominado hxylA e $1600 \mathrm{pb}$ para o gene $h x y l B$ (Fig. 12).

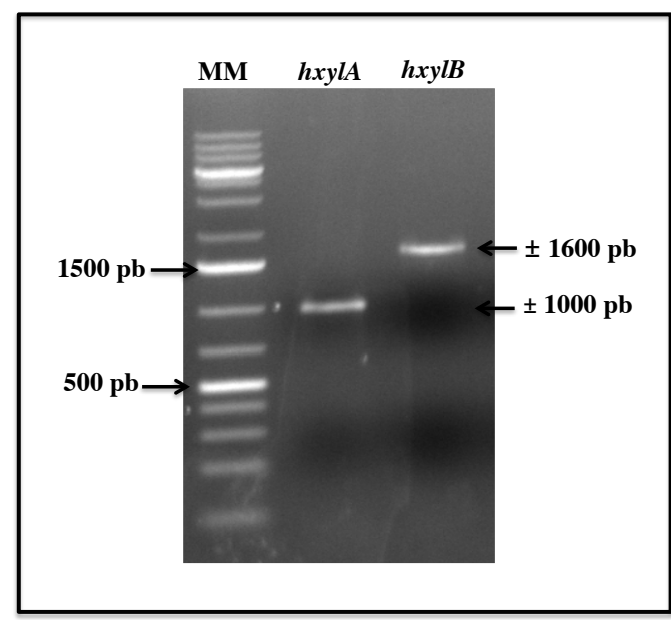

Figura 12 - Análise eletroforética dos produtos de amplificação dos genes hxylA e hxylB de H. grisea obtidos por PCR. (MM) marcador molecular GeneRuler ${ }^{\mathrm{TM}} 1 \mathrm{~Kb}$ bp Plus DNA Ladder (Thermo Scientific).

Após a ligação dos genes no vetor pGEM-T-Easy foi realizada a transformação de E. coli e, posteriormente, a seleção dos clones por PCR de colônia (Fig. 13 B e C) e 
digestão com a enzima de restrição EcoRI para a confirmação da presença do inserto (Fig. 13 D).

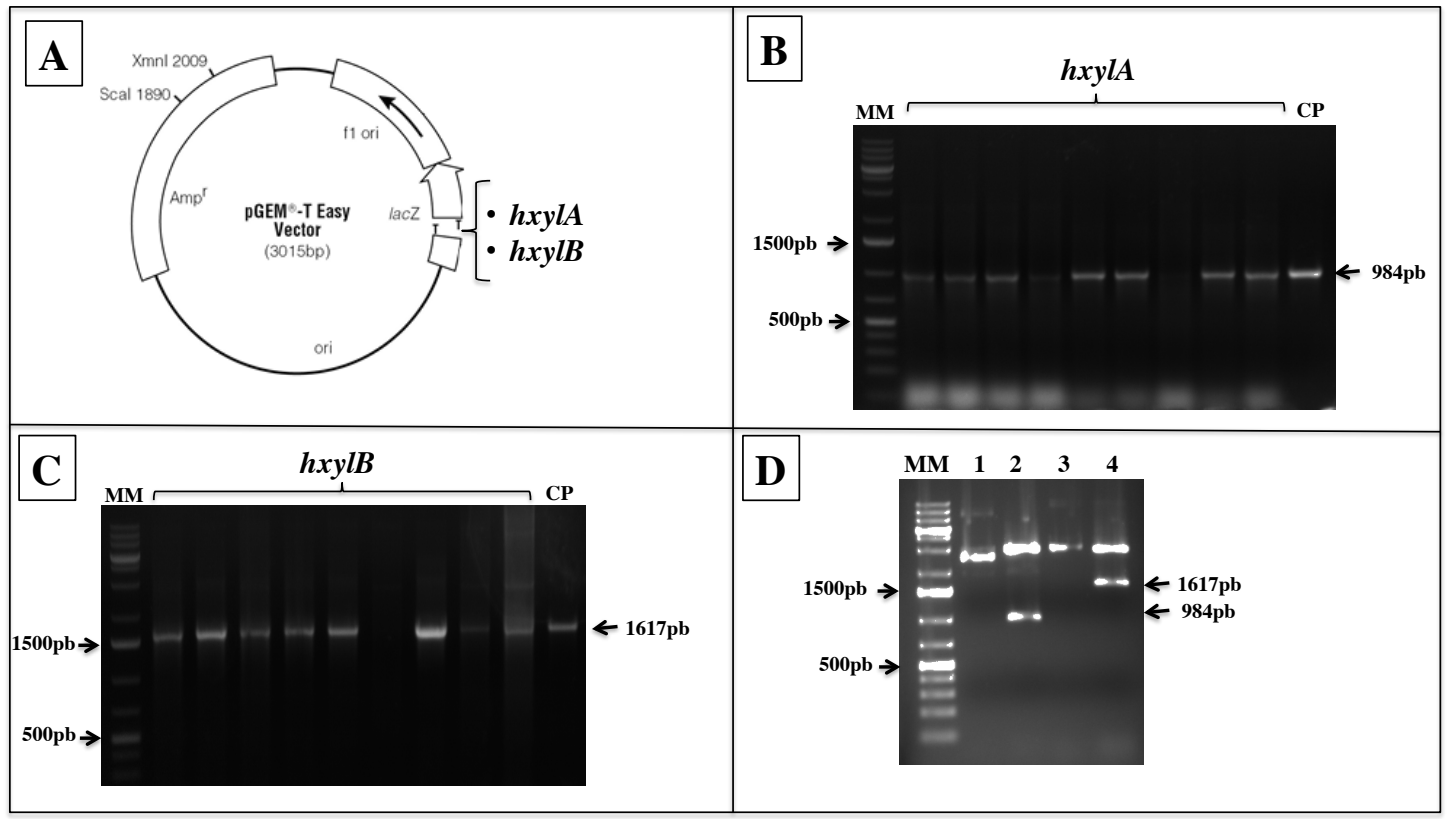

Figura 13 - Estratégia para clonagem dos genes $h x y l A$ e $h x y l B$ no vetor pGEM-T-Easy. (A) Representação da construção do vetor; (B) Análise eletroforética dos clones contendo o gene hxynA amplificados por PCR de colônia. CP: controle positivo; (C) Clones com o gene hxynB; (D) Produto da digestão do vetor pGEM/hxylA e pGEM/hxylB: 1 - Vetor intacto $\mathrm{pGEM} / h x y l A, 2$ - Vetor pGEM/hxylA digerido com EcoRI, 3 - Vetor intacto pGEM/hxylB, 4 Vetor pGEM/hxylB digerido com EcoRI.

\subsubsection{1 - Análise da sequência dos genes hxylA e hxylB}

Os plasmídeos construídos foram submetidos ao sequenciamento e análise das sequências. As sequências obtidas foram analisadas por diferentes ferramentas de bioinformática. As sequências de nucleotídeos de hxylA e hxylB geradas foram depositadas na base de dados do GenBank (NCBI) com o número de acesso KT778266 e KT778267, respectivamente. O tamanho do gene hxylA foi de 984 pb e 1617 pb para o gene $h x y l B$.

As sequências de aminoácidos obtidas pela tradução da sequência de nucleotídeos de hxylA e $h x y l B$, foram analisadas e foi verificado que codificam polipeptídeos de 327 e 538 aminoácidos, respectivamente. Usando a ferramenta Compute pI/Mw (http://web.expasy.org/compute_pi/) foi possível calcular a massa molecular predita e o pI teórico para HXYLA que é de aproximadamente 37 kDa e 5,86, respectivamente, e de $61 \mathrm{kDa}$ e 4.91 para HXYLB. Esses valores de $\mathrm{p} I$ estão de acordo com o encontrado para a maioria das $\beta$-xilosidases fúngicas que exibem pontos isoeléctricos ácidos variando de 4,0 - 5,0 (LAGAERT et al., 2014). 
Em análises realizadas pelo software online FGENESH (http://www.softberry.com/) foi possível verificar que as duas sequências não continham íntrons e o software SignalP 4.1 (http://www.cbs.dtu.dk/services/SignalP/) mostrou que as duas sequências não apresentam peptídeo sinal para secreção. Apesar disso, utilizando a ferramenta online SecretomeP 2.0 Server (http://www.cbs.dtu.dk/services/SecretomeP/), foi possível predizer que as duas $\beta$ xilosidases de $H$. grisea podem ser secretadas por vias de secreção não clássicas.

Pelo algorítimo presente no programa NCBI Conserved Domain Search (http://www.ncbi.nlm.nih.gov/Structure/cdd/wrpsb.cgi) foi possível verificar que as duas $\beta$-xylosidases são membros da Família 43 das glicosil hidrolases (GH43). As $\beta$ xylosidases pertencentes a essa família apresentam massa molecular prevista entre 35$62 \mathrm{kDa}$ e são conhecidas por não apresentarem um sinal de secreção sendo, portanto, enzimas associadas à célula (KIRIKYALI; CONNERTON, 2015).

A análise para sítios de glicosilação utilizando o software NetNGlyc 1.0 (http://www.cbs.dtu.dk/services/NetNGlyc/) mostrou que a enzima HXYLA não apresenta sítio de N-glicosilação, enquanto a HXYLB apresenta 2 possíveis resíduos de asparagina $(\mathrm{N})$ que podem ser glicosilados. Além disso, utilizando o software NetOGlyc 4.0 (http://www.cbs.dtu.dk/services/NetOGlyc/) foi observado que ambas enzimas não apresentam possíveis sítios de O-glicosilação em suas sequências.

As sequências de aminoácidos de HXYLA e HXYLB foram submetidas a um alinhamento pelo algoritmo BlastP. A Tabela 16 mostra a identidade e a similaridade de HXYLA e HXYLB em relação às proteínas que apresentam sequências depositadas, bem como os dados de E-value e número de acesso de cada uma das sequências. As $\beta$ xilosidases de $H$. grisea, HXYLA e HXYLB, apresentaram alta identidade (99\%) com sequências de $\beta$-xilosidases de $H$. insolens Y1, XYL43A e XYL43B (KC962400.1 e KC962401.1), as quais foram utilizadas como molde para desenho dos oligonucleotídeos para amplificação das $\beta$-xilosidases de $H$. grisea (Fig. 12). Ao se comparar sequências de nucleotídeos dos dois fungos foi possível observar que elas apresentam alta identidade como, por exemplo, a sequência de aminoácidos da endoxilanase (HXYN2) de H. grisea (AF155594.1) que apresenta 98\% de identidade com a sequência de uma endoxilanase de H.insolens (X76047.1). 
Tabela 16 - Sequências de $\beta$-xilosidases similares à HXYLA e HXYLB de $H$. grisea. Dados de identidade, similaridade e E-value obtidos por alinhamento local pelo programa BlastP

\begin{tabular}{|c|c|c|c|c|c|}
\hline Organismo & $\begin{array}{l}\text { Identificação da } \\
\text { Sequência }\end{array}$ & $\begin{array}{c}\text { Resíduos } \\
\text { de AA* }\end{array}$ & $\begin{array}{c}\text { Identidade } \\
\text { com } \\
\text { HXYLA }\end{array}$ & $\begin{array}{l}\text { Similaridade } \\
\text { com HXYLA }\end{array}$ & E-value \\
\hline Humicola insolens & AHC72382.1I & 327 & $99 \%$ & $99 \%$ & 0.0 \\
\hline $\begin{array}{c}\text { Chaetomium } \\
\text { thermophilum DSM } 1495\end{array}$ & XP_006691663.1 & 327 & $91 \%$ & $95 \%$ & 0.0 \\
\hline Podospora anserina & CDP24494.1 & 327 & $89 \%$ & $93 \%$ & 0.0 \\
\hline $\begin{array}{c}\text { Myceliophthora } \\
\text { thermophila ATCC } 42464\end{array}$ & XP_003666322.1 & 327 & $87 \%$ & $93 \%$ & 0.0 \\
\hline $\begin{array}{l}\text { Thielavia terrestris NRRL } \\
\qquad 8126\end{array}$ & XP_003651303.1 & 327 & $87 \%$ & $92 \%$ & 0.0 \\
\hline $\begin{array}{c}\text { Neurospora crassa } \\
\text { OR74A }\end{array}$ & XP_965531.3 & 335 & $84 \%$ & $90 \%$ & 0.0 \\
\hline $\begin{array}{l}\text { Fusarium oxysporum } \\
\text { Fo5176 }\end{array}$ & EGU85992.1 & 327 & $85 \%$ & $91 \%$ & 0.0 \\
\hline Fonsecaea pedrosoi & XP_013287823.1 & 326 & $78 \%$ & $85 \%$ & 0.0 \\
\hline Organismo & $\begin{array}{l}\text { Identificação da } \\
\text { Sequência }\end{array}$ & $\begin{array}{l}\text { Resíduos } \\
\text { de AA }\end{array}$ & $\begin{array}{c}\text { Identidade } \\
\text { com } \\
\text { HXYLB }\end{array}$ & $\begin{array}{l}\text { Similaridade } \\
\text { com HXYLB }\end{array}$ & E-value \\
\hline Humicola insolens & AHC72383.1 & 538 & $99 \%$ & $99 \%$ & 0.0 \\
\hline Madurella mycetomatis & KOP48421.1 & 537 & $90 \%$ & $94 \%$ & 0.0 \\
\hline $\begin{array}{l}\text { Myceliophthora } \\
\text { thermophila }\end{array}$ & XP_003663644.1 & 537 & $89 \%$ & $93 \%$ & 0.0 \\
\hline Thielavia terrestris & XP_003653726.1 & 539 & $88 \%$ & $93 \%$ & 0.0 \\
\hline Chaetomium globosum & XP_001224466.1 & 537 & $86 \%$ & $93 \%$ & 0.0 \\
\hline Verticillium alfalfae & XP_003002122.1 & 537 & $83 \%$ & $90 \%$ & 0.0 \\
\hline Colletotrichum sublineola & KDN65014.1 & 537 & $83 \%$ & $91 \%$ & 0.0 \\
\hline Nectria haematococca & XP_003047911.1 & 537 & $81 \%$ & $88 \%$ & 0.0 \\
\hline
\end{tabular}

* Resíduos de aminoácidos 
A HXYLA apresentou alta identidade (91\%) com uma $\beta$-xilosidase hipotética (GH43) de Chaetomium thermophilum var. thermophilum DSM 1495 (EGS22671.1) e uma similaridade de $95 \%$. Ao realizar a pesquisa pelo BlastP, retornaram 100 sequências, onde foi possível observar apenas $\beta$-xilosidases fúngicas, tanto para HXYLA quanto para HXYLB e a menor identidade obtida foi de $68 \%$ com outra sequência depositada no banco de dados.

Algumas sequências obtidas pela análise no algorítimo BlastP foram alinhadas usando o programa CLUSTALX. O dendograma foi construído pelo método de neighbor-joining (SAITOU; NEI, 1987). Limites de confiança foram estimados pela análise de bootstrap (1000 replicatas).

Para a construção do dendograma foi adicionada a sequência de uma celobiohidrolase (CBH1.2) de H. grisea como grupo externo. A análise foi baseada na sequência de aminoácidos HXYLA e HXYLB com sequências de outras 12 enzimas. O dendograma construído para a enzima HXYLA está representado na figura 14.

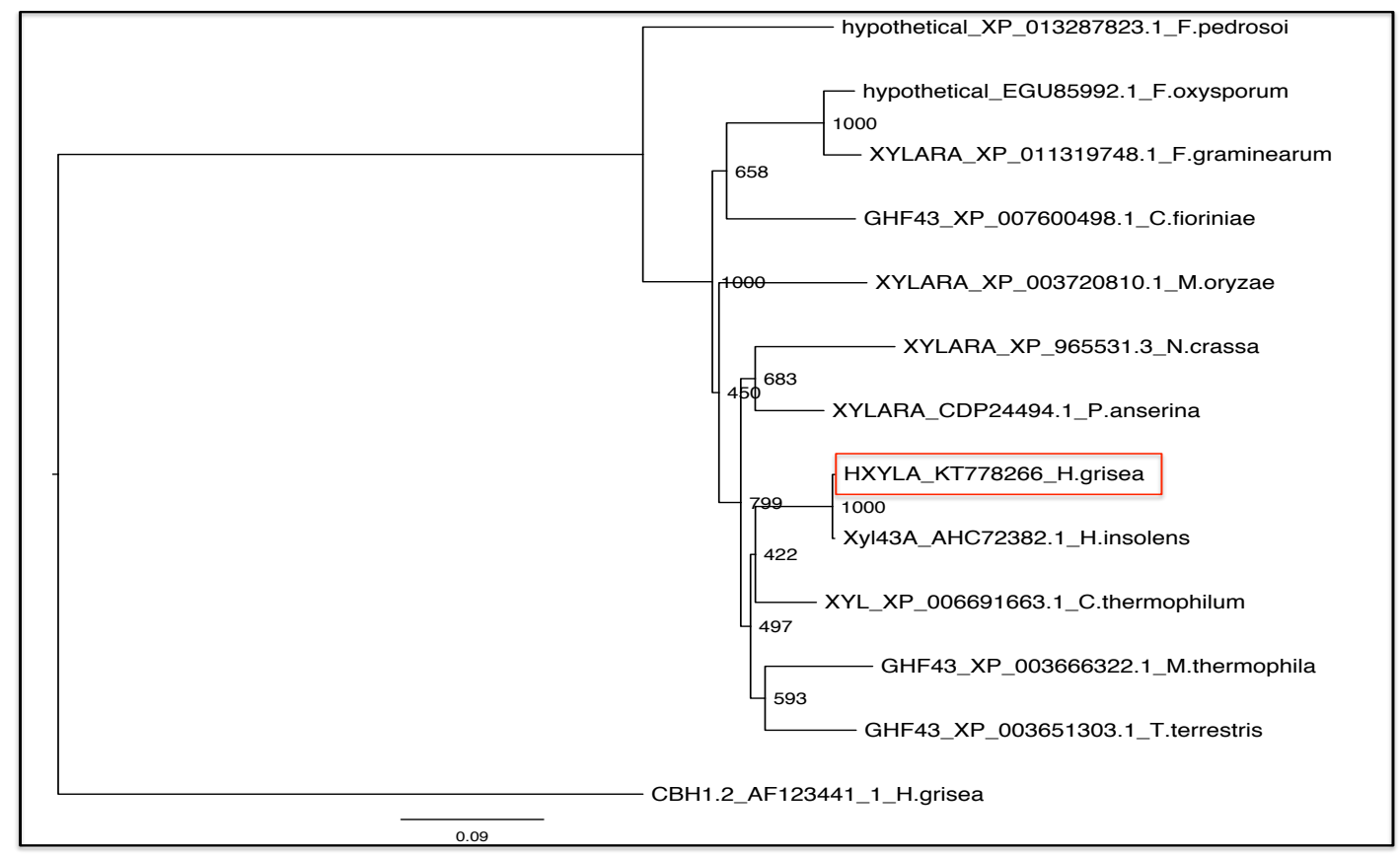

Figura 14 - Dendograma gerado a partir da sequência de HXYLA de $H$. grisea e de sequências obtidas por alinhamento pelo BLASTP e construída pelo método de neighborjoining.

As enzimas que obtiveram valores de identidade e similaridade (Tabela 16) mais próximos foram agrupadas no mesmo ramo. Como as sequências de HXYLA de $H$. grisea e a de $H$. insolens são $99 \%$ similares foram agrupadas no mesmo ramo o que é 
sustentado por um valor de bootstrap de 1000. A sequência de uma $\beta$-xilosidase de Fonsecaea pedrosoi, que é um fungo patogênico humano, ficou isolada em um ramo separado dos demais o que corrobora com os dados de identidade e similaridade mais baixos apresentados na tabela 16 .

O dendograma construído para a enzima HXYLB está representado na figura 15. As enzimas que obtiveram valores de identidade e similaridade (Tabela 16) mais próximos foram agrupadas no mesmo ramo. As sequências de HXYLB de H. grisea e a de $H$. insolens também são $99 \%$ similares e foram agrupadas no mesmo ramo apresentando um valor de bootstrap de 1000. A sequência de uma $\beta$-xilosidase do fungo fitopatógeno Nectria haematococca, que também é conhecido por Fusarium solani, foi o que apresentou mais baixa identidade e similaridade com a HXYLB (Tabela 16).

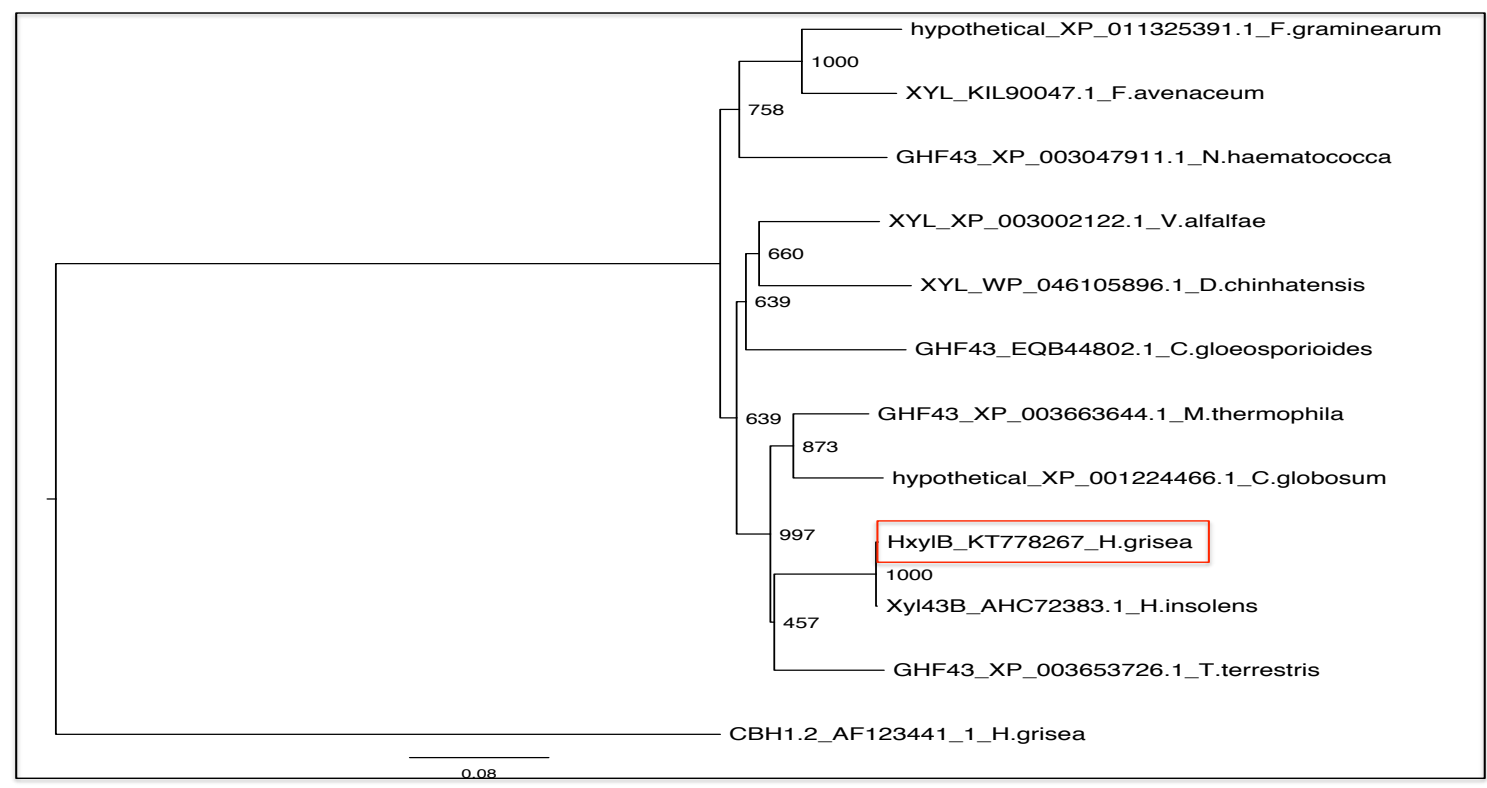

Figura 15 - Dendograma gerado a partir da sequência de HXYLB de $H$. grisea e de sequências obtidas por alinhamento pelo BLASTP e construída pelo método de neighborjoining.

A posição dos resíduos catalíticos do sítio ativo das enzimas HXYLA e HXYLB foi determinada pelo NCBI Conserved Domain Search (Fig. 16 e 17) e o perfil mostrouse bastante conservado quando comparado com outras XYLs. Em geral, os resíduos catalíticos, um nucleófilo e um doador de prótons, das glicosil hidrolases são conservados como Glu ou Asp em GH43. A comparação com sequências de aminoácidos das GH43 identificou três resíduos como possíveis candidatos para 
resíduos catalíticos: Asp-12, Asp-134, e Glu-232 em HXYLA e Asp-15, Asp-130, e Glu-189 em HXYLB de H. grisea (Fig. 16 e 17).

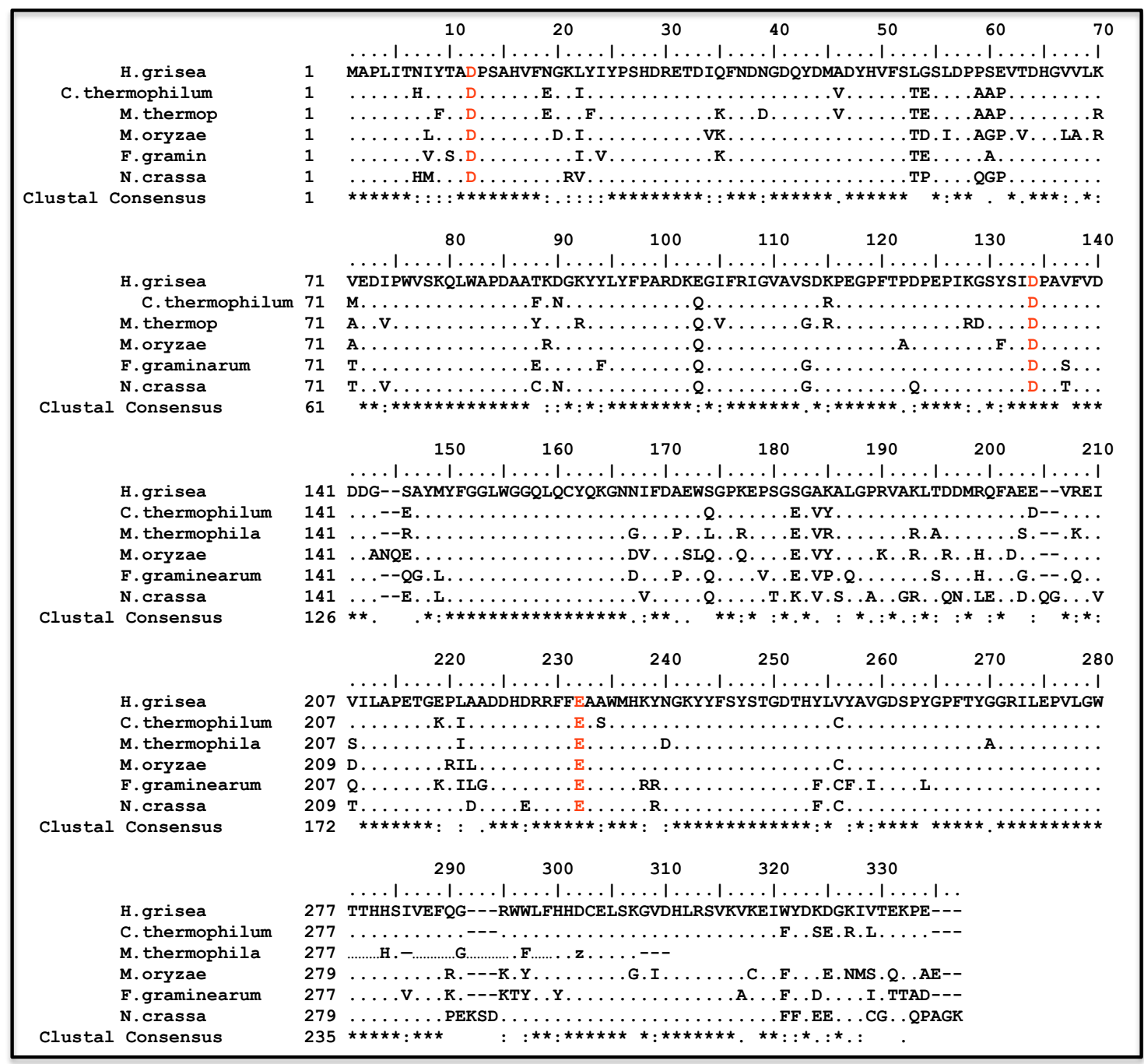

Figura 16 - Alinhamento entre sequências de aminoácidos de HXYLA de $H$. grisea com algumas das sequências de enzimas da família GH43 obtidas por busca pelo algorítimo BlastP. Chaetomium thermophilum (XP_006691663.1), Myceliophthora thermophila (XP_003666322.1), Magnaporthe grisea (XP_003720810.1) , Fusarium graminearum (XP_011319748.1), Neurospora crassa (XP_965531.3). Os números referem-se a resíduos de aminoácidos no início da respectiva linha; os pontos representam os resíduos idênticos ao da sequência base (HXYLA); os traços representam os intervalos (gaps) do alinhamento; todas as sequências são numerados a partir de 1-Met do peptideo. Os resíduos D e E (Asp ou Glu) são aminoácidos do sítio catalítico e estão em vermelho. 


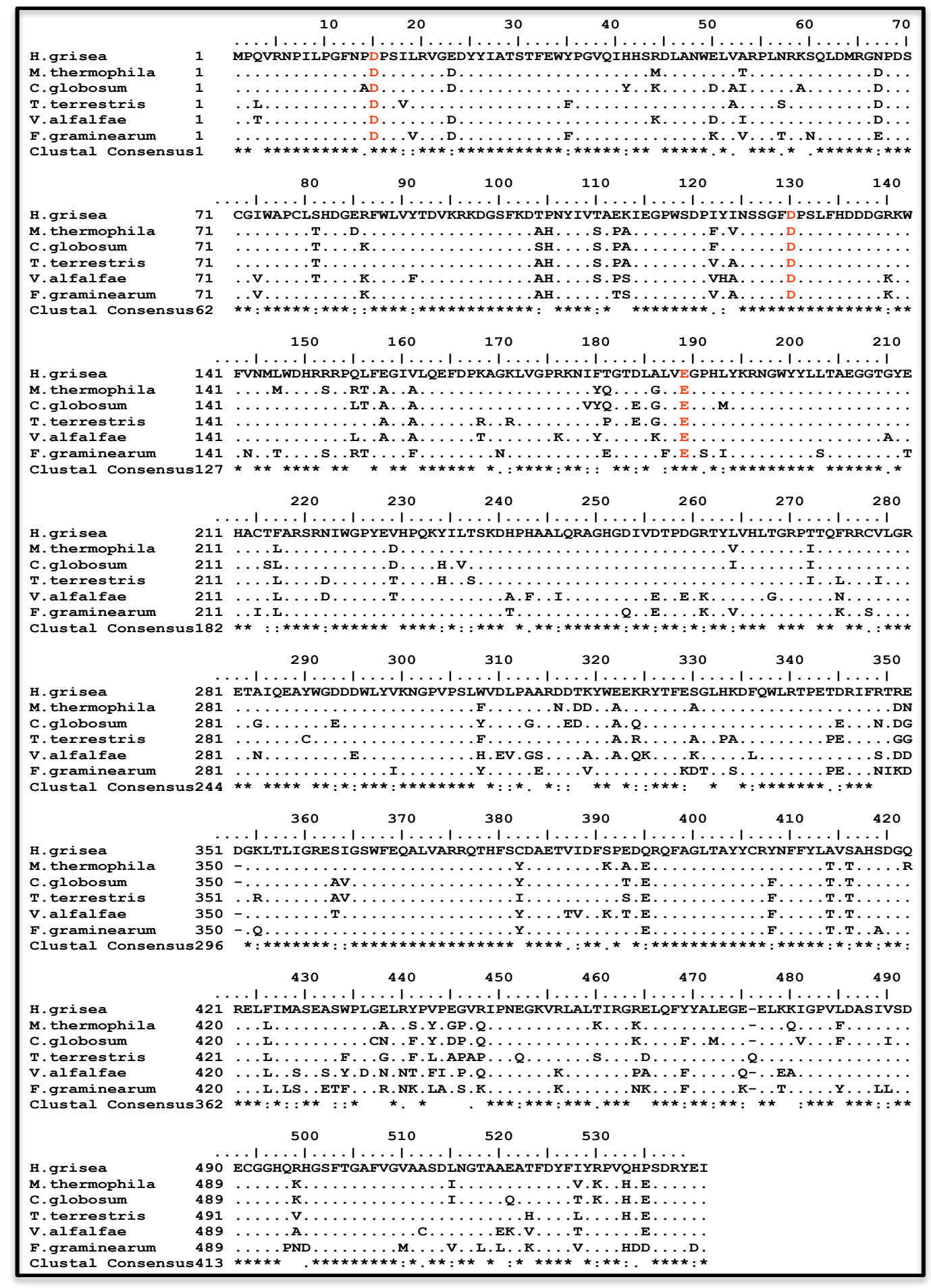

Figura 17 - Alinhamento entre sequências de aminoácidos de HXYLB de $H$. grisea com algumas das sequências de enzimas da família GH43 obtidas por busca pelo algorítimo BlastP. Myceliophthora thermophila (XP_003663644.1), Thielavia terrestres (XP_003653726.1), Chaetomium globosum (XP_001224466.1), Verticillium alfalfae (XP_003002122.1), Fusarium graminearum (XP_011325391.1). Os números referem-se a resíduos de aminoácidos no início da respectiva linha; os pontos representam os resíduos idênticos ao da sequência base (HXYLB); os traços representam os intervalos (gaps) do alinhamento; todas as sequências são numerados a partir de 1-Met do peptideo. Os resíduos D e E (Asp ou Glu) são aminoácidos do sítio catalítico e estão em vermelho. 
As enzimas da família GH43 realizam a reação catalítica por inversão do centro anomérico. Acredita-se que os resíduos catalíticos são formados por uma base de aspartato como nucleófilo e glutamato como um dador de prótons. A reação catalítica é executada como uma única reação de substituição em que um carboxilato (neste caso, o glutamato) protona o substrato, enquanto que o aspartato atua como uma base para ativar uma molécula de água nucleofílica, o que resulta em um ataque nucleófilo, clivagem da ligação glicosídica e inversão no carbono anomérico (JORDAN et al., 2007).

Até o presente momento, somente estruturas tridimensionais para $\beta$-xilosidase bacterianas pertencentes a família GH43 foram resolvidas, porém modelos estruturais por meio de ferramentas de modelagem molecular de duas enzimas da família GH43 de $P$. purpurogenum, uma bifuncional $\alpha$-1-arabinofuranosidase $/ \beta$-xilosidase e uma $\beta$ xilosidase, foram obtidas. Como outros membros da família, foi observado que os domínios catalíticos são constituídos por cinco lâminas de folhas- $\beta$ e o sítio ativo forma um funil (RAVANAL et al., 2013).

Modelos estruturais tridimensionais para HXYLA e HXYLB de H. grisea foram construídos usando como ferramenta o software online Phyre2 (http://www.sbg.bio.ic.ac.uk/ phyre2/html/page.cgi?id=index) que cria o modelo baseado em homologia com outras estruturas disponíveis no Protein Data Bank (PDB). A visualização, análise e edição do modelo construído foi realizado pelo software UCSF Chimera. Foi possível observar a presença das cinco lâminas de folhas- $\beta$ em ambas estruturas, o que está de acordo com as demais enzimas da família GH43 (Fig $18)$.

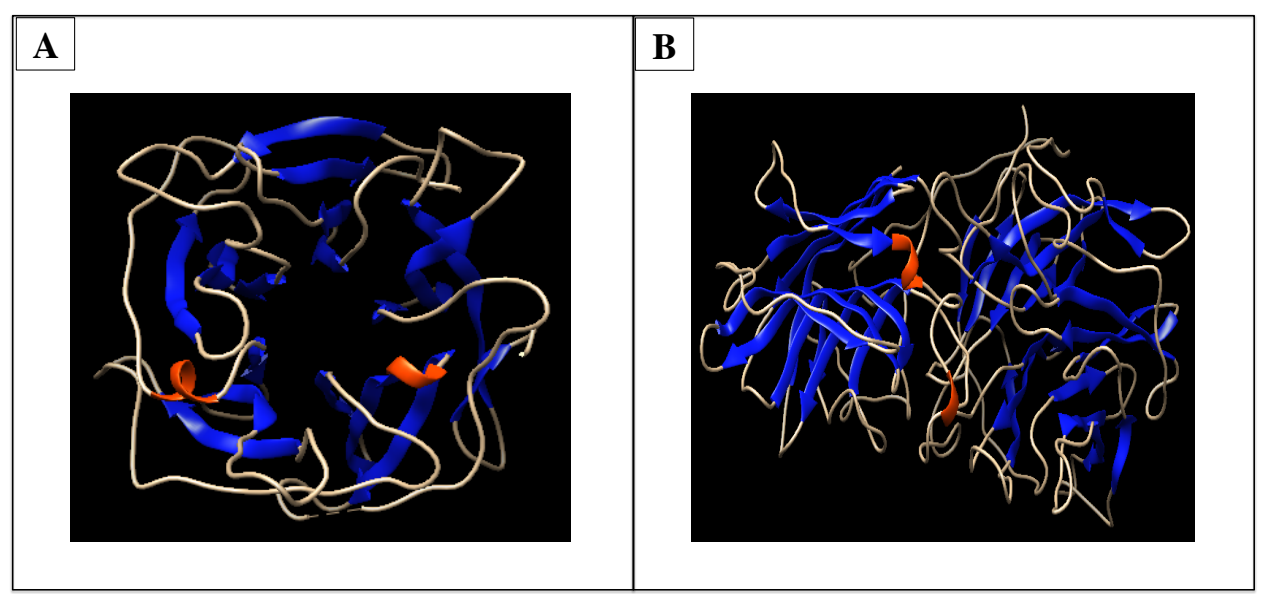

Figura 18 - Modelo tridimensional para HXYLA (A) e HXYLB (B) de H. grisea. Em azul, lâminas de folha- $\beta$ e em vermelho, $\alpha$-hélice. 


\subsection{3 - Expressão dos genes HxylA e HxylB por P. pastoris}

A levedura metilotrófica $P$. pastoris tem sido descrita como um sistema bem estabelecido para a produção de proteínas heterólogas, incluindo celulases e hemicelulases. Algumas XYLs fúngicas já foram produzidas com sucesso por $P$. pastoris como, por exemplo, de $N$. crassa (KIRIKYALI; CONNERTON, 2014) de $A$. niger ASKU28 (CHOENGPANYA et al., 2015) de Phanerochaete chrysosporium (HUY et al., 2013b) de H. insolens (FANG; XIA, 2015; YANG et al., 2014).

Com base no sucesso obtido na produção de XYLs por $P$. pastoris e com objetivo de alcançar altos níveis de produção das enzimas HXYLA e HXYLB procedeu-se a obtenção do cDNA das duas enzimas e transformação da levedura $P$. pastoris.

\subsubsection{1 - Obtenção do cDNA}

Os cDNAs de hxylA e hxylB foram obtidos seguindo o protocolo do item 5.15. Após o sequenciamento do DNA genômico e análise do perfil de restrição foi possível desenhar os oligonucleotídeos para amplificação do cDNA de $h x y l A$ e $h x y l B$ contendo sítios para clonagem nos vetores de expressão em P. pastoris (Tabela 8). Após a amplificação do cDNA a partir do RNA total do fungo $H$. grisea cultivado na presença de BCA e FT 2\%, o produto da PCR foi aplicado no gel de agarose $0,8 \%$ e a banda de aproximadante $984 \mathrm{pb}$ para o cDNA $h x y l A$ e $1617 \mathrm{pb}$ para o cDNA $h x y l B$ foi eluida do gel e utilizada para ligação no vetor de clonagem pGEM-T-Easy.

\subsubsection{2 - Clonagem no vetor PGEM-T-Easy}

Algumas etapas intermediárias foram necessárias para obter a construção final dos vetores de expressão destinados a transformação de P. pastoris. A subclonagem em pGEM-T-Easy foi uma estratégia utilizada para os insertos destinados aos vetores pPIC9 e pHILD2, para que fosse possível obter insertos com sítios de restrição adequados para a transferência do $\mathrm{cDNA} / h x y l A$ e cDNA/hxylB em fase de leitura correta nos vetores de expressão. Os plasmídeos contendo o cDNA pGEM/hxylA e pGEM/hxylB foram submetidos a sequenciamento para confirmar a sequência dos cDNAs. 


\subsubsection{3 - Clonagem do cDNA/hxylA e cDNA/hxylB nos vetores de expressão pHIL-D2 e pPIC9}

A expressão dos genes clonados nos vetores pHIL-D2 e pPIC9 é direcionada pelo promotor forte do gene AOX1. A proteína recombinante clonada no vetor pPIC9 é fusionada ao peptídeo sinal de secreção do fator- $\alpha$ de $S$. cerevisiae presente nesse vetor e pode ser secretada enquanto a secreção da proteína no vetor pHIL-D2 é alcançada pelo processamento do peptídeo sinal nativo (COS et al., 2006).

Para clonagem no vetor pHIL-D2 foi necessário digerir os plasmídeos pGEM/hxylA e pGEM/hxylB com a enzima de restrição EcoRI para liberação do inserto (cDNA), posteriormente o inserto foi purificado do gel de agarose e utilizado para ligação no vetor. O vetor pHILD2 apresenta apenas o sítio de EcoRI para clonagem, por esse motivo, o vetor foi previamente linearizado com EcoRI e defosforilado para evitar a recircularização, levando a construção dos vetores pHXYLA e pHXYLB.

Para clonagem no vetor de expressão pPIC9 os cDNAs foram amplificados com os oligonucleotídeos contendo os sítios de restrição para as enzimas EcoRI e NotI (Tabela 8). Os plasmídeos pGEM/hxylA e pGEM/hxylB gerados foram digeridos com as enzimas EcoRI e NotI e os fragmentos correspondentes aos cDNAs foram clonados no vetor pPIC9, previamente linearizado com as enzimas de restrição EcoRI e NotI, gerando os vetores pPXYLA e pPXYLB. As clonagens foram direcionadas para entrar em fase com o peptídeo sinal do fator- $\alpha$ de $S$. cerevisiae do vetor.

Os vetores pHXYLA, pHXYLB e pPXYLA, pPXYLB foram introduzidos em células da linhagem TOP10 de E. coli por eletroporação. Após a transformação, os clones foram analisados por PCR de colônia, onde foi possível obter a amplificação do fragmento correspondente ao do cDNA de hxylA (984 pb) e hxylB (1617 pb) em algumas das colônicas utilizadas como molde para a amplificação (Fig. 19). 


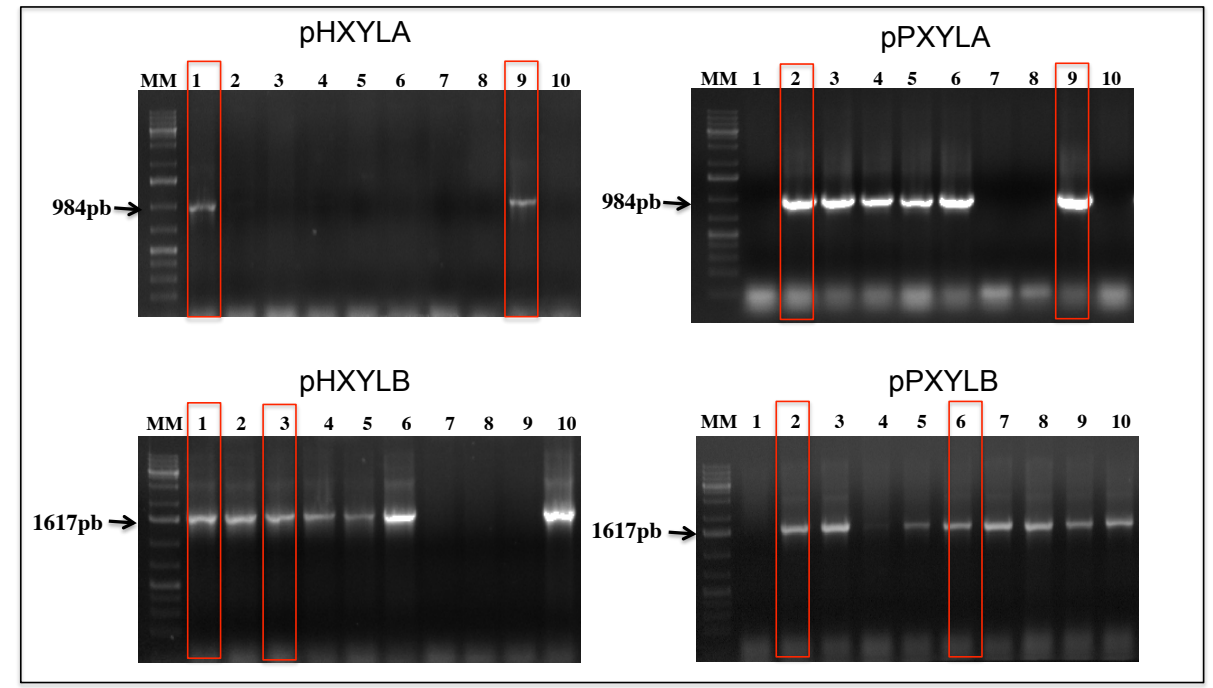

Figura 19 - Análise eletroforética em gel de agarose $0,8 \%$, corado com brometo de etídio, da PCR de colônia dos transformantes obtidos. Foram selecionadas 10 colônias de cada construção. Foi verificada a presença do inserto de $984 \mathrm{pb}$ para as construções contendo o cDNA hxylA (pHXYLA e pPXYLA) e de 1617 pb para as construções contendo o cDNA hxylB (pHXYLB e pPXYLB). Os clones selecionados (quadrado vermelho) foram submetidos a extração de DNA plasmidial. (MM) marcador molecular GeneRuler ${ }^{\mathrm{TM}} 1 \mathrm{~Kb}$ bp Plus DNA Ladder (Thermo Scientific).

Em seguida, foram selecionados aleatoriamente dois transformantes de cada construção (quadrado vermelho) para extração de DNA plasmidial para verificação da análise do perfil de restrição. A clivagem do DNA plasmidial liberou um fragmento de aproximadamente $984 \mathrm{pb}$ para construções com cDNA hxylA e 1617 pb para construções contendo o cDNA hxylB, conforme esperado (fig. 20).

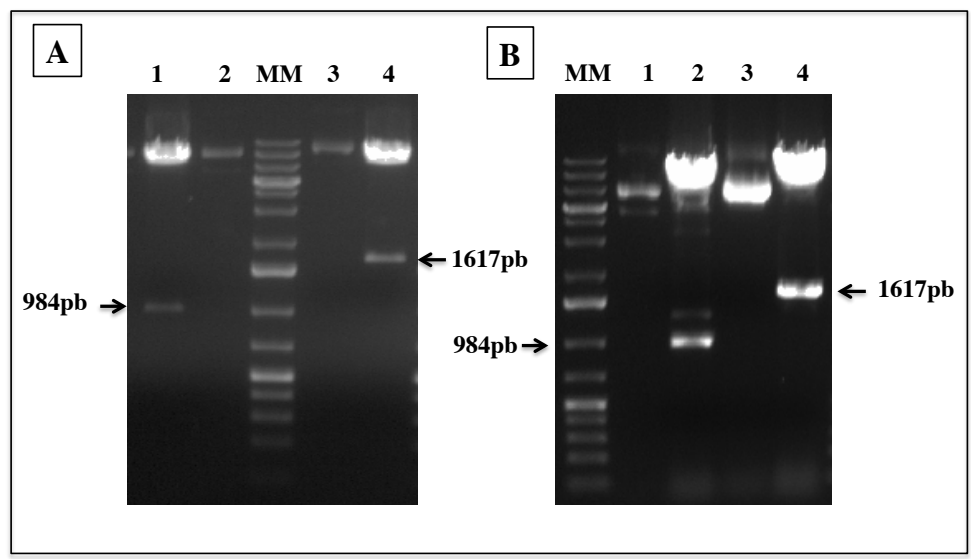

Figura 20 - Análise eletroforética em gel de agarose $0,8 \%$, corado com brometo de etídio, do produto da digestão dos vetores pHXYLA, pHXYLB, pPXYLA e pPXYLB. MM marcador molecular. (A) 1 - vetor pHXYLA digerido com a enzima EcoRI; 2 - vetor pHXYLA intacto; 3 - vetor pHXYLB intacto; 4 - vetor pHXYLB digerido com EcoRI. (B) 1 - vetor pPXYLA intacto; 2 - vetor pPXYLA digerido com as enzimas EcoRI e NotI; 3 - vetor pPXYLB intacto; 4 - vetor pPXYLB digerido com EcoRI e NotI. Foram liberados os fragmentos correspondentes ao cDNA $h x y l A$ e $h x y l B$ mostrando o sucesso da construção. 
Com o objetivo de confirmar a sequência do cDNA e verificar a orientação do inserto, o DNA plasmidial de dois clones de cada construção (pHXYLA, pHXYLB, pPXYLA e pPXYLB) foram submetidos a sequenciamento.

Foi verificado que apenas um dos dois plasmídeos de pHXYLA estava na orientação correta (in frame com o promotor AOX1) e enquanto nenhum dos dois plasmídeos de pHXYLB apresentaram a orientação correta. A partir desses resultados, foi escolhido o plasmídeo pHXYLA para seguir para transformação em P. pastoris. Em relação aos plasmídeos construídos a partir do vetor pPIC9 (pPXYLA e pPXYLB) submetidos ao sequenciamento foi observado que todos estavam na orientação correta.

Outra estratégia realizada foi a fusão dos cDNAs à sequência codante da cauda de 6-Histidina na extremidade N-terminal. Foram adicionados aos oligonucleotídeos sequencias de seis histidinas (his-tag) que permite a purificação de proteínas por cromatografia de afinidade. Os oligonucleotídeos contendo a his-tag estão listados na Tabela 8. Os oligonucleotídeos foram construídos para amplificação dos cDNAs $h x y l A$ e $h x y l B$ para inserção no vetor pPIC9. O cDNA do gene $h x y l A$ com cauda de histidina foi amplificado e seguiu para transformação em $P$. pastoris. Não foi possível a amplificação do cDNA de $h x y l B$ com cauda de histidina a partir dos oligonucleotídeos desenhados.

\subsubsection{4 - Transformação de P. pastoris}

Os vetores de expressão pHIL-D2 e pPIC9 são vetores integrativos e as contruções foram realizadas baseadas nos mecanismos pelos quais, normalmente, ocorrem a transformação e a integração no genoma de $P$. pastoris que podem ser por adição ou por substituição gênica (CEREGHINO; CREGG, 2000). Se a linearização do cassete de expressão ocorrer com a enzima BglII ou NotI (pPCI9 e pHIL-D2, respectivamente), a integração pode ser direcionada para a substituição do locus do gene AOX1 e se for realizada com a enzima SacI (tanto para pPIC9 quanto para pHIL-D2), a integração pode ocorrer por adição no locus do gene AOX1.

As construções foram realizadas na tentativa de se obter transformantes com diferentes capacidades de metabolizar o metanol. Para isso, após a confirmação da orientação correta dos insertos nos vetores pHIL-D2 e pPIC9 foram iniciados os procedimentos para transformação da levedura P. pastoris. Os transformantes de E. coli 
contendo os vetores pHXYLA, pPXYLA e pPXYLB foram submetidos à nova extração de DNA plasmidial em grande escala.

As células de $P$. pastoris foram transformadas com duas construções diferentes do vetor pHXYLA, duas do vetor pPXYLA e duas do vetor PPXYLB, bem como os controles pHIL-D2 e pPIC9, sem inserto (Fig. 21).

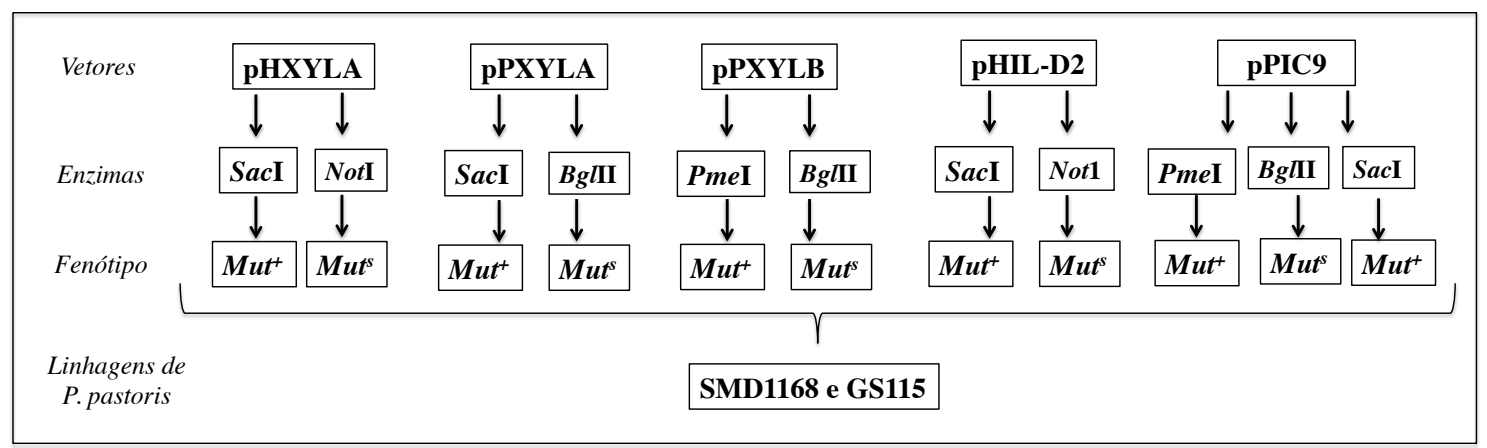

Figura 21 - Esquema para demonstração das estratégias utilizadas para linearizar os vetores para transformação de $P$. pastoris.

O vetor pHXYLA foi linearizado com a enzima de restrição SacI para liberação do cassete de expressão induzindo a obtenção do fenótipo $\mathrm{Mut}^{+}$e linearizado com a enzima de restrição Not I induzindo a obtenção do fenótipo Mut ${ }^{\mathrm{S}}$.

Após a linearização com as enzimas de restrição, o produto da digestão foi submetido a eletroforese em gel de agarose e posteriormente eluido. A digestão com SacI apenas lineariza o vetor (Fig. 22 B e C). No caso da digestão com NotI foram produzidos dois fragmentos, um de $6313 \mathrm{pb}$ e outro de $2880 \mathrm{pb}$. O que corresponde ao cassete de expressão e, portanto, o eluido do gel foi o de 6313 (Figura $22 \mathrm{~A} \mathrm{e} \mathrm{C).}$

O vetor pPXYLA foi linearizado com a enzima de restrição SacI e o vetor pPXYLB com a PmeI para liberação do cassete de expressão induzindo a obtenção do fenótipo $\mathrm{Mut}^{+}$(Fig. $23 \mathrm{~B}$ e C) e ambos vetores, pPXYLA e pPXYLB, foram linearizados com a enzima de restrição $B g l$ II induzindo a obtenção do fenótipo $\mathrm{Mut}^{\mathrm{S}}$ ( Fig. 23 A e C). 


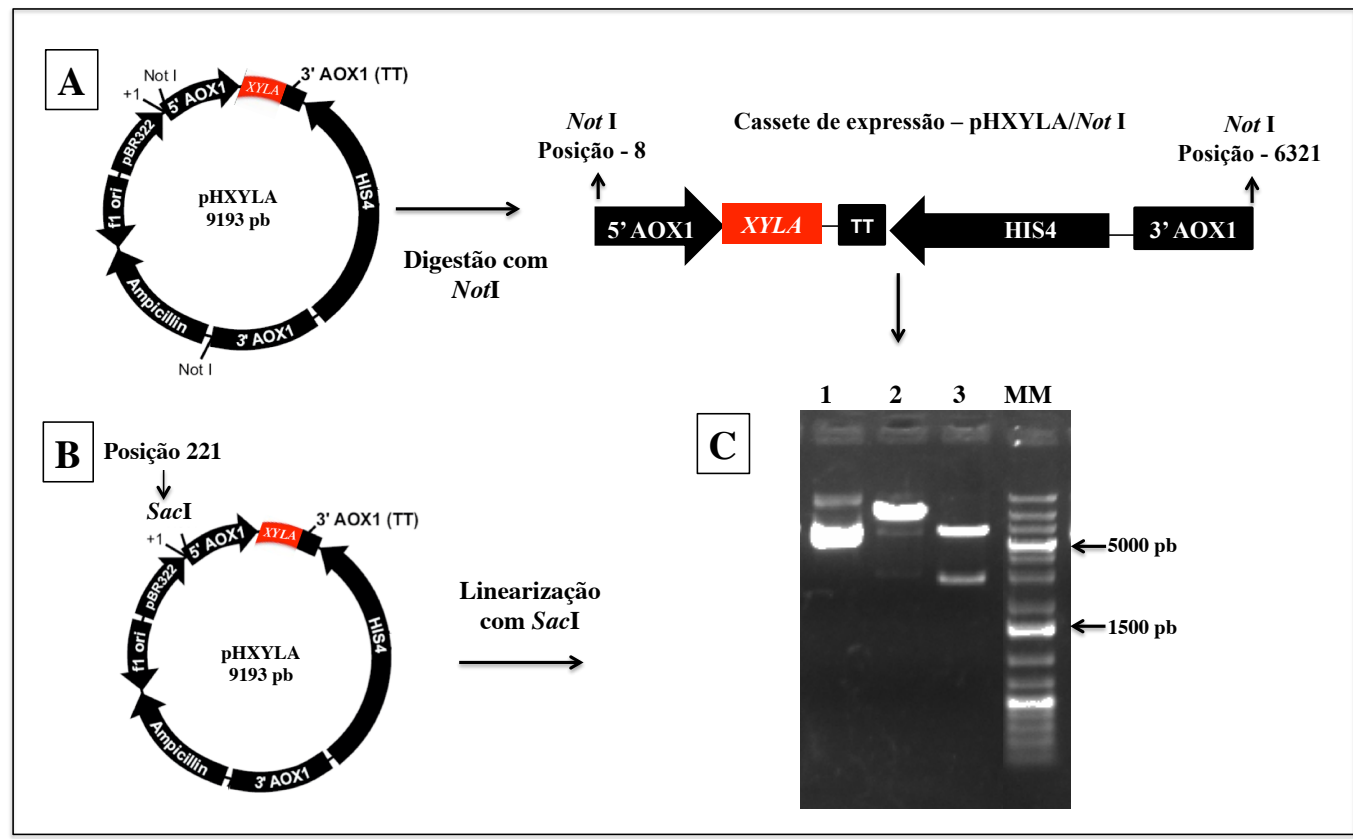

Figura 22 - Representação do vetor pHXYLA e sítios de restrição para linearização para liberação dos cassetes de expressão introduzidos na levedura $P$. pastoris. A: vetor pHXYLA e representação do cassete de expressão linearizado com NotI. B: vetor pHXYLA mostrando a posição de clivagem para linearização com a enzima SacI. C: Análise eletroforética dos produtos de clivagem com SacI (2) e NotI (3), além do vetor intacto (1).

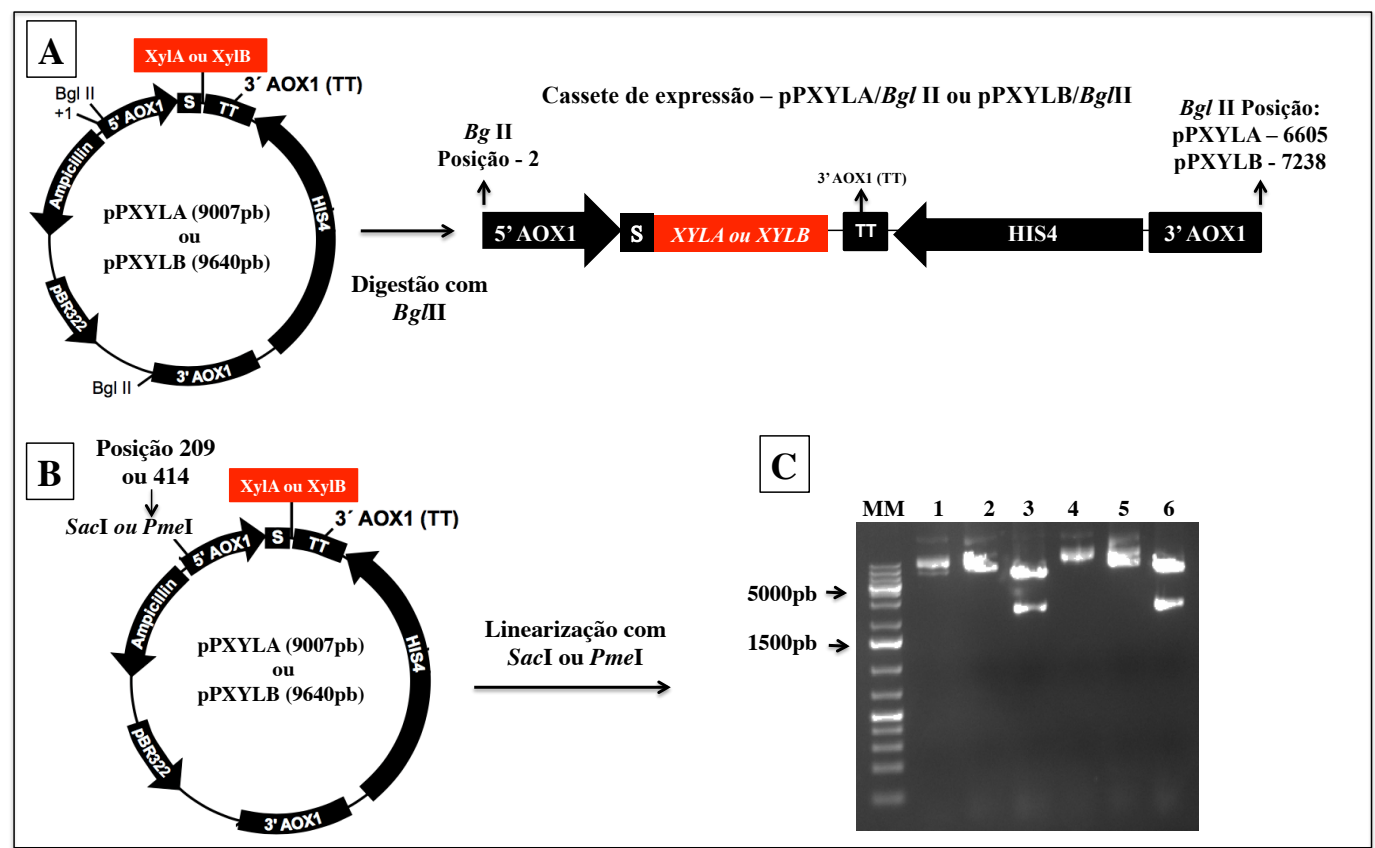

Figura 23 - Representação dos vetores, pPXYLA e pPXYLB, e sítios de restrição para linearização para liberação dos cassetes de expressão introduzidos na levedura $P$. pastoris. A: vetor pPXYLA e pPXYLB e representação do cassete de expressão linearizado com $B g l I I$. B: vetor pPXYLA e pPXYLB mostrando a posição de clivagem para linearização com a enzima SacI ou PmeI. C: Análise eletroforética em gel de agarose $0,8 \%$, corado com brometo de etídio, dos produtos de clivagem do vetor pPXYLA com SacI (2) e $B g l I I$ (3), além do vetor intacto (1) e do vetor pPXYLB digerido com PmeI (5) e BglII (6), além do vetor intacto (4). 
Além dos cassetes de expressão contendo o gene de interesse (cDNA hxylA e $h x y l B)$, os vetores vazios pHIL-D2 digerido com SacI e NotI e pPIC9 digerido com SacI, PmeI e BglII foram produzidos para transformação de P. pastoris sendo utilizados como controle negativo da produção das enzimas. Além desses, também foram produzidos cassetes de expressão contendo his-tag. Eles foram denominados de: pPXYLA/SacI/his, pPXYLA/BglII/his.

Após a linearização e precipitação, os cassetes foram introduzidos nas linhagens SMD1168 e GS115 da levedura P. pastoris por eletroporação. Os transformantes foram selecionados pela capacidade de crescer em meio seletivo sem histidina. Após 3 repiques em meio seletivo foram selecionadas cem colônias de cada construção.

\subsubsection{4 - Análise da produção de $\beta$-xilosidases por P. pastoris em placa Deep-weel}

Os transformantes foram analisados quanto à capacidade de produzir e secretar as XYLs recombinantes ativas (HXYLA e HXYLB). A seleção foi realizada após cultivo em meio BMMY para a indução da produção da proteína recombinante na presença de metanol, em placas do tipo Deep weel. Os sobrenadantes de cultura coletados foram analisados por atividade enzimática seguindo o protocolo descrito no item 5.4. Para seleção dos transformantes produtores das enzimas HXYLA e HXYLB foram analisadas 12 placas deep well, contendo noventa e cinco (95) transformantes de cada construção e 1 transformante de cada controle, no total de 1.140 transformantes analisados, conforme o esquema da figura 24.

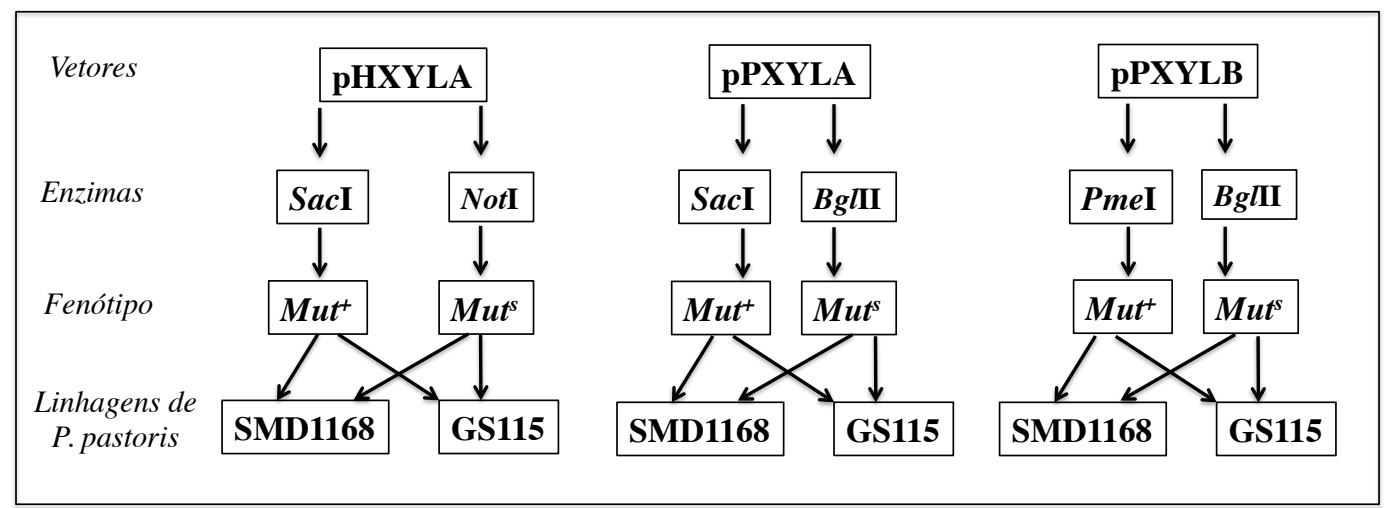

Figura 24 - Esquema para demonstração dos transformantes $\mathrm{Mut}^{+}$e $\mathrm{Mut}^{\mathrm{S}}$ para serem analisados em placa do tipo Deep Well.

Além dos transformantes já mencionados, foram analisados os que foram obtidos com vetor contendo his-tag. O cassete de expressão pPXYLA/Mut ${ }^{+} / h i s$ também foi introduzido nas linhagens SMD1168 e GS115. Para seleção dos transformantes 
produtores da HXYLA foram analisadas 4 placas deep well, no total de 380 transformantes analisados. Os transformantes de $\mathrm{pPXYLA} /$ his não apresentaram atividade enzimática no sobrenadante de cultura, mesmo assim, foram selecionados 5 transformantes de cada construção para análise da produção em maior escala.

Para as construções com o cassete de expressão pHXYLA, foram obtidos transformantes com atividade de $\beta$-xilosidase dos dois fenótipos e nas duas linhagens. Em relação ao cassete de expressão pPXYLA e pPXYLB só foi possível detecção de transformantes capazes de secretar a enzima ativa nas construções utilizando a linhagem SMD1168.

Os transformantes apresentaram níveis variados de atividade enzimática. Essa variação na atividade deve-se ao fato da utilização de vetores integrativos para transformação em $P$. pastoris e a possibilidade de ocorrência de vários eventos de recombinação que podem variar o nível de expressão do gene (CEREGHINO; CREGG, 2000).

\subsubsection{4 - Análise da produção das proteínas HXYLA e HXYLB em frasco pela levedura P. pastoris}

Após à análise inicial dos transformantes produtores de XYLs em placa do tipo deep well, foram selecionados alguns transformantes que apresentaram maior atividade para produção em frasco (conforme item 5.23).

\subsubsection{1 - Produção de HXYLA e HXYLB pelos transformantes das} construções com o vetor pPIC9

Foram selecionados vinte transformantes de cada construção: pPXYLA/SMD1168/Mut ${ }^{+}\left(\mathrm{pPXYLA} / \mathrm{SM}^{+}\right), \mathrm{pPXYLB} \mathrm{SMD} 1168 / \mathrm{Mut}^{+}\left(\mathrm{pPXYLB} / \mathrm{SM}^{+}\right)$, pPXYLA/SMD1168/Mut ${ }^{\mathrm{s}}\left(\mathrm{pPXYLA} / \mathrm{SM}^{\mathrm{S}}\right.$ ), pPXYLB/SMD1168/Mut ${ }^{\mathrm{S}}\left(\mathrm{pPXYLB} / \mathrm{SM}^{\mathrm{S}}\right)$. Os transformantes selecionados, bem como os controles negativos, foram cultivados em meio de indução BMMY-U contendo $1 \%$ de metanol e as alíquotas do sobrenadante coletadas após diferentes tempos $(24,48,72$ e 96 h) foram analisadas quanto a atividade enzimática, integração no genoma e quanto ao perfil das proteínas secretadas em SDSPAGE.

As maiores atividades foram obtidas com os transformantes que continham os cassetes de expressão direcionados para obtenção de fenótipo $\mathrm{Mut}^{+}$e, por isso, optou-se 
por trabalhar com os dois melhores produtores da construção pPXYLA/SM ${ }^{+}$, denominado de pPXYLA/SM $/ 40$ e da pPXYLB/SM ${ }^{+}$, denominado pPXYLB/SM ${ }^{+} / 15$.

Para confirmar a integração no genoma da levedura, foi realizada PCR de colônia por se tratar de um método de screening rápido e simples (AKADA; MURAKANE; NISHIZAWA, 2000) com os transformantes pPXYLA/SM ${ }^{+} / 40$ e pPXYLB/SM+15, bem como a levedura transformada apenas com o vetor pPIC9.

Para as amplificações foram utilizados os oligonucleotídeos AOX5 e AOX3 (Tabela 8). O produto da amplificação do vetor pPCI9 vazio corresponde a um fragmento de $492 \mathrm{pb}$. Como o cDNA da HXYLA tem $984 \mathrm{pb}$ o produto esperado para o pPXYLA é de 1476 pb $(492+984=1476)$ e o produto esperado para o cassete de expressão pPXYLB é de 2109 pb $(492+1617=2109)$. Foram utilizados como controle positivo o DNA plasmidial pPXYLA e pPXYLB e como controle negativo o vetor pPIC9. Além disso, foram utilizados os oligonucleotídeos específicos (Tabela 7). Foi possível observar a presença do amplicom correspondente aos cDNAs, hxynA e hxynB, no genoma da levedura acrescido do tamanho correspondente ao amplicom do promotor AOX1 (Fig. 25).

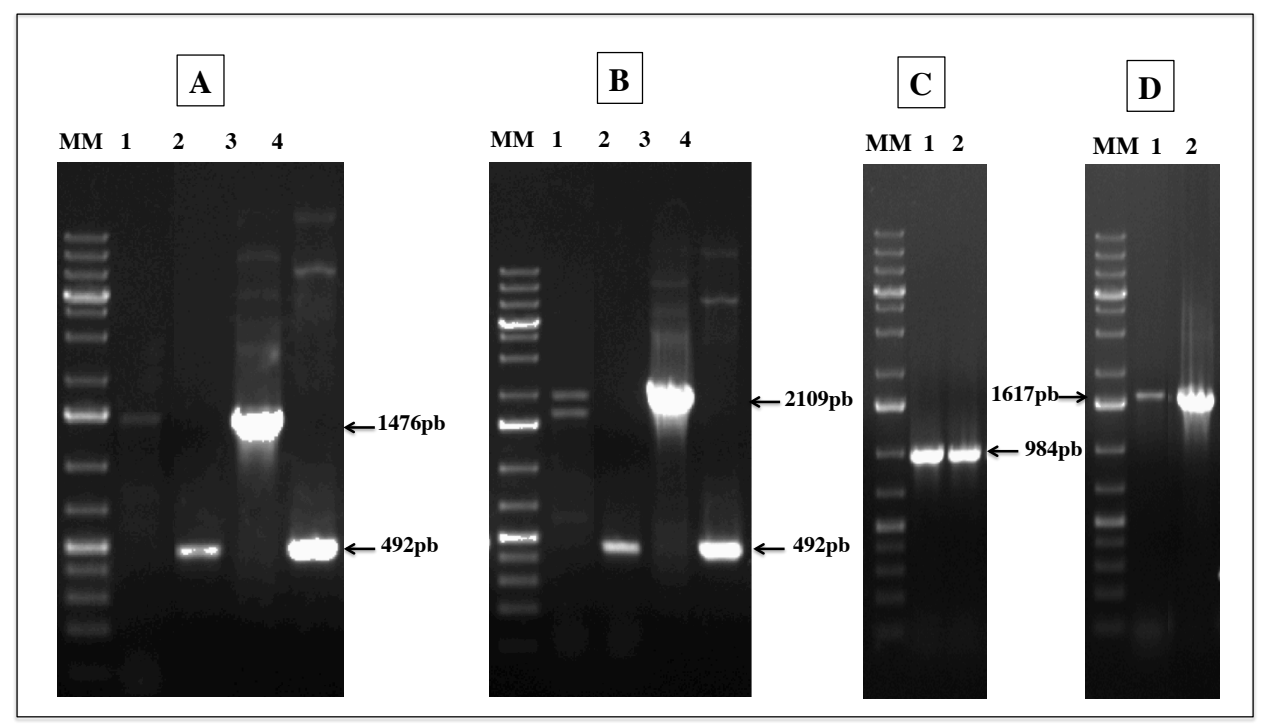

Figura 25 - Análise eletroforética em gel de agarose $0,8 \%$, corado com brometo de etídio, dos produtos da amplificação obtidos por PCR de colônia de leveduras dos transformantes pPXYLA/SM $/ 40$ e pPXYLB/SM $\mathbf{S M}^{+} / \mathbf{1 5}$. A: PCR de colônia utilizando os oligonucleotídeos AOX5 e AOX3; 1- pPXYLA/SM ${ }^{+} / 40 ; 2$ - Controle (P.pastoris transformada apenas com vetor pPIC9 linearizado com SacI); 3 e 4 - Controles positivos. B: PCR de colônia utilizando os oligonucleotídeos AOX5 e AOX3; 1 - pPXYLB/SM $/ 15 ; 2$ - Controle (P. pastoris transformada apenas com vetor linearizado com PmeI); 3 e 4 - Controles positivos. C: PCR de colônia utilizando os oligonucleotídeos específicos; 1 - pPXYLA/SM ${ }^{+} / 40 ; 2$ - Controle positivo. D: PCR de colônia utilizando os oligonucleotídeos específicos; 1 - pPXYLB/SM ${ }^{+} / 15$; 2 - Controle positivo. 
Após a confirmação da integração, foi avaliada a produção das enzimas HXYLA e HXYLB por $P$. pastoris em frasco. Os transformantes $\mathrm{pPXYLA} / \mathrm{SM}^{+} / 40$ e pPXYLB/ $\mathrm{SM}^{+} / 15$, bem como os controles negativos de $P$. pastoris, foram cultivados em meio de indução BMMY-U contendo $1 \%$ de metanol como fonte de carbono e as alíquotas do sobrenadante foram coletadas a cada $24 \mathrm{~h}$ e analisadas quanto a atividade enzimática e perfil de proteínas em SDS-PAGE.

Após $96 \mathrm{~h}$ de cultivo o sobrenadante de cultura do transformante pPXYLA/SM $/ 40$ apresentou atividade de 0,49 U/mL $\pm 0,005$ (Fig. 26). Em relação ao transformante pPXYLB/SM+15, foi detectada a atividade após $96 \mathrm{~h}$ de $0,5 \mathrm{U} / \mathrm{mL} \pm$ 0,005. Os controles, mesmo sem o cassete de expressão contendo $h x y l A$ ou $h x y l B$ no genoma, também apresentaram atividade de $\beta$-xilosidase, apesar de apresentarem atividade mais baixa que a obtida pelos transformantes (Fig. 26).

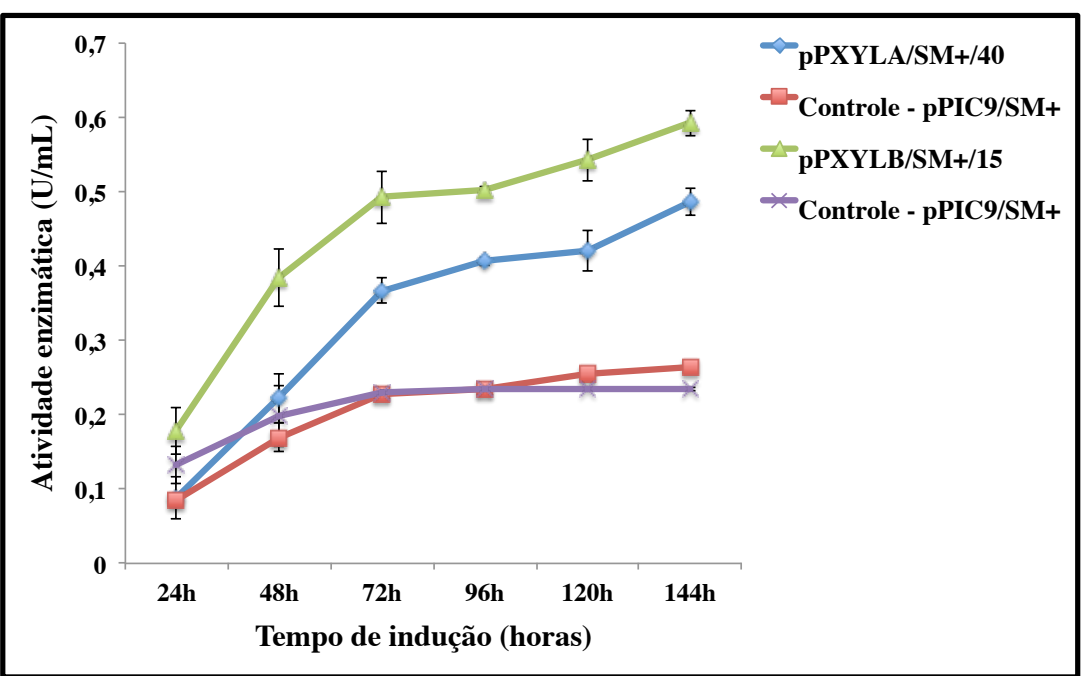

Figura 26 - Cinética da produção de HXYLA e HXYLB por $P$. pastoris por $144 \mathrm{~h}$ de indução na presença de $1 \%$ de metanol. Além dos transformantes $\mathrm{pPXYLA} / \mathrm{SM}^{+} / 40$ e $\mathrm{pPXYLB} / \mathrm{SM}^{+} / 15$, foram analisadas as atividades obtidas com o sobrenadante dos controles negativos (transformados apenas com o vetor pPIC9 vazio).

Esse fato já foi relatado durante a produção de uma $\beta$-glicosidase (BGLU44) da família GH 1 de Arabidopsis thaliana por P. pastoris, onde foi obtido atividade com os sobrenadantes de cultura dos transformantes obtidos com o vetor vazio. Além disso, foi relatado que o processo de purificação da BGLU44 foi dificultado pela secreção de $\beta$ glicosidases endógenas que hidrolisam substratos rotineiramente utilizados em ensaios enzimáticos (por exemplo, PNPG) (XU et al., 2004). Posteriormente, em trabalho realizado pelo mesmo grupo e na tentativa de identificar a proteína endógena secretada 
por $P$. pastoris, foi identificada uma exo- $\beta-(1,3)$-glucanase $(\mathrm{EXG} 1)$, pertencente à família GH 5. Essa enzima foi purificada após o cultivo das células de P.pastoris X-33 transformadas com o vector $\mathrm{pPICZ} \alpha \mathrm{B}$ vazio. A enzima purificada, apresentou massa molecular de $47 \mathrm{kDa}$ e foi capaz de hidrolisar os substratos pNPG (100\%) e pNPX (31\%) e MUG (4-metil-umbeliferil- $\beta$-D-glucoronídeo) (XU; SHIH; POULTON, 2006).

O perfil de proteínas secretadas tanto pelo controle quanto pelos transformantes foi analisado em gel SDS-PAGE (Fig. 27 A e B). Não foi detectada diferença visível entre o perfil dos transformantes e do controle negativo, ambos analisados por $144 \mathrm{~h}$.

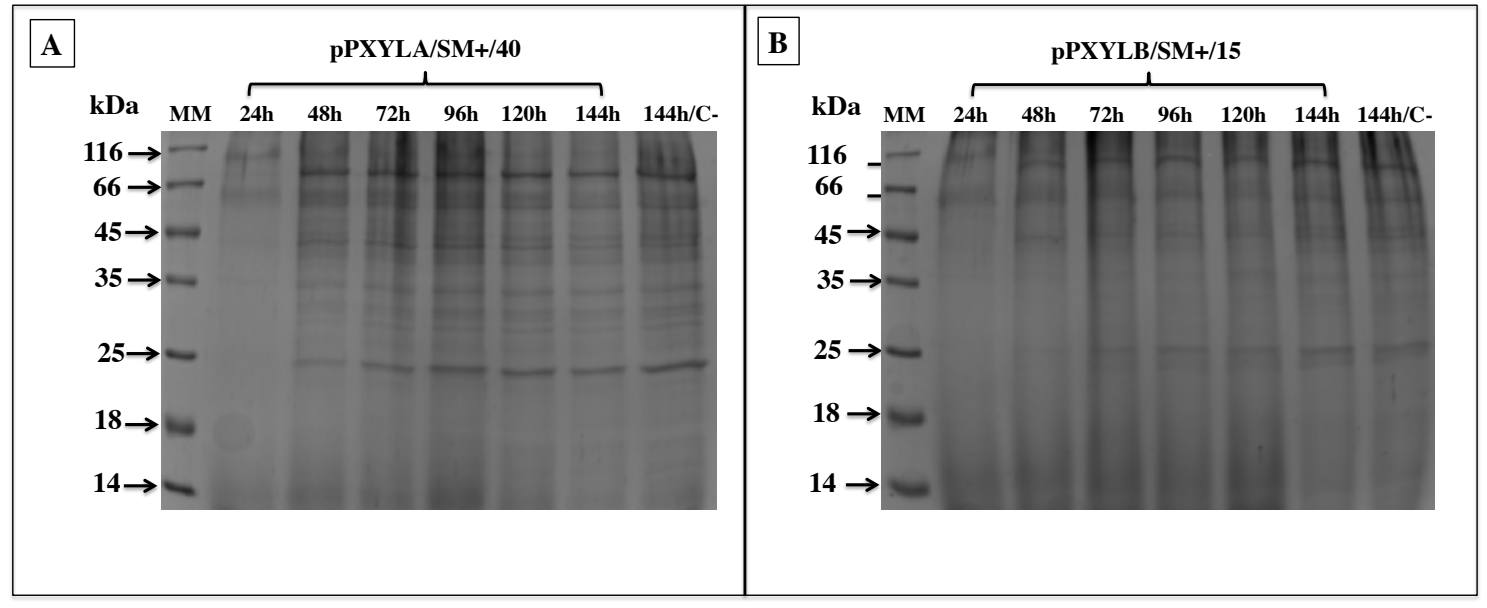

Figura 27 - Análise do perfil de proteínas secretadas pelos transformantes pPXYLA e pPXYLB em SDS-PAGE 13\% corado por Azul de Comassie. (MM) - Marcador de Massa Molecular, Unstained Protein Molecular Weight Marker (Fermentas). A: Perfil das proteínas secretadas pelo transformante pPXYLA/SM+/40 por $144 \mathrm{~h}$ de indução com metanol $1 \%$ e controle negativo pPIC9/SM induzido por $144 \mathrm{~h}$. B: Perfil das proteínas secretadas pelo transformante pPXYLB/SM+/15 por $144 \mathrm{~h}$ de indução com metanol $1 \%$ e controle negativo pPIC9/SM induzido por $144 \mathrm{~h}$. Todas as amostras foram precipitadas com TCA.

A atividade de $\beta$-xilosidase também foi determinada utilizando-se MUX como substrato. Após à análise da liberação de 4-metilumbeliferil após exposição da microplaca a luz UV, foi possível observar que os sobrenadantes de cultura dos transformantes $\mathrm{pPXYLA} / \mathrm{SM}^{+} / 40$ e $\mathrm{pPXYLB} / \mathrm{SM}^{+} / 15$ apresentaram capacidade de hidrolisar o substrato, liberando o produto de 4-metilumbeliferil (Fig. 28 B). Esse substrato também foi utilizado para a determinação da atividade enzimática por zimograma e o resultado está apresentado na figura $28 \mathrm{C}$. Foi possível detectar a presença de duas bandas com atividade entre 50 e $80 \mathrm{kDa}$, tanto nos controles como nos transformantes. 


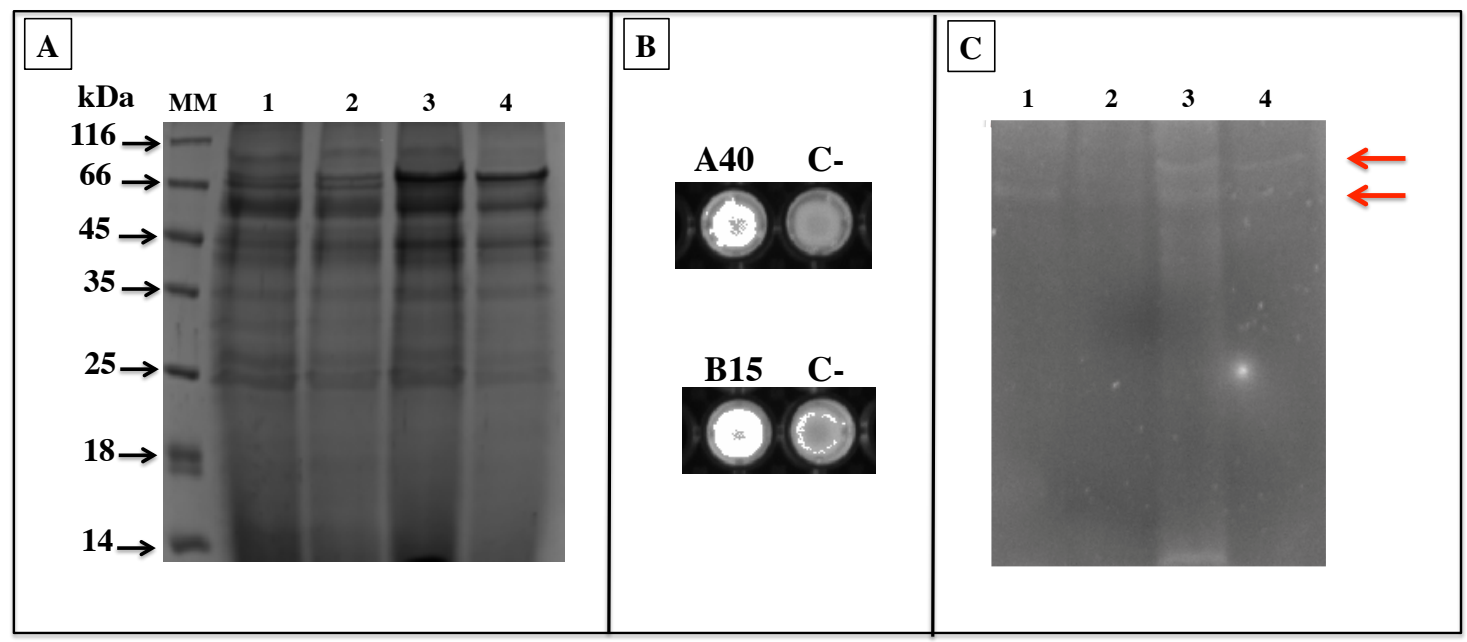

Figura 28 - Perfil de proteínas secretadas pelo transformante pPXYLA/SM ${ }^{+} / 40$ e pPXYLB/SM $/$ 15. A: Perfil poteico do $\mathrm{pPXYLA} / \mathrm{SM}^{+} / 40$ (linha 1) e $\mathrm{pPXYLB} / \mathrm{SM}^{+} / 15$ (linha 3 ) e dos controles negativos (Linha 2 e 4) concentrado por ultrafiltração (20 vezes). B: Dosagem de atividade utilizando o MUX como substrato para os transformantes (A40 e B15) e o controles negativos. C: Zimograma do sobrenadante de cultura de $\mathrm{pPXYLA} / \mathrm{SM}^{+} / 40$ (linha 1) e $\mathrm{pPXYLB} / \mathrm{SM}^{+} / 15$ (linha 3 ) e dos controles negativos (Linha 2 e 4). Seta vermelha indica as duas bandas que mostraram atividade de $\beta$-xilosidase.

Com base nesses resultados, não foi possível determinar a banda com atividade de $\beta$-xilosidase por esses transformantes. Novos ensaios de otimização do zimograma são requeridos, bem como, a realização da otimização da produção dessas enzimas ou ainda a produção utilizando outras estratégias como, por exemplo, emprego de novos vetores. A enzima HXYLA foi produzida pelos transformantes resultantes da construção com o vetor pHIL-D2 e os resultados são apresentados a seguir.

\subsubsection{2 - Produção de HXYLA pelos transformantes das construções com o vetor pHIL-D2}

O cassete de expressão pHXYLA foi linearizado com as enzimas, SacI e NotI, para obtenção dos seguintes transformantes: pHXYLA/SMD1168/Mut ${ }^{+}$

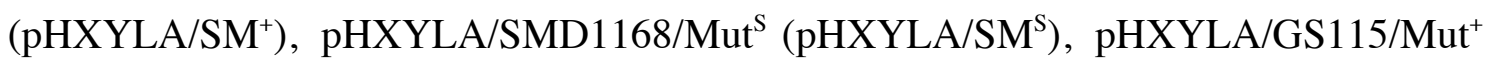
$\left(\mathrm{pHXYLA} / \mathrm{GM}^{+}\right) ; \quad$ pHXYLA/GS115/Mut ${ }^{\mathrm{s}} \quad\left(\mathrm{pHXYLA} / \mathrm{GM}^{\mathrm{s}}\right)$. O fenótipo dos transformantes foi analisado segundo estabelecido pelo manual "Pichia expression Kit K1710-01 - Invitrogen" e por PCR de colônia (pela amplificação da banda de 2,2 kb correspondente ao gene aoxl). Foram analisados 15 transformantes de cada uma das quatro construções. 
O resultado dos cinco produtores de HXYLA que obtiveram maior atividade com as construções usando o vetor pHIL-D2 estão apresentados na figura 29. Os resultados representam a atividade enzimática detectada no sobrenadante de cultura após 96 h de indução na presença de $1 \%$ de metanol.

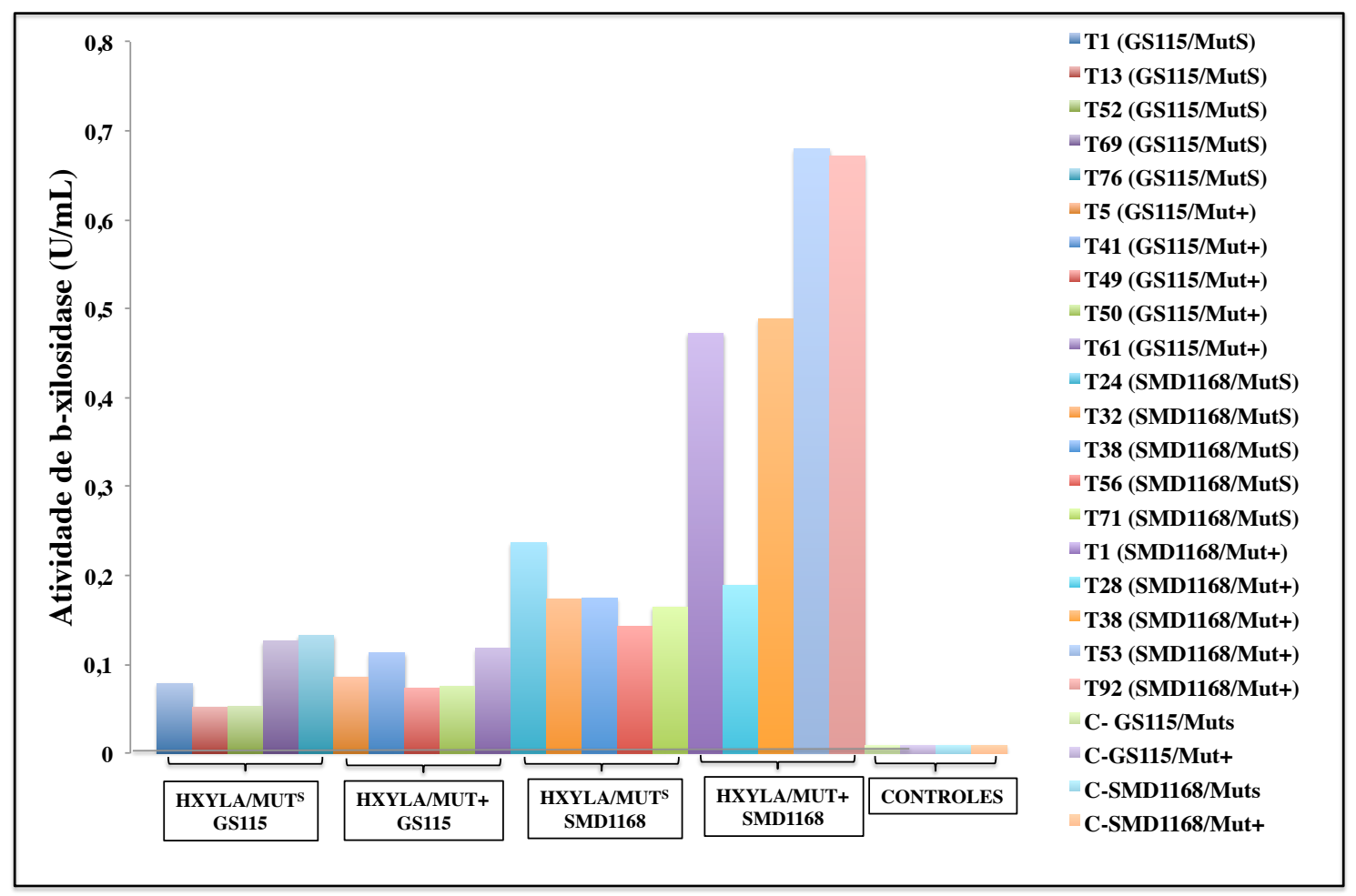

Figura 29 - Atividade enzimática de $\beta$-xilosidase obtida pelos transformantes produtores de HXYLA. Os resultados representam os valores de atividade de 5 transformantes de cada construção: pHXYLA/GM ${ }^{\mathrm{S}}$ (T1, T13, T52, T69, T76); pHXYLA/GM+ (T5, T41, T49, T50, T61); pHXYLA/SM ${ }^{\mathrm{S}}$ (T24, T32, T38, T56, T71) e pHXYLA/SM+ ${ }^{+}$(T1, T28, T38, T53, T92). Além dos controles negativos: pHIL-D2/GM ; pHIL-D2/GM+; ${ }^{+}$HIL-D2/SM ${ }^{+}$. Os valores representam a média e o desvio de três dosagens diferentes realizadas com o sobrenadante de cultura de $P$. pastoris no ponto de $96 \mathrm{~h}$.

Os transformantes que apresentaram maior atividade enzimática foram o da construção $\mathrm{pHXYLA} / \mathrm{SM}^{+}$e por isso, para esses transformantes, foi realizada a cinética da produção em frasco por 96 h de indução (Fig 30). Diferente do ocorrido com os transformantes das construções com o vetor pPIC9, não foi detectada atividade no sobrenadante do controle (transformado apenas com o vetor pHIL-D2).

O aumento nos níveis de produção da enzima HXYLA pela linhagem SMD1168 comparado com a linhagem GS115, provavelmente, deve-se ao fato da SMD1168 ser deficiente na produção e secreção de proteases que podem degradar a enzima recombinante. Muitas vezes, se faz necessário testar mais de uma linhagem para produção de uma mesma proteína (SPOHNER et al., 2015). Para a proteína CD81 
humana, a maior produção foi obtida com a linhagem selvagem de X33 em comparação com a linagem GS115 (JAMSHAD et al., 2008). Similar ao obtido em nosso trabalho, a linhagem SMD1168 foi melhor produtora para uma acetil xilana esterase 2 (Pcsx2) de $P$. chrysosporium do que comparado com outras linagens de P. pastoris como X33 e GS115 (HUY et al., 2013a). Já para uma endo-1,4-xilanase de Bacillus pumilus HB030 produzida por $P$. pastoris GS115 e SMD1168, a maior atividade obtida foi com um transformante obtido pela linhagem GS115 (JIANG; SONG; MA, 2003).

Normalmente, transformantes $\mathrm{Mut}^{+}$são caracterizados por apresentarem uma taxa de crescimento superior à dos transformantes $\mathrm{Mut}^{\mathrm{S}}$ quando cultivado em meio contendo metanol como única fonte de carbono, apresentando produtividade superior (LOOSER et al., 2015). No entanto, os transformantes Mut ${ }^{+}$são muito sensíveis a altas concentrações de metanol, tornando o aumento da escala de produção mais difíceis (KRAINER et al., 2012).

Após a seleção dos melhores transformantes produtores de HXYLA, foi realizada a cinética ( 0 a 96 h) dos transformantes pela linhagem SMD1168. A maior atividade foi obtida pelo transformante de número $92(0,67 \mathrm{U} / \mathrm{mL} \pm 0,02)$ e pelo transformante $53(0,67 \mathrm{U} / \mathrm{mL} \pm 0,03)$ após $96 \mathrm{~h}$ de cultivo em meio contendo $1 \%$ metanol (Fig. 30).

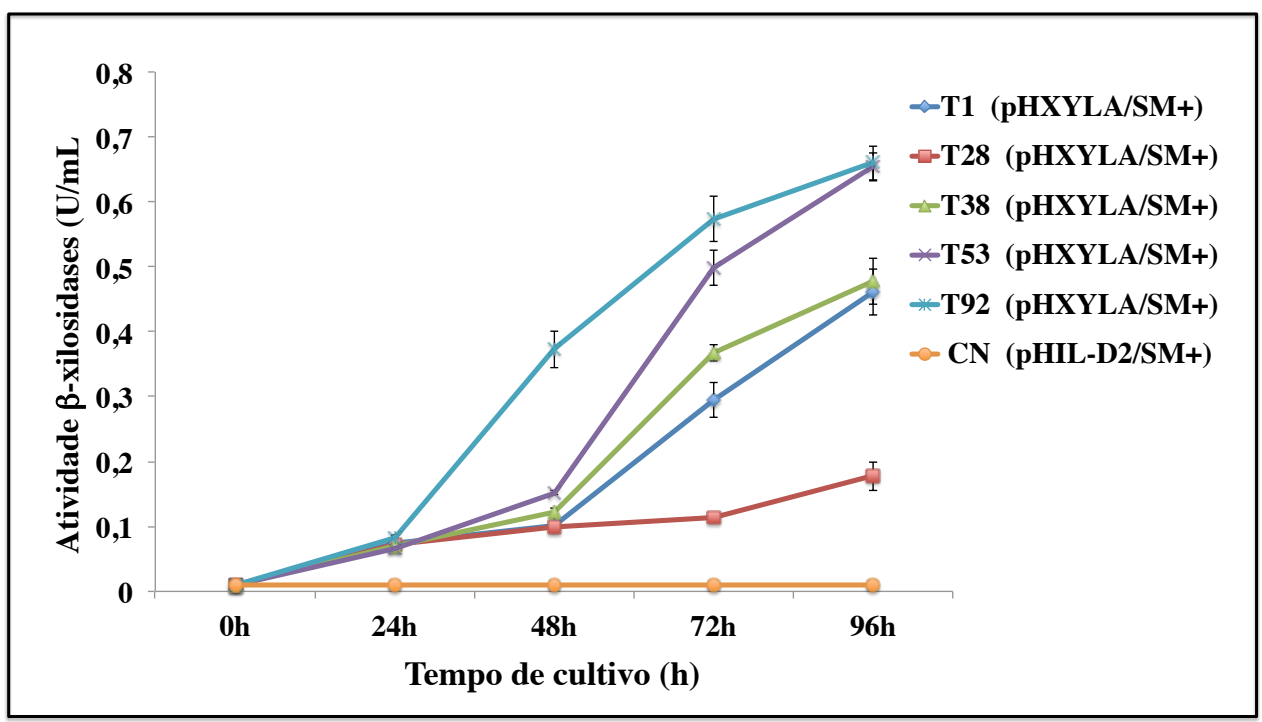

Figura 30 - Cinética de produção de HXYLA por 96 h de cultivo pelos transformantes T1, T28, T38, T53 e T92, além do controle negativo (CN-pHIL-D2/SM+). O valor de cada ponto representa a média e o desvio padrão de três dosagens utilizando o pNPX como substrato. 
A enzima HXYLA de $H$. grisea foi secretada por $P$. pastoris mesmo sem a presença do peptídeo sinal característico na proteína ou no vetor. Utilizando a ferramenta online SecretomeP 2.0 Server, foi possível predizer que as duas $\beta$ xilosidases de $H$. grisea podem ser secretadas por vias de secreção não clássicas .

Similar aos resultados obtidos no presente trabalho, duas $\beta$-xilosidases de $H$. insolens, Xyl43A e Xyl43B, foram produzidas com sucesso por E. coli e as atividades das frações celulares e extracelulares foram comparadas. A maior parte da atividade foi encontrada nas frações extracelulares de Xyl43A (> 90\%) e nas frações intracelulares de Xyl43B (> 80\%) (YANG et al., 2014). O mesmo foi relatado para $\beta$-xilosidases dos fungos termofílicos Paecilomyces thermophila (PtXyl43) e Thermomyces lanuginosus (TlXyl43) que foram secretadas por E. coli mesmo não apresentando peptídeo sinal em suas sequências (CHEN et al., 2012; TENG et al., 2011).

Para verificar o perfil de proteínas secretadas pelo transformante 92, foi realizado uma análise por meio de um gel SDS-PAGE onde foi possível observar a presença de uma banda proteíca de aproximadamente $37 \mathrm{kDa}$ que corresponde ao tamanho predito para a enzima HXYLA (Fig. 31).

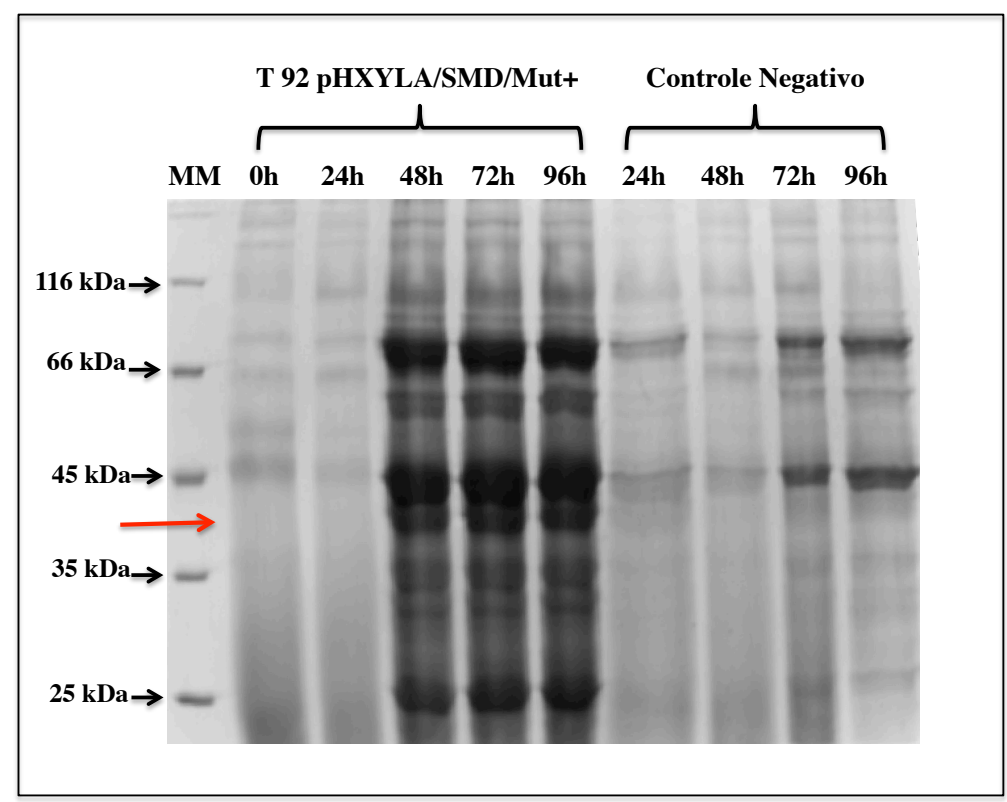

Figura 31 - Análise do perfil de proteínas secretadas pelo transformante T92 em gel de poliacrilamida $13 \%$ corado por Azul de comassie. MM - marcador molecular; Sobrenadante de cultura do transformante T92 precipitado por TCA (item 4.12) nos tempos de cultivo de $0 \mathrm{~h}$ (sobrenadante de cultura do transformante cultivado em meio com glicerol), 24, 48, 72 e $96 \mathrm{~h}$; além do controle (SMD1168 transformada apenas com o vetor pHILD2) de 24 a $96 \mathrm{~h}$. A seta vermelha mostra a posição da banda de aproximadamente $37 \mathrm{kDa}$ correspondente ao tamanho predito para HXYLA. 


\subsubsection{5 - Otimização da produção de HXYLA por P. pastoris por meio de planejamento experimental.}

A redução dos custos na produção de enzimas comerciais através da otimização da fermentação é um princípio básico para aplicações industriais (SPOHNER et al., 2015). Várias estratégias podem ser utilizadas para melhorar a produção de proteínas por $P$. pastoris como, por exemplo, modificar os parâmetros da fermentação $(\mathrm{pH}$, temperatura e taxa de crescimento), alterar a composição do meio (enriquecer o meio, adicionar casaminoácidos ou peptona) e reduzir a concentração de sal (AHMAD et al., 2014).

Essa otimização do meio de cultura, normalmente, é realizada variando um fator e mantendo os outros fatores a um nível constante. Este técnica é demorada e incapaz de detectar as interações entre fatores. Uma das técnicas mais úteis para identificar significância dos fatores e encontrar condições ideais são estatisticamente baseadas em desenhos experimentais, tais como o planejamento fatorial $2^{3}$ (DAMASO et al., 2003).

Com o objetivo de otimizar a produção de HXYLA por $P$. pastoris foi proposto um delineamento composto central rotacional (DCCR). A produção da enzima HXYLA pelo transformante 92 (SMD1168/Mut ${ }^{+}$) foi analisada e a cada $24 \mathrm{~h}$ foram coletadas alíquotas para análise de atividade e determinação da $\mathrm{OD}_{600}$. Os parâmetros analisados foram a densidade celular inicial, concentração de fonte de carbono (metanol) e fonte de nitrogênio (extrato de levedura e uréia). O resultado da atividade enzimática relacionado com as variações dos parâmetros está apresentado na Tabela 17.

A presença de metanol é essencial na realização da transcrição e sua concentração afeta consideravelmente a produção de proteínas heteróloas por $P$. pastoris. Dependendo da proteína heteróloga, a concentração ótima de metanol pode variar num intervalo de $0,1 \%$ a 3,0\% final (MINJIE; ZHONGPING, 2013). Já o nitrogênio é um dos micronutrientes essenciais para fermentação em $P$. pastoris, a fonte de nitrogênio é fornecida, normalmente, por meio da adição de hidróxido de amônio, que também tem efeito sobre o controle do pH para o nível desejado (COS et al., 2006). O aumento das concentrações de amônio no meio de cultura pode prolongar a fase lag e, assim, inibir o crescimento de células e, consequentemente, a produção de proteínas (YANG; ZHOU; ZHANG, 2004).

Em testes realizados por Carvalho (2008) foi observado que o meio de cultura contendo peptona, extrato de levedura e uréia foi melhor para produção da HXYN2 recombinante do que comparado com a fonte de nitrogênio, normalmente, utilizada para 
P. pastoris, o YNB (Yeast Nitrogen Base). Por isso, optou-se por trabalhar com essas fontes de nitrogênio orgânico (peptona e extrato de levedura) e inorgânico (Uréia). Para a composição do meio foi utilizada a proporção de uréia e extrato de levedura de $1,34: 1,00 \%(\mathrm{p} / \mathrm{v})$.

Tabela 17 -Efeito da composição do meio de cultura para a produção de HXYLA por $P$. pastoris.

\begin{tabular}{ccccc}
\hline Ensaios & Metanol* $^{*}$ & $\begin{array}{c}\text { Fonte de } \\
\text { nitrogênio** }\end{array}$ & OD $_{\mathbf{6 0 0}}$ inicial & $\begin{array}{c}\text { Atividade HXYLA } \\
\mathbf{9 6} \mathbf{h}(\mathbf{U} / \mathbf{m L})\end{array}$ \\
\hline 1 & 0,6 & 1,4 & 3 & 0,095 \\
2 & 1,7 & 1,4 & 3 & 0,901 \\
3 & 0,6 & 3,5 & 3 & 0,159 \\
4 & 1,7 & 3,5 & 3 & 0,237 \\
5 & 0,6 & 1,4 & 8,5 & 0,056 \\
6 & 1,7 & 1,4 & 8,5 & 1,060 \\
7 & 0,6 & 3,5 & 8,5 & 0,168 \\
8 & 1,7 & 3,5 & 8,5 & 0,309 \\
9 & 0,22 & 2,45 & 5,75 & 0,035 \\
10 & 2,07 & 2,45 & 5,75 & $2,376 * * *$ \\
11 & 1,15 & 0,68 & 5,75 & 0,728 \\
12 & 1,15 & 4,214 & 5,75 & 1,210 \\
13 & 1,15 & 2,45 & 1,13 & 0,676 \\
14 & 1,15 & 2,45 & 10,37 & 0,824 \\
15 & 1,15 & 2,45 & 5,75 & 0,520 \\
16 & 1,15 & 2,45 & 5,75 & 0,516 \\
17 & 1,15 & 2,45 & 5,75 & 0,499 \\
18 & 1,15 & 2,45 & 5,75 & 0,510 \\
19 & 1,15 & 2,45 & 5,75 & 0,530 \\
20 & 1,15 & 2,45 & 5,75 & 0,497 \\
\hline
\end{tabular}

* Quantidade de Metanol adicionada em $\mathrm{mL}(\%$ - v/v)

** Uréia e extrato de levedura na proporção de 1,34:1,00 (\% - p/v)

*** Melhor resultado obtido para a composição do meio de cultura.

As atividades de $\beta$-xilosidase máxima e mínima, foram obtidas com os meios 10 e 9 , respectivamente (Tabela 17). Os resultados obtidos foram submetidos à análise estatística, inicialmente através do gráfico de Pareto, o qual apresenta os efeitos de cada fator em gráfico e numericamente, assim como os das suas interações.

O gráfico de Pareto foi utilizado para comparar a atividade de HXYLA recombinante produzida em todos os meios. A linha azul indica a magnitude mínima de efeitos estatisticamente significativos para um nível de confiança de $95 \%$. O gráfico de Pareto mostra claramente que a concentração da fonte de nitrogênio e a densidade 
celular inicial não tiveram efeito significativo sobre a produção da enzima HXYLA, enquanto a concentração de metanol afetou consideravelmente a sua produção (Fig. 32).

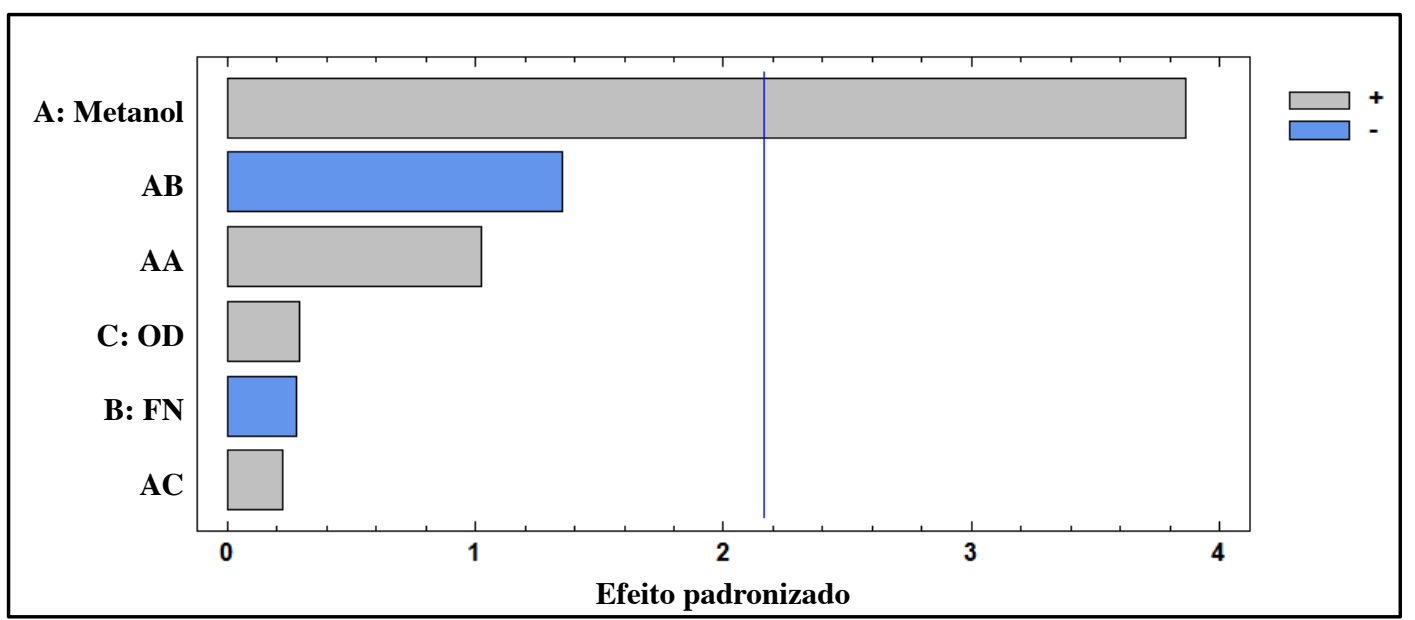

Figura 32 - Gráfico de Pareto mostrando o efeito da composição do meio de cultura sobre a produção da HXYLA por $\boldsymbol{P}$. pastoris. $\mathrm{O}$ gráfico de Pareto mostra os valores do teste $t$ de Student para cada componente médio. A linha azul indica o nível de confiança de $95 \%$ (isto é, $\mathrm{P}=0,05$ ). Valores à direita desta linha são estatisticamente significativos. $\mathrm{O}$ experimento foi realizado em triplicata biológica lidos em triplicata.

A partir dos resultados também foi possível realizar análise de variância segundo método de Fisher (ANOVA) apresentada na tabela 18. Na ANOVA para a atividade enzimática $(\mathrm{U} / \mathrm{mL})$ como variável resposta, apenas a concentração de metanol apresentou significância individualmente. Os resultados obtidos pela ANOVA, estão de acordo com os apresentados na análise realizada pelo método baseado na estatística $t$ de Student (gráfico de Pareto).

Tabela 18 - Análise de variância (ANOVA) para atividade enzimática da HXYLA (U/mL)

\begin{tabular}{cccccc}
\hline Fonte & $\begin{array}{c}\text { Soma dos } \\
\text { quadrados }\end{array}$ & Gl* $^{*}$ & $\begin{array}{c}\text { Média } \\
\text { quadrática }\end{array}$ & $\mathbf{F}_{\mathbf{0}}$ & Valor-P \\
\hline Metanol (A) & 2,604 & 1 & 2,604 & 14,94 & 0,0019 \\
FN** (B) & 0,013 & 1 & 0,013 & 0,08 & 0,7851 \\
OD (C) & 0,014 & 1 & 0,014 & 0,09 & 0,7752 \\
AA & 0,182 & 1 & 0,182 & 1,05 & 0,3247 \\
AB & 0,316 & 1 & 0,316 & 1,82 & 0,2009 \\
AC & 0,008 & 1 & 0,008 & 0,05 & 0,8285 \\
Erro & 2,266 & 13 & 0,174 & & \\
Total & 5,406 & 19 & & & \\
*Gl - Grau de liberdade; $* * F N-$ Fonte de nitrogênio & &
\end{tabular}

O comportamento da variável de resposta frente aos três fatores avaliados é mostrado nos gráficos de superfie de resposta apresentados na Figura 33. Nestas figuras observa-se como o modelo se ajusta apropriadamente aos resultados experimentais e como a variável de resposta é fortemente influenciada pela concentração de metanol. 
O modelo que descreve o comportamento da produção de HXYLA por $P$. pastoris, frente a variação da concentração de metanol, fonte de nitrogênio e OD inicial foi apresentado na equação 1, e pode ser usado para explicar melhor os resultados da análise estatística.

Equação 1:

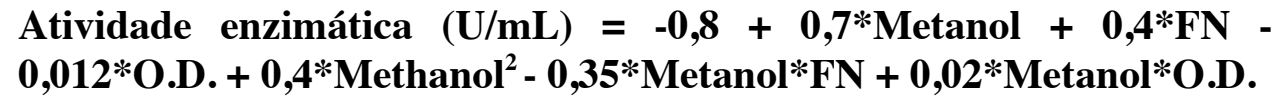

De acordo com o modelo obtido, o melhor resultado para produção de HXYLA foi obtido com o meio BMMY-U contendo 2,07\% de metanol, 2,45\% de fonte de nitrogênio e 5,75 de $\mathrm{OD}_{600}$ inicial. Comparando com o resultado obtido sem a otimização da produção $(0,67 \mathrm{U} / \mathrm{mL}$ com $1 \%$ de metanol), após a otimização foi obtido 2,37 U/mL de atividade de HXYLA, o que equivale a um aumento de cerca de $253 \%$.

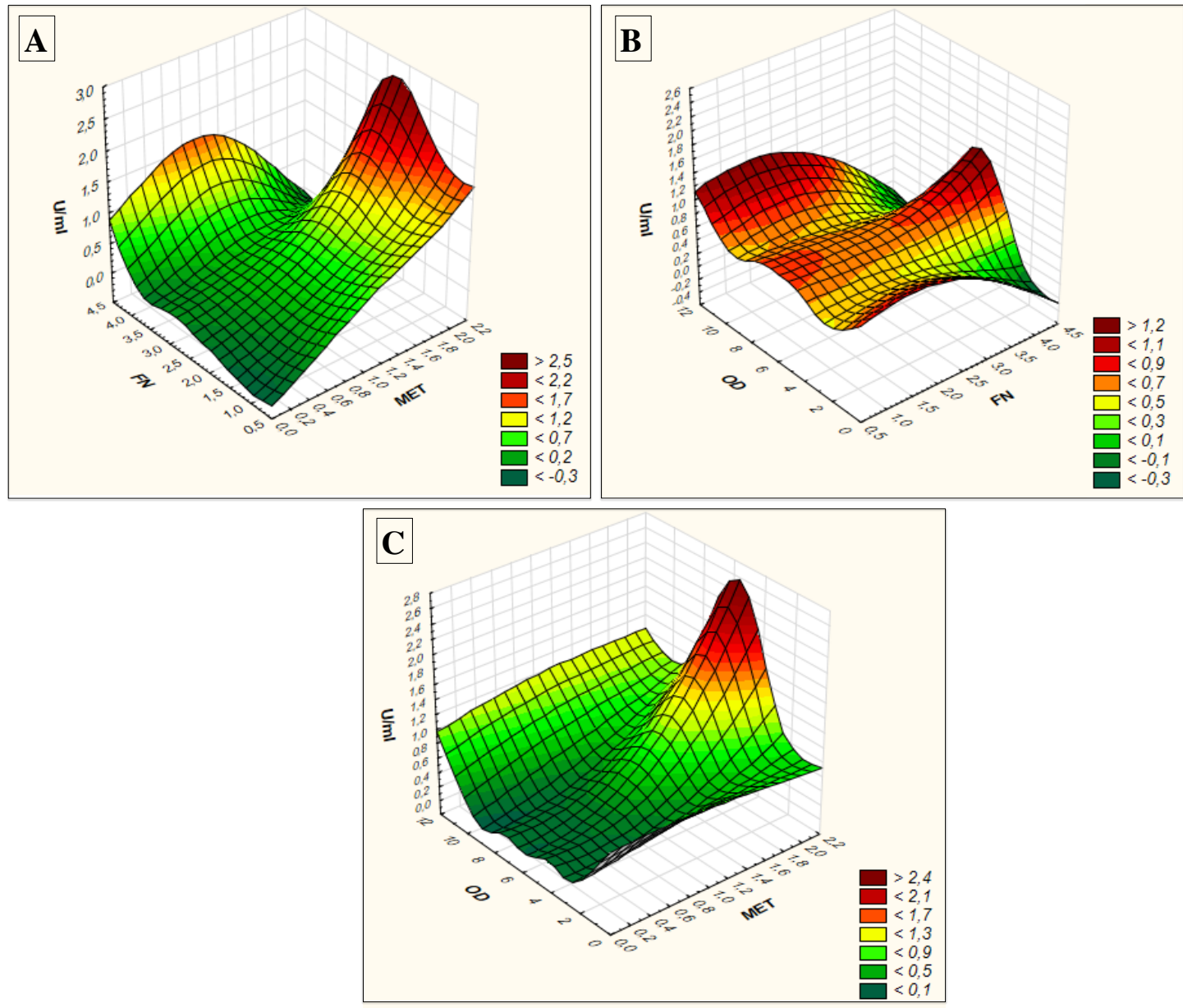

Figura 33 - Gráfico de superfície de resposta para a atividade de enzima HXYLA, em termos dos efeitos: (A) Concentração de metanol e fonte de nitrogênio, (B) Fonte de nitrogênio e OD inicial, (C) Concentração de metanol e OD inicial. 
O monitoramento da concentração de metanol é um processo de extrema importâcia, uma vez que altos níveis de metanol (Superior a $5 \mathrm{~g} / \mathrm{L}$ ) podem ser tóxicos para as células e baixos níveis de metanol podem não ser suficientes para iniciar transcrição (MACAULEY-PATRICK et al., 2005). Um exemplo disso, foi para produção de uma endo-xilanase (XYN11) do fungo Fusarium oxysporum produzida em $P$. pastoris $\mathrm{X} 33$, onde o aumento da concentração de metanol foi inversamente proporcional a atividade enzimática, sendo a melhor concentração para produção da enzima de 0,5\% (MOUKOULI; TOPAKAS; CHRISTAKOPOULOS, 2011).

Diferente do resultado encontrado para HXYLA, na produção de uma endoxilanase de T. lanuginosus IOC-4145 em P. pastoris, onde também foi realizada uma otimização da produção com planejamento fatorial $2^{3}$, verificou-se que a densidade celular inicial foi o parâmetro mais importante (DAMASO et al., 2003). Durante a otimização da produção da endoxilanase (HXYN2) de H. grisea por P. pastoris também foi verificado que o fator que exerceu influência significativa foi a $\mathrm{OD}_{600}$ inicial, enquanto o metanol e a fonte de nitrogênio não afetaram significativamente a produção da enzima (CARVALHO, W. R., 2008).

Para a otimização $\left(2^{3}\right)$ da produção de uma endo-glucanase de $P$. echinulatum por P. pastoris, foi observado um aumento de $180 \%$ da produção após a otimização e a interação entre densidade celular inicial e a concentração de metanol foi significativa, mostrando que com o aumento ou diminuição de ambos fatores a atividade enzimática pode ser aumentada (RUBINI et al., 2010).

$\mathrm{O}$ pH do meio de crescimento/indução também desempenha um importante papel na produção da proteína heteróloga, uma vez que a taxa de crescimento das células e as atividades das enzimas envolvidas no metabolismo de metanol e proteólise são dependentes de $\mathrm{pH}$ do meio de cultura (MINJIE; ZHONGPING, 2013). A influência do pH inicial do meio de indução da enzima HXYLA foi avaliada e o melhor resultado obtido foi com pH 7,0 (Fig 34). 


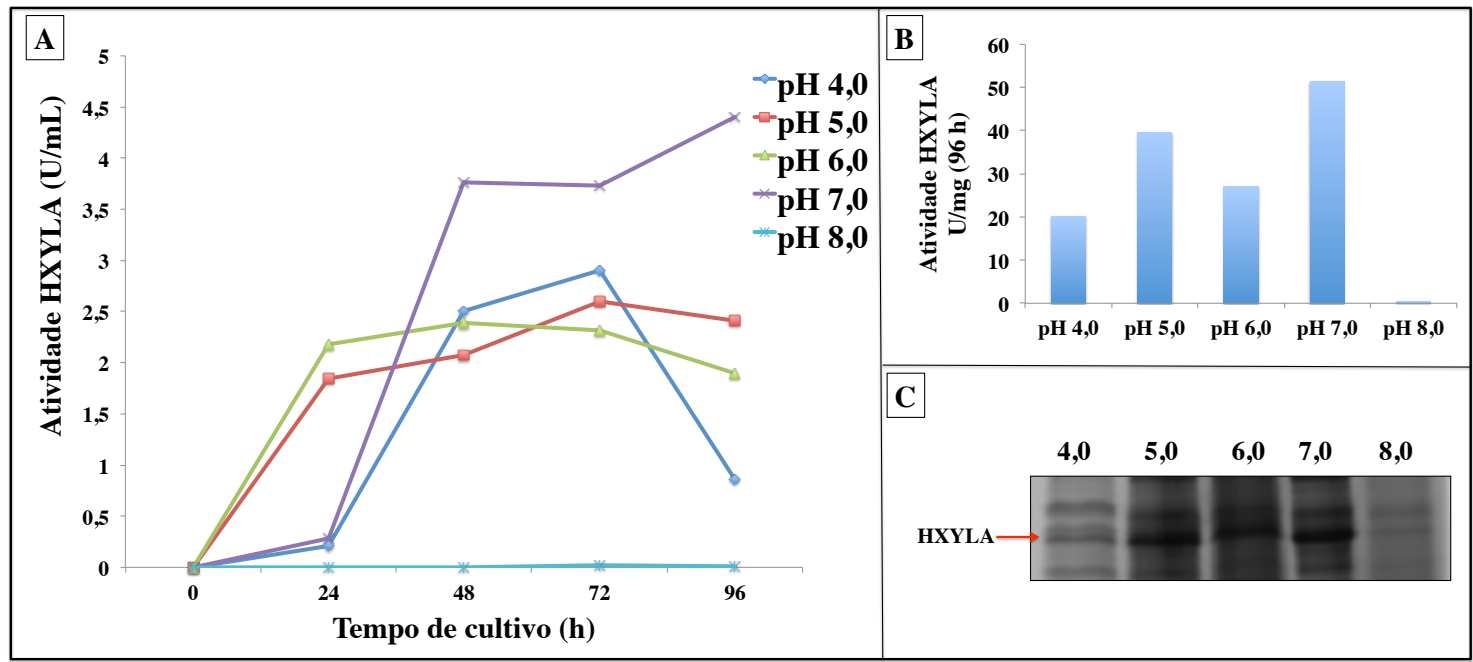

Figura 34 - Efeito do pH inicial do meio de cultura na produção de HXYLA por $P$. pastoris. A: Cinética da produção de HXYLA (U/ml) pelo transformante T92 de P. pastoris cultivado na presença de diferentes valores $\mathrm{pHs}$; B: Atividade específica $(\mathrm{U} / \mathrm{mg})$ dosado em 96 h; C: SDS-PAGE do sobrenadante de cultura do ponto $96 \mathrm{~h}$, a seta indica a banda de $37 \mathrm{kDa}$ correspondente a HXYLA. O resultado representa a média e o desvio padrão de 2 duplicatas biológicas analisadas em triplicata.

Segundo a literatura, $P$. pastoris pode crescer em uma ampla faixa de $\mathrm{pH}$ que varia de 3,0 a 8,0 (MINJIE; ZHONGPING, 2013). O valor de $\mathrm{pH}$ ótimo depende fortemente da natureza da proteína recombinante e a sua estabilidade. Normalmente, o pH é ajustado para inibir a atividade de proteases secretadas por P. pastoris no meio de cultura durante a fase de produção da enzima (AHMAD et al., 2014)

Alguns trabalhos relatam que uma das formas de minimizar a degradação proteolítica é utilizar pHs mais ácidos, entretanto, para a produção da HXYLA o melhor $\mathrm{pH}$ foi neutro $(7,0)$ e no $\mathrm{pH} 8,0$ praticamente não houve produção da enzima. Vale ressaltar que a taxa de crescimento celular foi menor no $\mathrm{pH} 8,0$ que os demais. Similiar aos nossos resultados, o pH 7,0 (120 U/mL) também foi o melhor para produção da XYN11 de $F$. oxysporum produzida em $P$. pastoris e diferente dos nossos resultados, a enzima XYN11 foi produzida até pH 9,0 (70 U/mL) (MOUKOULI; TOPAKAS; CHRISTAKOPOULOS, 2011).

Para produção de uma endoglucanase (NCEL5A) de Volvariella volvacea WX32 por P. pastoris (GS115) o melhor $\mathrm{pH}$ inicial foi o de 7,5 enquanto a atividade diminuiu no meio com pH mais ácido. A concentração de metanol também foi avaliada para produção da NCEL5A e foi obtido resultado similar ao obtido para HXYLA, onde a concentração de $2 \%$ final de metanol foi a melhor (LI et al., 2011).

Com a otimização por DCCR houve um aumento da atividade de HXYLA de $253 \%$ comparando com a atividade sem otimização. Após a complementação desses 
resultados com a otimização do pH inicial para produção da enzima, foi aumentado de 2,37 U/mL para 4,32 U/mL em $96 \mathrm{~h}$. Se compararmos o obtido no início com a produção sem otimização ( $1 \%$ metanol e pH 5,0 - 0,67 U/mL) houve um aumento 544 $\%$ na atividade da enzima. Esses resultados demonstram a importância de se realizar a otimização da produção quando se deseja alcançar níveis elevados da produção das enzimas por $P$. pastoris. Após a realização da otimização, foi realizada nova cinética para acompanhamento da produção de HXYLA por $P$. pastoris seguindo os melhores resultados obtidos (Metanol 2\% e pH inicial de 7,0) (Fig. 35).

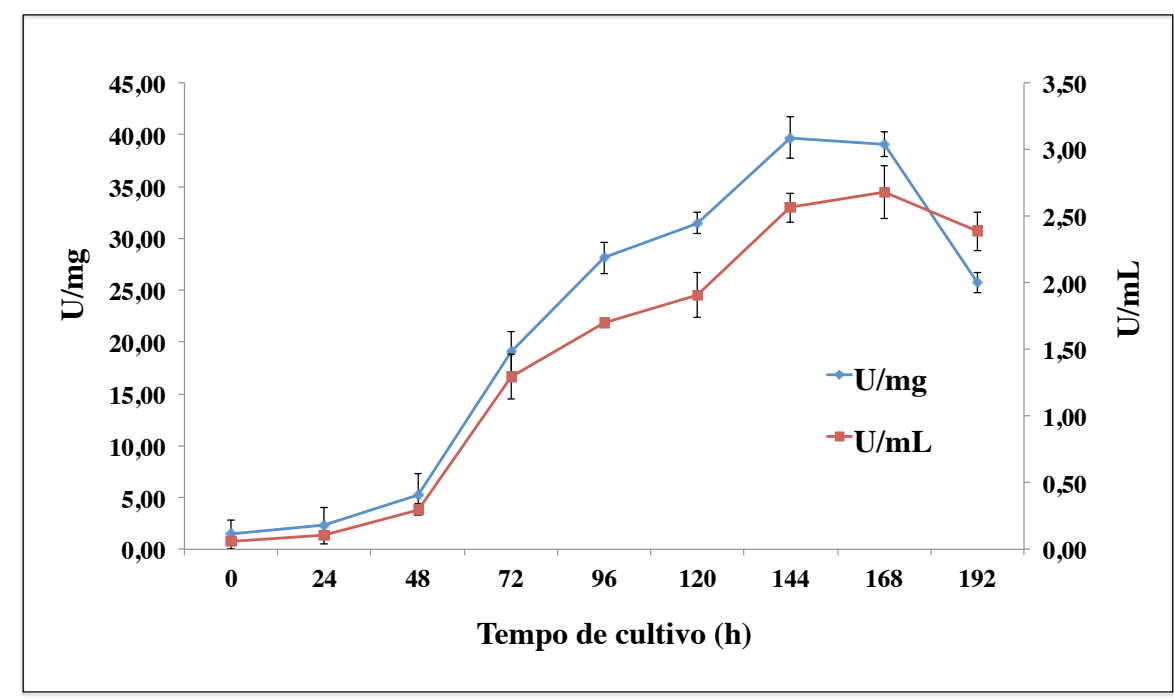

Figura 35 - Cinética da produção de HXYLA por $P$. pastoris por 192 h de cultivo na presença de $2 \%$ de metanol e pH inicial de 7,0. A linha azul mostra os valores em U/mg e a linha vermelha mostra os valores em $\mathrm{U} / \mathrm{mL}$.

O pico de produção da enzima HXYLA foi obtido após 144 h de cultivo com 39,7 U/mg (Fig. 36). O aumento na densidade celular foi acompanhado do aumento na produção da enzima, como observado nas Figuras 35 e 36 A. O perfil de proteínas secretadas foi analisado em gel SDS-PAGE e foi possível observar a banda de $37 \mathrm{kDa}$ aumentando a intensidade conforme o aumento da $\mathrm{OD}_{600}$ e atividade (Fig $36 \mathrm{~B}$ ). 


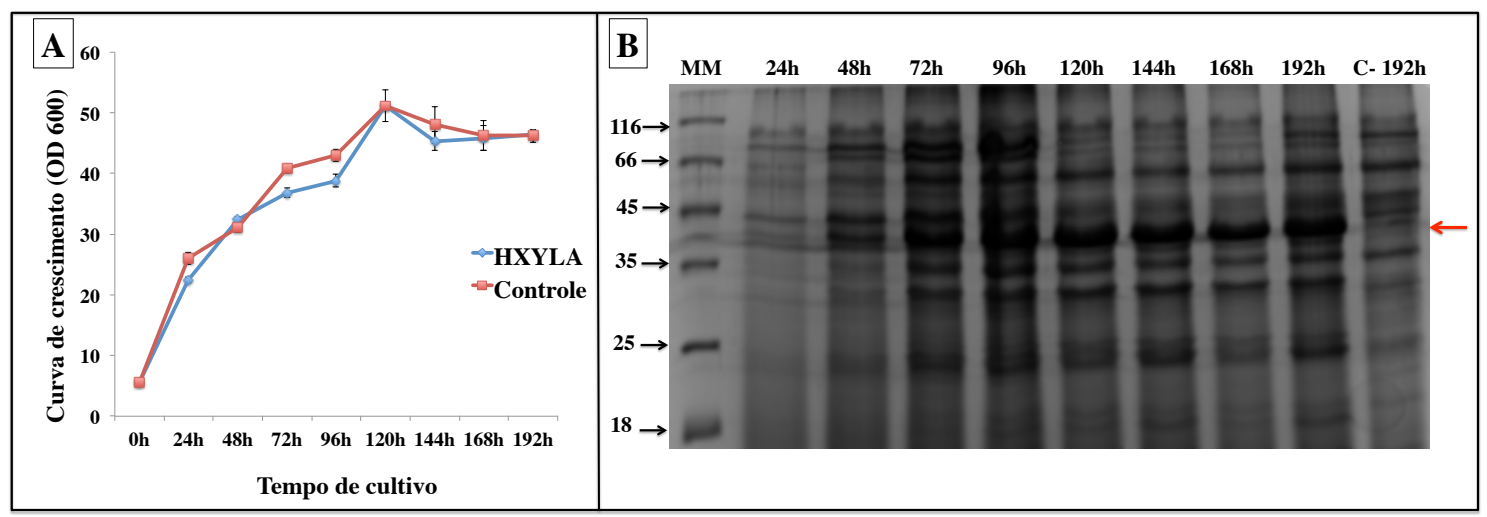

Figura 36 - Cinética da produção de HXYLA por $P$. pastoris 192 horas na presença de $2 \%$ de metanol e pH inicial de 7,0. A: Análise do crescimento do transformante produtor da HXYLA e do controle negativo. B: Perfil das proteínas secretadas no sobrenadante de cultura Gel SDS-PAGE PAGE. MM: marcador molecular; Sobrenadante de cultura após 24, 48, 72, 96, $120,144,168$ e 192 h de cultivo e sobrenadante de cultura após 192 h de cultivo do controle negativo (C- $192 \mathrm{~h})$. A seta vermelha indica a banda correspondente a HXYLA. Todas as amostras foram precipitadas por TCA.

\subsubsection{6 - Purificação da enzima recombinante (HXYLA) e Zimograma}

Alguns trabalhos publicados descrevem os processos de purificação de $\beta$ xilosidases produzidas de forma heteróloga por P. pastoris. Um fato observado nestes trabalhos foi a grande variabilidade de técnicas utilizadas, normalmente usa-se mais de uma etapa de purificação para o isolamento das proteínas. Dentre as etapas de purificação mais citadas, destacam-se as cromatografias de afinidade, de interação hidrofóbica e de exclusão molecular e o fracionamento com sulfato de amônio (KIRIKYALI; CONNERTON, 2014; RAVANAL et al., 2013; XIA et al., 2015; YANG et al., 2014).

No presente trabalho, foi necessária apenas uma etapa de purificação. Para isso, o sobrenadante de cultura de $P$. pastoris coletado após indução de 96 h e concentrado aproximadamente 20 vezes por ultrafiltração em membrana de $10 \mathrm{kDa}$. Após a ultrafiltração a quantidade de proteína presente no sobrenadante foi de 157,17 \pm 0,16 mg e a atividade específica de $\beta$-xilosidase de $10,1 \mathrm{U} / \mathrm{mg}$ de proteína.

O resumo do processo de purificação da enzima HXYLA de $H$. grisea produzida por $P$. pastoris está descrito na tabela 19. O rendimento observado na purificação foi de $16 \%$ e o fator de purificação de 1,4. A atividade específica obtida após a finalização da purificação foi de $34,1 \mathrm{U} / \mathrm{mg}$. 
Tabela 19 - Resumo do processo de purificação da HXYLA produzida por $P$. pastoris.

\begin{tabular}{ccccccc}
\hline $\begin{array}{c}\text { Passos da } \\
\text { purificação }\end{array}$ & $\begin{array}{c}\text { Volume } \\
(\mathrm{mL})\end{array}$ & $\begin{array}{c}\text { Atividade } \\
\text { total }(\mathrm{U})\end{array}$ & $\begin{array}{c}\text { Proteína total } \\
(\mathrm{mg})\end{array}$ & $\begin{array}{c}\text { Atividade } \\
\text { específica } \\
(\mathrm{U} / \mathrm{mg})\end{array}$ & $\begin{array}{c}\text { Fator de } \\
\text { purificação }\end{array}$ & $\begin{array}{c}\text { Rendimento } \\
(\%)\end{array}$ \\
\hline $\begin{array}{c}\text { Sobrenadante } \\
\text { de cultura }\end{array}$ & 100 & $199 \pm 0,06$ & $8,3 \pm 0,001$ & $24 \pm 0,8$ & 1.0 & $100 \%$ \\
$\begin{array}{c}\text { Ultrafiltração } \\
\text { Superdex 75 }\end{array}$ & 3 & $157,17 \pm 0,16$ & $15,52 \pm 0,036$ & $10,1 \pm 0,3$ & 0.42 & $79 \%$ \\
\hline
\end{tabular}

Em comparação, algumas $\beta$-xilosidases fungicas purificadas apresentaram valores de atividades específicas (U/mg de proteína) menores que o obtido neste trabalho: 19,6 para $\beta$-xilosidase de H. grisea (IEMBO et al., 2006), 3.42 para $\beta$ xilosidase de T. harzianum (XIMENES; DE PAULA SILVEIRA; F FILHO, 1996) e mais baixa que para $\beta$-xilosidase de $P$. thermophila J18 com 43,4 U/mg (YAN et al., 2008), 175 para para $\beta$-xilosidase de $H$. grisea (DE ALMEIDA et al., 1995)

A enzima recombinante foi purificada e mostrou uma banda única quando analisado por SDS-PAGE, com uma massa molecular de aproximadamente $37 \mathrm{kDa}$ (linha 2 da Fig. 37), que coincide com a banda de atividade obtida no zimograma com MUX como substrato (linha 3 da Fig. 37).

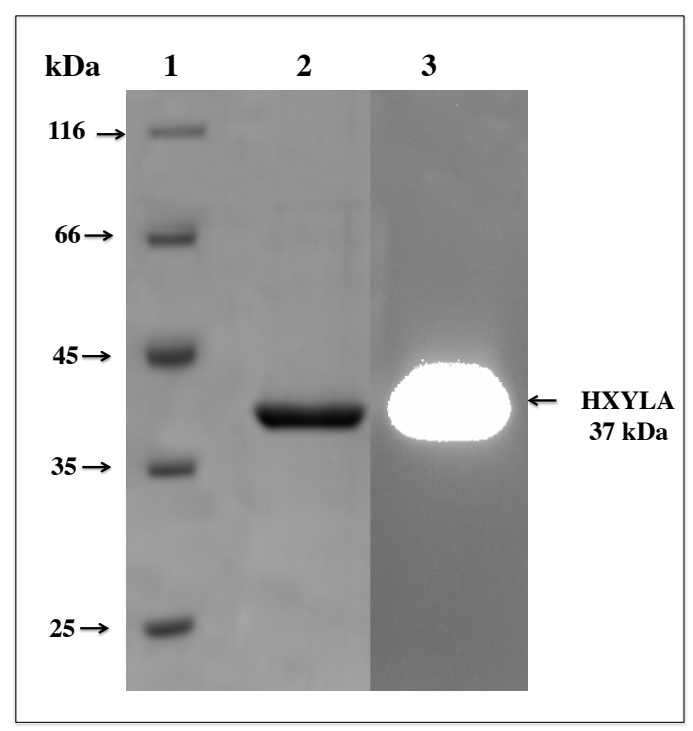

Figura 37 - SDS-PAGE corado por azul de comassie $(13 \%)$ e zimograma da proteína recombinante HXYLA purificada. 1 - Marcador molecular (Thermo Scientific); 2 - HXYLA purificada $( \pm 3 \mu \mathrm{g}$ de proteína purificada; 3 - Zimograma da HXYLA utilizando MUX como substrato. 
A massa molecular da HXYLA purificada foi de $37 \mathrm{kDa}$ determinada por SDSPAGE, sendo uma proteína monomérica. Muitas $\beta$-xilosidases exibem massa molecular acima de $50 \mathrm{kDa}$ como, por exemplo, as $\beta$-xilosidases de $H$. insolens de 83,2 e $62 \mathrm{kDa}$ (XIA et al., 2015; YANG et al., 2014); 103,7 para $\beta$-xilosidase de Penicillium herquei IFO 4674 (ITO et al., 2003).

As $\beta$-xilosidases pertencentes família GH43 apresentam massa molecular prevista entre 35-62 kDa (KIRIKYALI \& CONNERTON, 2015). Isso está de acordo para $\beta$-xilosidases de $H$. insolens com 37,1 e 61,8 kDa (YANG et al., 2014), $P$. purpurogenum com $37 \mathrm{kDa}$ (RAVANAL et al., 2013), T. lanuginosus com 51,6 kDa (CHEN et al., 2012), T. lanuginosus SSBP com 50 kDa (GRAMANY et al., 2015).

\subsubsection{7 -Caracterização enzimática da enzima recombinante HXYLA.}

\subsubsection{1 -pH e temperatura ótima}

$\mathrm{O}$ efeito do $\mathrm{pH}$ e temperatura sobre a atividade da HXYLA foi avaliada. As propriedades da HXYLA, bem como, de outras $\beta$-xilosidases de fungos pertencentes a família GH43 estão apresentados na Tabela 20. O pH ótimo encontrado para a enzima foi $\mathrm{pH} \mathrm{7,0} \mathrm{(Fig.} 38$ A). Isto está de acordo com a maioria das $\beta$-xilosidases da família GH43 de fungos apresentando pH óptimo variando de 6,0-7,0 (Tabela 20). As $\beta$ xilosidase da maioria dos fungos, incluindo outras famílias das glicosil hidrolases, têm uma atividade ótima em pHs ácidos entre 4,0 e 6,0 (KNOB; TERRASAN; CARMONA, 2010).

A temperatura ótima para a enzima HXYLA foi de $50{ }^{\circ} \mathrm{C}$ (Fig. $38 \mathrm{C}$ ). As $\beta$ xilosidases de fungos mesófilos e termófilos apresentam uma temperatura ótima que varia entre 50 e $70^{\circ} \mathrm{C}$ e a sua estabilidade térmica é altamente variável dependendo das diferenças estruturais (KIRIKYALI; CONNERTON, 2015).

A estabilidade térmica e a estabilidade da HXYLA em diferentes pHs foram analisadas durante $48 \mathrm{~h}$, esse tempo de análise é superior ao apresentado para a maioria dos ensaios descritos na literatura. Isso é interessante para avaliar as possibilidades de aplicação desta enzima em diversos processos biotecnológicos. 


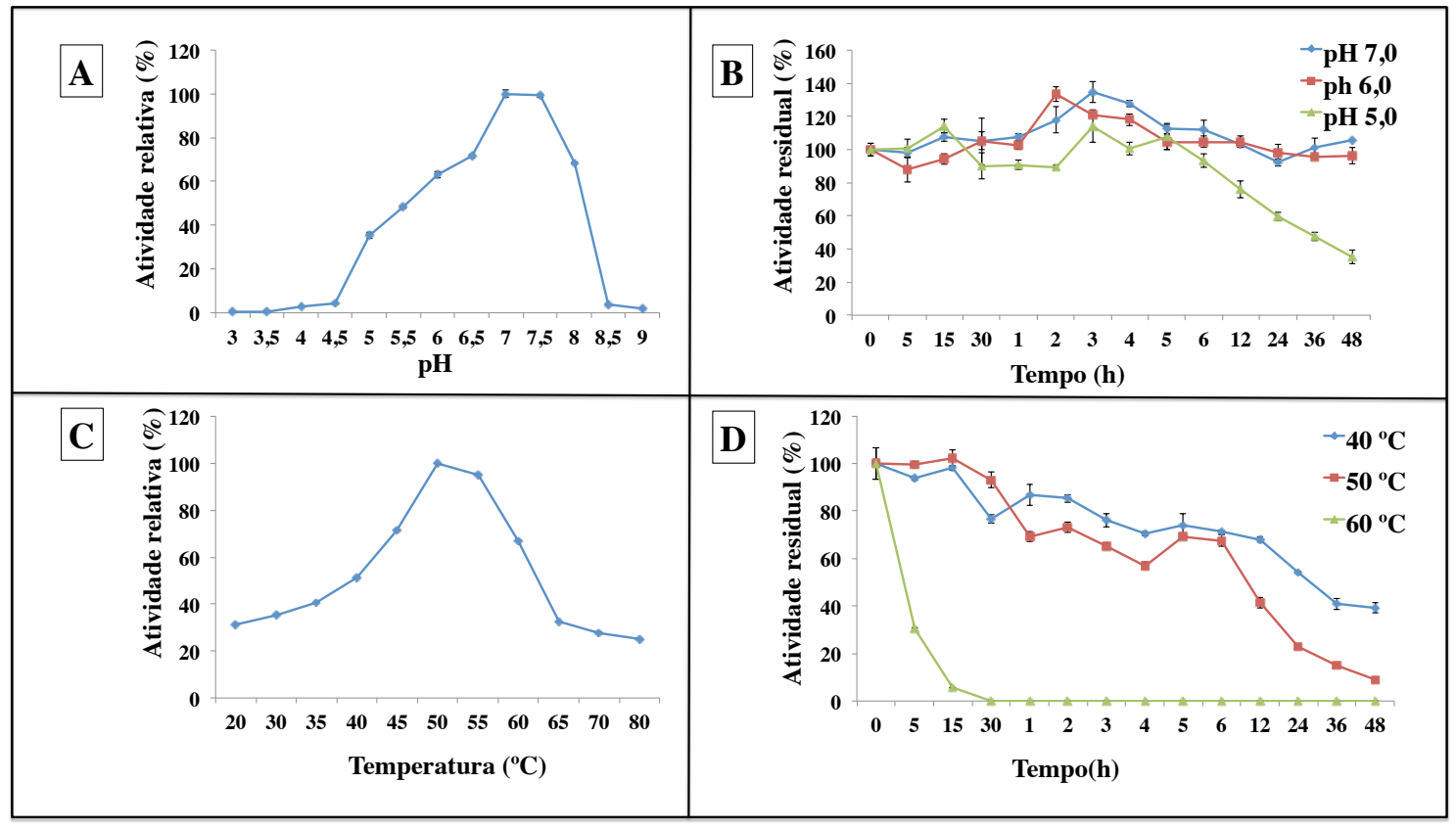

Figura 38 - Efeito da temperatura e do $\mathrm{pH}$ sobre as propriedades enzimáticas da HXYLA recombinante. A: $\mathrm{pH}$ ótimo em tampão McIlvaine, $\mathrm{pH}$ 3,0-8,0; Tris- $\mathrm{HCl}, \mathrm{pH}$ 8,0-9,0; $\mathrm{B}$ : estabilidade em pH (Mcllvaine $\mathrm{pH} 5,0 ; 6.0$ e 7.0 a $40{ }^{\circ} \mathrm{C}$ ); $\mathrm{C}$ : Temperatura ótima; D: Estabilidade em temperatura $\left(40{ }^{\circ} \mathrm{C}, 50{ }^{\circ} \mathrm{C}\right.$ e $\left.60{ }^{\circ} \mathrm{C}, \mathrm{pH} 7.0\right)$.

A estabilidade térmica foi monitorada durante $48 \mathrm{~h}$, nas temperaturas de $40{ }^{\circ} \mathrm{C}$, $50{ }^{\circ} \mathrm{C}$ e $60{ }^{\circ} \mathrm{C}$. A enzima se manteve estável a $40{ }^{\circ} \mathrm{C}$, mas na a temperatura ótima de 50 ${ }^{\circ} \mathrm{C}$, a enzima se manteve estável por até 12 horas, mantendo $42 \%$ da atividade. Este resultado foi melhor do que o mostrado para uma $\beta$-xilosidase de $T$. lanuginosus que reteve $60 \%$ durante 60 min a $50{ }^{\circ} \mathrm{C}$ (GRAMANY et al., 2015). A $40{ }^{\circ} \mathrm{C}$ a enzima HXYLA reteve $54 \%$ de atividade durante 24 h e reduziu a atividade para $40 \%$ durante 48 h (Fig. 38 D). A estabilidade do pH foi acompanhada e em pH 6,0 e 7,0 a enzima manteve $95 \%$ da sua atividade durante 48 h (Fig. 38 B).

Esses dados sugerem que a enzima é termoestável e mantem a estabilidade no pH ótimo após um longo tempo de incubação, características importantes quando se busca enzimas para diferentes aplicações biotecnológicas. 
Tabela 20 - Propriedades das enzimas fúngicas da família GH43.

\begin{tabular}{|c|c|c|c|c|c|c|c|c|c|}
\hline Espécie & $\begin{array}{c}\text { Massa molecular } \\
\text { (kDa) }\end{array}$ & pH ótimo & $\begin{array}{c}\text { Temperatura } \\
\text { ótima }\left({ }^{\circ} \mathbf{C}\right)\end{array}$ & $\begin{array}{c}\text { Atividade } \\
\text { específica (U/ mg) }\end{array}$ & $\begin{array}{c}* \mathbf{K} \mathbf{m} \\
(\mathbf{m M})\end{array}$ & $\begin{array}{c}\mathrm{V}_{\mathrm{max}} \\
(\mu \mathrm{mol} / \mathrm{min} / \mathrm{mg})\end{array}$ & $\begin{array}{l}* * \mathbf{K} i \\
(\mathbf{m M})\end{array}$ & $\begin{array}{l}\text { Expresso } \\
\text { por }\end{array}$ & Refs \\
\hline $\begin{array}{c}\text { H.grisea } \\
\text { (HXYLA) }\end{array}$ & 37 & 7,0 & $50{ }^{\circ} \mathrm{C}$ & 34,1 & 2,13 & 52,3 & 350 & P.pastoris & Este trabalho \\
\hline \multicolumn{10}{|l|}{ H. insolens Y1 } \\
\hline (Xyl43A) & 37,1 & 6,5 & $50{ }^{\circ} \mathrm{C}$ & 20,5 & 12,2 & 203,8 & 79 & E. coli & \multirow[t]{2}{*}{$\begin{array}{l}\text { (YANG et al., 2014, } p \\
43 \text { ) }\end{array}$} \\
\hline $\begin{array}{c}\text { H. insolens Y1 } \\
(\mathrm{Xyl} \text { Y3B })\end{array}$ & 61,8 & 7,0 & $50{ }^{\circ} \mathrm{C}$ & 1,7 & 1,29 & 2,18 & 292 & E. coli & \\
\hline $\begin{array}{l}\text { P.purpurogenum } \\
\text { (Xyl1) }\end{array}$ & 49 & 6,0 & $40{ }^{\circ} \mathrm{C}$ & - & 0,55 & - & 2,5 & P.pastoris & $\begin{array}{l}\text { (RAVANAL et al., } \\
\text { 2013) }\end{array}$ \\
\hline $\begin{array}{c}\text { P. chrysosporium } \\
\text { (PcXyl) }\end{array}$ & 83 & 5,0 & $45^{\circ} \mathrm{C}$ & 1797 & 12,7 & 2812 & - & P.pastoris & (HUY et al., 2013b) \\
\hline $\begin{array}{l}\text { P. thermophila } \\
\text { (PtXyl43) }\end{array}$ & 52,3 & 7,0 & $55^{\circ} \mathrm{C}$ & 45,4 & 4,5 & 90,2 & - & E. coli & (TENG et al., 2011) \\
\hline A. oryzae $(\mathrm{XylB})$ & 37,4 & 7,0 & $30{ }^{\circ} \mathrm{C}$ & 6,1 & 0,48 & 42,6 & - & E. coli & (SUZUKI et al., 2010) \\
\hline $\begin{array}{l}\text { T. lanuginosus } \\
\text { (TIXyl43) }\end{array}$ & 51,6 & 6,5 & $55^{\circ} \mathrm{C}$ & 45,4 & 3,9 & 107,6 & 63 & E. coli & (CHEN et al., 2012) \\
\hline $\begin{array}{l}\text { T. lanuginosus } \\
\text { (TIXyn1) }\end{array}$ & 50 & 7,0 & $50{ }^{\circ} \mathrm{C}$ & 2,29 & - & - & - & P.pastoris & $\begin{array}{l}\text { (GRAMANY et al., } \\
\text { 2015) }\end{array}$ \\
\hline
\end{tabular}

* Km monitorado com o substrato pNPX

**Ki para xilose como inibidor 


\subsubsection{4-Parametros cinéticos}

Os parâmetros cinéticos Vmáx e Km para HXYLA foram obtidos pela equação da reta fornecida pelo método do duplo recíproco (1/Velocidade x $1 /$ Substrato). A velocidade da reação em função do substrato, foi determinada utilizando-se pNPX como substrato, nas concentrações de 0,066 a 13,33 mM. Os parâmetros cinéticos foram calculados a partir de gráficos de Lineweaver-Burke das atividades específicas em várias concentrações de substrato. Os valores aparentes de Km e Vmax para pNPX como substrato foram de $2,13 \mathrm{mM}$ e $52,3 \mu \mathrm{mol} / \mathrm{min} / \mathrm{mg}$, respectivamente, sob condições de ensaio padrão (Fig. 39). Vale ressaltar que também realizado cálculos de Km e Vmáx utilizando a curva de Michaelis-Menten ajustada, utilizando o programa GraphPad Prism version 7 onde foi obtido um valor de $\mathrm{Km}$ de 1,89 mM e Vmáx de $51,57 \mu \mathrm{mol} / \mathrm{min} / \mathrm{mg}$, similar ao resultado obtido com os gráficos de Lineweaver-Burke.

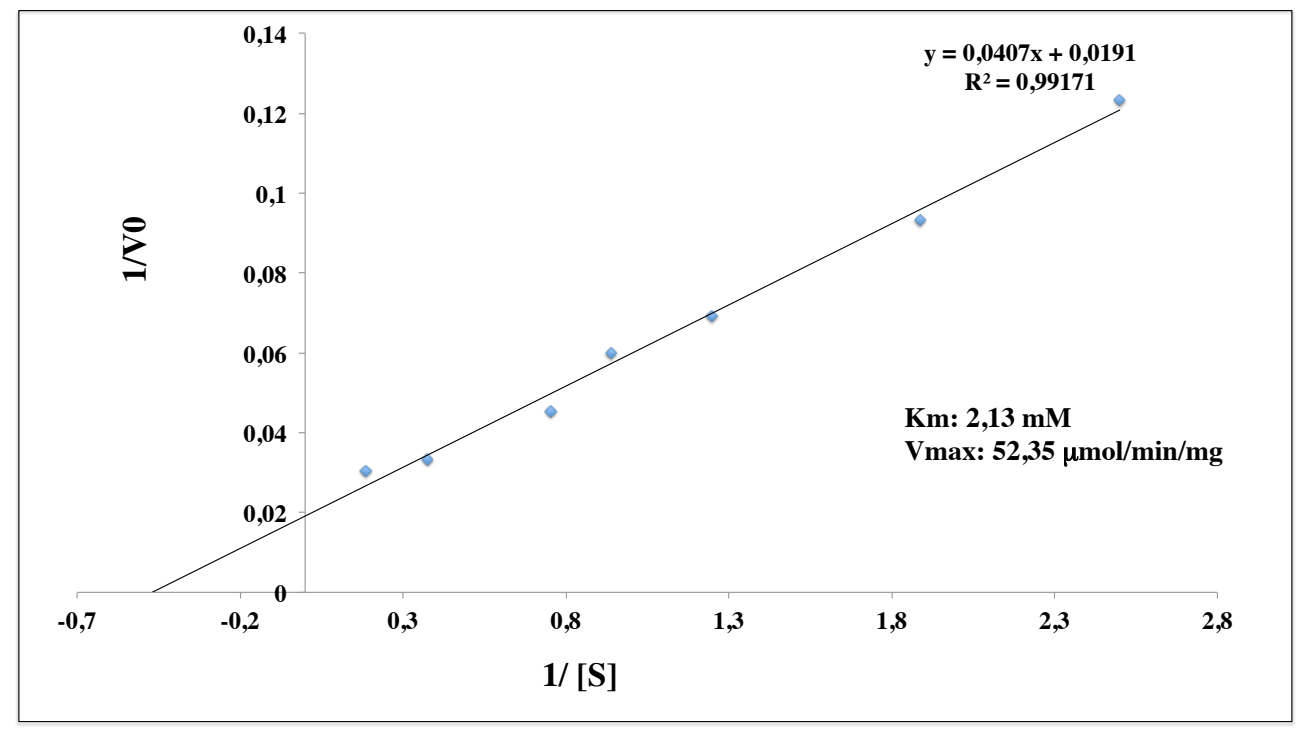

Figura 39 - Gráfico do duplo recíproco correlacionando o inverso da concentração do substrato com o inverso da velocidade da reação para a enzima HXYLA.

O valor de $\mathrm{Km}$ sugere uma afinidade mais elevada para pNPX quando comparado com o $\mathrm{Km}$ reportado para os outras $\beta$-xilosidases fúngicas da família GH43, como para $\beta$-xilosidases de $H$. insolens (Xyl43A) com o $\mathrm{Km}$ de 12,2 $\mathrm{mM}$ e de $P$. chrysosporium (PcXyl) com Km de 12,7 mM (Tabela 20) (HUY et al., 2013b; YANG et al., 2014). 


\subsubsection{2 - Efeito de íons metálicos e outros agentes químicos na atividade da HXYLA}

$\mathrm{O}$ efeito de íons e outros agentes químicos $(5 \mathrm{mM})$ sobre a atividade da enzima recombinante HXYLA foi verificado. A atividade foi realizada obedecendo as condições ótimas de $\mathrm{pH}$ e temperatura. A atividade da HXYLA foi totalmente inibida pelos íons $\mathrm{Hg}^{2+}, \mathrm{Cu}^{2+}$ and SDS, moderadamente influenciada por $\mathrm{Fe}^{2+}, \mathrm{Al}^{3+}$ and $\mathrm{Zn}^{2+} \mathrm{e}$ fracamente inibida por EDTA, $\mathrm{Mn}^{2+}$ and $\mathrm{Mg}^{2+}$. A enzima foi estimulada pela concentração de $5 \mathrm{mM}$ de $\beta$-mercaptoetanol, $\mathrm{Ag}^{+}, \mathrm{Ba}^{2+}, \mathrm{Ca}^{2+}, \mathrm{K}^{+}, \mathrm{Li}^{+}, \mathrm{NH}_{4}^{+}$e $\mathrm{Na}^{+}$ (Tabela 21).

Tabela 21 - Efeito dos íons metálicos e reagentes químicos $(5 \mathrm{mM})$ na atividade da HXYLA.

\begin{tabular}{cc}
\hline Íons e agentes desnaturantes & Atividade Residual $^{\mathrm{A}}(\%)$ \\
\hline Controle & $100 \pm 0,2$ \\
$\mathrm{Hg}^{2+}$ & 0 \\
$\mathrm{SDS}^{2+}$ & 0 \\
$\mathrm{Cu}^{2+}$ & 0 \\
$\mathrm{Zn}^{2+}$ & $33 \pm 0,1$ \\
$\mathrm{Al}^{3+}$ & $50 \pm 0,2$ \\
$\mathrm{Fe}^{3+}$ & $42 \pm 0,3$ \\
$\mathrm{EDTA}^{2+}$ & $90 \pm 0,1$ \\
$\mathrm{Mg}^{2+}$ & $81 \pm 0,1$ \\
$\mathrm{Mn}^{2+}$ & $93 \pm 0,3$ \\
$\mathrm{Ca}^{2+}$ & $110 \pm 0,1$ \\
$\mathrm{~K}^{+}$ & $125 \pm 0,3$ \\
$\mathrm{Li}^{+}$ & $122 \pm 0,3$ \\
$\mathrm{Ba}^{2+}$ & $108 \pm 0,2$ \\
$\beta-\mathrm{Mercaptoetanol}^{2+}$ & $105 \pm 0,2$ \\
$\mathrm{NH}_{4}^{+}$ & $117 \pm 0,2$ \\
$\mathrm{Na}^{+}$ & $113 \pm 0,4$ \\
$\mathrm{Ag}^{+}$ & $113 \pm 0,4$ \\
\hline Os valores representam a média e o desvio padrão de 6 experimentos diferentes.
\end{tabular}

Uma $\beta$-xilosidase nativa de $H$. grisea de $50 \mathrm{kDa}$ também foi estimulada por $\beta$ mercaptoetanol com atividade relativa de $109.18 \%$ (IEMBO et al., 2006) e a de 43 kDa apresentou resultado similar ao obtido pela $\mathrm{HXYLA}$ em relações aos íons $\mathrm{Hg}^{2+} \mathrm{e} \mathrm{Cu}^{2+}$ sendo completamente inibida (DE ALMEIDA et al., 1995).

Os íons $\mathrm{Fe}^{3+}, \mathrm{Zn}^{2+}$ e o SDS são forte inibidores da atividade de $\beta$-xilosidases (ZHANG et al., 2014). A forte inibição mesmo em concentrações baixas de $\mathrm{Hg}^{2+}$ sugerem a importância do resíduo de triptofano na atividade da enzima 
(MCALLISTER; MARRONE; CLARKE, 2000). A forte inibição da enzima pelo SDS também já foi relatada para outras $\beta$-xilosidases, bem como para Geobacillus thermodenitrificans (JAIN; KUMAR; SATYANARAYANA, 2014), duas $\beta$-xilosidases de $H$. insolens (YANG et al., 2014) e T. harzianum (XIMENES; DE PAULA SILVEIRA; F FILHO, 1996). As interações hidrofóbicas podem ser a causa da sensibilidade ao SDS sendo importante para manutenção da conformação funcional.

\subsubsection{3 - Efeito de diferentes substratos na atividade da enzima HXYLA}

A enzima HXYLA foi capaz de hidrolizar o substrato sintético pNPX (100\%) e o pNPA (18\%) (Tabela 22). Esse resultado indica que essa enzima é bifuncional apresentando atividade de $\beta$-xilosidase e $\alpha$-L-arabinofuranosidase. Essa característica que é, normalmente, encontrada em membros da família GH43, ocorre devido à semelhança espacial da xilopiranose e arabinofuranose, permitindo a promiscuidade ao substrato, que é observada com relativa frequência em substratos como o pNPX e o pNPA e com menos frequência em substratos naturais (JORDAN et al., 2013).

Muitas $\beta$-xilosidases com atividade adicional de $\alpha$-L-arabinofuranosidases tem sido reportadas na literatura como, por exemplo, as $\beta$-xilosidases dos fungos $H$. insolens, P. purpurogenum, P. chrysosporium e Aspergillus japonicus (HUY et al., 2013b; RAVANAL et al., 2013; WAKIYAMA et al., 2008; YANG et al., 2014).

Tabela 22 - Capacidade da enzima HXYLA purificada hidrolisar diferentes substratos.

\begin{tabular}{cccc}
\hline Substrato & Concentração & $\begin{array}{c}\text { Tempo de } \\
\text { reação }\end{array}$ & $\begin{array}{c}\text { Atividade } \\
\text { residual (\%) }\end{array}$ \\
\hline pNPX & $5 \mathrm{mM}$ & $5 \mathrm{~min}$ & 100 \\
pNPA & $5 \mathrm{mM}$ & $5 \mathrm{~min}$ & 18 \\
pNPG & $5 \mathrm{mM}$ & $5 \mathrm{~min}$ & $\mathrm{nd}^{\mathrm{a}}$ \\
Xilobiose & $1 \mathrm{mM}$ & $1 \mathrm{~h}$ & 6,5 \\
Xilotriose & $1 \mathrm{mM}$ & $1 \mathrm{~h}$ & 10 \\
Xilotetraose & $1 \mathrm{mM}$ & $1 \mathrm{~h}$ & 14 \\
Celobiose & $1 \mathrm{mM}$ & $1 \mathrm{~h}$ & $\mathrm{nd}$ \\
Xilana Beechwood & $1 \%$ & $1 \mathrm{~h}$ & 3 \\
Xilana Oat spelt & $1 \%$ & $1 \mathrm{~h}$ & 0,48 \\
Arabinoxilana de trigo & $1 \%$ & $1 \mathrm{~h}$ & $\mathrm{nd}$ \\
CMC & $4 \%$ & $1 \mathrm{~h}$ & $\mathrm{nd}$ \\
Avicel & $1 \%$ & $1 \mathrm{~h}$ & $\mathrm{nd}$ \\
Papel de filtro & $8 \mathrm{mg}$ & $1 \mathrm{~h}$ & $\mathrm{nd}$ \\
\hline
\end{tabular}


A enzima HXYLA não apresentou atividade de celulase. Um resultado diferente foi encontrado para uma $\beta$-xilosidase de A.japonicus MU-2 que mostrou 31,6 \% e 1,5 $\%$ de atividade sobre o pNPG e celobiose, respectivamente (WAKIYAMA et al., 2008). Além disso, a enzima recombinante HXYLA apresentou atividade contra a xilana beechwood (3\%), o que é um resultado incomum. Na literatura, esse fato é relatado para uma $\beta$-xilosidase da família GH3 do fungo hemicelulolítico Talaromyces amestolkiae que também apresentou atividade contra xilana beechwood (NIETODOMÍNGUEZ et al., 2015b).

Recentemente, foi reportado uma enzima membro da família GH43 de Paenibacillus curdlanolyticus B-6 (Xyl43B6) que exibiu propriedades de $\alpha$-Larabinofuranosidase, $\beta$-xilosidase e endo-xilanase, sendo considerada uma enzima trifuncional (RATANAKHANOKCHAI et al., 2013).

A ação da enzima sobre xilobiose, xilotriose e xilotetraose também foi avaliada. A enzima recombinante HXYLA foi capaz de liberar xilose a partir de xilooligossacarídeos e a taxa da liberaçao aumentou conforme o tamanho da cadeia com 6,5\% de atividade relativa para xilobiose, $10 \%$ para xilotriose e $14 \%$ para xilotetraose. Um resultado similar foi obtido por uma $\beta$-xilosidase de por $P$. thermophila $\mathrm{J} 18$ que ao atuar sobre os xilooligosacarídeos também houve aumento da liberação de xilose conforme o aumento da cadeia (YAN et al., 2008).

Algumas XYLs atuam de outra forma, diminuindo a liberação de xilose conforme o aumento da cadeia, como foi relatado para $\beta$-xilosidases de A. oryzae e $N$. crassa (KIRIKYALI; CONNERTON, 2014; KIRIKYALI; WOOD; CONNERTON, 2014).

Em uma concentração fixa de xilooligosacarídeos, a atividade aumentou ligeiramente com o aumento do comprimento da cadeia, o que seria atípico para um $\beta$ xilosidase (JUTURU; WU, 2012) e típico para um exo-xilanase (HERRMANN et al., 1997). Esta conclusão é corroborada pela constatação de que a HXYLA foi capaz de liberar xilose a partir da xilana beechwood.

\subsubsection{4 - Inibição por xilose}

O efeito da xilose sobre a atividade da HXYLA foi avaliado conforme descrito no item 5.28.7. Enzimas que apresentam tolerância a xilose são interessantes para aplicação em vários processos biotecnológicos (KIRIKYALI; CONNERTON, 2015). As $\beta$-xilosidases contribuem para a diminuição do produto final (xilobiose) que causa 
inibição das endo-xilanases (POLIZELI et al., 2005). Contudo, várias $\beta$-xilosidases são totalmente ou parcialmente inibidas até mesmo em baixas concentrações de xilose como, por exemplo, uma $\beta$-xilosidase de $N$. crassa com valor de $\mathrm{K} i$ de 1,72 $\mathrm{mM}$ (KIRIKYALI; CONNERTON, 2014), de Fusarium proliferatum (NRRL 26517) com $\mathrm{K} i$ de 5,0 mM (SAHA, 2003) ou de A. oryzae com valor de $\mathrm{Ki}$ de 2,72 mM (KIRIKYALI; WOOD; CONNERTON, 2014).

A maioria das $\beta$-xilosidases descritas até o momento, exibem valor de $\mathrm{K} i$ que varia de 2 a 10 mM (KNOB; TERRASAN; CARMONA, 2010) e este resultado é muito inferior ao valor encontrado para a enzima recombinante HXYLA que foi de $350 \mathrm{mM}$ (Fig. 40).

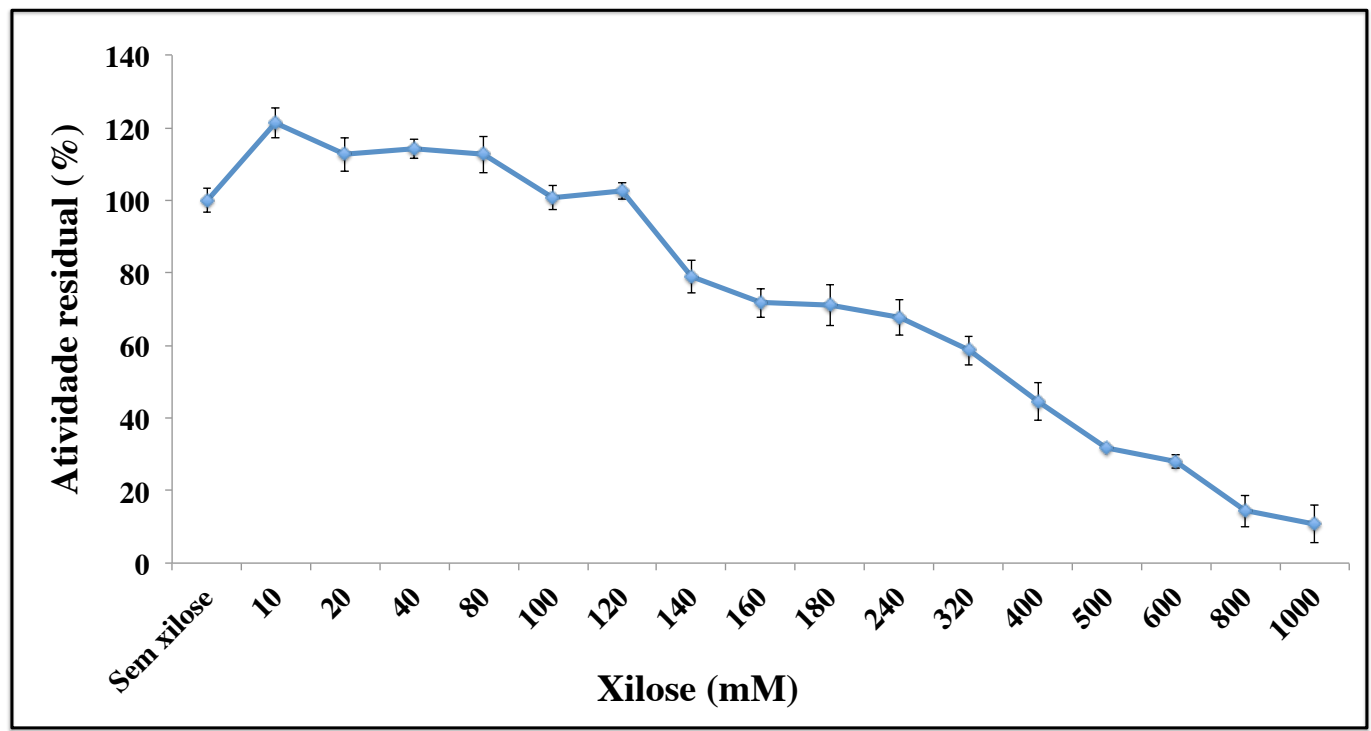

Figura 40 - Efeito da concentração de xilose sobre a atividade da HXYLA recombinante. Os valores representam a média e o desvio padrão de 4 experimentos diferentes. A dosagem da atividade foi realizada seguindo o protocolo padrão utilizando o pNPX como substrato.

Assim como observado para HXYLA, algumas $\beta$-xilosidases tem sido reportadas como tolerantes a xilose com valores de Ki acima de $290 \mathrm{mM}$ (YANG et al., 2014) ou altamente tolerantes com valores de $1000 \mathrm{mM}$ (SHI et al., 2013). Para a enzima HXYLA, foi observado que na presença de $10 \mathrm{mM}$ de xilose, a atividade da enzima aumentou até o valor máximo de $20 \%$ a mais que o controle sem a adição de xilose, e em concentrações até $80 \mathrm{mM}$ a enzima continuou sendo estimulada pela xilose (Fig. 40). 
Assim, o efeito da xilose sobre a atividade da HXYLA revelou, não só a resistência à inibição do produto final, mas que ela foi ativada por xilose em concentrações inferiores a $80 \mathrm{mM}$. O mesmo foi observado para uma $\beta$-xilosidase de Thermotoga thermarum DSM 5069 que foi estimulada por xilose até em concentrações acima de $500 \mathrm{mM}$ (SHI et al., 2013).

Para saber o tipo de inibição que a enzima HXYLA sofre pela xilose, a enzima foi submetida a incubação com $500 \mathrm{mM}$ do inibidor e a análise foi realizada pelo gráfico de Lineweaver-Burk. O resultado indicou que ocorre inibição não-competitiva, sendo determinada quando a reta intercepta o eixo-X (Fig. 41), havendo redução da velocidade máxima e o valor de Km se mantém igual ao $\mathrm{Km}$ da reação na ausência do inibidor.

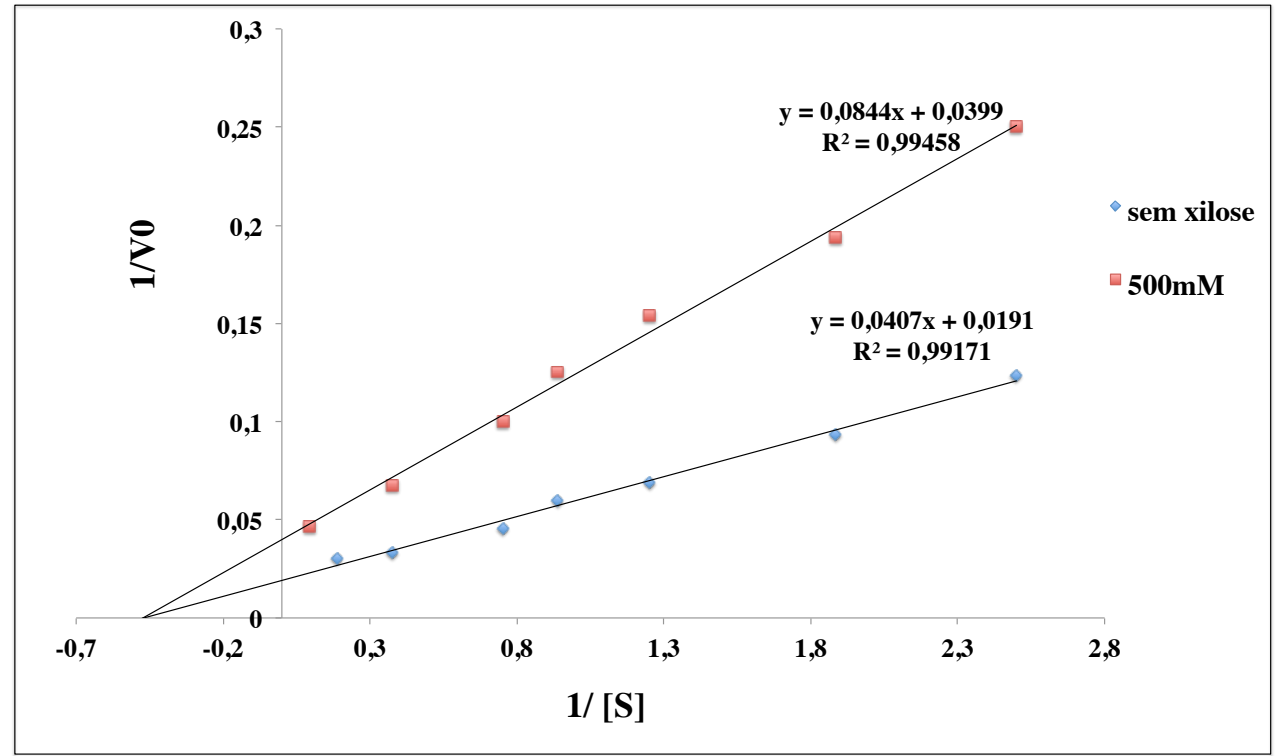

Figura 41 - Gráfico do duplo recíproco para determinar os valores de $\mathrm{Km}$ e Vmax da HXYLA na presença de $500 \mathrm{mM}$ de inibidor.

Na presença de $500 \mathrm{mM}$ de xilose variando as concentrações de substrato o valor de Vmax foi alterado de 52,3 $\mu \mathrm{mol} / \mathrm{min}$ (sem inibidor) para $25 \mu \mathrm{mol} / \mathrm{min}$ e não houve mudança significativa entre o valor de $\mathrm{Km}$ (2.11 mM com inibidor e 2,13 sem inibidor) sugerindo que a xilose atua como um inibidor não competitivo. Esse resultado é consistente com o tipo de inibição não-competitiva que ocorre quando o inibidor interfere nas propriedades catalíticas da enzima sem afetar a afinidade de ligação ao substrato. 
Esse resultado difere dos reportados para a maioria das $\beta$-xilosidases, os quais descrevem a xilose atuando como um inibidor competitivo (KIRIKYALI; WOOD; CONNERTON, 2014; SAHA, 2003; SEMENOVA et al., 2009). Em alguns casos, o inibidor se liga à enzima, dando um padrão global de inibição não competitiva (JORDAN et al., 2013). Similar ao nosso resultado, para uma $\beta$-xilosidase de $N$. crassa foi determinado que a xilose também foi inibidor não competitive, mas essa enzima apresentou um Ki baixo de 1,72 mM (KIRIKYALI; CONNERTON, 2014).

\section{4 - Ensaios de sinergismo e hidrólise do BCA.}

\subsection{1 - Avaliação do sinergismo entre HXYN2 e HXYLA na hidrólise da xilana e medula da cana-de-açúcar}

A ação sinergística entre $\beta$-xilosidases e xilanases é requerida para completa degradação da xilana em xilose (YANG et al., 2014, SUZUKI et al., 2010, RAWEESRI; RIANGRUNGROJANA; PINPHANICHAKARN, 2008). As extremidades não-redutoras dos xilooligossacarídios gerados a partir da atividade de endo-1,4- $\beta$-xilanase são hidrolisados pela ação das $\beta$-xilosidases para liberação da xilose. Assim, a produção de xilose como uma importante matéria-prima industrial é realizada cooperativamente por endo-xilanases e $\beta$-xilosidases (KOUSAR; MUSTAFA; JAMIL, 2013).

No presente trabalho, foi realizada a hidrólise da xilana beechwood, xilana oat spelt e a medula da cana-de-açúcar em reações sequenciais e simultâneas utilizando as enzimas HXYN2 e HXYLA. Para as análises de sinergismo com essas duas enzimas foi escolhido, além das xilanas purificadas, um resíduo agroindustrial (medula da cana-deaçúcar) que foi preparado por moagem sem passar por etapas de pré-tratamento prévio e com alto conteúdo de hemicelulases que, normalmente, é removida durante as etapas de pré-tratamento (GÍRIO et al., 2010). Por esse motivo, foi proposto um protocolo, com vistas a redução de custos durante a hidrólise e para previnir que a fração de hemicelulose fosse perdida.

A região dos entrenós da cana-de-açúcar pode ser dividida diagonalmente em quatro frações, das quais as duas mais internas são a medula menos recalcitrante e com menos teor de lignina e a interface moderadamente acessível medula-casca (VÁRNAI et al., 2014). É descrito na literatura que o aumento da recalcitrância da cana-de-açúcar depende das regiões do internódios e esta variedade na recalcitrância é correlacionada 
com as características microscópicas e composição química da mesma (COSTA et al., 2013).

A região da medula foi a escolhida para a hidrólise, visto que é mais digestível por enzimas hidrolíticas que as frações mais próximas da camada externa (casca). Os resultados das hidrólises são apresentados na Tabela 23. O grau de sinergismo foi definido como a razão entre o valor de liberação de xilose com as enzimas juntas pela soma da liberação de xilose pelas enzimas individuais (VAN DYK; PLETSCHKE, 2012).

Tabela 23 - Resultado da hidrólise de xilana por HXYN2 e HXYLA em reações simultâneas e sequenciais.

\begin{tabular}{|c|c|c|c|c|c|c|c|}
\hline \multicolumn{2}{|c|}{ Enzima adicionada } & \multicolumn{2}{|c|}{ Xilana Beechwood $^{1}$} & \multicolumn{2}{|c|}{ Xilana Oat spelt ${ }^{2}$} & \multicolumn{2}{|c|}{ Medula de cana-de-açúcar ${ }^{3}$} \\
\hline $1^{\text {a }}$ reação & $2^{\mathrm{a}}$ reação & $\begin{array}{c}\text { Xilose liberada } \\
(\mathrm{mg} / \mathrm{mL})\end{array}$ & Sinergismo $^{\mathrm{a}}$ & $\begin{array}{c}\text { Xilose liberada } \\
(\mathrm{mg} / \mathrm{mL})\end{array}$ & Sinergismo $^{a}$ & $\begin{array}{c}\text { Xilose liberada } \\
(\mathrm{mg} / \mathrm{mL})\end{array}$ & Sinergismo $^{a}$ \\
\hline HXYN2 & - & $1,25 \pm 0,03$ & & $1,22 \pm 0,03$ & & $0,44 \pm 0.006$ & \\
\hline HXYLA & - & $0,24 \pm 0,01$ & & $0,004 \pm 0,01$ & & $0 \pm 0$ & \\
\hline HXYN2+HXYLA & - & $1,66 \pm 0,08$ & $1,10^{*}$ & $1,70 \pm 0,04$ & $1,38^{*}$ & $0,63 \pm 0.007$ & $1,40^{*}$ \\
\hline HXYN2 & HXYLA & $1,89 \pm 0,01$ & $1,26^{*}$ & $2,39 \pm 0,008$ & $1,94^{*}$ & $0,64 \pm 0.002$ & $1,42^{*}$ \\
\hline HXYLA & HXYN2 & $1,65 \pm 0,02$ & $1,10^{*}$ & $1,67 \pm 0,022$ & $1,35^{*}$ & $0,50 \pm 0.009$ & $1,13^{*}$ \\
\hline
\end{tabular}

* diferença significativa no nível $\mathrm{p}<0,05$ (teste de $t$ de Student)

a - Sinergismo é definido como a razão de equivalentes de xilose liberados a partir de reações enzimáticas simultâneas ou sequenciais pela a soma dos equivalentes de xilose liberados pelas enzimas individuais. 1 - Xilana beechwood: 83,7\% xilose, 9,4\% de ácido glucurônico e 6,9\% outros açúcares; 2 - Xilana oat spelt: $81,4 \%$ xilose, 9,7\% arabinose e 8,9\% outros açúcares; 3 - Medula de cana-de-açúcar: $53 \%$ glicose, $16 \%$ xilose e $1,5 \%$ de arabinose.

O efeito entre duas enzimas pode variar quando elas são utilizadas simultâneamente ou sequencialmente na hidrólise de um substrato (VAN DYK; PLETSCHKE, 2012). Foi obtido um grau de sinergia de 1,10; 1,38 e 1,40 quando as enzimas foram utilizadas simultâneamente para hidrólise de xilana beechwood, oat spelt e medula de cana-de-açúcar, respectivamente. A combinação entre as enzimas HXYN2 e HXYLA liberou mais açúcares redutores em todas as reações sequenciais comparado com as reações simultâneas, mostrando sinergismo significativo na hidrólise xilana beechwood, oat spelt e medula da cana-de-açúcar (Tabela 23). Similar aos nossos resultados, a suplementação com uma $\beta$-xilosidase aumentou a liberação de açúcares redutores durante a hidrólise da xilana beechwood mais do que com uma endo-xilanase sozinha (HUY et al., 2013b). 
Os resultados das reações sequenciais mostraram que a quantidade de açúcares redutores foi aumentada para xilana beechwood e oat spelt, conferindo um grau de sinergismo de 1,26 e 1,94, respectivamente, quando a HXYN2 foi adicionada antes que a HXYLA. Quando a enzima HXYLA foi adicionada depois que a HXYN2, em reação sequencial, a quantidade de açúcares redutores liberados foi similar ao obtido nas reações simultâneas. O sinergismo com uma endo-xilanase e $\beta$-xilosidase na hidrólise da palha de milho, foi observado em reação uma simultânea com um grau de sinergismo de 1,10 (RAWEESRI; RIANGRUNGROJANA; PINPHANICHAKARN, 2008).

Similar ao ocorrido com as xilanas purificadas, a adição prévia da HXYN2 antes da HXYLA aumentou a liberação de açúcares redutores durante a hidrólise com a medula da cana-de-açúcar com um grau de sinergismo de 1,42. O grau de sinergismo obtido após hidrólise de palha de milho explodida a vapor com uma mistura de hemicelulases e uma $\beta$-xilosidase purificada de de T.reesei foi de 1,69 após 12 horas de hidrólise (HAN; CHEN, 2010).

É possível que com o aumento do tempo de hidrólise, especialmente para o resíduo lignocelulósico (medula da cana-de-açúcar), poderia aumentar a quantidade de açúcares redutores liberados. De acordo com VAN DYK \& PLETSCHKE (2012) o grau de sinergismo é também dependente das características do substrato e de outras condições experimentais, tais como a quantidade de enzima e tempo de hidrólise.

Vale ressaltar que a diferença da quantidade de açúcares redutores liberados $(\mathrm{mg} / \mathrm{mL})$ para os diferentes substratos deve-se a constituição das xilanas comerciais e de um resíduo agroindustrial. As xilanas comerciais não possuem lignina e, no caso da xilana beechwood é encontrado mais ácido glucurônico que na medula ou o bagaço de cana-de-açúcar (ASPINALL, G. O., 1959; GÍRIO et al., 2010). Ademais, a xilana beechwood é considerada uma metilglucoronoxilana, a xilana oat spelt é uma arabinoxilana e a medula ou o bagaço de cana-de-açúcar uma arabinoglucoronoxilana (GÍRIO et al., 2010).

Os produtos liberados pela hidrólise com as enzimas HXYN2 e HXYLA foram analisados por cromatografia de camada delgada (TLC), que é um método simples que provê muitas informações sobre os oligonucleotídeos liberados durante a hidrólise (Fig. 42). Em todas as reações de hidrólise onde foram utilizadas as duas enzimas, simultâneas ou sequencialmente, foram observados a liberação de xilose. A TLC é um método de deteção qualitativo, vale ressaltar que para saber as concentrações de cada 
xilooligômero se faz necessário análise por cromatografia líquida de alta eficiência (HPLC) para se obter o resultado quantitativo.

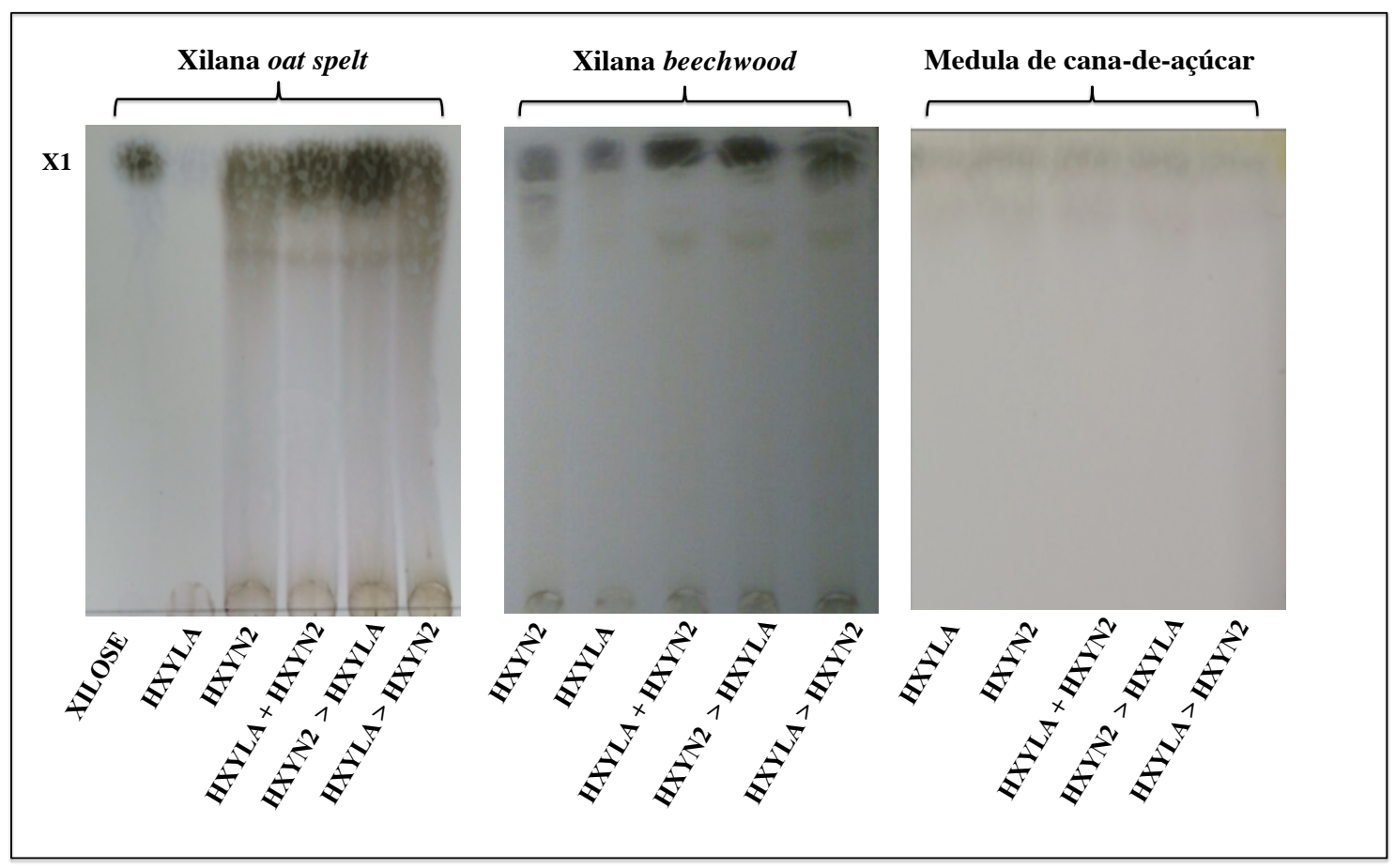

Figura 42 - Cromatografia de camada delgada feita com o hidrolisado obtido a partir de reações com HXYN2 e HXYLA. Foi aplicado $10 \mu \mathrm{l}$ de cada amostra sobre a placa de sílica.

Não foi observada liberação de xilose a partir da xilana oat spelt quando foi utilizada a enzima HXYLA sozinha porém, corroborando com os dados obtidos por ensaios de detecção de açúcares redutores por DNS, foi possível observar a liberação de xilose pela hidrólise da xilana beechwood. Não foi possível a clara visualização dos produtos liberados pela hidrólise da medula de cana-de-açúcar, visto que, a liberação de açúcares $(\mathrm{mg} / \mathrm{mL})$ foi menor que o observado para os demais substratos.

\subsection{2 - Avaliação do sinergismo entre HXYN2 e ABF3 na hidrólise da xilana}

O sinergismo entre a ABF3 e a HXYN2 na hidrólise da xilana beechwood e xilana oat spelt foi avaliado e os resultados mostraram que ocorreu sinergismo signifinificativo quanto foram utilizados as duas enzimas simultaneamente, promovendo um aumento na concentração de açúcares redutores, quando comparado com a utilização das enzimas isoladamente (Tabela 24).

Os resultados mostram que nas reações sequenciais, para a hidrólise da xilana beechwood, houve maior liberação de açúcar redutor quando a enzima HXYN2 foi adicionada antes da enzima ABF3 e, para xilana oat spelt, houve maior liberação 
quando a enzima $\mathrm{ABF} 3$ foi adicionada antes da HXYN2. Esse resultado está de acordo com a atuação das duas enzimas, visto que a $\mathrm{ABF}$ é uma enzima claramente desramificadora e que atua sobre as arabinoxilanas, estrutura encontrada justamente na xilana oat spelt (NUMAN; BHOSLE, 2006). Assim, a ABF3 permite uma melhor processividade da HXYN2. Um resultado diferente foi obtido para uma ABF de Streptomyces sp. que não foi capaz de catalizar a hidrólise da xilana oat spelt (SHI et al., 2010).

Tabela 24 - Hidrólise de xilanas comerciais por HXYN2 e ABF3 em reações simultâneas e sequenciais.

\begin{tabular}{|c|c|c|c|c|c|}
\hline \multicolumn{2}{|c|}{ Enzima adicionada } & \multicolumn{2}{|c|}{ Xilana beechwood $^{1}$} & \multicolumn{2}{|c|}{ Xilana oat spelt $^{2}$} \\
\hline Primeira reação & $\begin{array}{c}\text { Segunda } \\
\text { reação }\end{array}$ & $\begin{array}{l}\text { Liberação } \\
\text { de xilose } \\
(\mathrm{mg} / \mathrm{mL})\end{array}$ & Sinergismo $^{A}$ & $\begin{array}{l}\text { Liberação } \\
\text { de xilose } \\
(\mathrm{mg} / \mathrm{mL})\end{array}$ & Sinergismo $^{\mathrm{A}}$ \\
\hline HXYN2 & - & $1,93 \pm 0,03$ & & $1,97 \pm 0,05$ & \\
\hline ABF3 & - & $0,09 \pm 0$ & & $0,22 \pm 0,01$ & \\
\hline HXYN2+ABF3 & - & $2,24 \pm 0,03$ & $1,10 *$ & $3,06 \pm 0,06$ & $1,39 *$ \\
\hline HXYN2 & $\mathrm{ABF} 3$ & $2,20 \pm 0,02$ & $1,08 *$ & $2,92 \pm 0,06$ & $1,33 *$ \\
\hline ABF3 & HXYN2 & $1,97 \pm 0,05$ & $0,97 *$ & $3,28 \pm 0,08$ & $1,49 *$ \\
\hline
\end{tabular}

${ }^{1}$ Xilana beechwood: razão arabinose:xilose $\sim 1: 90^{2}$ Xilana oat spelt: razão arabinose:xilose $\sim$ 1:90

A - O grau sinergia é definido como a razão de equivalentes de xilose liberados pela a soma do que foi liberado pelas enzimas individuais. Os dados marcados com * significam que a reação enzimática é significativa a $\mathrm{P}<0,05$ (teste de $t$ de Student)

Uma ABF de Streptomyces sp. PC22 foi purificada e utilizada na hidrólise da xilana oat spelt e foi verificada um efeito sinérgico significativo em combinação com outras enzimas xilanolíticas, incluindo XYN, XYL e acetil esterase. Houve um aumento de 1,25 vezes na quantidade de açúcares redutores liberados em comparação com resultado para as enzimas sozinhas (RAWEESRI; RIANGRUNGROJANA; PINPHANICHAKARN, 2008).

A enzima ABF3 de $P$. purpurogenum produzida por $P$. pastoris no trabalho de Ravanal e Eyzaguirre (2010) foi utilizada em ensaios de sinergismo com uma XYN de $P$. purpurogenum na hidrólise de arabinoxilana de trigo e foi demonstrado que a ABF3 foi ativa na liberação arabinose de arabinoxilana. Ela também mostrou a atividade de xilobiohidrolase, uma vez que liberou oligossacarídeos da arabinoxilana. 


\subsection{3 - Hidrólise Enzimática do BCA Pré-tratado por explosão a vapor com as hemicelulases recombinantes: ABF3, HXYN2 e HXYLA.}

A liberação de açúcares redutores a partir da hidrólise de polissacarídeos da parede celular vegetal é necessária em muitos processos biotecnológicos e industriais, sendo que a degradação dos componentes da parede vegetal é resultado de uma série de processos bioquímos coordenados (VAN DEN BRINK; DE VRIES, 2011). A ação heterosinérgica entre enzimas xilanolíticas tem sido reportada, sendo as ABFs, XYLs e XYNs frequentemente utilizadas para hidrólise da xilana em vários processos industriais (KIRIKYALI; CONNERTON, 2015).

O aumento da eficiência dos coquetéis enzimáticos requer a ação conjunta das diferentes enzimas com atividades necessárias para a desconstrução da parede celular vegetal. Muitas destas enzimas são produzidas em baixa concentração por fungos ou bactérias. Por esse motivo, é relatado na literatura o sucesso da suplementação das misturas enzimáticas com enzimas recombinantes (ALVIRA; NEGRO; BALLESTEROS, 2011; LAOTHANACHAREON et al., 2015; SUN et al., 2015).

Os resíduos lignocelulósicos, como o BCA, são substratos interessantes para estudar o papel das enzimas acessórias na formulação de coquetéis experimentais (VÁRNAI et al., 2014). Por esse motivo, foi escolhido o BCA pré-tratado por explosão para verificação da interação das enzimas recombinantes HXYN2, ABF3 e HXYLA. O BCA pré-tratado por explosão a vapor, permitiu uma recuperação maior da fração de hemicelulose, visto que o método empregado foi mais brando, seguindo a condição de $180{ }^{\circ} \mathrm{C}$ por 5 min. $\mathrm{O}$ BCA foi quantificado quanto aos teores de açúcares presentes, apresentou os seguintes valores: 47,70 \% de glicose, 7,23\% de xilose, 2,56\% de arabinose, 1,02 \% de acetil, 31,14\% de lignina e 3,09 \% de cinzas. A quantificação foi realizada pelo grupo do Prof. Dr. Luiz Pereira Ramos da Universidade Federal do Paraná.

Por meio de planejamento experimental (DCCR) $2^{3}$ foi possível verificar que a melhor formulação contendo as três enzimas foi obtida com a menor concentração de ABF3 (Ensaio de número 13 - Tabela 25). A partir dos resultados, também foi verificado que os menores valores obtidos de liberação de açúcares redutores foram com a maior concentração da enzima ABF3, observados nos ensaios de número 6 a 8 . 
Tabela 25 - Efeito da composição da mistura enzimática composta por HXYN2, ABF3 e HXYLA para a hidrólise do BCA pré-tratado por explosão a vapor.

\begin{tabular}{ccccc}
\hline Ensaios & HXYN2 $(\mathrm{U} / \mathrm{mL})$ & HXYLA $(\mathrm{U} / \mathrm{mL})$ & ABF3 $(\mathrm{U} / \mathrm{mL})$ & $\begin{array}{c}\text { Açúcares redutores } \\
(\mathrm{mg} / \mathrm{mL})\end{array}$ \\
\hline 1 & 300 & 6 & 1 & $0,098 \pm 0,009$ \\
2 & 900 & 6 & 1 & $0,050 \pm 0,001$ \\
3 & 300 & 17 & 1 & $0,066 \pm 0,002$ \\
4 & 900 & 17 & 1 & $0,060 \pm 0,001$ \\
5 & 300 & 6 & 3 & $0,048 \pm 0,001$ \\
6 & 900 & 6 & 3 & $0,045 \pm 0,001$ \\
7 & 300 & 17 & 3 & $0,048 \pm 0,001$ \\
8 & 900 & 17 & 3 & $0,048 \pm 0,001$ \\
9 & 96 & 11,5 & 2 & $0,072 \pm 0,009$ \\
10 & 1104 & 11,5 & 2 & $0,052 \pm 0,001$ \\
11 & 600 & 2,26 & 2 & $0,051 \pm 0,001$ \\
12 & 600 & 20,74 & 2 & $0,051 \pm 0,001$ \\
13 & 600 & 11,5 & 2 & $0,130 \pm 0,016 *$ \\
14 & 600 & 11,5 & 3,68 & $0,048 \pm 0,001$ \\
15 & 600 & 11,5 & 2 & $0,060 \pm 0,004$ \\
16 & 600 & 11,5 & 2 & $0,057 \pm 0,002$ \\
17 & 600 & 11,5 & $0,059 \pm 0,003$ \\
18 & 600 & 11,5 & 2 & $0,058 \pm 0,001$ \\
19 & 600 & 11,5 & 2 & $0,057 \pm 0,002$ \\
20 & 600 & 6002 & \\
\hline
\end{tabular}

* melhor resultado obtido com a mistura das três enzimas (ABF3, HXYN2 e HXYLA)

Os resultados obtidos foram submetidos à análise estatística, inicialmente através do gráfico de Pareto que foi utilizado para comparar a liberação de açúcares redutores em todos os ensaios realizados. A linha azul indica a magnitude mínima de efeitos estatisticamente significativos para um nível de confiança de $95 \%$. O gráfico de Pareto mostra claramente que a enzima ABF3 foi a que exerceu efeito mais significativo durante a hidrólise do BCA, tanto com a maior concentração quanto com a menor concentração da enzima (Fig. 43). 


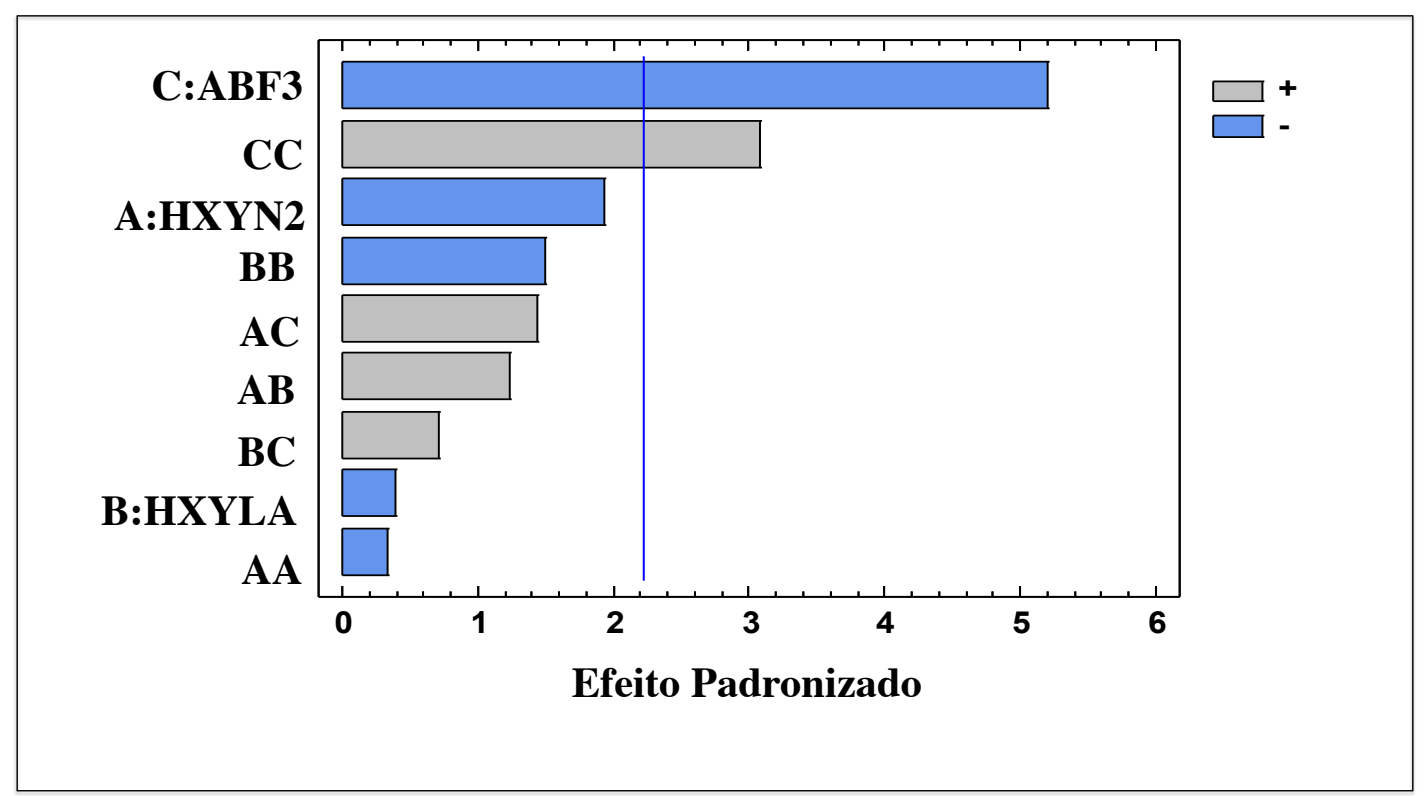

Figura 43 - Gráfico de Pareto para o efeito combinação das enzimas HXYN2, ABF3 e HXYLA para hidrólise do BCA. Valores ao lado direito da linha azul são estatisticamente significativos (95\% de confiança). A influência da interação entre os parâmetros sobre a liberação de açúcares redutores $(\mathrm{mg} / \mathrm{mL})$ do $\mathrm{BCA}$ é representada por $\mathrm{BC}, \mathrm{AB}, \mathrm{AC}$.

A fração de xilana do BCA apresenta uma estrutura de arabinoglucoronoxilana, sendo as enzimas desramificadoras importantes para permitir o acesso das enzimas que atuam na cadeia central. As arabinofuranosidases são exo-tipo atuam sobre cadeia lateral liberando o resíduo de arabinosil da cadeia principal da hemicelulose, que resulta no aumento da ação das outras enzimas, tais como as XYNs e XYLs (SAHA, 2000).

A sinergia durante a hidrólise da farinha de trigo e pectina de beterrada foi estudada utilizando XYNs, XYLs e ABFs. A degradação da cadeia principal da xilana por XYN e XYL foi influenciada mais fortemente pela ação de ABF, resultando em um aumento de 2,5 vezes na liberação de xilose (DE VRIES et al., 2000).

A partir dos resultados também foi possível realizar análise de variância segundo método de Fisher (ANOVA) apresentada na tabela 26. Na ANOVA para a liberação de açúcares redutores $(\mathrm{mg} / \mathrm{mL})$ como variável resposta, apenas a concentração da ABF3 apresentou significância durante a hidrólise do BCA. O resultado obtido pela ANOVA, está de acordo com os apresentados na análise realizada pelo método baseado na estatística $t$ de Student (gráfico de Pareto). A degradação da cadeia central da xilana por HXYN2 e HXYLA foi influenciada mais fortemente pela ação de ABF3. 
Tabela 26 - Análise de variância (ANOVA) para composição da mistura enzimática composta por HXYN2, ABF3 e HXYLA para a hidrólise do BCA pré-tratado por explosão a vapor.

\begin{tabular}{cccccc}
\hline Fonte & $\begin{array}{c}\text { Soma dos } \\
\text { quadrados }\end{array}$ & GL* & Média quadrática & $\mathrm{F}_{0}$ & Valor-P \\
\hline A:HXYN2 & 0,000586531 & 1 & 0,000586531 & 3,75 & 0,0817 \\
B:HXYLA & 0,0000240736 & 1 & 0,0000240736 & 0,15 & 0,7032 \\
C:ABF3 & 0,00423279 & 1 & 0,00423279 & 27,03 & 0,0004 \\
AA & 0,0000171875 & 1 & 0,0000171875 & 0,11 & 0,7472 \\
AB & 0,000240901 & 1 & 0,000240901 & 1,54 & 0,2431 \\
AC & 0,000326401 & 1 & 0,000326401 & 2,08 & 0,1794 \\
BB & 0,000347786 & 1 & 0,000347786 & 2,22 & 0,1670 \\
BC & 0,0000775012 & 1 & 0,0000775012 & 0,49 & 0,4978 \\
CC & 0,00148156 & 1 & 0,00148156 & 9,46 & 0,0117 \\
Erro & 0,00156573 & 10 & 0,000156573 & & \\
Total (corr.) & 0,00907937 & 19 & & & \\
* GL - grau de liberdade & & & &
\end{tabular}

O comportamento da variável de resposta frente as três enzimas avaliadas foi mostrada nos gráficos de superfie de resposta apresentados na Figura 44. Nestas figuras observa-se como o modelo se ajusta apropriadamente aos resultados experimentais e como a variável de resposta é fortemente influenciada pela concentração da ABF3.

O modelo que descreve o comportamento da interação das três enzimas para a liberação de açúcares redutores foi apresentada na equação 2 , e pode ser usado para explicar melhor os resultados da análise estatística.

Equação 2:

AR $=0,18-0,00009 *$ HXYN2 + 0,0004*HXYLA - 0,08*ABF3 - 1,21536E$8 *$ HXYN2^2 + 0,0000033*HXYN2*HXYLA + 0,00002*HXYN2*ABF3 0,00016*HXYLA^2 + 0,00056*HXYLA*ABF3 + 0,01*ABF3^2

Por meio da equação obtida foi possível construir os gráficos de superfície de resposta para liberação de açúcares redutores (Fig. 44). De acordo com o modelo obtido, o melhor resultado foi obtido para hidrólise com 600 U/mL da enzima HXYN2, 11,5 U/mL de HXYLA e 0,32 U/mL da ABF3. 


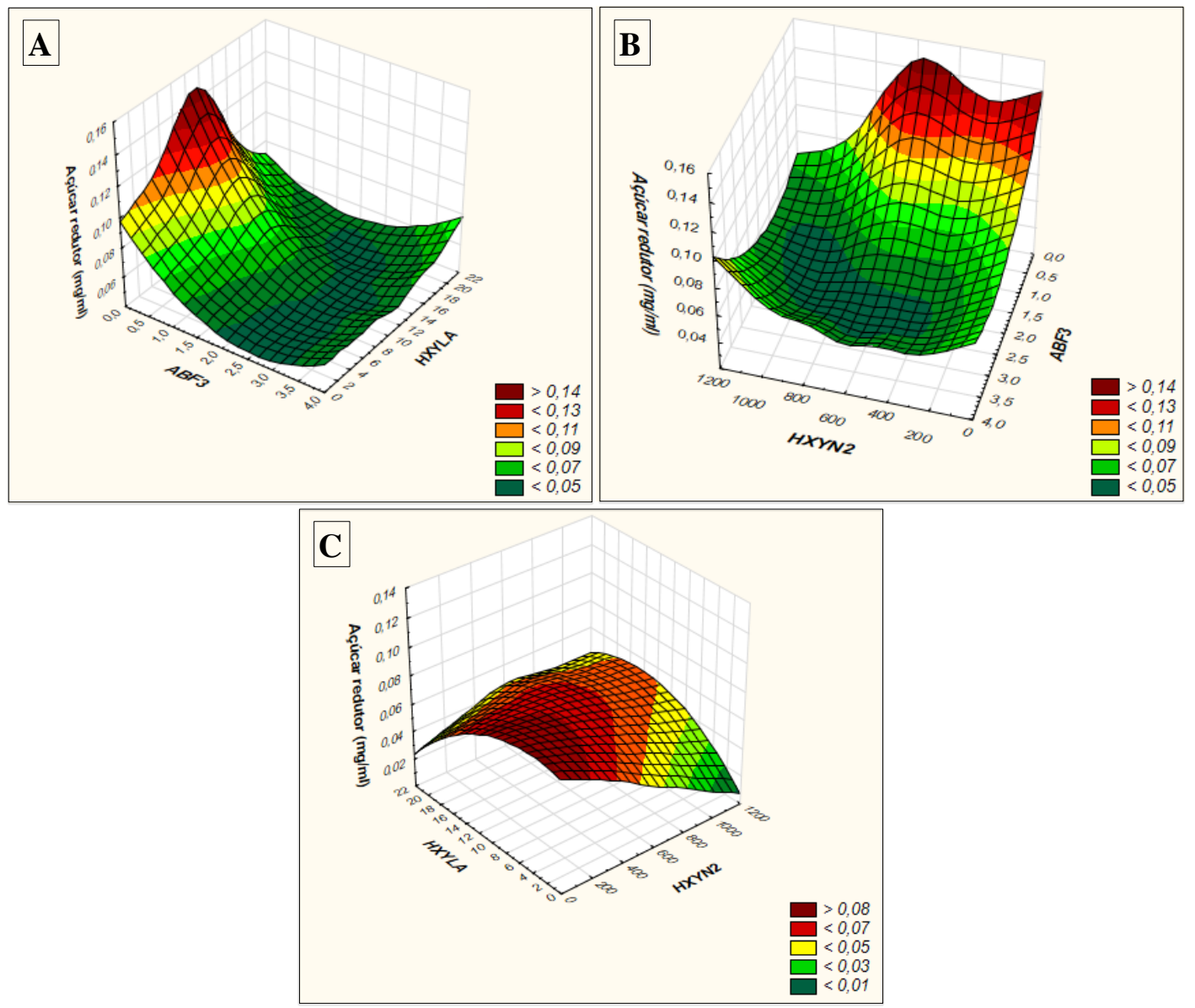

Figura 44 - Gráfico de superfície tendo como fator resposta para liberação de açúcares redutores $(\mathrm{mg} / \mathrm{mL})$ em relação às variáveis independentes: $(\mathrm{A}) \mathrm{ABF3}$ e HXYLA; (B) ABF3 e HXYN2; (C) HXYN2 e HXYLA.

A melhor proporção das enzimas obtida pelo experimento anterior (ABF3 - 0,32 $\mathrm{U} / \mathrm{mL}, \mathrm{HXYN} 2$ - $600 \mathrm{U} / \mathrm{mL}$ e HXYLA - 11,5 U/mL) foi utilizada para analisar o comportamento das enzimas quando adicionadas simultaneamente ou sequencialmente durante a hidrólise do BCA. Os resultados obtidos foram apresentados na Tabela 27.

O melhor resultado foi obtido quando a enzima ABF3 foi adicionada antes das enzimas HXYN2 e HXYLA com 0,14 U/mL (ensaio 8). Ao se realizar um teste de $\mathrm{t}$ de Student, foi observado que não houve diferença significativa entre o resultado obtido pela a hidrólise do BCA com as três enzimas simultâneas $(0,13 \mathrm{U} / \mathrm{mL})$ e com o resultado obtido com as enzimas utilizadas sequencialmente (ABF depois HXYN2 e HXYLA - 0,14 U/mL). Apesar disso, o resultado obtido com as analises das hidrólises sequenciais e simultâneas possibilita sugerir um modelo para a ação das três enzimas sobre o substrato (BCA), em que inicialmente a $\mathrm{ABF} 3$ estaria agindo sobre a hemicelulose, em seguida a HXYN2 e por último a HXYLA. 
Os resultados obtidos por RAHMAN e colaboradores (2003), também sugerem que estas enzimas hidrolisam sequencialmente a hemicelulose na seguinte ordem: a-Larabinofuranosidase $->$ endo-xilanase $->\beta$-xilosidase, o que corrobora com os nossos resultados, que sugerem que a degradação efetiva do BCA pode ser obtida com quando uma enzima desramificadora atua antes de hidrólise com as enzimas que atuam na cadeia central.

Tabela 27 - Efeito da suplementação sequencial e simultânea das enzimas HXYN2, ABF3 e HXYLA na hidrólise do BCA pré-tratado por explosão a vapor.

\begin{tabular}{|c|c|c|c|c|c|c|}
\hline \multicolumn{3}{|c|}{ Enzimas adicionadas na reação } & \multicolumn{3}{|c|}{ Enzimas (U/mL) } & \multirow{2}{*}{$\begin{array}{l}\text { Açúcares } \\
\text { redutores } \\
(\mathrm{mg} / \mathrm{mL})\end{array}$} \\
\hline & $1^{\mathrm{a}}$ reação & $2^{\mathrm{a}}$ reação & ABF3 & HXYN2 & HXYLA & \\
\hline 1 & ABF3 & & 0,32 & & & 0,048 \\
\hline 2 & HXYN2 & & & 600 & & 0,107 \\
\hline 3 & HXYLA & & & & 11,5 & 0,010 \\
\hline 4 & ABF3 + HXYN2 & & 0,32 & 600 & & 0,123 \\
\hline 5 & HXYN2 + HXYLA & & & 600 & 11,5 & 0,120 \\
\hline 6 & HXYLA + ABF3 & & 0,32 & & 11,5 & 0,049 \\
\hline 7 & $\begin{array}{c}\text { ABF3 + HXYN2 + } \\
\text { HXYLA }\end{array}$ & & 0,32 & 600 & 11,5 & $0,130 *$ \\
\hline 8 & $\mathrm{ABF} 3$ & HXYN2 + HXYLA & 0,32 & 600 & 11,5 & $0,140 *$ \\
\hline 9 & $\mathrm{ABF} 3$ & HXYN2 & 0,32 & 600 & & 0,092 \\
\hline 10 & $\mathrm{ABF} 3$ & HXYLA & 0,32 & & 11,5 & 0,076 \\
\hline 11 & HXYN2 & ABF3 + HXYLA & 0,32 & 600 & 11,5 & 0,118 \\
\hline 12 & HXYN2 & ABF3 & 0,32 & 600 & & 0,065 \\
\hline 13 & HXYN2 & HXYLA & & 600 & 11,5 & 0,130 \\
\hline 14 & HXYLA & $\mathrm{ABF} 3+\mathrm{HXYN} 2$ & 0,32 & 600 & 11,5 & 0,053 \\
\hline 15 & HXYLA & ABF3 & 0,32 & & 11,5 & 0,029 \\
\hline 16 & HXYLA & HXYN2 & & 600 & 11,5 & 0,071 \\
\hline 17 & HXYN2 + ABF & HXYLA & 0,32 & 600 & 11,5 & 0,110 \\
\hline 18 & HXYN2 + HXYLA & ABF3 & 0,32 & 600 & 11,5 & 0,129 \\
\hline 19 & ABF3 + HXYLA & HXYN2 & 0,32 & 600 & 11,5 & 0,076 \\
\hline
\end{tabular}

* Não houve direfença significativa ao nível de $P>0,05$ entre o resultado obtido com as enzimas durante a hidrólise sequencial e simultânea.

Durante as etapas de pré-tratamento, uma parte da hemicelulose pode ser removida, no entanto parte da parcela de arabinose pode permanecer ligada a xilana ou nos xilooligômeros. Já é sabido que as ABFs ajudam a remover os resíduos de arabinose, favorecendo a desrramificação. Além disso, elas colaboram com remoção da ligação lignina-carboidratos, uma vez que os resíduos de arabinose participam dessa interação hemicelulose-lignina por meio de ligações éter com o ácido ferúlico e lignina (SUN et al., 2005). 
$\mathrm{O}$ efeito pode ser explicado visto que as $\mathrm{ABFs}$ removem os resíduos de arabinose ligados a cadeia central da xilana, abrindo mais sítios para ligação das endoxilanases. As moléculas de arabinose podem bloquear o acesso a ligações $\beta-1,4$ na cadeia da xilana (RAWEESRI; RIANGRUNGROJANA; PINPHANICHAKARN, 2008).

Vale ressaltar que as hidrólises foram realizadas em pH 5,0 e a $50{ }^{\circ} \mathrm{C}$, que são os parâmetros ótimos para a enzima $\mathrm{HXYN} 2$ e $\mathrm{ABF}$, mas nesse $\mathrm{pH}$ e temperatura a enzima HXYLA reteve menos que $40 \%$ e $20 \%$ da atividade após $48 \mathrm{~h}$, respectivamente. Sugerimos que experimentos analisando essas variáveis, $\mathrm{pH}$ e temperatura ótima para a hidrólise, se fazem necessárias para otimizar o rendimento da hidrólise do BCA. A tabela 28 mostra as características bioquímicas das enzimas recombinantes HXYN2, ABF3 e HXYLA.

Tabela 28 - Características bioquímicas das enzimas recombinantes HXYN2, ABF3 e HXYLA.

\begin{tabular}{|c|c|c|c|}
\hline & HXYN2 & ABF3 & HXYLA \\
\hline Função & Endo-xilanase & $\begin{array}{c}\text { Arabinofuranosidas } \\
\text { e/xilosidase }\end{array}$ & $\begin{array}{c}\text { Xilosidase/ } \\
\text { arabinofuranosidase }\end{array}$ \\
\hline Família GH & GH11 & GH43 & GH43 \\
\hline pH ótimo & 6,5 & 5,0 & 7,0 \\
\hline Temperatura ótima & $60^{\circ} \mathrm{C}$ & $50^{\circ} \mathrm{C}$ & $50^{\circ} \mathrm{C}$ \\
\hline Atividade ótima em pH 5,0 e $50^{\circ} \mathrm{C}$ & 4500 U.mg ${ }^{-1}$ & $\begin{array}{c}0,5 \mathrm{U} \cdot \mathrm{mg}^{-1} / \\
0,5 \mathrm{U} \cdot \mathrm{mg}^{-1}\end{array}$ & $\begin{array}{l}28 \mathrm{U} \cdot \mathrm{mg}^{-1} / \\
13,5 \mathrm{U} \cdot \mathrm{mg}^{-1}\end{array}$ \\
\hline Termoestabilidade em pH 5,0 & $\begin{array}{c}\text { retenção de } 95 \\
\% \text { até } 48 \mathrm{~h}\end{array}$ & $\begin{array}{c}\text { retenção de } 95 \% \\
\text { até } 48 \mathrm{~h}\end{array}$ & $\begin{array}{c}\text { retenção de } 40 \% \\
\text { até } 48 \mathrm{~h}\end{array}$ \\
\hline Termoestabilidade a $50^{\circ} \mathrm{C}$ & $\begin{array}{c}\text { retenção de } 65 \\
\% \text { até } 48 \mathrm{~h}\end{array}$ & $\begin{array}{c}\text { retenção de } 25 \% \\
\text { até } 48 \mathrm{~h}\end{array}$ & $\begin{array}{c}\text { retenção de } 20 \% \\
\text { até } 48 \mathrm{~h}\end{array}$ \\
\hline
\end{tabular}

\subsection{3 - Avaliação da suplementação do preparado comercial Accellerase 1500} (DuPont) com hemicelulases para hidrólise do BCA.

A hidrólise da celulose é dificultada pela sua interação fisica com a hemicelulose e lignina. Logo, uma mistura enzimática contendo diferentes enzimas envolvidas na hidrólise de cada parte da estrutura lignocelulósica é crucial para aumentar os rendimentos da hidrólise enzimática (VAN DYK; PLETSCHKE, 2012). A hidrólise eficiente da fração de hemicelulose poderia ter um efeito sinérgico por aumentar a acessibilidade de celulases às fibras de celulose e melhorar o processo de hidrólise enzimática, tornando possível uma redução das cargas de enzimas utilizadas durante esse processo em escala industrial. Pesquisas recentes sugerem que as hemiceluloses, em particular sob a forma de xilana e seus oligómeros, podem inibir à 
atividade das celulases. A remoção de hemiceluloses ou eliminação dos seus efeitos negativos pode, por conseguinte, tornar-se crucial para a realização da conversão de celulose a glicose (QING; WYMAN, 2011; ZHANG; TANG; VIIKARI, 2012).

Até mesmo uma baixa quantidade de xilana residual pode limitar a extensão e a taxa de hidrólise da celulose. Tem sido relatado por diversos autores que a suplementação dos coquetéis de celulases com xilanases claramente aumentam a hidrólise da celulose em materiais lignocelulósicos contendo xilana (SELIG et al., 2008; SHARMA et al., 2016b; SUN et al., 2015; ZHANG et al., 2011b).

Com esse objetivo, foi proposta uma análise com a mistura composta pelas hemicelulases ABF3, HXYN2 e HXYLA para suplementação da celulase comercial Accelerase 1500 (DuPont) durante a hidrólise do BCA. Foi utilizada a melhor formulação com as três hemicelulases obtida pelo ensaio de número 13 do DCCR (HXYN2 - $600 \mathrm{U} / \mathrm{mL}$; ABF3 0,32 U/mL; HXYLA 11,5 U/mL) e a Accelerase (ACR) na concentracão de $5 \mathrm{FPU} / \mathrm{g}$ de substrato, seguindo protocolo descrito por ALVIRA e colaboradores (2011). A suplementação com as hemicelulases aumentou a liberação de glicose a partir da hidrólise do BCA, o que mostrou a capacidade destas enzimas de melhorar a digestibilidade de celulose e tornar o processo de hidrólise mais eficiente (Fig. 45).

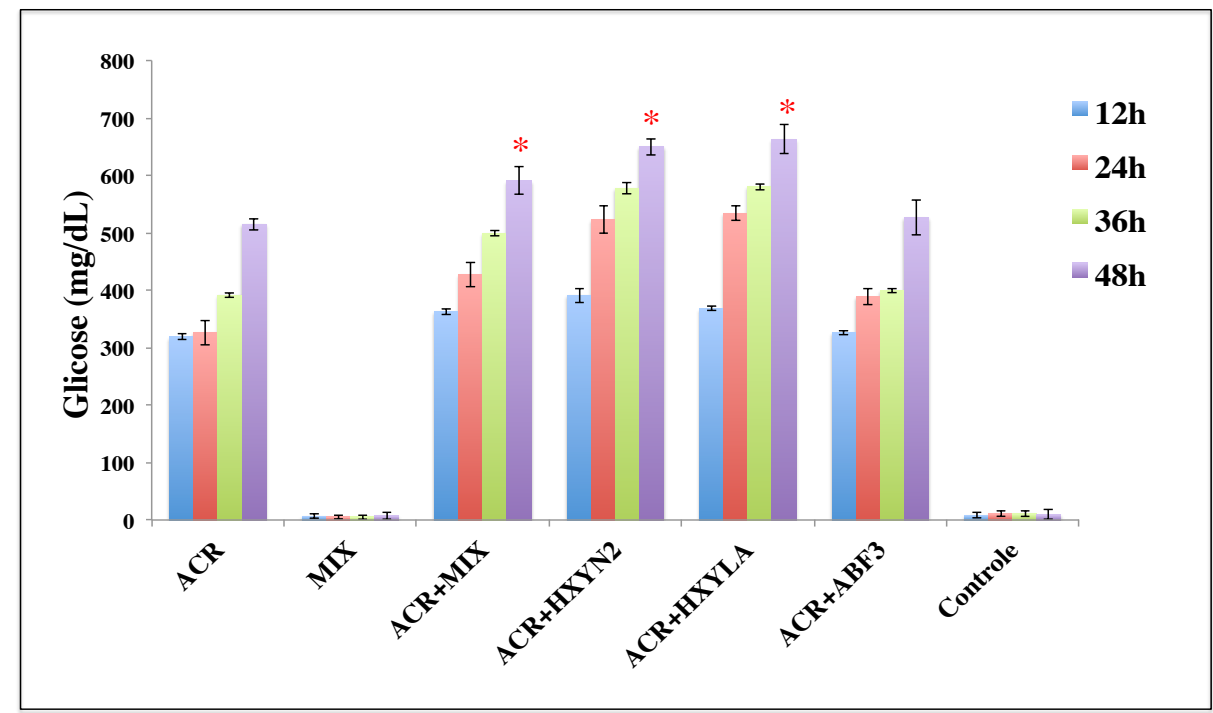

Figura 45 - Efeito da suplementação de Accelerase ${ }^{\circledR}$ (ACR) com as hemicelulases recombinantes (HXYN2 - $600 \mathrm{U} / \mathrm{mL}$; ABF3 - 0,32 U/mL; HXYLA - 11,5 U/mL) durante a hidrólise de BCA pré-tratado por explosão a vapor. A hidrólise foi realizada com a mistura enzimática contendo as três enzimas, bem como as enzimas isoladas para a suplementação de ACR (5 FPU/g de substrato). A hidrólise ocorreu por 48 h, $50{ }^{\circ} \mathrm{C}$, pH 5,0, $140 \mathrm{rpm}$. Os dados marcados com $*$ significam que houve diferença significativa a $P<0,05$ (Teste de $t$ ). 
O resultado obtido com a hidrólise enzimática do BCA com apenas a mistura de hemicelulases (Coquetel), mostrou que não houve liberação de glicose porém, com a adição da mistura de hemicelulases ao ACR foi possível observar um aumento gradual até 48 h, culminando em 14,6\% a mais de glicose como produto final. Pelo teste de $t$, foi possível analisar que houve diferença significativa entre a hidrólise com apenas a ACR e para a hidrólise com a suplementação com o Coquetel e as enzimas HXYN2 e HXYLA. Não houve diferença significativa no resultado apresentado pela suplementação de ACR apenas com a enzima ABF3 (Fig. 45).

Durante a hidrólise de outro substrato lignocelulósico, a palha de trigo, foi observado que a suplementação com uma XYN e uma ABF em combinação com celulases comerciais (ACR e Cellic - Novozymes) aumentou em 10\% o rendimento da hidrólise. Esse dado mostra o potencial apresentado pelas enzimas recombinantes para melhorar a hidrólise enzimática e tornando todo o processo mais eficaz (ALVIRA; NEGRO; BALLESTEROS, 2011).

Um resultado interessante foi obtido com a hidrólise com ACR suplementada apenas com a enzima HXYN2 ou com a enzima HXYLA onde foi obtido um aumento da produção de glicose de $26 \%$ e $29 \%$, respectivamente. Esse rendimento foi maior que o obtido com a suplementação com a mistura das três enzimas simultaneamente.

Dados da literatura apontam que a xilose, especificamente, os xilooligômeros solúveis liberados a partir da hemicelulose durante a hidrólise enzimática, apresentam uma importante barreira à ação das celulases por inibição competitiva a atividade das celulases (QING; YANG; WYMAN, 2010). Por esse motivo, é importante a suplementação com XYNs e XYLs, visto que a remoção química ou enzimática da xilana e xilooligômeros antes da adição de celulases proporciona um método particularmente importante de aumentar a eficácia das celulases e reduzindo a inibição e e melhorando o desempenho da hidrólise (QING; WYMAN, 2011).

Em trabalho realizado por QING e WYMAN (2011), foi verificado que a adição de hemicelulases várias horas antes da adição de celulases, em hidrólise sequencial, foi mais benéfico do que a adição posterior das enzimas durante a hidrólise de palha de milho, possivelmente, como resultado de uma maior afinidade de adsorção de celulase e xilanase a xilana que a celulose.

Com base nesse dado, foi realizada uma análise utilizando a ACR com o coquetel de hemicelulases recombinantes (ABF3, HXYN2 e HXYLA) em hidrólises sequênciais. Os experimentos foram realizados conforme descrito no item 5.29.3. O 
resultado é apresentado na Figura 46 e representa a dosagem de liberação de glicose a partir da hidrólise do BCA após $48 \mathrm{~h}$ a $50{ }^{\circ} \mathrm{C}$. Foi possível observar que a realização de uma hidrólise prévia (por $48 \mathrm{~h}$ a $50{ }^{\circ} \mathrm{C}$ ) com o coquetel de hemicelulases (ABF3, HXYN2 e HXYLA) antes da hidrólise com a ACR aumentou o rendimento de liberação de glicose em $50 \%$ comparado com a liberação de glicose durante a hidrólise apenas com a ACR.

A liberação de glicose a partir da hidrólise prévia com a ACR atuando antes da hidrólise com o coquetel de hemicelulases não apresentou diferença significativa com a liberação de glicose a partir da hidrólise da ACR atuando sozinha, mostrando que o coquetel de hemicelulases não é capaz de liberar glicose a partir do substrato (BCA) e corroborando com o observado para a hidrólise com apenas o coquetel de hemicelulases mostrado no resultado da Figura 45.

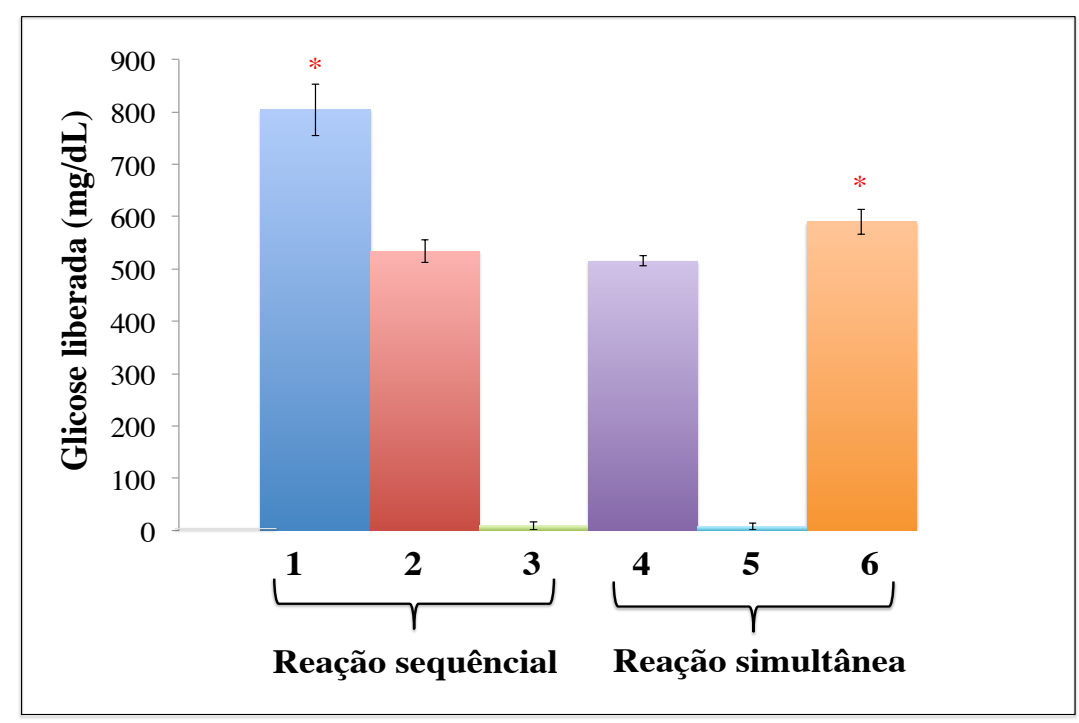

Figura 46 - Efeito da adição prévia com o coquetel de hemicelulases recombinantes (HXYN2 - 600U/mL; ABF3 - 0,32 U/mL; HXYLA - 11,5 U/mL) antes da adição da Accelerase ${ }^{\circledR}(\mathrm{ACR})$ durante a hidrólise de BCA pré-tratado por explosão a vapor. A primeira hidrólise da reação sequencial ocorreu por $48 \mathrm{~h}, 50{ }^{\circ} \mathrm{C}, \mathrm{pH} 5,0,140 \mathrm{rpm}$. Após a inativação da primeira mistura enzimática (ACR ou coquetel de hemicelulases), foi adicionada a segunda mistura enzimática (ACR ou coquetel de hemicelulases) para nova hidrólise seguindo as mesmas condições da anterior. 1 - Coquetel de hemicelulases adicionado $48 \mathrm{~h}$ antes da adição de ACR. 2 - ACR adicionada $48 \mathrm{~h}$ antes da adição do Coquetel. Controles: $\mathbf{3}$ - sem adição de enzima. 4 - Hidrólise por 48 h com ACR. 5 - Hidrólise por 48 h com o Coquetel de hemicelulases. 6 - Hidrólise por 48 h com ACR e Coquetel de hemicelulases em reação simultânea. Os dados marcados com $*$ significam que houve diferença significativa a $P<0,05$ (Teste de $t$ ).

O resumo dos resultados obtidos com a suplementação da mistura comercial de celulases (ACR) com o coquetel de hemicelulases recombinantes está apresentado na Tabela 29. 
Tabela 29 - Resultado da hidrólise do bagaço de cana-de-açúcar com as hemicelulases recombinantes e Accelerase ${ }^{\circledR}$ (ACR) em reações simultâneas e sequenciais.

\begin{tabular}{ccc}
\hline \multicolumn{2}{c}{ Enzima adicionada } & Hidrólise do BCA \\
\hline Primeira reação & $\begin{array}{c}\text { Segunda reação } \\
\left(48 \mathrm{~h}, 50^{\circ} \mathrm{C}, \mathrm{pH} 5,0,140 \mathrm{rpm}\right)\end{array}$ & $\begin{array}{c}\text { Liberação de glicose } \\
(\mathrm{mg} / \mathrm{dL})\end{array}$ \\
\hline ACR & - & $515,0 \pm 9,9$ \\
Coquetel & $\left.{ }^{\circ} \mathrm{C}, \mathrm{pH} 5,0,140 \mathrm{rpm}\right)$ & $7,4 \pm 6,0$ \\
ACR + Coquetel & - & $590,5 \pm 24,3 *$ \\
ACR + HXYN2 & - & $649,7 \pm 14,3 *$ \\
ACR + HXYLA & - & $663,2 \pm 25,5 *$ \\
ACR + ABF3 & - & $525,9 \pm 30,2$ \\
ACR & - & $533,9 \pm 21,9$ \\
Coquetel & Coquetel & $804,2 \pm 49 *$ \\
\hline
\end{tabular}

Os dados marcados com $*$ significam que a hidrólise foi significativa a $\mathrm{P}<0,05$ (teste de $t$ de Student). Os resultados foram comparados com a média obtida pela hidrólise com a ACR durante 48 h $(515,0$ $\mathrm{mg} / \mathrm{dL} \pm 9,9)$.

Portanto, alcançar a hidrólise eficiente das hemiceluloses da parede celular vegetal representa uma meta importante e lucrativa para os biotecnólogos. Além disso, os estudos sobre os efeitos sinérgicos das hemicelulases com enzimas comerciais, podem conduzir a uma melhoria de muitos produtos industriais existentes. 


\section{Gonclusiões}




\section{7- CONCLUSÕES}

As hemicelulases recombinantes HXYN2, ABF3 e HXYLA foram produzidas em P. pastoris e utilizadas para hidrólise do BCA pré-tratado por explosão a vapor, sendo possível estabelecer uma mistura capaz de realizar a conversão da fração residual de xilana do BCA em xilose, sendo a bioconversão eficiente da fração de xilana do BCA uma etapa imprescindível para o aproveitamento da xilose. A enzima que exerceu efeito mais significativo durante o processo da hidrólise foi a $\mathrm{ABF} 3$, tanto com a maior concentração quanto com a menor concentração da enzima. Esse resultado pode ser explicado pelo fato de as ABFs removerem os resíduos de arabinose ligados a cadeia central da xilana, abrindo mais sítios para ligação das endo-xilanases e consequentemente para a atuação das $\beta$-xilosidases.

O comportamento das hemicelulases quando adicionadas simultaneamente ou sequencialmente durante a hidrólise do BCA foi analisado, sendo possível estabelecer um modelo para atuação dessas enzimas sobre o BCA. Os resultados sugerem que a degradação efetiva do BCA pode ser obtida quando uma enzima desramificadora atua antes da hidrólise com as enzimas que agem na cadeia central, logo a ordem para atuação das enzimas é: $\alpha$-L-arabinofuranosidase $->$ endo-xilanase $->\beta$-xilosidase.

Outro resultado importante foi o sucesso da suplementação de celulases comerciais com o coquetel de enzimas recombinantes produzidas no presente trabalho. Nossos resultados mostram o potencial de atividades acessórias para aumentar a hidrólise enzimática, tais como XYNs, ABFs e XYLs, que estão ausentes ou presentes em pequenas proporções nas celulases comerciais.

Os principais resultados obtidos foram:

1. A endo-xilanase HXYN2 foi produzida com sucesso por P. pastoris com atividade total de $270 \mathrm{U} / \mathrm{ml}$. A enzima foi secretada na forma ativa e foi possível estabelecer um protocolo para purificação da mesma por cromatografia de exclusão de peso molecular.

2. O cDNA do gene da arabinofuranosidase/ $\beta$-xilosidase (ABF3) de $P$. purpurogenum foi transformado em duas linhagens de P.pastoris, sendo possível a produção da enzima pela levedura. A linhagem GS115 foi melhor para produção da ABF3 que a linhagem SMD1168. 
A enzima apresentou $\mathrm{pH}$ e temperatura ótima de 5,0 e $50{ }^{\circ} \mathrm{C}$, respectivamente.

3. A partir da alta identidade e similaridade entre genes de H. grisea e $H$. insolens, foi possível o desenho de oligonucleotídeos com base em sequências depositadas em banco de dados, para amplificação de genes de duas $\beta$-xilosidases de H. grisea (HXYLA e HXYLB).

4. Os cDNAs dos genes das duas $\beta$-xilosidases foi amplificado e utilizado para a clonagem em vetores de expressão para $P$. pastoris. Foram utilizados os vetores pPIC9 e pHIL-D2. Não foi possível observar diferença entre o perfil de proteínas secretadas pelos transformantes produtores de HXYLA e HXYLB obtidos com a construção utilizando o vetor pPIC9 e os controles.

5. A enzima HXYLA foi produzida com sucesso por P. pastoris nas linhagens GS115 e SMD1168 e utilizando o vetor de expressão pHILD2. Sendo a melhor para a produção da enzima HXYLA a linhagem protease (-) SMD1168. Além disso, dois fenótipos de P. pastoris foram utilizados para produção: $\mathrm{Mut}^{+} \mathrm{e} \mathrm{Mut}^{\mathrm{s}}$. O melhor produtor foi obtido com o fenótipo $\mathrm{Mut}^{+}$.

6. Foi realizada a otimização da produção de HXYLA por meio de planejamento experimental $2^{3}$, onde foi possível observar que o parâmetro mais significativo foi a concentração de metanol, enquanto as concentrações de fonte de nitrogênio e densidade celular inicial não foram significativos.

7. A enzima HXYLA foi purificada em um único passo por cromatografia de exclusão molecular, foi possível detectar a atividade de uma única banda no zimograma, que corresponde a HXYLA. A enzima apresentou $37 \mathrm{kDa}, \mathrm{pH}$ e temperatura ótima de 7,0 e $50{ }^{\circ} \mathrm{C}$, respectivamente. A enzima foi caracterizada como bifuncional, apresentando atividade de $\beta$-xilosidase e arabinofuranosidase. $\mathrm{O}$ valor de $\mathrm{Km}$ e Vmax foram de $2,13 \mathrm{mM}$ e $52,35 \mu \mathrm{mol} / \mathrm{min} / \mathrm{mg}$, respectivamente. A HXYLA apresentou elevada tolerância a xilose com um valor de $\mathrm{K} i$ de $350 \mathrm{mM}$. Foi determinado que a xilose é um inibidor não-competivivo. 
8. As enzimas HXYLA e HXYN2 foram utilizadas simultâneas e sequencialmente na hidrólise de xilana beechwood, oat spelt e medula de cana-de-açúcar. Durante a hidrólise de 12 horas, as quantidades de açúcares redutores liberados na presença das duas enzimas foram cerca de 1,$10 ; 1,38$ e 1,40 vezes maior para xilana de beechwood, oat spelt e medula cana-de-açúcar em comparação com os valores esperados para as enzimas individuais agindo sozinhas. O maior grau de sinergia por reações sequenciais foi obtido com a HXYN2 antes da HXYLA.

9. As enzimas ABF3 e HXYN2 também foram utilizadas com sucesso na hidrólise da xilana beechwood e oat spelt. O melhor resultado obtido para a xilana beechwood foi com as duas enzimas agindo simultaneamente, com um grau de sinergismo de 1,10. Para a hidrólise da xilana oat spelt o melhor resultado foi obtido em reações sequenciais com a ABF3 agindo antes da HXYN2 com um grau de sinergismo de 1,49 .

10. Por meio de planejamento experimental, foi possível detectar a melhor formulação enzimática contendo as três hemicelulases produzidas para hidrólise da fração residual de xilana do BCA prétratado por explosão a vapor. Foi observado que a ABF3 é a enzima que exerce efeito significativo sobre a hidrólise, sendo que a sua adição prévia aumentou em $8 \%$ a hidrólise e liberação de açúcares redutores.

11. A suplementação de celulases comerciais com as hemicelulases recombinantes produzidas por $P$. pastoris durante a hidrólise do BCA mostrou que a mistura contendo as três enzimas aumentou a hidrólise (liberação de glicose) em $15 \%$. Enquanto a adição prévia das hemicelulases na hidrólise, aumentou o redimento da hidrólise (liberação de glicose) em $50 \%$. 
Perspectivas 


\section{8-PERSPECTIVAS}

As sugestões para a continuidade do trabalho são apresentadas a seguir:

1. Sugerimos a realização da otimização da produção de HXYLB por $P$. pastoris para melhorar a produção e, consequentemente, facilitar a purificação da enzima para posterior caracterização enzimática.

2. A produção de enzimas em escala de biorreator tem sido descrita em muitos trabalhos, onde tem sido observado que os transformantes $\mathrm{Mut}^{\mathrm{S}}$ se adapatam melhor do que os $\mathrm{Mut}^{+}$, justamente por não apresentarem crescimento acelerado. Em função disso, sugerimos a realização da otimização da produção de HXYLA pelo transformante T24 (SMD1168/Mut ${ }^{\mathrm{S}}$ ). Vários outros estudos podem ser realizados no sentido de comparar a produção da enzima recombinante pelos dois trasnformantes com fenótipos diferentes.

3. Apesar da produção da enzima HXYLA mesmo em pequena escala, se faz necessário novos estudos com fermentação em biorreatores para otimização da produção da enzima para aplicação em escala comercial.

4. Propomos também, a realização de novos testes de hidrólise do BCA a fim de se minimizar a quantidade de enzimas utilizadas nos ensaios de suplementação de hemicelulases e celulases.

5. Além dessas propostas, é possível realizar estudos biofísicos estruturais da enzima HXYLA, visto que até o presente momento, nenhuma $\beta$-xilosidase fúngica da família GH43 teve sua estrutura cristalizada e elucidada.

6. A compreensão de como as enzimas produzidas nesse trabalho interagem e agem sobre a lignocelulose e a relação entre estrutura e função em nível molecular são outros aspectos que precisam ser estudados. 
Referêncivas

bibliográficass 


\section{REFERÊNCIAS BIBLIOGRÁFICAS}

AACHARY, A. A.; PRAPULLA, S. G. Xylooligosaccharides (XOS) as an emerging prebiotic: microbial synthesis, utilization, structural characterization, bioactive properties, and applications. Comprehensive Reviews in Food Science and Food Safety, v. 10, n. 1, p. 2-16, 2011.

AGBOR, V. B. et al. Biomass pretreatment: Fundamentals toward application. Biotechnology Advances, v. 29, n. 6, p. 675-685, nov. 2011.

AHMAD, M. et al. Protein expression in Pichia pastoris: recent achievements and perspectives for heterologous protein production. Applied microbiology and biotechnology, v. 98, n. 12, p. 5301-5317, 2014.

AKADA, R.; MURAKANE, T.; NISHIZAWA, Y. DNA extraction method for screening yeast clones by PCR. Biotechniques, v. 28, n. 4, p. 668-70, 2000.

ÁLVAREZ-CERVANTES, J. et al. Phylogenetic analysis of $\beta$-xylanase SRXL1 of Sporisorium reilianum and its relationship with families (GH10 and GH11) of Ascomycetes and Basidiomycetes. Scientific Reports, v. 6, 2016.

ALVIRA, P.; NEGRO, M. J.; BALLESTEROS, M. Effect of endoxylanase and $\alpha$-Larabinofuranosidase supplementation on the enzymatic hydrolysis of steam exploded wheat straw. Bioresource technology, v. 102, n. 6, p. 4552-4558, 2011.

AMORE, A. et al. A family GH51 $\alpha$-L-arabinofuranosidase from Pleurotus ostreatus: identification, recombinant expression and characterization. Applied microbiology and biotechnology, v. 94, n. 4, p. 995-1006, 2012.

ARANTES, V.; SADDLER, J. N. Cellulose accessibility limits the effectiveness of minimum cellulase loading on the efficient hydrolysis of pretreated lignocellulosic substrates. Biotechnology for Biofuels, v. 4, n. 1, p. 1-17, 2011.

ARORA, R.; BEHERA, S.; KUMAR, S. Bioprospecting thermophilic/thermotolerant microbes for production of lignocellulosic ethanol: A future perspective. Renewable and Sustainable Energy Reviews, v. 51, p. 699-717, 2015. 
ASPINALL, G. O. Structural chemistry of the hemicelluloses. v. 14, p. 429-68, 1959.

BASTOS, F. M. Expressão heteróloga do gene Hxyn2 do fungo Humicola grisea var. thermoidea em Pichia pastoris: Produção e purificação da enzima HXYN2r e aplicação em testes de panificação. Dissertação (Mestrado em Biologia)-Goiânia, Goiás: Universidade Federal de Goiás, Mai 2008.

BEAUGRAND, J. et al. Impact and efficiency of GH10 and GH11 thermostable endoxylanases on wheat bran and alkali-extractable arabinoxylans. Carbohydrate research, v. 339, n. 15, p. 2529-2540, 2004.

BELDMAN, G. et al. Arabinans and arabinan degrading enzymes. Adv. Macromol. Carbohydr. Res, v. 1, n. 1, p. 64, 1997.

BENASSI, V. M. et al. Immobilization and biochemical properties of a $\beta$-xylosidase activated by glucose/xylose from Aspergillus niger USP-67 with transxylosylation activity. Journal of Molecular Catalysis B: Enzymatic, v. 89, p. 93-101, maio 2013.

BENOLIEL, B. et al. Expression of a Glucose-tolerant $\beta$-glucosidase from Humicola grisea var. thermoidea in Saccharomyces cerevisiae. Applied Biochemistry and Biotechnology, v. 160, n. 7, p. 2036-2044, 1 abr. 2010.

BERLIN, A. et al. Optimization of enzyme complexes for lignocellulose hydrolysis. Biotechnology and Bioengineering, v. 97, n. 2, p. 287-296, 2007.

BHATTACHARYYA, S. et al. Purification and Characterization of an Extracellular $\beta$ Xylosidase of Termitomyces clypeatus. Biotechnology Progress, v. 13, n. 6, p. 822$827,1997$.

BIELY, P. et al. Endo- $\beta-1,4$-xylanase families: differences in catalytic properties. Journal of biotechnology, v. 57, n. 1, p. 151-166, 1997.

BIELY, P. et al. Trichoderma reesei XYN VI-a novel appendage-dependent eukaryotic glucuronoxylan hydrolase. FEBS Journal, v. 281, n. 17, p. 3894-3903, 2014.

BUNTERNGSOOK, B. et al. Binding characteristics and synergistic effects of bacterial expansins on cellulosic and hemicellulosic substrates. Bioresource technology, v. 176, p. 129-135, 2015. 
CANTAREL, B. L. et al. The Carbohydrate-Active EnZymes database (CAZy): an expert resource for glycogenomics. Nucleic acids research, v. 37, n. suppl 1, p. D233D238, 2009.

CARAPITO, R. et al. Efficient hydrolysis of hemicellulose by a Fusarium graminearum xylanase blend produced at high levels in Escherichia coli. Bioresource technology, v. 100, n. 2, p. 845-850, 2009.

CARVAlho, W.R. Produção e Purificação da Xilanase de 23 kDa do Fungo Termofílico Humicola grisea var. thermoidea. Faculdade de Engenharia Química de Lorena-SP. 2003., 2003.

CARVALHO, W. R. Caracterização bioquímica da endoxilanase recombinante (HXYN2r) do fungo termofílico Humicola grisea var. thermoidea e sua aplicação na sacarificação de resíduos agrícolas. Tese (Doutorado em Ciências da Saúde)Goiania, Goiás: Universidade Federal de Goiás, 30 jun. 2008.

CARVALLO, M. et al. Characterization of an $\alpha$-L-arabinofuranosidase gene (abf1) from Penicillium purpurogenum and its expression. Mycological research, v. 107, n. 4, p. 388-394, 2003.

CEREGHINO, J. L.; CREGG, J. M. Heterologous protein expression in the methylotrophic yeast Pichia pastoris. FEMS microbiology reviews, v. 24, n. 1, p. 45$66,2000$.

CHÁVEZ, R. et al. Differences in expression of two endoxylanase genes (xynA and xynB) from Penicillium purpurogenum. Gene, v. 293, n. 1, p. 161-168, 2002.

CHEN, F.; DIXON, R. A. Lignin modification improves fermentable sugar yields for biofuel production. Nat Biotech, v. 25, n. 7, p. 759-761, jul. 2007.

CHEN, H. et al. A comparison of several organosolv pretreatments for improving the enzymatic hydrolysis of wheat straw: Substrate digestibility, fermentability and structural features. Applied Energy, v. 150, p. 224-232, 15 jul. 2015. 
CHEN, Z. et al. Secretory expression of a $\beta$-xylosidase gene from Thermomyces lanuginosus in Escherichia coli and characterization of its recombinant enzyme. Letters in applied microbiology, v. 55, n. 5, p. 330-337, 2012.

CHOENGPANYA, K. et al. Cloning, expression and characterization of $\beta$-xylosidase from Aspergillus niger ASKU28. Protein expression and purification, v. 115, p. 132$140,2015$.

COLlinS, T.; GERDAY, C.; FELLER, G. Xylanases, xylanase families and extremophilic xylanases. FEMS Microbiology Reviews, v. 29, n. 1, p. 3-23, 1 jan. 2005.

COSGROVE, D. J. et al. The growing world of expansins. Plant and Cell Physiology, v. 43, n. 12, p. 1436-1444, 2002.

COS, O. et al. Combined effect of the methanol utilization (Mut) phenotype and gene dosage on recombinant protein production in Pichia pastoris fed-batch cultures. Journal of biotechnology, v. 116, n. 4, p. 321-335, 2005.

COS, O. et al. Operational strategies, monitoring and control of heterologous protein production in the methylotrophic yeast Pichia pastoris under different promoters: a review. Microbial cell factories, v. 5, n. 1, p. 1, 2006.

COSTA, T. H. et al. The enzymatic recalcitrance of internodes of sugar cane hybrids with contrasting lignin contents. Industrial Crops and Products, v. 51, p. 202-211, 2013.

COUGHLAN, M.; HAZLEWOOD, G. beta-1,4-D-xylan-degrading enzyme systems: biochemistry, molecular biology and applications. Biotechnology and Applied Biochemistry, v. 17, n. 3, p. 259-289, 1993.

CREGG, J. M. et al. Recombinant protein expression in Pichia pastoris. Molecular biotechnology, v. 16, n. 1, p. 23-52, 2000.

CRIPWELL, R. et al. Utilisation of wheat bran as a substrate for bioethanol production using recombinant cellulases and amylolytic yeast. Applied Energy, 2015. 
DAMASO, M. C.; ANDRADE, C. M.; PEREIRA JR, N. Use of corncob for endoxylanase production by thermophilic fungus Thermomyces lanuginosus IOC4145. Twenty-First Symposium on Biotechnology for Fuels and Chemicals. Anais...Springer, 2000Disponível em: <http://link.springer.com/10.1007/978-1-46121392-5_65>. Acesso em: 5 out. 2015

DAMASO, M. C. T. et al. Optimized expression of a thermostable xylanase from Thermomyces lanuginosus in Pichia pastoris. Applied and environmental microbiology, v. 69, n. 10, p. 6064-6072, 2003.

DE ALMEIDA, E. M. et al. Purification and biochemical characterization of $\beta$ xylosidase from Humicola grisea var. thermoidea. FEMS microbiology letters, v. 130, n. 2-3, p. 171-175, 1995.

DE ALMEIDA, M. N. et al. Cellulases and hemicellulases from endophytic Acremonium species and its application on sugarcane bagasse hydrolysis. Applied biochemistry and biotechnology, v. 165, n. 2, p. 594-610, 2011.

DE AZEVEDO, M. O. et al. Cloning, sequencing and homologies of the cbh-1 (exoglucanase) gene of Humicola grisea var. thermoidea. Journal of general microbiology, v. 136, n. 12, p. 2569-2576, 1990.

DE FARIA, F. P. et al. Expression and processing of a major xylanase (XYN2) from the thermophilic fungus Humicola grisea var. thermoidea in Trichoderma reesei. Letters in Applied Microbiology, v. 34, n. 2, p. 119-123, 2002.

DE FREITAS, S. M. et al. Structural Contributions for Thermostability of a New Endo1, 4- $\beta$-xylanase from the Fungus Humicola grisea. Internet Electronic Journal of Molecular Design, v. 2, p. 835-851, 2003.

DEKKER, R. F. H. Biodegradation of the Hetero-1,4-Linked Xylans. In: Plant Cell Wall Polymers. ACS Symposium Series. [s.1: s.n.]. v. 399p. Chapter 45, 619-629.

DE-PAULA, E. H.; RAMOS, L. P.; DE OLIVEIRA AZEVEDO, M. The potential of Humicola grisea var. thermoidea for bioconversion of sugar cane bagasse. Bioprocessing and Characterization of Lignocellulosics, v. 68, n. 1, p. 35-41, abr. 1999. 
DE PAULA, E.; POÇAS-FONSECA, M.; DE OLIVEIRA AZEVEDO, M. The product of Humicola grisea var. thermoidea cbh1.2 gene is the major expressed protein under induction by lignocellulosic residues. World Journal of Microbiology and Biotechnology, v. 19, n. 6, p. 631-635, 1 ago. 2003.

DE VRIES, R. P. et al. Synergy between enzymes from Aspergillus involved in the degradation of plant cell wall polysaccharides. Carbohydrate research, v. 327, n. 4, p. 401-410, 2000.

DE VRIES, R. P.; VISSER, J. Aspergillus enzymes involved in degradation of plant cell wall polysaccharides. Microbiology and molecular biology reviews, v. 65, n. 4, p. 497-522, 2001.

DILOKPIMOL, A. et al. Enzymatic synthesis of $\beta$-xylosyl-oligosaccharides by transxylosylation using two $\beta$-xylosidases of glycoside hydrolase family 3 from Aspergillus nidulans FGSC A4. Carbohydrate Research, v. 346, n. 3, p. 421-429, 15 fev. 2011.

DOTSENKO, G. S. et al. Heterologous $\beta$-glucosidase in a fungal cellulase system: comparison of different methods for development of multienzyme cocktails. Process Biochemistry, 2015.

DROUET, P.; ZHANG, M.; LEGOY, M. D. Enzymatic synthesis of alkyl $\beta$-Dxylosides by transxylosylation and reverse hydrolysis. Biotechnology and Bioengineering, v. 43, n. 11, p. 1075-1080, 1994.

DÜSTERHÖFT, E.-M. et al. Purification, characterization, and properties of two xylanases from Humicola insolens. Enzyme and Microbial Technology, v. 20, n. 6, p. 437-445, 1 maio 1997.

ERGÜN, B. G.; ÇALIK, P. Lignocellulose degrading extremozymes produced by Pichia pastoris: current status and future prospects. Bioprocess and biosystems engineering, v. 39, n. 1, p. 1-36, 2016.

FANG, H.; XIA, L. Cellulase production by recombinant Trichoderma reesei and its application in enzymatic hydrolysis of agricultural residues. Fuel, v. 143, p. 211-216, 2015. 
FELDMAN, D. Wood-chemistry, ultrastructure, reactions, by D. Fengel and G. Wegener, Walter de Gruyter, Berlin and New York, 1984, 613 pp. Price: 245 DM. Journal of Polymer Science: Polymer Letters Edition, v. 23, n. 11, p. 601-602, 1985.

FERREIRA FILHO. Purification and characterization of a beta-glucosidase from solidstate cultures of Humicola grisea var. thermoidea. Can J Microbiol. v. 42(1), p. 1-5, 1996.

FRITZ, M. et al. A family $51 \alpha$-1-arabinofuranosidase from Penicillium purpurogenum: purification, properties and amino acid sequence. Mycological Research, v. 112, n. 8, p. 933-942, ago. 2008.

FURTADO, A. et al. Modifying plants for biofuel and biomaterial production. Plant Biotechnology Journal, v. 12, n. 9, p. 1246-1258, 2014.

GÍRIO, F. M. et al. Hemicelluloses for fuel ethanol: A review. Special Issue on Lignocellulosic Bioethanol: Current Status and Perspectives, v. 101, n. 13, p. 47754800, jul. 2010.

GONÇALVES, G. A. et al. Synergistic effect and application of xylanases as accessory enzymes to enhance the hydrolysis of pretreated bagasse. Enzyme and microbial technology, v. 72, p. 16-24, 2015.

GONZALEZ-VOGEL, A. et al. Proteomic analysis in non-denaturing condition of the secretome reveals the presence of multienzyme complexes in Penicillium purpurogenum. Applied microbiology and biotechnology, v. 89, n. 1, p. 145-155, 2011.

GRACIANO, L. et al. The cloning, expression, purification, characterization and modeled structure of Caulobacter crescentus $\beta$-Xylosidase I. World Journal of Microbiology and Biotechnology, v. 28, n. 9, p. 2879-2888, 1 set. 2012.

GRAMANY, V. et al. Cloning, expression, and molecular dynamics simulations of a xylosidase obtained from Thermomyces lanuginosus. Journal of Biomolecular Structure and Dynamics, p. 1-12, 2015. 
HAN, Y.; CHEN, H. A $\beta$-xylosidase from cell wall of maize: purification, properties and its use in hydrolysis of plant cell wall. Journal of Molecular Catalysis B: Enzymatic, v. 63, n. 3, p. 135-140, 2010.

HENRISSAT, B.; DAVIES, G. Structural and sequence-based classification of glycoside hydrolases. Current Opinion in Structural Biology, v. 7, n. 5, p. 637-644, out. 1997.

HERRMANN, M. C. et al. The $\beta$-D-xylosidase of Trichoderma reesei is a multifunctional $\beta$-D-xylan xylohydrolase. Biochemical Journal, v. 321, n. 2, p. 375$381,1997$.

HOWARD, R. L. et al. Lignocellulose biotechnology: issues of bioconversion and enzyme production. African Journal of Biotechnology, v. 2, n. 12, p. 602-619, 2004.

HU, J. et al. The synergistic action of accessory enzymes enhances the hydrolytic potential of a "cellulase mixture" but is highly substrate specific. Biotechnol Biofuels, v. 6, n. 1, p. 112, 2013.

HU, J. et al. The Accessible Cellulose Surface Influences Cellulase Synergism during the Hydrolysis of Lignocellulosic Substrates. ChemSusChem, v. 8, n. 5, p. 901-907, 2015.

HU, J.; ARANTES, V.; SADDLER, J. N. The enhancement of enzymatic hydrolysis of lignocellulosic substrates by the addition of accessory enzymes such as xylanase: is it an additive or synergistic effect? Biotechnology for biofuels, v. 4, n. 1, p. 1-14, 2011.

HUY, N. D. et al. Cloning and characterization of a novel bifunctional acetyl xylan esterase with carbohydrate binding module from Phanerochaete chrysosporium. Journal of bioscience and bioengineering, v. 115, n. 5, p. 507-513, $2013 \mathrm{a}$.

HUY, N. D. et al. Characterization of a recombinant bifunctional xylosidase/arabinofuranosidase from Phanerochaete chrysosporium. Journal of Bioscience and Bioengineering, v. 116, n. 2, p. 152-159, ago. 2013 b. 
IEMBO, T. et al. Purification and partial characterization of a new $\beta$-xylosidase from Humicola grisea var. thermoidea. World Journal of Microbiology and Biotechnology, v. 22, n. 5, p. 475-479, 1 maio 2006.

ITO, T. et al. Xylosidases associated with the cell surface of Penicillium herquei IFO 4674. Journal of bioscience and bioengineering, v. 96, n. 4, p. 354-359, 2003.

JAIN, I.; KUMAR, V.; SATYANARAYANA, T. Applicability of recombinant $\beta$ xylosidase from the extremely thermophilic bacterium Geobacillus thermodenitrificans in synthesizing alkylxylosides. Bioresource technology, v. 170, p. 462-469, 2014.

JAMSHAD, M. et al. Structural characterization of recombinant human CD81 produced in Pichia pastoris. Protein expression and purification, v. 57, n. 2, p. 206-216, 2008.

JIANG, Z. B.; SONG, H. T.; MA, L. X. [Secreted expression of Bacillus pumilus xylanase gene in Pichia pastoris and study on enzymatic properties]. Sheng wu gong cheng xue bao= Chinese journal of biotechnology, v. 19, n. 1, p. 50-55, 2003.

JORDAN, D. B. et al. Structure-function relationships of a catalytically efficient $\beta$-Dxylosidase. Applied biochemistry and biotechnology, v. 141, n. 1, p. 51-76, 2007.

JORDAN, D. B. et al. Highly active $\beta$-xylosidases of glycoside hydrolase family 43 operating on natural and artificial substrates. Applied microbiology and biotechnology, v. 97, n. 10, p. 4415-4428, 2013.

JØRGENSEN, H.; OLSSON, L. Production of cellulases by Penicillium brasilianum IBT 20888-Effect of substrate on hydrolytic performance. Enzyme and Microbial Technology, v. 38, n. 3-4, p. 381-390, 1 fev. 2006.

JUTURU, V.; WU, J. C. Microbial xylanases: Engineering, production and industrial applications. Special issue on ACB 2011, v. 30, n. 6, p. 1219-1227, nov. 2012.

JUTURU, V.; WU, J. C. Heterologous expression of $\beta$-xylosidase gene from Paecilomyces thermophila in Pichia pastoris. World Journal of Microbiology and Biotechnology, v. 29, n. 2, p. 249-255, 2013.

JUTURU, V.; WU, J. C. Microbial cellulases: Engineering, production and applications. Renewable and Sustainable Energy Reviews, v. 33, p. 188-203, 2014. 
KHOO, H. H. Review of bio-conversion pathways of lignocellulose-to-ethanol: Sustainability assessment based on land footprint projections. Renewable and Sustainable Energy Reviews, v. 46, p. 100-119, jun. 2015.

KIRIKYALI, N.; CONNERTON, I. F. Heterologous expression and kinetic characterisation of Neurospora crassa $\beta$-xylosidase in Pichia pastoris. Enzyme and Microbial Technology, v. 57, p. 63-68, 10 abr. 2014.

KIRIKYALI, N.; CONNERTON, I. F. Xylan degrading enzymes from fungal sources. Journal of Proteomics \& Enzymology, v. 4, n. 1, p. 118, 2015.

KIRIKYALI, N.; WOOD, J.; CONNERTON, I. F. Characterisation of a recombinant $\beta$ xylosidase (xylA) from Aspergillus oryzae expressed in Pichia pastoris. AMB Express, v. 4, n. 1, p. 68, 2014.

KNOB, A.; TERRASAN, C. R. F.; CARMONA, E. C. $\beta$-Xylosidases from filamentous fungi: an overview. World Journal of Microbiology and Biotechnology, v. 26, n. 3, p. 389-407, 1 mar. 2010.

KORMELINK, F. J. M.; VORAGEN, A. G. J. Degradation of different [(glucurono) arabino] xylans by a combination of purified xylan-degrading enzymes. Applied microbiology and biotechnology, v. 38, n. 5, p. 688-695, 1993.

KOUSAR, S.; MUSTAFA, G.; JAMIL, A. Microbial Xylosidases: Production and Biochemical Characterization. life, v. 11, n. 2, p. 85-95, 2013.

KRACHER, D. et al. Fungal secretomes enhance sugar beet pulp hydrolysis. Biotechnology journal, v. 9, n. 4, p. 483-492, 2014.

KRAINER, F. W. et al. Recombinant protein expression in Pichia pastoris strains with an engineered methanol utilization pathway. Microbial cell factories, v. 11, n. 1, p. 1, 2012.

KROON, P. et al. Release of ferulic acid dehydrodimers from plant cell walls by feruloyl esterases. Journal of the Science of Food and Agriculture, v. 79, n. 3, p. 428-434, 1999. 
KULKARNI, N.; SHENDYE, A.; RAO, M. Molecular and biotechnological aspects of xylanases. FEMS Microbiology Reviews, v. 23, n. 4, p. 411-456, 1 jul. 1999.

KUMAR, V.; SHUKLA, P. Functional Aspects of Xylanases Toward Industrial Applications. In: Frontier Discoveries and Innovations in Interdisciplinary Microbiology. [s.1.] Springer, 2016. p. 157-165.

KURAKAKE, M. et al. Characteristics of transxylosylation by $\beta$-xylosidase from Aspergillus awamori K4. Biochimica et Biophysica Acta (BBA) - General Subjects, v. 1726, n. 3, p. 272-279, 30 nov. 2005.

KURTZMAN, C. P. Biotechnological strains of Komagataella (Pichia) pastoris are Komagataella phaffii as determined from multigene sequence analysis. Journal of industrial microbiology \& biotechnology, v. 36, n. 11, p. 1435-1438, 2009.

LAEMMLI, U. K. Cleavage of structural proteins during the assembly of the head of bacteriophage T4. nature, v. 227, p. 680-685, 1970.

LAGAERT, S. et al. $\beta$-Xylosidases and $\alpha$-l-arabinofuranosidases: Accessory enzymes for arabinoxylan degradation. Biotechnology Advances, v. 32, n. 2, p. 316-332, mar. 2014.

LAOTHANACHAREON, T. et al. Synergistic action of recombinant accessory hemicellulolytic and pectinolytic enzymes to Trichoderma reesei cellulase on rice straw degradation. Bioresource technology, v. 198, p. 682-690, 2015.

LAURUENGTANA, V.; PINPHANICHAKARN, P. Optimization of culture medium and conditions for $\alpha$-L-arabinofuranosidase production by Streptomyces sp. PC22. J Sci Res Chula Univ, v. 31, p. 57-66, 2006.

LEE, R. C. et al. Bifunctional Family 3 Glycoside Hydrolases from Barley with $\alpha-1-$ Arabinofuranosidase and $\beta$-d-Xylosidase Activity CHARACTERIZATION, PRIMARY STRUCTURES, AND COOH-TERMINAL PROCESSING. Journal of Biological Chemistry, v. 278, n. 7, p. 5377-5387, 2003. 
LENARTOVICZ, V. et al. Temperature and carbon source affect the production and secretion of a thermostable $\beta$-xylosidase by Aspergillus fumigatus. Process Biochemistry, v. 38, n. 12, p. 1775-1780, 31 jul. 2003.

LIAO, H. et al. Functional diversity and properties of multiple xylanases from Penicillium oxalicum GZ-2. Scientific reports, v. 5, 2015.

LI, J. et al. Cloning and optimized expression of a neutral endoglucanase gene (ncel5A) from Volvariella volvacea WX32 in Pichia pastoris. Journal of bioscience and bioengineering, v. 111, n. 5, p. 537-540, 2011.

LINEWEAVER, H.; BURK, D. The determination of enzyme dissociation constants. Journal of the American Chemical Society, v. 56, n. 3, p. 658-666, 1934.

LIU, Q. et al. Isolation of a novel cold-active family 11 xylanase from the filamentous fungus Bispora antennata and deletion of its $\mathrm{N}$-terminal amino acids on thermostability. Applied biochemistry and biotechnology, v. 175, n. 2, p. 925-936, 2015.

LI, Y. et al. High-level expression and characterization of a thermostable xylanase mutant from Trichoderma reesei in Pichia pastoris. Protein expression and purification, v. 108, p. 90-96, 2015.

LOOSER, V. et al. Cultivation strategies to enhance productivity of Pichia pastoris: A review. Biotechnology advances, v. 33, n. 6, p. 1177-1193, 2015.

LUCENA-NETO, S. DE A.; FERREIRA-FILHO, E. X. Purification and characterization of a new xylanase from Humicola grisea var. thermoidea. Brazilian Journal of Microbiology, v. 35, n. 1-2, p. 86-90, 2004.

LYND, L. R. et al. Microbial Cellulose Utilization: Fundamentals and Biotechnology. Microbiology and Molecular Biology Reviews, v. 66, n. 3, p. 506-577, set. 2002.

MACAULEY-PATRICK, S. et al. Heterologous protein production using the Pichia pastoris expression system. Yeast, v. 22, n. 4, p. 249-270, 2005.

MANDALARI, G. et al. Production of feruloyl esterases and xylanases by Talaromyces stipitatus and Humicola grisea var. thermoidea on industrial food processing by- 
products. Exploring Horizons in Biotechnology: A Global Venture, v. 99, n. 11, p. 5130-5133, jul. 2008.

MARCOLONGO, L. et al. The effect of Pleurotus ostreatus arabinofuranosidase and its evolved variant in lignocellulosic biomasses conversion. Fungal Genetics and Biology, v. 72, p. 162-167, 2014.

MARTÍNEZ, C. et al. Production of Rhodotorula glutinis: a yeast that secretes alpha-Larabinofuranosidase. Electronic Journal of Biotechnology, v. 9, n. 4, p. 0-0, 2006.

MCALliSTER, K. A.; MARRONE, L.; CLARKE, A. J. The role of tryptophan residues in substrate binding to catalytic domains $\mathrm{A}$ and $\mathrm{B}$ of xylanase $\mathrm{C}$ from Fibrobacter succinogenes S85. Biochimica et Biophysica Acta (BBA)-Protein Structure and Molecular Enzymology, v. 1480, n. 1, p. 342-352, 2000.

MELLITZER, A. et al. Expression of lignocellulolytic enzymes in Pichia pastoris. Microb Cell Fact, v. 11, n. 1, p. 61, 2012.

MICHELIN, M. et al. Purification and biochemical properties of multiple xylanases from Aspergillus ochraceus tolerant to $\mathrm{Hg} 2+$ ion and a wide range of $\mathrm{pH}$. Applied biochemistry and biotechnology, v. 174, n. 1, p. 206-220, 2014.

MILLER, G. L. Modified DNS method for reducing sugars. Anal. Chem, v. 31, n. 3, p. 426-428, 1959.

MINJIE, G. A. O.; ZHONGPING, S. H. I. Process control and optimization for heterologous protein production by methylotrophic Pichia pastoris. Chinese journal of chemical engineering, v. 21, n. 2, p. 216-226, 2013.

MORIYA, R. Y.; GONÇALVES, A. R.; FARIA, F. P. Enzymatic bleaching of organosolv sugarcane bagasse pulps with recombinant xylanase of the fungus Humicola grisea and with commercial cartazyme HS xylanase. Twenty-Sixth Symposium on Biotechnology for Fuels and Chemicals. Anais...Springer, 2005

MOSIER, N. et al. Features of promising technologies for pretreatment of lignocellulosic biomass. Bioresource Technology, v. 96, n. 6, p. 673-686, abr. 2005. 
MOUKOULI, M.; TOPAKAS, E.; CHRISTAKOPOULOS, P. Cloning and optimized expression of a GH-11 xylanase from Fusarium oxysporum in Pichia pastoris. New biotechnology, v. 28, n. 4, p. 369-374, 2011.

MUSTAFA, G. et al. Molecular cloning and comparative sequence analysis of fungal $\beta$ Xylosidases. AMB Express, v. 6, n. 1,p. 1-14, 2016.

NAVARRETE, M.; CALlEGARI, E.; EYZAGUIRRE, J. The effect of acetylated xylan and sugar beet pulp on the expression and secretion of enzymes by Penicillium purpurogenum. Applied microbiology and biotechnology, v. 93, n. 2, p. 723-741, 2012.

NAZIR, A. Review on Metagenomics and its Applications. Imperial Journal of Interdisciplinary Research, v. 2, n. 3, p. 277-286, 2016.

NIETO-DOMÍNGUEZ, $M$. et al. Characterization of a novel pH-stable GH3 $\beta$ xylosidase from Talaromyces amestolkiae: An enzyme displaying regioselective transxylosylation. Applied and environmental microbiology, p. AEM. 01744-15, $2015 \mathrm{a}$.

NIETO-DOMÍNGUEZ, M. et al. Novel pH-Stable Glycoside Hydrolase Family $3 \beta$ Xylosidase from Talaromyces amestolkiae: an Enzyme Displaying Regioselective Transxylosylation. Applied and environmental microbiology, v. 81, n. 18, p. 6380$6392,2015 b$.

NUMAN, M.; BHOSLE, N. $\alpha-1$-Arabinofuranosidases: the potential applications in biotechnology. Journal of Industrial Microbiology and Biotechnology, v. 33, n. 4, p. 247-260, 1 abr. 2006.

OLIVEIRA, G. S. et al. An alkaline thermostable recombinant Humicola grisea var. thermoidea cellobiohydrolase presents bifunctional (endo/exoglucanase) activity on cellulosic substrates. World Journal of Microbiology and Biotechnology, v. 29, n. 1, p. 19-26, 1 jan. 2013.

OLSSON, L. et al. Influence of the carbon source on production of cellulases, hemicellulases and pectinases by Trichoderma reesei Rut C-30. Enzyme and Microbial Technology, v. 33, n. 5, p. 612-619, 2003. 
PANAGIOTOU, G.; OLSSON, L. Effect of compounds released during pretreatment of wheat straw on microbial growth and enzymatic hydrolysis rates. Biotechnology and Bioengineering, v. 96, n. 2, p. 250-258, 2007.

PAN, I.-H.; YAO, H.-J.; LI, Y.-K. Effective extraction and purification of $\beta$-xylosidase from Trichoderma koningii fermentation culture by aqueous two-phase partitioning. Enzyme and Microbial Technology, v. 28, n. 2-3, p. 196-201, 1 fev. 2001.

PAPA, G. et al. Exploring the effect of different plant lignin content and composition on ionic liquid pretreatment efficiency and enzymatic saccharification of Eucalyptus globulus L. mutants. Bioresource Technology, v. 117, p. 352-359, ago. 2012.

PECIAROVÁ, A.; BIELY, P. $\beta$-xylosidases and a nonspecific wall-bound $\beta$ glucosidase of the yeast Cryptococcus albidus. Biochimica et Biophysica Acta (BBA) - General Subjects, v. 716, n. 3, p. 391-399, 16 jun. 1982.

PENGILLY, C. et al. Enzymatic hydrolysis of steam-pretreated sweet sorghum bagasse by combinations of cellulase and endo-xylanase. Fuel, v. 154, p. 352-360, 2015.

PERALTA, R. M. et al. A highly thermostable $\beta$-glucosidase activity from the thermophilic fungus Humicola grisea var. thermoidea: purification and biochemical characterization. FEMS Microbiology Letters, v. 146, n. 2, p. 291-295, 1997.

PÉREZ-FUENTES, C.; RAVANAL, M. C.; EYZAGUIRRE, J. Heterologous expression of a Penicillium purpurogenum pectin lyase in Pichia pastoris and its characterization. Fungal biology, v. 118, n. 5, p. 507-515, 2014.

PÉREZ, R.; EYZAGUIRRE, J. Aspergillus fumigatus Produces Two Arabinofuranosidases From Glycosyl Hydrolase Family 62: Comparative Properties of the Recombinant Enzymes. Applied biochemistry and biotechnology, p. 1-12, 2016.

POÇAS-FONSECA, M. J. et al. Substrate-dependent differential expression of Humicola grisea var. thermoidea cellobiohydrolase genes. Canadian journal of microbiology, v. 46, n. 8, p. 749-752, 2000. 
POLIZELI, M. L. T. M. et al. Xylanases from fungi: properties and industrial applications. Applied Microbiology and Biotechnology, v. 67, n. 5, p. 577-591, 1 jun. 2005.

QING, Q.; WYMAN, C. E. Supplementation with xylanase and $\beta$-xylosidase to reduce xylo-oligomer and xylan inhibition of enzymatic hydrolysis of cellulose and pretreated corn stover. Biotechnology for Biofuels, v. 4, n. 1, p. 1, 2011.

QING, Q.; YANG, B.; WYMAN, C. E. Xylooligomers are strong inhibitors of cellulose hydrolysis by enzymes. Bioresource technology, v. 101, n. 24, p. 9624-9630, 2010.

RAHMAN, A. S. et al. A role of xylanase, $\alpha$-L-arabinofuranosidase, and xylosidase in xylan degradation. Canadian journal of microbiology, v. 49, n. 1, p. 58-64, 2003.

RAMOS, G. P. Produção de celulas e xilanases pelo fungo termofílio Humicola grisea var. thermoidea em diferentes substratos lignocelulósicos. DissertaçãoGoiânia, Goiás: Universidade Federal de Goiás, Ago 2010.

RATANAKHANOKCHAI, K. et al. Paenibacillus curdlanolyticus strain B-6 multienzyme complex: A novel system for biomass utilization. Biomass NowCultivation and Utilization, 2013.

RAVANAL, M. C. et al. Penicillium purpurogenum produces two GH family 43 enzymes with $\beta$-xylosidase activity, one monofunctional and the other bifunctional: Biochemical and structural analyses explain the difference. Archives of Biochemistry and Biophysics, v. 540, n. 1-2, p. 117-124, dez. 2013.

RAVANAL, M. C.; CALLEGARI, E.; EYZAGUIRRE, J. Novel Bifunctional $\alpha-1-$ Arabinofuranosidase/Xylobiohydrolase (ABF3) from Penicillium purpurogenum. Applied and Environmental Microbiology, v. 76, n. 15, p. 5247-5253, ago. 2010.

RAVANAL, M. C.; EYZAGUIRRE, J. Heterologous expression and characterization of $\alpha$-l-arabinofuranosidase 4 from Penicillium purpurogenum and comparison with the other isoenzymes produced by the fungus. Fungal Biology, v. 119, n. 7, p. 641-647, jul. 2015. 
RAWEESRI， P.; RIANGRUNGROJANA， P.; PINPHANICHAKARN， P. $\alpha-1-$ Arabinofuranosidase from Streptomyces sp. PC22: Purification, characterization and its synergistic action with xylanolytic enzymes in the degradation of xylan and agricultural residues. Bioresource Technology, v. 99, n. 18, p. 8981-8986, dez. 2008.

REDDY, S. S.; KRISHNAN, C. Production of high-pure xylooligosaccharides from sugarcane bagasse using crude $\beta$-xylosidase-free xylanase of Bacillus subtilis KCX006 and their bifidogenic function. LWT - Food Science and Technology, In Press, Accepted Manuscript 2015.

REZENDE, C. A. et al. Chemical and morphological characterization of sugarcane bagasse submitted to a delignification process for enhanced enzymatic digestibility. Biotechnology for biofuels, v. 4, n. 1, p. 1-19, 2011.

ROCHA, G. J. DE M. et al. Influence of mixed sugarcane bagasse samples evaluated by elemental and physical-chemical composition. Industrial Crops and Products, v. 64, p. 52-58, fev. 2015.

RUBINELLI, P. M. et al. Constitutive expression of the Corngrass1 microRNA in poplar affects plant architecture and stem lignin content and composition. Biomass and Bioenergy, v. 54, p. 312-321, jul. 2013.

RUBINI, M. R. et al. Cloning, characterization and heterologous expression of the first Penicillium echinulatum cellulase gene. Journal of applied microbiology, v. 108, n. 4, p. 1187-1198, 2010.

SAHA, B. C. $\alpha$-l-Arabinofuranosidases: biochemistry, molecular biology and application in biotechnology. Biotechnology Advances, v. 18, n. 5, p. 403-423, ago. 2000.

SAHA, B. C. Purification and properties of an extracellular $\beta$-xylosidase from a newly isolated Fusarium proliferatum. Bioresource technology, v. 90, n. 1, p. 33-38, 2003.

SAHA, B. C.; BOTHAST, R. J. Effect of carbon source on production of $\alpha$-Larabinofuranosidase by Aureobasidium pullulans. Current microbiology, v. 37, n. 5, p. 337-340, 1998. 
SAITOU, N.; NEI, M. The neighbor-joining method: a new method for reconstructing phylogenetic trees. Molecular biology and evolution, v. 4, n. 4, p. 406-425, 1987.

SAKKA, K. et al. Nucleotide Sequence of the Clostridium stercorarium xylA Gene Encoding a Bifunctional Protein with $\beta$-D-Xylosidase and $\alpha$-L-Arabinofuranosidase Activities, and Properties of the Translated Product. Bioscience, Biotechnology, and Biochemistry, v. 57, n. 2, p. 268-272, 1993.

SAMBROOK, J. R.; RUSSEL, D. W. DW 2001. Molecular Cloning: A Laboratory Manual, [s.d.].

SAMBROOK, J.; RUSSELL, D. W.; RUSSELL, D. W. The condensed protocols from molecular cloning: a laboratory manual. [s.1.] Cold Spring Harbor Laboratory Press Cold Spring Harbor, NY, 2006.

SÁNCHEZ, C. Lignocellulosic residues: Biodegradation and bioconversion by fungi. Biotechnology Advances, v. 27, n. 2, p. 185-194, mar. 2009.

SELIG, M. J. et al. Synergistic enhancement of cellobiohydrolase performance on pretreated corn stover by addition of xylanase and esterase activities. Bioresource Technology, v. 99, n. 11, p. 4997-5005, 2008.

SEMENOVA, M. V. et al. Isolation and properties of extracellular $\beta$-xylosidases from fungi Aspergillus japonicus and Trichoderma reesei. Biochemistry (Moscow), v. 74, n. 9, p. 1002-1008, 2009.

SHARMA, A. et al. Cellulases: Classification, Methods of Determination and Industrial Applications. Applied Biochemistry and Biotechnology, p. 1-35, 2016 a.

SHARMA, M. et al. Profiling and production of hemicellulases by thermophilic fungus Malbranchea flava and the role of xylanases in improved bioconversion of pretreated lignocellulosics to ethanol. 3 Biotech, v. 6, n. 1, p. 1-12, $2016 \mathrm{~b}$.

SHARMA, S.; VAID, S.; BAJAJ, B. J. Screening of thermo-alkali stable fungal xylanases for potential industrial applications. Current Research in Microbiology and Biotechnology, v. 3, n. 1, p. 536-541, 2015. 
SHI, H. et al. Biochemical properties of a novel thermostable and highly xylose-tolerant $\beta$-xylosidase/ $\alpha$-arabinosidase from Thermotoga thermarum. Biotechnology for biofuels, v. 6, n. 1, p. 1, 2013.

SHINOZAKI, A. et al. A novel GH43 $\alpha$-1-arabinofuranosidase of Penicillium chrysogenum that preferentially degrades single-substituted arabinosyl side chains in arabinan. Enzyme and Microbial Technology, v. 58-59, p. 80-86, 10 maio 2014.

SHI, P. et al. Gene cloning, expression, and characterization of a family $51 \alpha-1-$ arabinofuranosidase from Streptomyces sp. S9. Applied biochemistry and biotechnology, v. 162, n. 3, p. 707-718, 2010.

SHI, P. et al. Molecular characterization of a new alkaline-tolerant xylanase from Humicola insolens Y1. BioMed research international, v. 2015, 2015.

SIMMONS, B. A.; LOQUÉ, D.; RALPH, J. Advances in modifying lignin for enhanced biofuel production. Current Opinion in Plant Biology, v. 13, n. 3, p. 312-319, jun. 2010.

SIQUEIRA, F. G.; FILHO, E. X. F. Plant Cell Wall as a Substrate for the Production of Enzymes with Industrial Applications. Mini-Reviews in Organic Chemistry, v. 7, n. 1, p. $54-60,2010$.

SOUZA, F. H. M. et al. Gene cloning, expression and biochemical characterization of a glucose-and xylose-stimulated $\beta$-glucosidase from Humicola insolens RP86. Journal of Molecular Catalysis B: Enzymatic, v. 106, p. 1-10, 2014.

SPOHNER, S. C. et al. Expression of enzymes for the usage in food and feed industry with Pichia pastoris. Journal of biotechnology, v. 202, p. 118-134, 2015.

SREEDHARAN, S. et al. An Overview on Fungal Cellulases with an Industrial Perspective. Journal of Nutrition \& Food Sciences, v. 2016, 2016.

STUDER, M. H. et al. Lignin content in natural Populus variants affects sugar release. Proceedings of the National Academy of Sciences, v. 108, n. 15, p. 6300-6305, 2011. 
SULISTYO, J.; KAMIYAMA, Y.; YASUI, T. Purification and some properties of Aspergillus pulverulentus $\beta$-xylosidase with transxylosylation capacity. Journal of Fermentation and Bioengineering, v. 79, n. 1, p. 17-22, 1995.

SUN, F. F. et al. Accessory enzymes influence cellulase hydrolysis of the model substrate and the realistic lignocellulosic biomass. Enzyme and Microbial Technology, v. 79, p. 42-48, 2015.

SUN, X.-F. et al. Extraction and characterization of original lignin and hemicelluloses from wheat straw. Journal of agricultural and food chemistry, v. 53, n. 4, p. 860$870,2005$.

SUZUKI, S. et al. Characterization of Aspergillus oryzae glycoside hydrolase family 43 $\beta$-xylosidase expressed in Escherichia coli. Journal of Bioscience and Bioengineering, v. 109, n. 2, p. 115-117, fev. 2010.

TAKASHIMA, S. et al. Cloning, sequencing, and expression of the cellulase genes of Humicola grisea var. thermoidea. Journal of Biotechnology, v. 50, n. 2-3, p. 137-147, 1 out. 1996.

TAKASHIMA, S. et al. Molecular cloning and expression of the novel fungal $\beta$ glucosidase genes from Humicola grisea and Trichoderma reesei. Journal of Biochemistry, v. 125, n. 4, p. 728-736, 1999a.

TAKASHIMA, S. et al. Comparison of gene structures and enzymatic properties between two endoglucanases from Humicola grisea. Journal of Biotechnology, v. 67, n. 2-3, p. 85-97, 22 jan. 1999b.

TAO, L. et al. Process and technoeconomic analysis of leading pretreatment technologies for lignocellulosic ethanol production using switchgrass. Bioresource Technology, v. 102, n. 24, p. 11105-11114, dez. 2011.

TENG, C. et al. High-level expression of extracellular secretion of a $\beta$-xylosidase gene from Paecilomyces thermophila in Escherichia coli. Bioresource Technology, v. 102, n. 2, p. 1822-1830, jan. 2011. 
TORRES, F. A. E. et al. Natural colorants from filamentous fungi. Applied microbiology and biotechnology, p. 1-11, 2016.

UTT, E. A. et al. Sequencing and expression of the Butyrivibrio fibrisolvens xylB gene encoding a novel bifunctional protein with beta-D-xylosidase and alpha-Larabinofuranosidase activities. Applied and Environmental Microbiology, v. 57, n. 4 , p. 1227-1234, abr. 1991.

VAN DEN BRINK, J.; DE VRIES, R. P. Fungal enzyme sets for plant polysaccharide degradation. Applied microbiology and biotechnology, v. 91, n. 6, p. 1477-1492, 2011.

VAN DYK, J. S.; PLETSCHKE, B. I. A review of lignocellulose bioconversion using enzymatic hydrolysis and synergistic cooperation between enzymes -Factors affecting enzymes, conversion and synergy. Special issue on ACB 2011, v. 30, n. 6, p. 14581480, nov. 2012.

VÁRNAI, A. et al. Effects of enzymatic removal of plant cell wall acylation (acetylation, p-coumaroylation, and feruloylation) on accessibility of cellulose and xylan in natural (non-pretreated) sugar cane fractions. Biotechnology for biofuels, v. 7, n. 1,p. 1, 2014.

VIBORG, A. H. et al. Biochemical and kinetic characterisation of a novel xylooligosaccharide-upregulated $\quad$ GH43 $\beta$-D-xylosidase/ $\alpha$-L-arabinofuranosidase (BXA43) from the probiotic Bifidobacterium animalis subsp. lactis BB-12. AMB Express, v. 3, n. 1, p. 56, 2013.

WAEONUKUL, R. et al. Effect of carbon sources on the induction of xylanolyticcellulolytic multienzyme complexes in Paenibacillus curdlanolyticus strain B-6. Bioscience, biotechnology, and biochemistry, v. 72, n. 2, p. 321-328, 2008.

WAKIYAMA, M. et al. Purification and properties of an extracellular $\beta$-xylosidase from Aspergillus japonicus and sequence analysis of the encoding gene. Journal of bioscience and bioengineering, v. 106, n. 4, p. 398-404, 2008. 
WAN, C.-F. et al. Expression, Purification and Characterization of a Bifunctional $\alpha-\mathrm{L}-$ Arabinofuranosidase/ $\beta$-D-Xylosidase from Trichoderma Koningii G-39. Journal of the Chinese Chemical Society, v. 54, n. 1, p. 109-116, 2007.

WANG, J.; LI, Y.; LIU, D. Improved Production of Aspergillus usamii endo- $\beta-1,4-$ Xylanase in Pichia pastoris via Combined Strategies. BioMed Research International, v. 2016, 2016.

WILKENS, C. et al. An efficient arabinoxylan-debranching $\alpha$-l-arabinofuranosidase of family GH62 from Aspergillus nidulans contains a secondary carbohydrate binding site. Applied microbiology and biotechnology, p. 1-13, 2016.

WONGWISANSRI, S. et al. High-level production of thermotolerant $\beta$-xylosidase of Aspergillus sp. BCC125 in Pichia pastoris: Characterization and its application in ethanol production. Bioresource technology, v. 132, p. 410-413, 2013.

XIA, W. et al. High Level Expression of a Novel Family 3 Neutral $\beta$-Xylosidase from Humicola insolens Y1 with High Tolerance to D-Xylose. PLoS ONE, v. 10, n. 2, p. $\mathrm{e} 0117578,2015$.

XIMENES, F. DE A.; DE PAULA SILVEIRA, F. Q.; F FILHO, E. X. Production of $\beta$ Xylosidase Activity by Trichoderma harzianum Strains. Current microbiology, v. 33, n. 2, p. 71-77, 1996.

$\mathrm{XU}, \mathrm{Z}$. et al. Functional genomic analysis of Arabidopsis thaliana glycoside hydrolase family 1. Plant molecular biology, v. 55, n. 3, p. 343-367, 2004.

XU, Z.; SHIH, M.-C.; POULTON, J. E. An extracellular exo- $\beta-(1,3)$-glucanase from Pichia pastoris: purification, characterization, molecular cloning, and functional expression. Protein expression and purification, v. 47, n. 1, p. 118-127, 2006.

YANG, J.; ZHOU, X.; ZHANG, Y. Improvement of recombinant hirudin production by controlling NH4+ concentration in Pichia pastoris fermentation. Biotechnology letters, v. 26, n. 12, p. 1013-1017, 2004. 
YANG, X. et al. Two xylose-tolerant GH43 bifunctional $\beta$-xylosidase $/ \alpha$-arabinosidases and one GH11 xylanase from Humicola insolens and their synergy in the degradation of xylan. Food Chemistry, v. 148, p. 381-387, 1 abr. 2014.

YANG, X. et al. A New GH43 $\alpha$-Arabinofuranosidase from Humicola insolens Y1: Biochemical Characterization and Synergistic Action with a Xylanase on Xylan Degradation. Applied Biochemistry and Biotechnology, v. 175, n. 4, p. 1960-1970, 1 fev. 2015.

YAN, Q. et al. Purification and characterization of a novel thermostable $\alpha-1$ arabinofuranosidase ( $\alpha$-l-AFase) from Chaetomium sp. Biomass-derived pentoses, $v$. 47, n. 3, p. 472-478, mar. 2012.

YAN, Q. J. et al. A xylose-tolerant $\beta$-xylosidase from Paecilomyces thermophila: Characterization and its co-action with the endogenous xylanase. Bioresource Technology, v. 99, n. 13, p. 5402-5410, set. 2008.

YU, Y. et al. High-yield production of the human lysozyme by Pichia pastoris SMD1168 using response surface methodology and high-cell-density fermentation. Electronic Journal of Biotechnology, v. 17, n. 6, p. 311-316, 2014.

ZHANG, J. et al. Thermostable recombinant xylanases from Nonomuraea flexuosa and Thermoascus aurantiacus show distinct properties in the hydrolysis of xylans and pretreated wheat straw. Biotechnology for biofuels, v. 4, n. 1, p. 12, $2011 \mathrm{a}$.

ZHANG, J. et al. Comparison of the synergistic action of two thermostable xylanases from GH families 10 and 11 with thermostable cellulases in lignocellulose hydrolysis. Bioresource technology, v. 102, n. 19, p. 9090-9095, 2011 b.

ZHANG, J.; TANG, M.; VIIKARI, L. Xylans inhibit enzymatic hydrolysis of lignocellulosic materials by cellulases. Bioresource technology, v. 121, p. 8-12, 2012.

ZHANG, S. et al. Cloning, expression, and characterization of a thermostable $\beta$ xylosidase from thermoacidophilic Alicyclobacillus sp. A4. Process Biochemistry, v. 49, n. 9, p. 1422-1428, 2014. 
ZHANG, S.-B. et al. Expression of feruloyl esterase A from Aspergillus terreus and its application in biomass degradation. Protein Expression and Purification, 2015.

ZHONG, C. et al. Selective hydrolysis of hemicellulose from wheat straw by a nanoscale solid acid catalyst. Carbohydrate Polymers, v. 131, p. 384-391, 20 out. 2015. 